NATIONAL LABORATORY

\title{
A Review of Barriers to and Opportunities for the Integration of Renewable Energy in the Southeast
}

May 2011

Prepared by

Ben W. McConnell Stanton W. Hadley Yan Xu

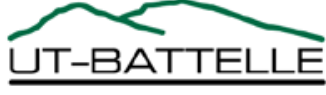




\title{
DOCUMENT AVAILABILITY
}

Reports produced after January 1, 1996, are generally available free via the U.S. Department of Energy (DOE) Information Bridge.

Web site http://www.osti.gov/bridge

Reports produced before January 1, 1996, may be purchased by members of the public from the following source.

\author{
National Technical Information Service \\ 5285 Port Royal Road \\ Springfield, VA 22161 \\ Telephone 703-605-6000 (1-800-553-6847) \\ TDD 703-487-4639 \\ Fax 703-605-6900 \\ E-mail info@ntis.gov \\ Web site http://www.ntis.gov/support/ordernowabout.htm
}

Reports are available to DOE employees, DOE contractors, Energy Technology Data Exchange (ETDE) representatives, and International Nuclear Information System (INIS) representatives from the following source.

Office of Scientific and Technical Information

P.O. Box 62

Oak Ridge, TN 37831

Telephone 865-576-8401

Fax 865-576-5728

E-mail reports@osti.gov

Web site http://www.osti.gov/contact.html

This report was prepared as an account of work sponsored by an agency of the United States Government. Neither the United States Government nor any agency thereof, nor any of their employees, makes any warranty, express or implied, or assumes any legal liability or responsibility for the accuracy, completeness, or usefulness of any information, apparatus, product, or process disclosed, or represents that its use would not infringe privately owned rights. Reference herein to any specific commercial product, process, or service by trade name, trademark, manufacturer, or otherwise, does not necessarily constitute or imply its endorsement, recommendation, or favoring by the United States Government or any agency thereof. The views and opinions of authors expressed herein do not necessarily state or reflect those of the United States Government or any agency thereof. 


\title{
A REVIEW OF BARRIERS TO AND OPPORTUNITIES FOR THE INTEGRATION OF RENEWABLE ENERGY IN THE SOUTHEAST
}

\author{
Ben W. McConnell \\ Stanton W. Hadley \\ $\mathrm{Yan} \mathrm{Xu}$
}

Date Published: May 2011

\author{
Prepared by \\ OAK RIDGE NATIONAL LABORATORY \\ Oak Ridge, Tennessee 37831-6283 \\ managed by \\ UT-BATTELLE, LLC \\ for the \\ U.S. DEPARTMENT OF ENERGY \\ under contract DE-AC05-00OR22725
}





\section{CONTENTS}

Page

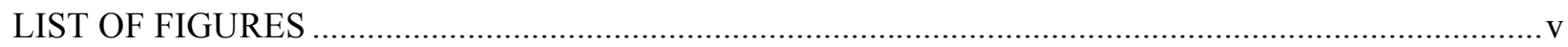

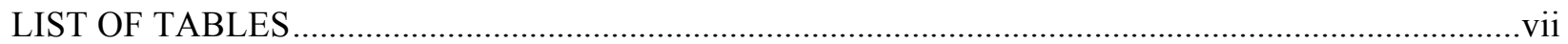

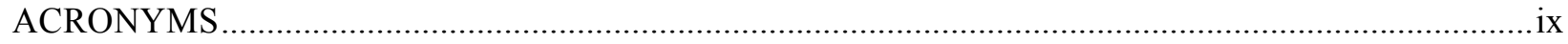

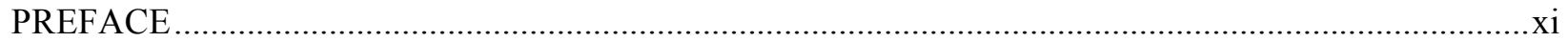

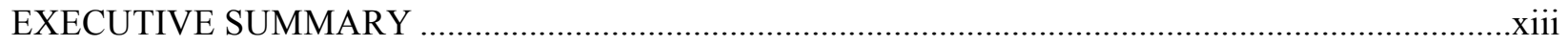

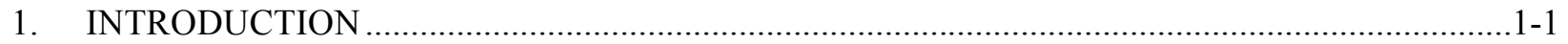

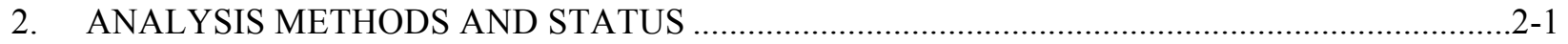

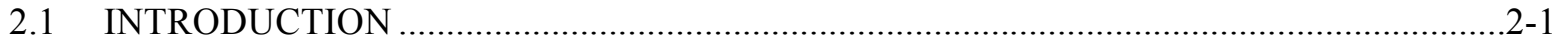

2.2 MEETING LOAD GROWTH WITH DIVERSE RESOURCES .......................................

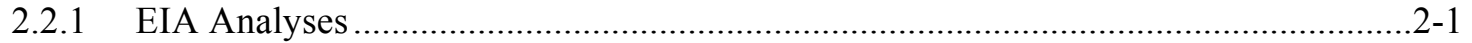

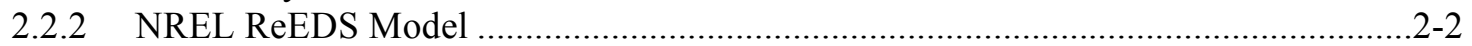

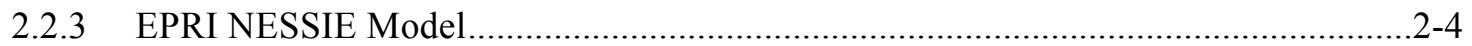

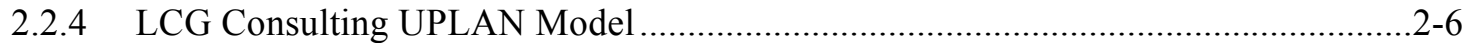

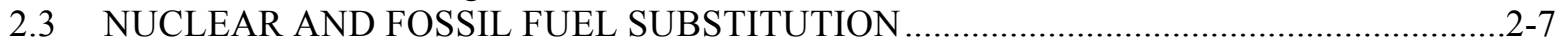

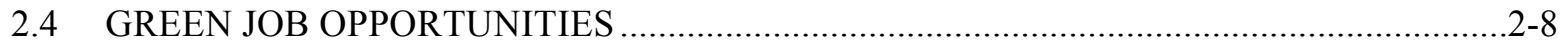

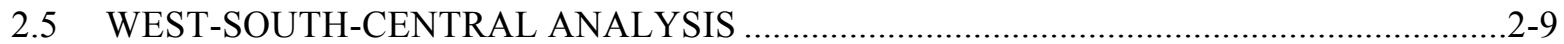

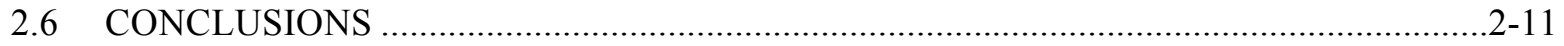

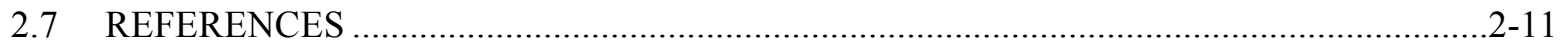

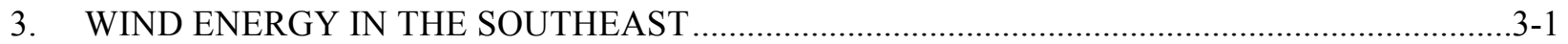

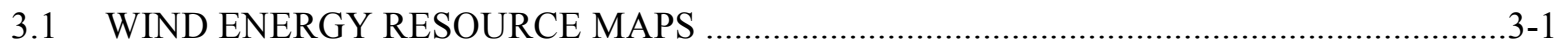

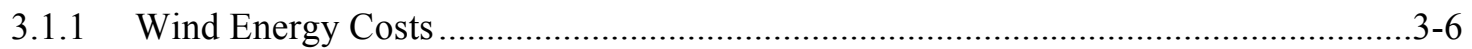

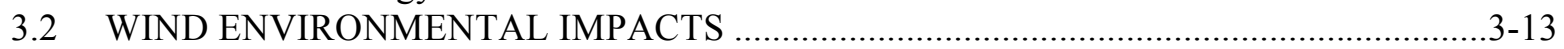

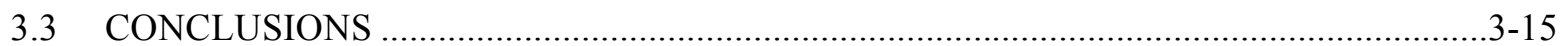

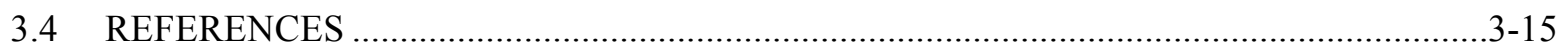

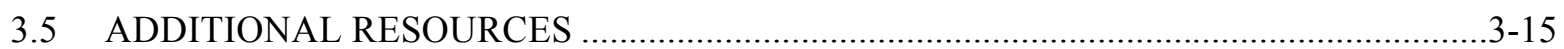

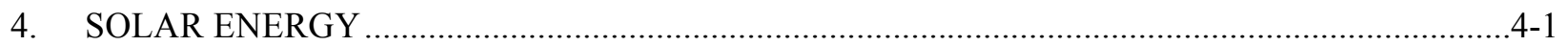

4.1 NONELECTRICAL APPLICATIONS OF SOLAR TECHNOLOGY .............................4-1

4.1.1 Passive Solar Technology ......................................................................................

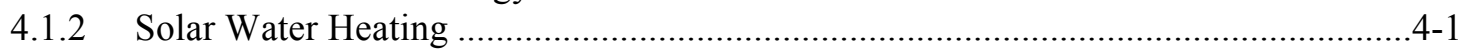

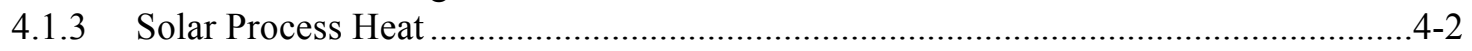

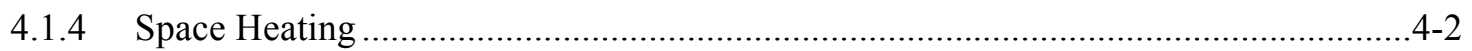

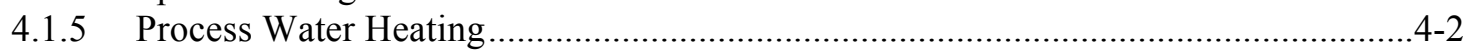

4.1.6 Space Cooling .......................................................................................................... $4-2$

4.2 ELECTRICITY-GENERATING APPLICATIONS OF SOLAR ENERGY ..........................4-2

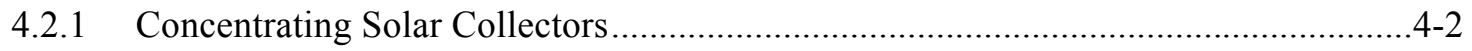

4.2.2 Solar Photovoltaic Technology .........................................................................

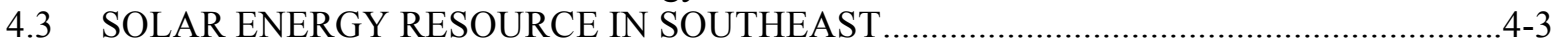

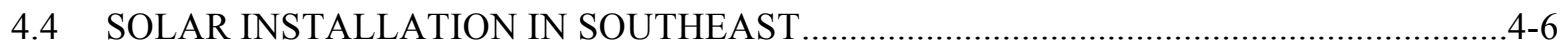

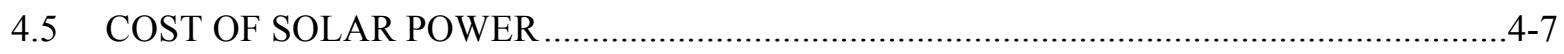

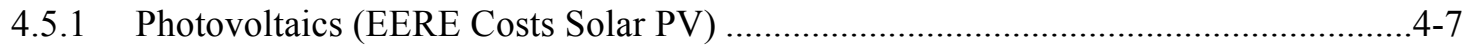

4.5.2 Thermal Concentrators (EERE Costs Solar Concentrators) ........................................4-8

4.6 SOLAR ENVIRONMENTAL IMPACTS (UCS CLEAN ENERGY TECHNOLOGY)......4-10

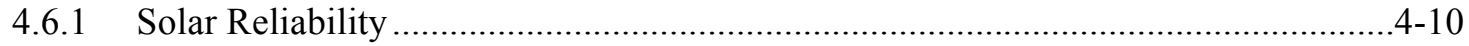

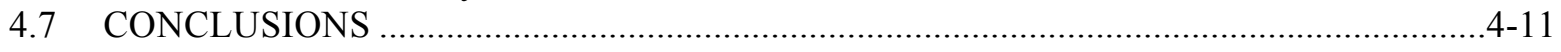

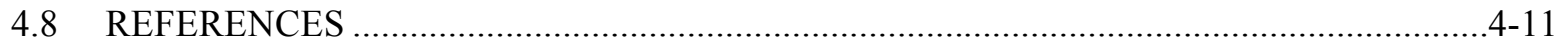

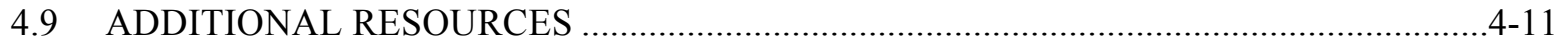




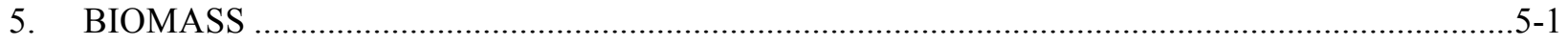

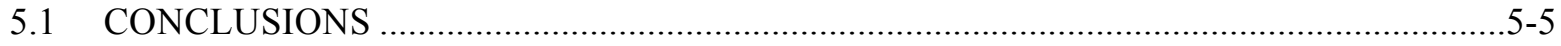

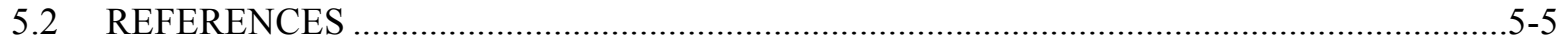

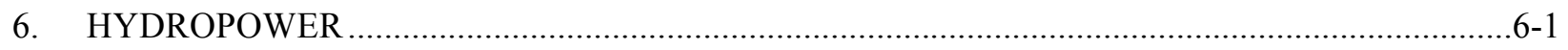

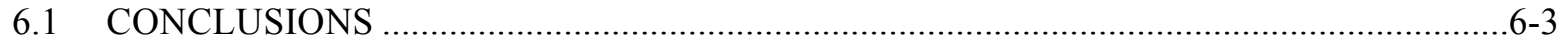

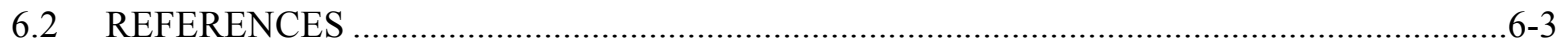

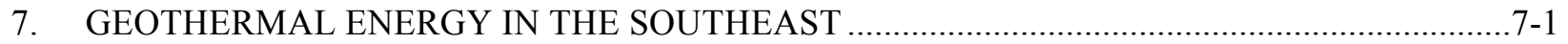

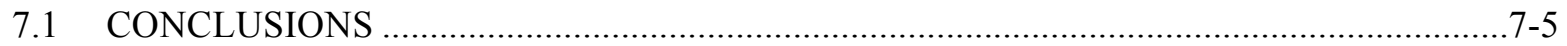

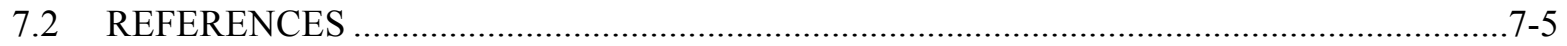

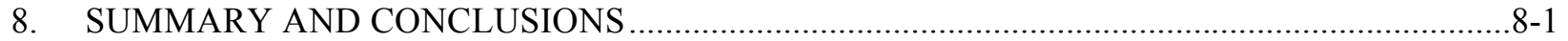

8.1 MODELING AND INTEGRATION STUDIES ..........................................................

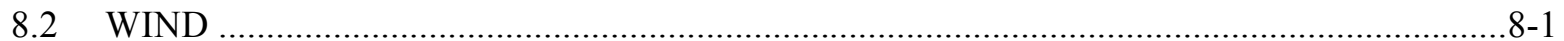

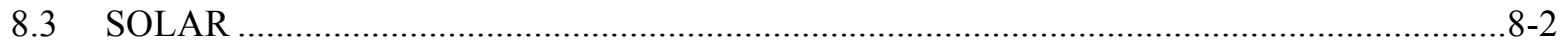

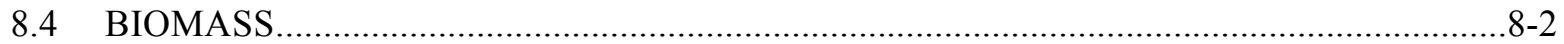

8.5 HYDRO …

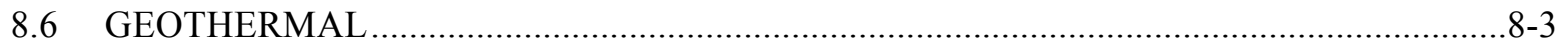

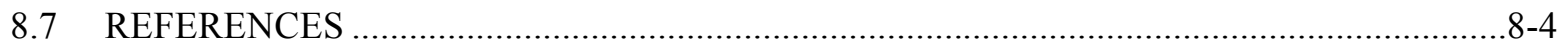

APPENDIX A. ONSHORE AND OFFSHORE WIND POWER POTENTIAL ..................................A-1

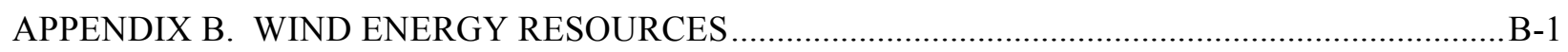

APPENDIX C. SOLAR MANUFACTURING IN SOUTHEAST ….....................................................

APPENDIX D. SOLAR ENERGY MARKET AND RESOURCE CENTERS IN THE

SOUTHEAST (NREL SOLAR CALCULATORS) …................................................................. 


\section{LIST OF FIGURES}

ES.1 Regional variation in renewable generation, RPS policy case (2020) ...................................

ES.2 Potential and developed hydro for the expanded Southeast region ........................................iii

$2.1 \quad$ Thirteen NERC regions used in NEMS and other models...............................................2-2

2.2 Regional variation in renewable generation, RPS policy case (2020) .................................

2.3 NESSIE distribution of selected resources in the Southeast ...........................................2-5

2.4 SERC generation with no policy or federal RPS or federal climate policy .........................2-6

2.5 UPLAN estimate of 2020 capacities in SERC (GW) ..................................................2-6

2.6 Generation in 2030 for SERC and FRCC under different NEMS scenarios (TWhr) ...........2-8

2.7 Generation in 2030 for ERCOT and SPP under different NEMS scenarios (TWhr) ...........2-10

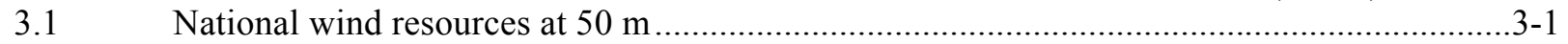

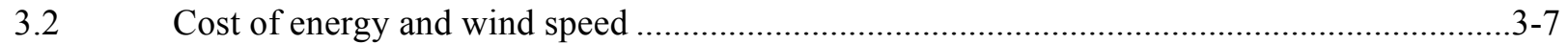

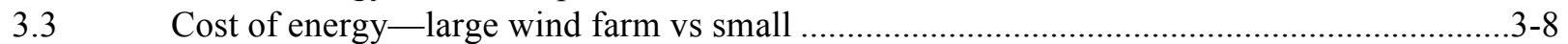

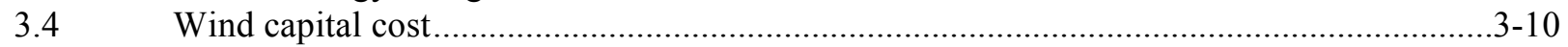

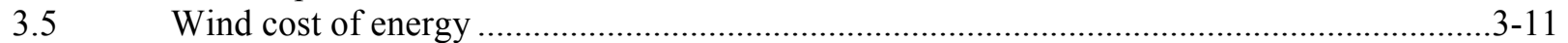

3.6 Wind energy price by commercial operation date (COD) using 2006 data.........................3-12

3.7 Operation and maintenance costs for large-scale wind plants installed within the last

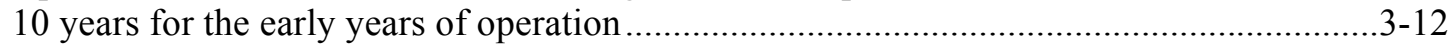

4.1 National solar photovoltaics resource potential map of United States ................................4-4

4.2 National concentrating solar resource map of United States .............................................4-5

4.3 PV efficiency, capital, and energy cost projections for classic solar PV materials ...............4-9

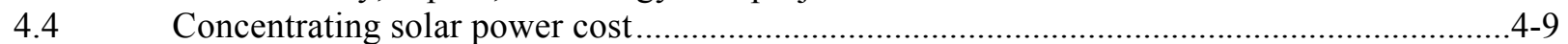

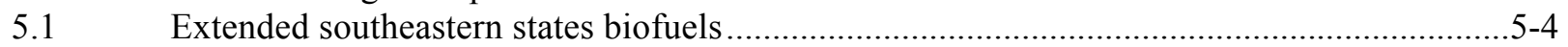

5.2 Extended southeastern states biofuels resource potential for generation in terawatt-

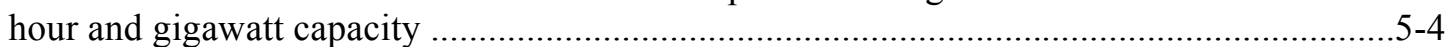

6.1 Potential and developed hydro for expanded Southeast region .........................................6-2

6.2 Percent hydro developed by state in expanded Southeast region .......................................6-2

7.1 Total megawatts-electrical potential at drill depth for $10 \%$ recovery factor. Adapted from MIT (2008) ....................................................................................................

7.2 Total megawatts-electrical potential by state for $10 \%$ recovery factor............................... $7-3$

A.1 Alabama annual average wind speed at $80 \mathrm{~m}$................................................................ -5

A.2 Alabama wind resource potential: Cumulative rated capacity vs gross capacity

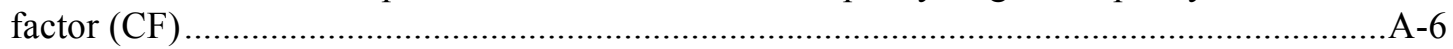

A.3 Arkansas annual average wind speed at 80-meter .........................................................

A.4 Arkansas wind resource potential: Cumulative rated capacity vs gross capacity

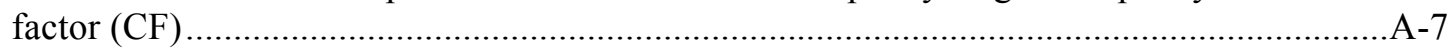

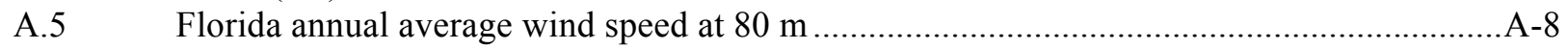

A.6 Florida wind resource potential: cumulative rated capacity vs gross capacity

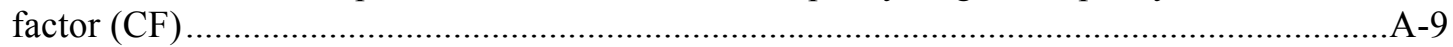

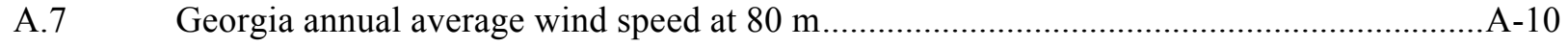

A.8 Wind resource of Georgia offshore mean annual wind speed at $90 \mathrm{~m}$.............................A-11

A.9 Georgia wind resource potential: Cumulative rated capacity vs gross capacity

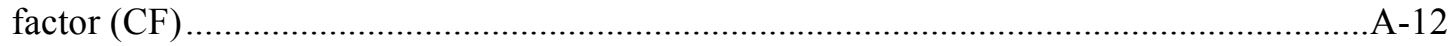

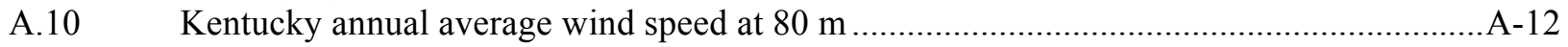

A.11 Kentucky wind resource potential: Cumulative rated capacity vs gross capacity

factor $(\mathrm{CF})$... 
A.12 (a) Louisiana annual average wind speed at $80 \mathrm{~m}$ and (b) Louisiana offshore wind resource at $90 \mathrm{~m}$ hub height

A.13 Louisiana wind resource potential: Cumulative rated capacity vs gross capacity

factor $(\mathrm{CF})$

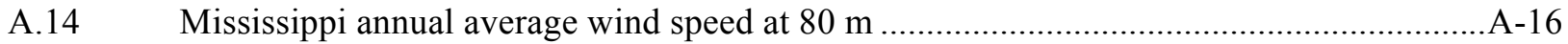

A.15 Mississippi wind resource potential: Cumulative rated capacity vs gross capacity factor $(\mathrm{CF})$

A.16 Missouri wind map shows the wind resource at 80 meters...............................................17

A.17 Missouri wind resource potential: Cumulative rated capacity vs gross capacity factor $(\mathrm{CF})$

A.18 North Carolina annual average wind speed at $80 \mathrm{~m}$...................................................19

A.19 North Carolina annual average offshore wind speed at $90 \mathrm{~m}$ hub height ............................20

A.20 North Carolina wind resource potential: Cumulative rated capacity vs gross capacity factor (CF)

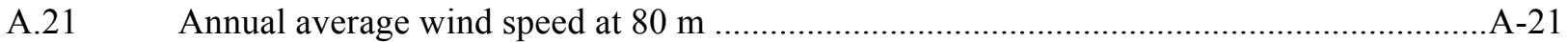

A.22 Oklahoma wind resource potential: Cumulative rated capacity vs gross capacity factor $(\mathrm{Cf})$

A.31 (a) Virginia annual average wind speed at $80 \mathrm{~m}$ and (b) Virginia offshore wind velocity at $90 \mathrm{~m}$ hub height.

A.32 Virginia wind resource potential: Cumulative rated capacity vs gross capacity factor $(\mathrm{CF})$.

A.34 West Virginia wind resource potential: Cumulative rated capacity vs gross capacity factor $(\mathrm{CF})$ 


\section{LIST OF TABLES}

ES.1 SERC and FRCC 2030 generating capacities under different NEMS runs (GW) ..................xV

ES.2 ERCOT and SPP 2030 generating capacities under different NEMS runs $(\mathrm{GW})$.....................

ES.3 Wind potential for the expanded SE states extracted from the NREL national report (Wind Powering America) ..................................................................................................

ES.4 State-level 2030 renewable generation totals from Markey scenario (TWhr) ........................

2.1 SERC and FRCC 2030 generating capacities under different NEMS runs (GW)...............2-3

2.2 Southeastern renewable generation in 2030 under Markey Bill (TWhr) ............................2-3

2.3 Renewable resources in 2030 from different scenarios and models ..................................2-4

2.4 SERC and FRCC 2030 generation under different NEMS runs (TWhr) ............................2-7

2.52030 nuclear and fossil fuel use and percent change from reference scenario ......................2-8

2.6 ERCOT and SPP 2030 generating capacities under different NEMS runs (GW) ................2-9

2.7 West-south-central states' renewable generation in 2030 under Markey Bill (TWhr) .........2-10

3.1 Wind potential for the expanded southeastern states extracted from the NREL

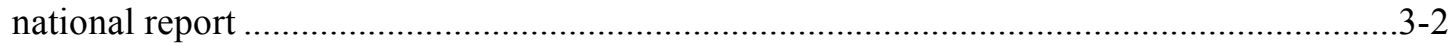

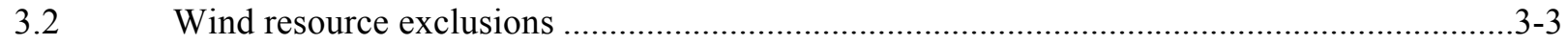

3.3 Wind potential extended southeastern states as fraction of presently installed capacity .........3-4

3.4 Offshore wind resource area by state with potential by wind speed interval to

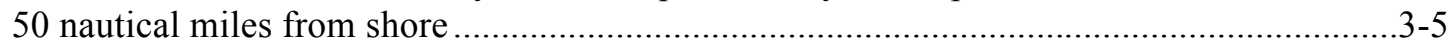

3.5 Southeast offshore wind resource based on distance from shore..........................................

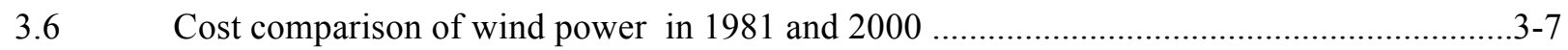

3.7 The economics of a $50 \mathrm{MW}$ wind farm at a wind site with average wind speed of

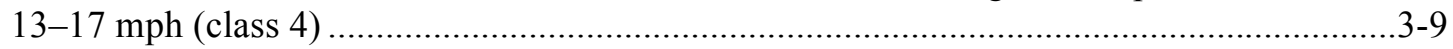

4.1 Annual average solar radiation resource map of southeastern states with different

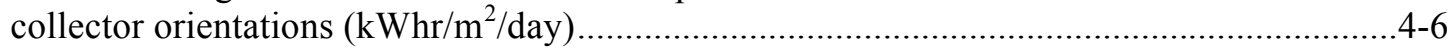

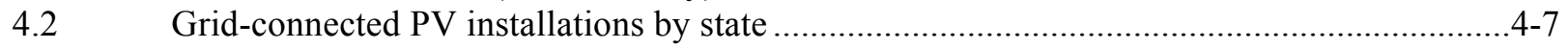

$5.1 \quad$ Extended southern states biofuels resources in 1000 tonnes/year ...................................5-3

5.2 Extended southern states contribution to the national total biofuels resource .......................5-3

5.3 Extended southeastern states biofuels resource in terawatt-hour and gigawatt capacity........5-4

7.1 Projected megawatts-electrical by state and well depth...............................................

7.2 Projected megawatts-electrical by state and well depth......................................................

A.1 Offshore wind resource by state and wind speed internal within $50 \mathrm{~nm}$ of shore ..................3

C.1 Solar manufacturing in Southeast (Ecobusiness Links) .................................................

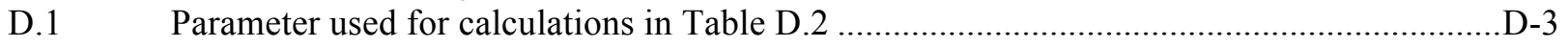

D.2 Solar energy values in different Southeast cities .......................................................... D-3 



\section{ACRONYMS}

\begin{tabular}{|c|c|}
\hline ACESA & American Clean Energy and Security Act \\
\hline AEO & Annual Energy Outlook \\
\hline AEP & American Electric Power \\
\hline ARRA & American Resource and Recovery Act \\
\hline AWEA & American Wind Energy Association \\
\hline BAU & business as usual \\
\hline BLM & Bureau of Land Management \\
\hline BRDI & Biomass Research and Development Initiative \\
\hline CIGS & copper indium gallium selenide \\
\hline CSP & concentrating solar power \\
\hline DOE & Department of Energy \\
\hline DOI & Department of the Interior \\
\hline DWT & distributed wind technology \\
\hline EERE & Office of Energy Efficiency and Renewable Energy \\
\hline EGS & enhanced geothermal systems \\
\hline EIA & Energy Information Administration \\
\hline EPRI & Electric Power Research Institute \\
\hline ERCOT & Electric Reliability Council of Texas \\
\hline FEECA & Florida Energy Efficiency and Conservation Act \\
\hline FPL & Florida Power and Light \\
\hline FRCC & Florida Reliability Coordinating Council \\
\hline GHCP & geothermal hydrocarbon co-production \\
\hline IOU & investor-owned utilities \\
\hline MSW & municipal solid waste \\
\hline MWhr & megawatt-hours \\
\hline NEMS & National Energy Modeling System \\
\hline NERC & North American Electric Reliability Council \\
\hline NESSIE & National Electric System Simulation Integrated Evaluator \\
\hline NREL & National Renewable Energy Laboratory \\
\hline NSRDA & National Solar Radiation Data Base \\
\hline O\&M & operations and maintenance \\
\hline PEIS & Programmatic Environmental Impact Statement \\
\hline PTC & production tax credit \\
\hline PV & photovoltaic \\
\hline RD\&D & research, development, and demonstration \\
\hline ReEDS & Regional Energy Deployment System \\
\hline RES & Renewable Energy Standard \\
\hline RPS & Renewable Portfolio Standard \\
\hline SACE & Southern Alliance for Clean Energy \\
\hline SERC & Southeastern Electric Reliability Council \\
\hline SPP & Southwest Power Pool \\
\hline STC & standard test conditions \\
\hline TACS & thermally activated cooling systems \\
\hline USDA & United States Department of Agriculture \\
\hline \multicolumn{2}{|l|}{ Units } \\
\hline \multicolumn{2}{|c|}{$\begin{array}{l}\text { Units } \\
\text { Bcf = billion cubic feet }\end{array}$} \\
\hline \multicolumn{2}{|c|}{$\mathrm{kWhr}=$ kilowatt-hour } \\
\hline
\end{tabular}





\section{PREFACE}

This summary report is based on a review of existing literature that examines the barriers to and opportunities for integration of renewable energy resources in the southeastern region of the United States. For the purposes of this report, the Southeast initially was defined as the states of Alabama, Arkansas, Florida, Georgia, Kentucky, Louisiana, Mississippi, North Carolina, South Carolina, Tennessee, Virginia, and West Virginia but was expanded to include Maryland, Missouri, Oklahoma, and Texas.

A description of the existing base of renewable electricity installations in the region is provided together with possible limitations and considerations regarding renewable energy resources. Where information is available, the resources are listed in terms of availability, investment and maintenance costs, reliability, installation requirements, policies, and energy market. Not all of the renewable resources have consistent information in these areas. The report assesses possible renewable energy resources in the Southeast and estimates what may be realistically available by the year 2030. In some cases, this time constraint limits a resource that may have larger potential. Examples are offshore wind, tidal, and geothermal energy.

Wind, solar, hydro, biomass, and geothermal resources are discussed in separate sections. General locations are provided for most resources in the form of maps. Each section describes the existing base of the renewable electricity installations present and, where available, the base of the existing manufacturing capacity and supporting industry. Other issues related to renewable energy resources, such as availability, cost, environmental impact, lifetime, reliability, installation requirements, energy market, policy questions, and present technological limits, are also summarized. 



\section{EXECUTIVE SUMMARY}

Several studies have evaluated renewable energy resources in the Southeast. The findings of these studies are briefly discussed in this report, followed by a summary of the present study.

A study by Beck focused on clean energy solutions to improve air and water quality in the Southeast (Beck, 2002. The report references EPA sources that estimate the region produced more $\mathrm{NO}_{x}$ and $\mathrm{SO}_{2}$ pollution in the air per megawatt-hour (MWhr) than the entire United States on an average, while $\mathrm{CO}_{2}$ pollution was less than average. As a solution, the study would press for greater energy efficiency and use of the savings to finance renewable energy generation.

A second study by the Southern Alliance for Clean Energy (SACE) advocates a National Renewable Energy Standard (RES) that would seek to achieve the following goals, which are assumed to apply in their analysis (Wilson, 2009).

- The standard would escalate gradually from today's $4 \%$ generation level to

- a near-term goal of $15 \%$ generation by 2015 ,

- a medium-term goal of $20 \%$ generation by 2020 , and

- a longer-term goal of $25 \%$ generation by 2025 .

- Supplemental federal and state policies will support an RES.

- All utilities will be required to comply.

The SACE noted that the Southeast has been portrayed as a region that will face significant costs and difficulties in meeting a national RES due to limited access to renewable energy resources but believes that this assertion is simply inaccurate. The Southeast has sufficient renewable energy resources to comply with a strong RES. Developing the region's renewable energy potential and meeting a RES will actually benefit the region.

A report entitled Florida Renewable Energy Potential Assessment was prepared by Navigant Consulting for Lawrence Berkeley National Laboratory, the Florida Public Service Commission, and the Florida Governor's Energy Office (Navigant, 2008). The purpose of the study was to examine the technical potential for renewable energy in Florida, through 2020, and to bound potential renewable energy adoption, under various scenarios. Because a statewide Integrated Resource Planning process would need to be undertaken to understand how renewable energy would fit with Florida's current and planned generation assets, current transmission infrastructure and potential future requirements, and Florida's reliability requirements and future energy need, the study does not provide recommendations on Renewable Portfolio Standard (RPS) targets.

Key results of the study are as follows.

- Onshore wind represents a small opportunity (in number of megawatts available) but can be made competitive with financial incentives.

- Confining the definition of eligible resources to those located in the state would drastically reduce the technical potential from offshore wind and ocean-current power.

- Waste heat, re-powering with biomass, co-firing with biomass, anaerobic digester gas facilities (installed in a wastewater treatment plant), and landfill gas are competitive by 2020 in all cases.

- Although it is the one scenario that is unfavorable for renewable energy, ground-mounted photovoltaics (PVs) become competitive at some point during the years of this analysis.

- Because this analysis was completed before a parallel analysis in support of the Florida Energy Efficiency and Conservation Act (FEECA) was available, adoption projections for solar water heating systems of less than $2 \mathrm{MW}$ were not considered. Thus, this analysis does not include the potential energy (in megawatt-hours) available from small solar hot-water systems. 
Primarily based on assumptions regarding the availability of supporting research and technology for the required engineering, the present study was not as optimistic as the above-mentioned studies. For example, because of limited research dollars and less-than-satisfactory results in recent demonstrations, it is highly unlikely that by the year 2030 ocean-based generation using wave or tidal energy will be ready for any significant deployment. On the other hand, conventional hydropower can be expanded significantly with minimal environmental or engineering constraints using presently proven and available technology. Similarly, enhanced geothermal resources in the Southeast are constrained by the fact that very small demonstration projects are just now getting under way nationally. Even in the expanded southeastern region, geothermal energy is not expected to be a viable option until at least 2030. Although this technology has great potential, the engineering needed to deploy and bring the geothermal energy to load centers cannot be rushed to completion.

Modeling future scenarios for a large electric system depends on many often subtle factors, in addition to the scenario assumptions. Capacity expansion and system operation are sensitive to load patterns, existing capacity, and commodity prices for both fuels and emission allowances, which can vary from region to region.

In addition, renewable technologies depend on the extent and quality of wind, solar insolation, moving water suitable for hydropower, and underground thermal conditions. Also, the cost of delivered biomass fuel can vary. Differences in renewable resource availability represent an important factor in understanding the future levelized cost that determines new capacity. Resource quality differences and their availability with respect to time of day (energy output profiles) also help shape the production results for regional systems. The deployment of renewable energy is expected to vary significantly from one region to another, as shown in Fig. ES.1 (Hadley, 2009). Also affecting deployment is regional demand and competing generation options in a region.

Generation by Renewables as Percent of Total Generation, 2020

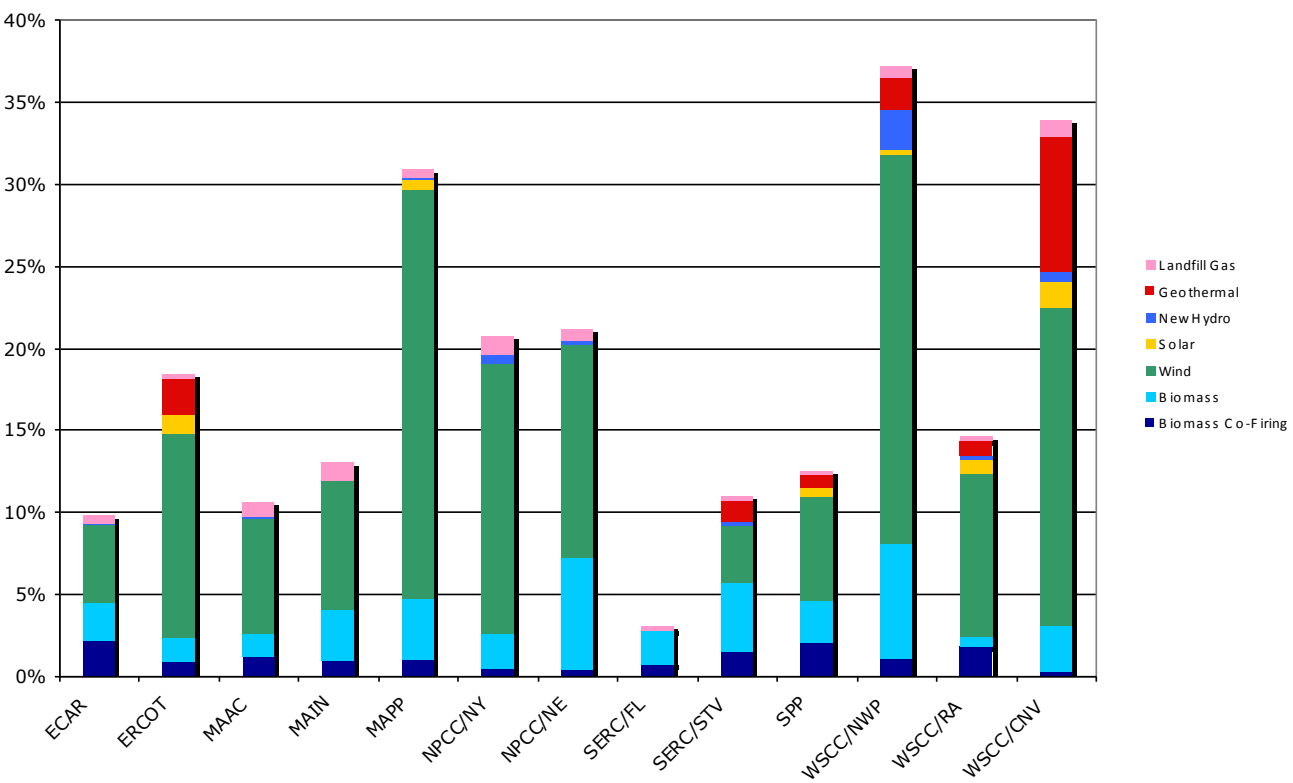

Fig. ES.1. Regional variation in renewable generation, RPS policy case (2020).

A comparison of projected renewable cases for the Southeast with the west-south-central states is provided in Sect. 2. Clearly, the renewable base in the Southeast would benefit from the resources in these states, so this study was expanded to include Missouri, Oklahoma, and Texas, as well as Maryland (Tables ES.1 and ES.2). 
1. Table ES.1. SERC and FRCC 2030 generating capacities under different NEMS runs (GW) ${ }^{a}$

\begin{tabular}{|c|c|c|c|c|c|}
\hline & $\begin{array}{c}\text { AEO } 2009 \\
\text { updated } \\
\text { reference }\end{array}$ & $\begin{array}{c}\text { ACESA RPS } \\
\text { provision } \\
\text { only }\end{array}$ & $\begin{array}{c}\text { ACESA } \\
\text { RPS w/no } \\
\text { eff. credits }\end{array}$ & $\begin{array}{c}\text { ACESA } \\
\text { basic cap } \\
\text { and trade }\end{array}$ & $\begin{array}{c}\text { ACESA no } \\
\text { international/ } \\
\text { limited tech }\end{array}$ \\
\hline Coal & 88 & 85 & 85 & 57 & 45 \\
\hline Oil and gas & 170 & 162 & 161 & 129 & 158 \\
\hline Nuclear & 46 & 45 & 42 & 98 & 46 \\
\hline Pumped storage/other & 8 & 8 & 8 & 8 & 8 \\
\hline Conventional hydropower & 13 & 13 & 13 & 13 & 13 \\
\hline Geothermal & 0 & 0 & 0 & 0 & 0 \\
\hline Biogenic municipal waste & 1 & 1 & 1 & 1 & 2 \\
\hline Wood and other biomass & 7 & 16 & 19 & 10 & 8 \\
\hline Solar thermal & 0 & 0 & 0 & 0 & 0 \\
\hline Solar photovoltaic & 3 & 4 & 4 & 3 & 5 \\
\hline Wind & 4 & 4 & 4 & 4 & 4 \\
\hline Offshore wind & 0 & 0 & 0 & 0 & 4 \\
\hline Total renewable & 27 & 37 & 40 & 30 & 36 \\
\hline Total generating capacity & 339 & 337 & 337 & 322 & 294 \\
\hline
\end{tabular}

${ }^{a}$ SERC $=$ Southeastern Electric Reliability Council, FRCC = Florida Reliability Coordinating Council, AEO = Annual Energy Outlook, ACESA = American Clean Energy and Security Act, RPS = Renewable Portfolio Standard.

Table ES.2. ERCOT and SPP 2030 generating capacities under different NEMS runs (GW)

\begin{tabular}{|c|c|c|c|c|c|}
\hline & $\begin{array}{c}\text { AEO } 2009 \\
\text { updated } \\
\text { reference }\end{array}$ & $\begin{array}{c}\text { ACESA RPS } \\
\text { provision } \\
\text { only }\end{array}$ & $\begin{array}{c}\text { ACESA } \\
\text { RPS w/no } \\
\text { eff. credits }\end{array}$ & $\begin{array}{c}\text { ACESA } \\
\text { basic cap } \\
\text { and trade }\end{array}$ & $\begin{array}{c}\text { ACESA no } \\
\text { international/ } \\
\text { limited tech }\end{array}$ \\
\hline Coal & 45 & 44 & 44 & 50 & 15 \\
\hline Oil and gas & 94 & 93 & 94 & 93 & 93 \\
\hline Nuclear & 7 & 7 & 7 & 19 & 7 \\
\hline Pumped storage/other & 1 & 1 & 1 & 1 & 1 \\
\hline Conventional hydropower & 3 & 3 & 3 & 3 & 3 \\
\hline Geothermal & 0 & 0 & 0 & 0 & 0 \\
\hline Biogenic municipal waste & 0 & 0 & 0 & 0 & 1 \\
\hline Wood and other biomass & 1 & 2 & 5 & 1 & 1 \\
\hline Solar thermal & 0 & 0 & 0 & 0 & 0 \\
\hline Solar photovoltaic & 2 & 2 & 2 & 2 & 3 \\
\hline Wind & 10 & 11 & 18 & 18 & 49 \\
\hline Offshore wind & 0 & 0 & 0 & 0 & 0 \\
\hline Total renewable & 16 & 18 & 28 & 23 & 57 \\
\hline Total generating capacity & 164 & 163 & 174 & 186 & 173 \\
\hline
\end{tabular}

${ }^{a}$ ERCOT $=$ Electric Reliability Council of Texas, SPP $=$ Southwest Power Pool, NEMS = National Energy Modeling System, AEO = Annual Energy Outlook, ACESA = American Clean Energy and Security Act. 
Section 2 also provides a summary of Green Job Opportunities. If renewable power in the Southeast expanded greatly from its current low base, besides the construction and ongoing operation of the generation plants themselves, a manufacturing base to provide the components could also improve job prospects in the region. Two studies from the Renewable Energy Policy Project conclude that more than 32,000 jobs could be developed in the Southeast in support of wind and solar manufacturing (Sterzinger and Svrcek, 2004; Sterzinger and Svrcek, 2005).

Renewable power, being small scale and diverse, often leads to greater ongoing local labor use than large, centralized facilities. A white paper by Nicholas Rigas of Eco Energy LLC and Clemson University states that, based upon the experience of Denmark in developing offshore wind, there could be 17 jobs per megawatt manufactured plus 5 jobs per megawatt installed over the life of a project. These are likely not permanent jobs for each year of the equipment but rather the cumulative jobs over its life. Regardless, there could be a large number of jobs available to the Southeast if renewable resources are expanded in the region.

The wind power resources in the Southeast are mostly in the Appalachian Mountains and offshore. West Virginia, Virginia, Kentucky, Tennessee, and North Carolina have some wind power in the mountains. Virginia, North Carolina, and South Carolina have outstanding wind power resources offshore, and Georgia, Florida, Alabama, Mississippi, and Louisiana have some wind power offshore. The original National Renewable Energy Laboratory (NREL) resource maps for 50 meter heights show very little wind power potential in the Southeast, but the newer 80 meter data are much more favorable. In addition, by expanding the scope of the present study to include Missouri, Oklahoma, Texas, and Maryland, the Southeast's resources increase substantially.

Table ES.3 shows wind potential for the expanded southeastern states, expressed as the windy land area with a gross capacity factor (without losses) $\geq 30 \%$ at a height of $80 \mathrm{~m}$ aboveground and the wind energy potential based on development of the "available" windy land area after exclusions.

Installed capacity column shows the potential megawatts of rated capacity that could be installed on the available windy land area, and annual generation column shows annual wind energy generation in terawatt-hours (TWhr) that could be produced from the installed capacity.

The solar energy resource in the Southeast is shown in Sect. 4 using solar maps that provide monthly average daily total solar resource information on grid cells. The insulation values represent the resource available to a flat plate collector, such as a PV panel, oriented due south at an angle from horizontal to equal to the latitude of the collector location. In the Southeast, most of the states have a solar radiation level of around $5 \mathrm{kWh} / \mathrm{m}^{2} /$ day, except for Tennessee, Kentucky, and West Virginia, which are more at a level of 4 , and a concentrating solar level of around $4 \mathrm{kWh} / \mathrm{m}^{2} /$ day, except for most of West Virginia and part of Kentucky and Tennessee, which are at a level of 3.

Initially included in this assessment of hydropower potential in the Southeast were both the hydrostatic waterpower technologies (conventional hydropower and pumped storage) and the newer hydrokinetic waterpower technologies [in-stream turbines (river, tidal, and constructed waterways) and ocean-wave energy devices]. The water resources considered are all natural or man-made freshwater bodies, estuarine tidal currents, ocean currents (e.g., Gulf Stream), and ocean waves. However, when considering the technological availability of the hydrokinetic resources in the 2020-2030 time frame, it quickly becomes clear that the potential for this resource is very limited. Hence, the energy potential of hydrokinetic and ocean thermal resources are not considered in this review because it is considered to be feasible only for periods well past the 2020 evaluation date for this review.

Essentially all hydro resources in the Southeast are conventional-either run-of-river, consisting of a conventional dam less than 10 feet high with limited storage, or storage type, with a dam greater than 10 feet high and substantial storage capacity.

To go beyond the summary data provided in the INEL potential hydro report and present information about individual water energy resource sites and potential projects would be overly detailed. The data 
Table ES.3. Wind potential for the expanded SE states extracted from the NREL national report ${ }^{a}$ (Wind Powering America)

\begin{tabular}{|c|c|c|c|c|c|c|c|}
\hline \multirow[b]{2}{*}{ State } & \multicolumn{5}{|c|}{ Windy land area $\geq 30 \%$ gross capacity factor at $80 \mathrm{~m}$} & \multicolumn{2}{|c|}{ Wind energy potential } \\
\hline & $\begin{array}{l}\text { Total } \\
\left(\mathbf{k m}^{2}\right)\end{array}$ & $\begin{array}{c}\text { Excluded }^{b} \\
\left(\mathbf{k m}^{2}\right)\end{array}$ & $\begin{array}{c}\text { Available } \\
\left(\mathbf{k m}^{2}\right)\end{array}$ & $\begin{array}{l}\text { Available } \\
\text { percentag } \\
\text { e of state }\end{array}$ & $\begin{array}{c}\text { Percentage } \\
\text { of total } \\
\text { windy land } \\
\text { excluded }\end{array}$ & $\begin{array}{c}\text { Installed } \\
\text { capacity }^{c} \\
\text { (GW) }\end{array}$ & $\begin{array}{c}\text { Annual } \\
\text { generation } \\
\text { (TWhr) }\end{array}$ \\
\hline Alabama & 80.4 & 56.7 & 23.6 & $0.02 \%$ & $70.6 \%$ & 0.1 & 0 \\
\hline Arkansas & $4,663.2$ & $2,823.2$ & $1,840.1$ & $1.34 \%$ & $60.5 \%$ & 9.2 & 32 \\
\hline Florida & 9.6 & 9.5 & 0.1 & $0.00 \%$ & $99.2 \%$ & 0.0 & 0 \\
\hline Georgia & 281.3 & 255.3 & 26.0 & $0.02 \%$ & $90.7 \%$ & 0.1 & 0 \\
\hline Kentucky & 48.7 & 36.6 & 12.1 & $0.01 \%$ & $75.1 \%$ & 0.1 & 0 \\
\hline Louisiana & 125.5 & 43.6 & 82.0 & $0.07 \%$ & $34.7 \%$ & 0.4 & 1 \\
\hline Maryland & 567.7 & 271.1 & 296.6 & $1.18 \%$ & $47.8 \%$ & 1.5 & 5 \\
\hline Mississippi & 0.0 & 0.0 & 0.0 & $0.00 \%$ & N/A & 0.0 & 0 \\
\hline Missouri & $69,676.8$ & $14,805.8$ & $54,871.0$ & $30.39 \%$ & $21.2 \%$ & 274.4 & 961 \\
\hline Oklahoma & $123,243.6$ & $19,879.2$ & $103,364.4$ & $57.10 \%$ & $16.1 \%$ & 516.8 & 1,811 \\
\hline North Carolina & $1,155.6$ & 994.1 & 161.5 & $0.13 \%$ & $86.0 \%$ & 0.8 & 3 \\
\hline South Carolina & 102.8 & 65.8 & 37.0 & $0.05 \%$ & $64.0 \%$ & 0.2 & 1 \\
\hline Tennessee & 359.9 & 298.1 & 61.9 & $0.06 \%$ & $82.8 \%$ & 0.3 & 1 \\
\hline Texas & $435,638.6$ & $55,332.7$ & $380,305.9$ & $55.54 \%$ & $12.7 \%$ & $1,901.5$ & 6,663 \\
\hline Virginia & $1,567.2$ & $1,208.5$ & 358.7 & $0.35 \%$ & $77.1 \%$ & 1.8 & 6 \\
\hline West Virginia & $1,495.2$ & $1,118.6$ & 376.6 & $0.60 \%$ & $74.8 \%$ & 1.9 & 7 \\
\hline Totals & $639,016.3$ & $97,198.8$ & $541,817.5$ & $84.79 \%$ & $15.21 \%$ & $2,709.1$ & $9,492.6$ \\
\hline
\end{tabular}

${ }^{a}$ NREL's wind potential estimates were based on maps produced by AWS Truewind using the MesoMap® system. Table taken from extracted from a NREL national report. For additional information, see Wind Powering America at http://www.windpoweringamerica.gov/.

${ }^{b}$ Excluded lands include protected lands (national parks, wilderness, etc.), incompatible land use (urban, airports, wetland, and water features), and other considerations.

${ }^{c}$ Assumes $5 \mathrm{MW} / \mathrm{km}^{2}$ of installed nameplate capacity.

used and produced in the original INEL study were incorporated into a GIS application and made publicly available on the Internet. This application is called the Virtual Hydro Prospector and is accessible at www.hydropower.inl.gov/prospector/.

An evaluation of the economic parameters used to estimate costs for hydro projects is found in Estimation of Economic Parameters of U.S. Hydropower Resources (July 2003). The parameters are expressed in 2003 dollars, which in most cases were extrapolated from earlier costs. Because hydropower is a well-established technology, the extrapolated values are valid today if escalated to 2010 or later values for future projects. The developed and potential hydro resource expressed in megawatts is shown in Fig. ES.2.

Biomass is already making key energy contributions in the United States and has surpassed hydropower as the largest domestic source of renewable energy. Biomass currently supplies over 3\% of the total U.S. energy consumption-mostly through industrial heat and steam production by the pulp and paper industry and electrical generation with forest industry residues and municipal solid waste (MSW). It is the only current renewable source of liquid transportation fuel, making it an invaluable way to reduce oil imports. Biomass could also provide heat and power to industry and provide feedstocks for a wide range of chemicals and materials or bioproducts. 


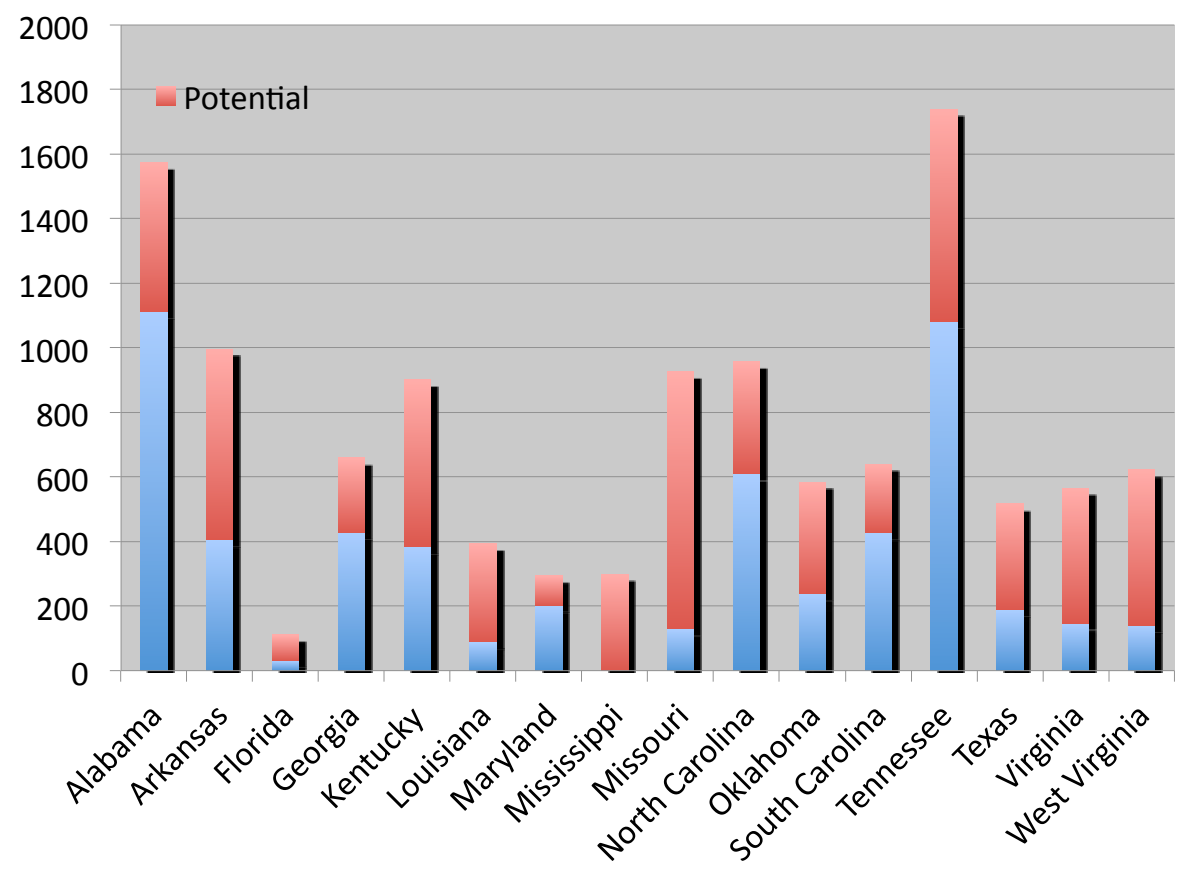

Fig. ES.2. Potential and developed hydro for the expanded Southeast region.

At present about $2.4 \%$ of electric generation is from biomass. While the majority of electric generation is from co-generation facilites, such as paper, furniture, or chemical plants, there are some dedicated steam electric-generation units fueled by biomass. It should be noted that heat rates for these non-combined-cycle plant steam generators are generally higher than those for coal- or natural gas-fired units. However, by co-firing with coal or petroleum coke and using fluidized-bed combustion, some new units have much lower heat rates.

The United States currently leads the world's countries in online geothermal energy capacity and continues to be one of the principal countries to increase its geothermal growth (U.S. Geothermal Power Production and Development Update, April 2010). The United States has a total installed capacity of 3086.6 MW with 4584-7875 MW in development.

Projects under development in the Southeast are located in Louisiana, Mississippi, and Texas. Louisiana currently hosts two known developing geothermal projects. One, a $0.05 \mathrm{MW}$ project, is a planned geothermal hydrocarbon co-production (GHCP) unit at a producing gas field. Another 5.25 MW project, which has been awarded \$5million in American Resource and Recovery Act (ARRA) funding from the DOE Geothermal Technologies Program, will develop geopressured resources at an oil and gas field and is in the advanced stage of development. Mississippi's first developing geothermal project is rated at $0.05 \mathrm{MW}$ and is a planned GHCP unit at a producing oil field. The first developing geothermal project in Texas is a $0.4 \mathrm{MW}$ planned GHCP unit.

It is quite clear that no natural geothermal resources exist in the expanded southeastern states and that work on geopressured installations is just beginning. However, the potential for development of more advanced enhanced geothermal systems (EGS) projects that could provide a substantial amount of future energy resources requires further discussion. Given the present status of the geothermal demonstration projects in the Southeast, it is very unlikely that significant energy will be extracted from EGS sources prior to 2030.

If renewable resources in the expanded southeastern region are to be used in the original southeastern states, a substantial expansion of the power grid must be undertaken. A paper by American Electric Power (AEP) provides a vision of a $765 \mathrm{kV}$ grid expansion. According to the paper, 
the nation's bulk transmission system is currently inadequate to deliver energy from remote wind resource areas to electrical load centers; located mainly on the East and West coasts. AEP believes that this barrier can be overcome by building transmission infrastructure that will enable wind power to become a larger part of the nation's power generation resource mix. This transmission system expansion will bring many additional societal benefits, including increased reliability and greater access to lower cost and environmentally friendly resources.

Another study, funded by ORNL and EPRI (Hadley, 2009), provides support to this conclusion.

When considering how much wind from other regions will be needed to meet the renewable portfolio standard in the southeast, it becomes clear that without massive investment in biomass and solar technologies, imported wind is the best choice. To bring in this wind large amounts of transmission will be needed. It then becomes a question of how much the solar and biomass can realistically be deployed in the next 11 years. While biomass generation has an established base in the region, a scale-up from the current projection of $12 \mathrm{TWhr}$ will require the construction of new plants, conversion of existing fossil plants, and an established biomass fuel production infrastructure. Solar production has not been developed in the southeast yet. An expansion to cover $\sim 1 \%$ of the land area of the southeast would be required but is not likely in the near term.

A study by NREL on RPS proposals (Sullivan, 2009) includes state-by-state generation by different renewable technologies (Table ES.4). The analysis was done using the Regional Energy Deployment System (ReEDS) model, and the data shown in the table is the sum for the 11 states in the Southeast, as opposed to the Southeastern Electric Reliability Council (SERC) and Florida Reliability Coordinating Council (FRCC) regions. The data represents their modeling of the Markey's bill H.R. 890, the American Renewable Energy Act for the year 2030. Even though this bill required the most renewable generation of the three studied, $25 \%$ by 2025 , the southeastern states did not generate the required amounts. Instead, they were expected to import renewable power and/or purchase renewable energy credits from states with surpluses.

The amounts above represent only the electricity generated by the electricity sector and do not include industrial or other sectors' generation for their own end use. Particularly in the Southeast, generation from biomass through cogeneration at paper mills provides significant quantities of electricity. This electricity is not greatly affected by changes in plans and does not qualify for tradable renewable energy credits in some of the bills under discussion.

This table also shows that different models and associated assumptions can result in significant differences in the amount and type of generation developed. The ReEDS model analysis of the Markey RPS develops a large amount of solar and wind resources, while the NEMS analysis supplies most renewable generation in the Southeast from biomass.

Interstate transmission of renewable energy may not be the answer. Recent observations by Opalka (2010) on the RenewablesBiz website suggest that the issue may be quite unclear and must await a more detailed analysis. The entire issue results from a simple phrase added to the Senate energy bill last year, the Corker amendment, that transmission cost allocation should be limited to those who enjoy a direct benefit. 
Table ES.4. State-level 2030 renewable generation totals from Markey scenario (TWhr) ${ }^{a}$

\begin{tabular}{lrrrc}
\hline \multicolumn{1}{c}{ State/resource } & Wind & Solar & Bio & Geo \\
\hline Alabama & 0.0 & 0.0 & 1.4 & 0.0 \\
Arkansas & 0.4 & 0.0 & 0.7 & 0.0 \\
Florida & 2.9 & 3.2 & 11.0 & 0.0 \\
Georgia & 2.1 & 0.0 & 1.6 & 0.0 \\
Kentucky & 1.7 & 0.9 & 0.8 & 0.0 \\
Louisiana & 3.9 & 2.8 & 0.7 & 0.0 \\
Mississippi & 0.0 & 0.0 & 1.2 & 0.0 \\
North Carolina & 10.8 & 7.0 & 7.0 & 0.0 \\
South Carolina & 0.4 & 1.5 & 2.2 & 0.0 \\
Tennessee & 1.0 & 0.0 & 1.5 & 0.0 \\
Virginia & 2.5 & 1.7 & 1.4 & 0.0 \\
West Virginia & 1.6 & 0.0 & 0.4 & 0.0 \\
$\quad$ Subtotal nominal & & & & \\
$\quad$ Southeast & 27.3 & 17.1 & 29.9 & 0.0 \\
Maryland & 9.0 & 0.0 & 0.3 & 0.0 \\
Missouri & 13.4 & 0.0 & 0.8 & 0.0 \\
Oklahoma & 20.5 & 0.0 & 1.5 & 0.0 \\
Texas & 56.6 & 13.9 & 4.6 & 0.0 \\
Subtotal (MMOT) & 99.5 & 13.9 & 7.2 & 0.0 \\
$\quad$ Total expanded & & & & \\
$\quad$ Southeast & 126.8 & 31.0 & 37.1 & 0.0 \\
\hline “
\end{tabular}

${ }^{a}$ Table taken from Sullivan (2009).

\section{REFERENCES}

Beck, Fredric, et al. January 2002. Powering the South: A Clean Affordable Energy Plan for the Southern United States, Renewable Energy Policy Project, Washington, D.C.

Hadley, Stanton W., Key, Thomas, and Deb, Rajat. November 2009. Power Transfer Potential to the Southeast in Response to a Renewable Portfolio Standard: Final Report, ORNL/TM-2009/239.

Idaho National Laboratory, Estimation of Economic Parameters of U.S. Hydropower Resources,

INEEL/EXT-03-00662, July 2003.

Jennejohn, D. April 2010. US Geothermal Power Production and Development Update, Geothermal Energy Association, Washington, D.C., www.geo-energy.org

Navigant Consulting. December 2008. Florida Renewable Energy Potential Assessment.

Opalka, Bill. May 11, 2010. Is Interstate Transmission Really the Answer?

http://www.renewablesbiz.com/.

Sterzinger, G., Svrcek, M. September 2004. Wind turbine development: Location of manufacturing activity. Renewable Energy Policy Project (REPP), Washington, DC.

Sterzinger, G., Svrcek, M. January 2005. Solar PV development: Location of economic activity. Renewable Energy Policy Project (REPP).

Sullivan, Patrick, et al. May 2009. Comparative Analysis of Three Proposed Federal Renewable Electricity Standards, NREL/TP-6A2-45877, National Renewable Energy Laboratory.

Wilson, John, et al. February 2009. Yes We Can: Southern Solutions for a National Renewable Energy Standard, Southern Alliance for Clean Energy. 


\section{INTRODUCTION}

The objectives of this study were to prepare a summary report that examines the opportunities for and obstacles to the integration of renewable energy resources in the Southeast between now and the year 2030. The report, which is based on a review of existing literature regarding renewable resources in the Southeast, includes the following renewable energy resources: wind, solar, hydro, geothermal, biomass, and tidal. The evaluation was conducted by the Oak Ridge National Laboratory for the Energy Foundation and is a subjective review with limited detailed analysis. However, the report offers a best estimate of the magnitude, time frame, and cost of deployment of renewable resources in the Southeast based upon the literature reviewed and reasonable engineering and economic estimates. For the purposes of this report, the Southeast is defined as the states of Alabama, Arkansas, Florida, Georgia, Kentucky, Louisiana, Mississippi, North Carolina, South Carolina, Tennessee, Virginia, and West Virginia. In addition, some aspects of the report (wind and geothermal) also consider the extended Southeast, which includes Maryland, Missouri, Oklahoma, and Texas. A description of the existing base of renewable electricity installations in the region is given for each technology considered. Where available, the possible barriers and other considerations regarding renewable energy resources are listed in terms of availability, investment and maintenance costs, reliability, installation requirements, policies, and energy market.

As stated above, the report is a comprehensive review of renewable energy resources in the southeastern region of United States based on a literature study that included information obtained from the Southern Bio-Power wiki, sources from the Energy Foundation, sources available to ORNL, and sources found during the review. The report consists of an executive summary, this introductory chapter describing report objectives, a chapter on analysis methods and the status of renewable resources, chapters devoted to each identified renewable resource, and a brief summary chapter.

Chapter 2 on analysis methods and status summarizes the benefits of integrating renewable energy resources in the Southeast. The utilization of the existing fuels, both the fossil fuels and the renewable energy resources, is evaluated. The financial rewards of renewable resources are listed, which includes the amount of fuel imported from outside the Southeast to find the net benefit of local renewable generation, and both the typical and new green job opportunities that arise from renewable generation in the Southeast.

With the load growth in the Southeast, the growth of transmission and fossil fuel generation may not meet the growing demands for energy. The load growth is estimated, and the benefits of renewable resources for solving local growing energy demands are evaluated.

Chapters 3-7 discuss the key renewable energy resources in the Southeast. Six resources available in this region that are discussed are (1) wind, including both onshore and offshore; (2) solar, including passive, photovoltaic, and concentrating; (3) biomass energy, including switchgrass, biomass co-firing, wood, woody biomass, wood industry by-products (harvesting residues, mill waste, etc.), agricultural byproducts, landfill gas to energy and anaerobic digester gas; (4) hydro; and (5) geothermal. Because of limited development, ocean wave and tidal were not considered to be available in significant quantity before 2030 and are not presented in the final analysis. Estimates on the location of potential megawatt generation from these renewable resources in the Southeast are made.

Each chapter will describe the existing base of the renewable electricity installations in the region now and, when available, the base of the existing manufacturing capacity in the region for renewable energy resources hardware and software. The possible barriers and considerations for renewable energy resources are presented.

When relevant information is found, issues such as availability, cost, environmental impacts, reliability and lifetime, installation, site requirements, policy issues, etc., will be summarized.

These issues are defined as follows:

1. Availability: Which renewable energy technologies are available for installation now and which will be available in the longer term? For example, those currently available in the market are land-based 
wind, bio-power, hydroelectric, and photovoltaic, while off-shore wind, enhanced geothermal, and ocean are available but have not matured in the market.

2. Costs: What base capital costs (initial construction) can be anticipated with renewable energy resources? How do these costs compare to fossil and nuclear alternatives? Are additional components necessary that add costs to the overall capital, such as power electronics and energy storage? What are the operating and maintenance costs and fuel costs? What is the annual cost amortized over 20 years? What is the lead time compared to fossil and nuclear alternatives? For example, high demand of a particular energy type can lead to delayed delivery, and construction of mass-scale energy products can take years.

3. Environment impacts: What are the effects of a move to renewable energy resources on the environment?

4. Reliability/lifetime: Reliability considerations include the effects of weather and the environment on generation, energy storage requirements, grid integration, the mix of multiple sources of renewables, and the relationship between the aggregation of sources and reliability. Where information is available, the report examines the lifetime of the components, the cost of component replacement, and the maintenance requirements.

5. Installation and site requirements: What is the correct location for placement of energy sources? Each design is currently unique, and proper guidelines must be followed for power system installation. Trained installers will be needed.

6. Policies: Both the government and the utilities have policies or interconnection guidelines that need to be followed. Policies and guidelines related to the installation of renewable energy resources are discussed.

7. Energy market: The adequacy of existing generation prediction models for renewable energy resources in the current energy market is estimated. Renewable energy resources can provide ancillary services such as spinning reserve and reactive power generation and have value in addition to providing energy. 


\section{ANALYSIS METHODS AND STATUS}

\section{$2.1 \quad$ INTRODUCTION}

Renewable energy has been used in the Southeast for millennia, by Native Americans and more recently by settlers. The most well-known use has been the development of the Tennessee Valley Authority in the 1930s, but electricity generation from hydro and other resources has been used by a wide variety of utilities and end users over the years. The question that arises now is whether the main resources been tapped already or if there are new sources available for further growth. What types of renewables that are available? How much capacity is available and at what cost? The purpose of this report is to conduct a review of existing research to bring together estimates of renewable resources available in the Southeast.

There are multiple benefits to the integration of renewable energy into the energy mix of the Southeast. Among others, it provides a more diverse resource base to meet electricity demand, reduces the amount of imported fuels into the region, and provides jobs within the local economies.

\subsection{MEETING LOAD GROWTH WITH DIVERSE RESOURCES}

Renewable energy expansion adds to the mix of energy sources used to provide electricity with fuels that are clean and sustainable. The current mix of fuels is dominated by coal, providing roughly $50 \%$ of all generation. Natural gas and nuclear power also provide significant fractions. Currently hydropower is the major source of renewable energy in the South. There are several others that have potential for expansion, as related in the following sections.

A number of studies that have forecast the potential contribution from various renewable energy sources. The models all show different mixes, based on a combination of the input assumptions and the algorithms used in the models. Some only considered renewable portfolio standards (RPSs), while others included carbon cap and trade. Within these studies, the portfolio standard may have been defined differently, such as what technologies are included or whether energy efficiency qualifies as a resource. Similarly, cap and trade parameters that could be vary between studies.

\subsubsection{EIA Analyses}

The Energy Information Administration (EIA) uses an energy-economic model for analyzing key policy questions, the National Energy Modeling System (NEMS). The EIA developed this model to forecast national and regional energy supply and demand through 2035. Detailed information on the model can be found in the National Energy Modeling System: An Overview 2009 (EIA, 2009a). NEMS models the major end-use sectors of the economy: residential, commercial, industrial, and transportation. Within the energy sector, it models electricity, oil, gas, coal, and renewable energy production. It separates the nation into 13 geographical regions for analysis, providing regional information on energy and economic results.

Recent NEMS runs offer a variety of estimates of renewable energy growth patterns, depending on the market conditions. The EIA has run a number of recent scenarios built on a basic scenario that includes the January 2009 stimulus bill and the effects of the recent recession (EIA, 2009b). Other cases analyzed variations on the cap and trade bill HR 2454, also known as the American Clean Energy and Security Act of 2009, or ACESA (EIA 2009c; EIA2009d). There are several provisions in the bill, including a renewable portfolio standard, credits for energy efficiency, carbon cap\& trade, different amounts of banking of credits allowed, and varying levels of international offsets to emissions. Various scenarios run by EIA include some of these different parameters, along with different assumptions regarding the development of nonrenewable technologies. For this report, we will examine a subset of the scenarios that have a broad impact on the nation's renewable development. 
- Annual Energy Outlook 2009 Updated Reference Scenario

- ACESA Renewable Portfolio Standard

- RPS, assuming no energy efficiency credits

- ACESA Basic Case

- ACESA with no international offsets and limited technology development

For this report, we extracted the results for the Florida Reliability Coordinating Council (FRCC) and Southeastern Electric Reliability Council (SERC) regions (regions 8 and 9 in Fig. 2.1). These regions are based on historical North American Electric Reliability Council (NERC) regions. Although in recent years the NERC regions have changed, the EIA (and other modelers) continue to use the historical regions for continuity.

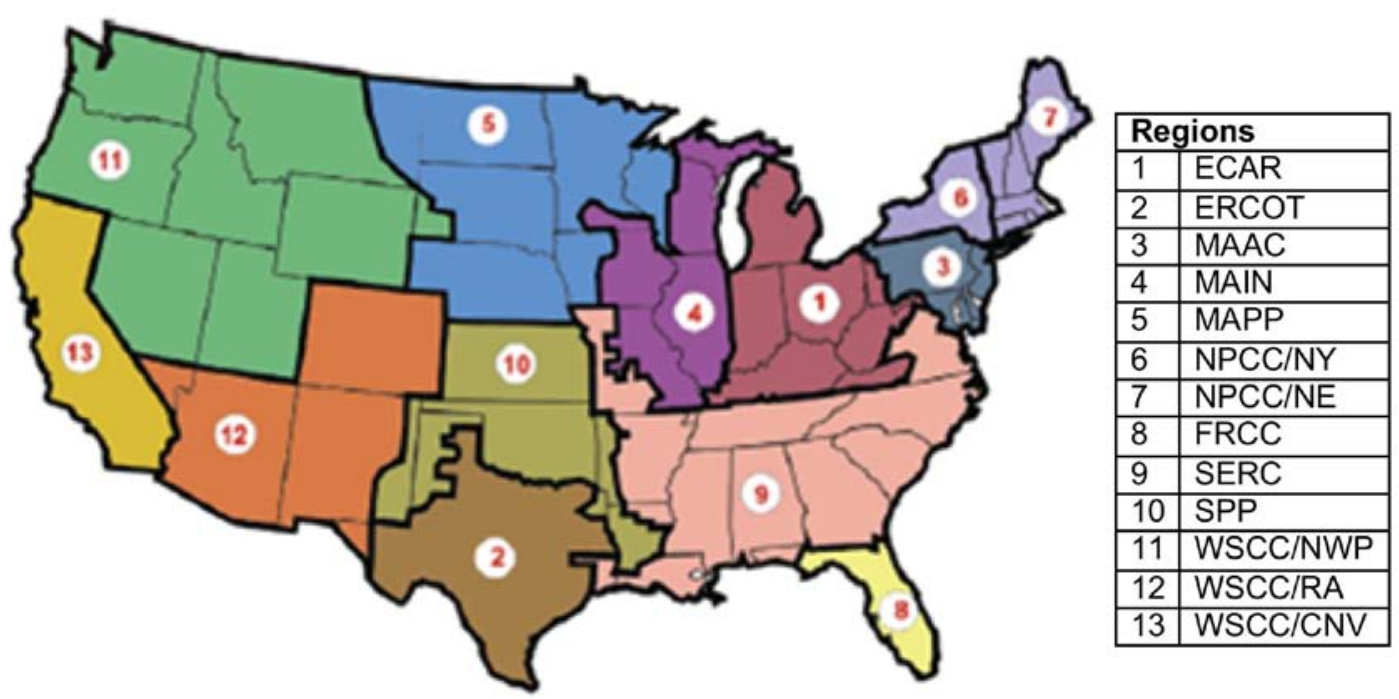

Fig. 2.1. Thirteen NERC regions used in NEMS and other models.

Under the Annual Energy Outlook (AEO) 2009 reference scenario, electricity demand in the regions increases from $1120 \mathrm{TWhr}$ in 2010 to $1380 \mathrm{TWhr}$ in 2030. This translates into a 1.1\% annual growth rate. While SERC is almost $80 \%$ of the combined regions, it is growing at a smaller rate $(1.0 \%)$ than FRCC $(1.4 \%)$.

With energy efficiency, growth can be reduced significantly. A companion study is analyzing the impact of various energy efficiency programs and policies in reducing demand. Initial estimates show demand reductions of roughly $20 \%$ by 2030 , keeping demand relatively flat.

Renewable Portfolio Standards and carbon cap and trade policies have a significant impact on load growth and the types of technology used to supply that load. Table 2.1 lists the amount of capacity by fuel type in SERC and FRCC in 2030. The RPS scenarios advance renewables in the Southeast the most, with as much as $40 \mathrm{GW}$ of renewable power owned by either electric utilities or end users. The cap and trade scenarios have somewhat less development, though more than in the reference scenario. Full analyses of these scenarios and others are provided on the EIA website, although only at a national level.

\subsubsection{NREL ReEDS Model}

The National Renewable Energy Laboratory (NREL) developed the Regional Energy Deployment System (ReEDS) model to analyze energy and climate policy options in the U.S. electricity sector. ReEDS is a linear programming model that simulates the least-cost expansion of electricity generation 
Table 2.1. SERC and FRCC 2030 generating capacities under different NEMS runs (GW)

\begin{tabular}{|c|c|c|c|c|c|}
\hline & $\begin{array}{c}\text { AEO } 2009 \\
\text { updated } \\
\text { reference }\end{array}$ & $\begin{array}{c}\text { ACESA RPS } \\
\text { provision } \\
\text { only }\end{array}$ & $\begin{array}{c}\text { ACESA RPS } \\
\text { w/no eff. } \\
\text { credits } \\
\end{array}$ & $\begin{array}{c}\text { ACESA } \\
\text { basic cap } \\
\text { and trade }\end{array}$ & $\begin{array}{c}\text { ACESA No } \\
\text { international/ } \\
\text { limited tech }\end{array}$ \\
\hline Coal & 88 & 85 & 85 & 57 & 45 \\
\hline Oil and gas & 170 & 162 & 161 & 129 & 158 \\
\hline Nuclear & 46 & 45 & 42 & 98 & 46 \\
\hline Pumped storage/other & 8 & 8 & 8 & 8 & 8 \\
\hline Conventional hydropower & 13 & 13 & 13 & 13 & 13 \\
\hline Geothermal & 0 & 0 & 0 & 0 & 0 \\
\hline Biogenic municipal waste & 1 & 1 & 1 & 1 & 2 \\
\hline Wood and other biomass & 7 & 16 & 19 & 10 & 8 \\
\hline Solar thermal & 0 & 0 & 0 & 0 & 0 \\
\hline Solar photovoltaic & 3 & 4 & 4 & 3 & 5 \\
\hline Wind & 4 & 4 & 4 & 4 & 4 \\
\hline Offshore wind & 0 & 0 & 0 & 0 & 4 \\
\hline Total renewable & 27 & 37 & 40 & 30 & 36 \\
\hline Total generating capacity & 339 & 337 & 337 & 322 & 294 \\
\hline
\end{tabular}

capacity and transmission, with detailed treatment of renewable electric options. ReEDS minimizes the system-wide cost of meeting forecasted electric loads, reserve requirements, and emission constraints by building and operating new generators and transmission in 22 two-year increments from 2006 to 2050.

A recently released study by NREL on RPS proposals (Sullivan, 2009) includes a table that shows the state-by-state generation by different renewable technologies (Table 2.2). The analysis was done using their ReEDS model, and the data shown in the table is the sum for the 11 states in the Southeast (as opposed to the SERC and FRCC regions). The data represents their modeling of the Markey's bill H.R. 890, the American Renewable Energy Act for the year 2030. Even though this bill required the most renewable generation of the three studied, $25 \%$ by 2025 , the southeastern states did not generate the required amounts. Instead, they were expected to import renewable power and/or purchase renewable energy credits from states with surpluses.

Table 2.2. Southeastern renewable generation in 2030 under Markey Bill (TWhr) ${ }^{a}$

\begin{tabular}{lllll}
\hline & Wind & Solar & Bio & Total \\
\hline Alabama & 0 & 0 & 1.4 & 1.4 \\
Arkansas & 0.4 & 0 & 0.7 & 1.1 \\
Florida & 2.9 & 3.2 & 11 & 17.1 \\
Georgia & 2.1 & 0 & 1.6 & 3.7 \\
Louisiana & 3.9 & 2.8 & 0.7 & 7.4 \\
Mississippi & 0 & 0 & 1.2 & 1.2 \\
Missouri & 13.4 & 0 & 0.8 & 14.2 \\
North Carolina & 10.8 & 7.0 & 7.0 & 24.8 \\
South Carolina & 0.4 & 1.5 & 2.2 & 4.1 \\
Tennessee & 1.0 & 0 & 1.5 & 2.5 \\
Virginia & 2.5 & 1.7 & 1.4 & 5.6 \\
$\quad$ Total & 37.4 & 16.2 & 29.5 & 83.1 \\
\hline
\end{tabular}

${ }^{a}$ Source: Sullivan (2009) 
The amounts above represent only the electricity generated by the electricity sector and do not include industrial or other sectors' generation for their own end use. Particularly in the Southeast, generation from biomass through cogeneration at paper mills provides significant quantities of electricity. These amounts are not greatly affected by changes in plans and do not qualify for tradable renewable energy credits in some of the bills under discussion. Under the AEO 2009 with stimulus package scenario by 2030 there is $37 \mathrm{TWhr}$ of qualified renewable resources from end users, while in the Waxman RPS the total is only 36 TWhr (Table 2.3).

Table 2.3. Renewable resources in $\mathbf{2 0 3 0}$ from different scenarios and models

\begin{tabular}{lccccccccc}
\hline & $\begin{array}{c}\text { Markey RPS } \\
\text { (ReEDS) }\end{array}$ & \multicolumn{2}{c}{ AEO 2009 with stimulus (NEMS) } & & \multicolumn{3}{c}{ Waxman RPS (NEMS) } \\
\cline { 3 - 4 } \cline { 7 - 9 } & & Elec sector & End Use & Total & & Elec sector & End Use & Total \\
\hline Wind & 37 & 11 & 0 & 11 & & 11 & 0 & 11 \\
Solar & 16 & 0 & 5 & 5 & & 0 & 7 & 7 \\
Biomass & 30 & 18 & 32 & 50 & & 129 & 28 & 157 \\
$\quad$ Total & 83 & 29 & 37 & 66 & & 139 & 36 & 175 \\
\hline
\end{tabular}

Another point to be made from this table is that different models and associated assumptions can give large differences in the amount and type of generation developed. The ReEDS model analysis of the Markey RPS develops a large amount of solar and wind resources, while the NEMS analysis supplies most renewable generation in the Southeast from biomass.

It is an important point that NEMS is a general equilibrium model where supply and demand are specified as functions. Thus, both supply and demand change as the model solves for equilibrium. The equilibrium is reached by finding the demand that is consistent with the prices generated by the supply function. If a scenario leads to higher costs for electricity, then the demand for electricity will drop. The next model discussed, the National Electric System Simulation Integrated Evaluator (NESSIE), follows the same equilibrium approach for the electric sector, starting with results from NEMS as an input.

\subsubsection{EPRI NESSIE Model}

Modeling future scenarios for a large electric system depends on many, often subtle, factors in addition to the scenario assumptions. Capacity expansion and system operation are sensitive to load patterns, existing capacity, and commodity prices for both fuels and emission allowances. These factors vary from region to region. The Electric Power Research Institute (EPRI) computer model NESSIE (National Electric System Simulation Integrated Evaluator) models the country's electric system using results from NEMS but extends them to 2050 while allowing further modeling of capacity expansion and power production.

In addition, renewable technologies depend on the extent and quality of wind, solar insolation, moving water suitable for hydro, and underground thermal. Also, the cost of delivered biomass fuel can vary. Differences in renewable resource availability represent an important factor in understanding the future levelized cost that determines new capacity additions. In addition, the resource quality differences and the availability with respect to time of day (energy output profiles) help shape the production results for the regional systems. The deployment of renewable energy is expected to vary significantly from one region to another, as shown in Fig. 2.2 (Hadley et al., 2009a). Also affecting the deployment is regional demand and competing generation options in a region.

Figure 2.3 shows the potential renewable resources projected for the different SERC regions of the Southeast. (Entergy, Southern, TVA, and VACAR are the four subregions within the SERC region used by NEMS and NESSIE.) This data is from a follow-on analysis to the results shown in Fig. 2.2 that evaluates the demands and supplies in the four subregions of SERC plus FRCC (Hadley et al., 2009b). 


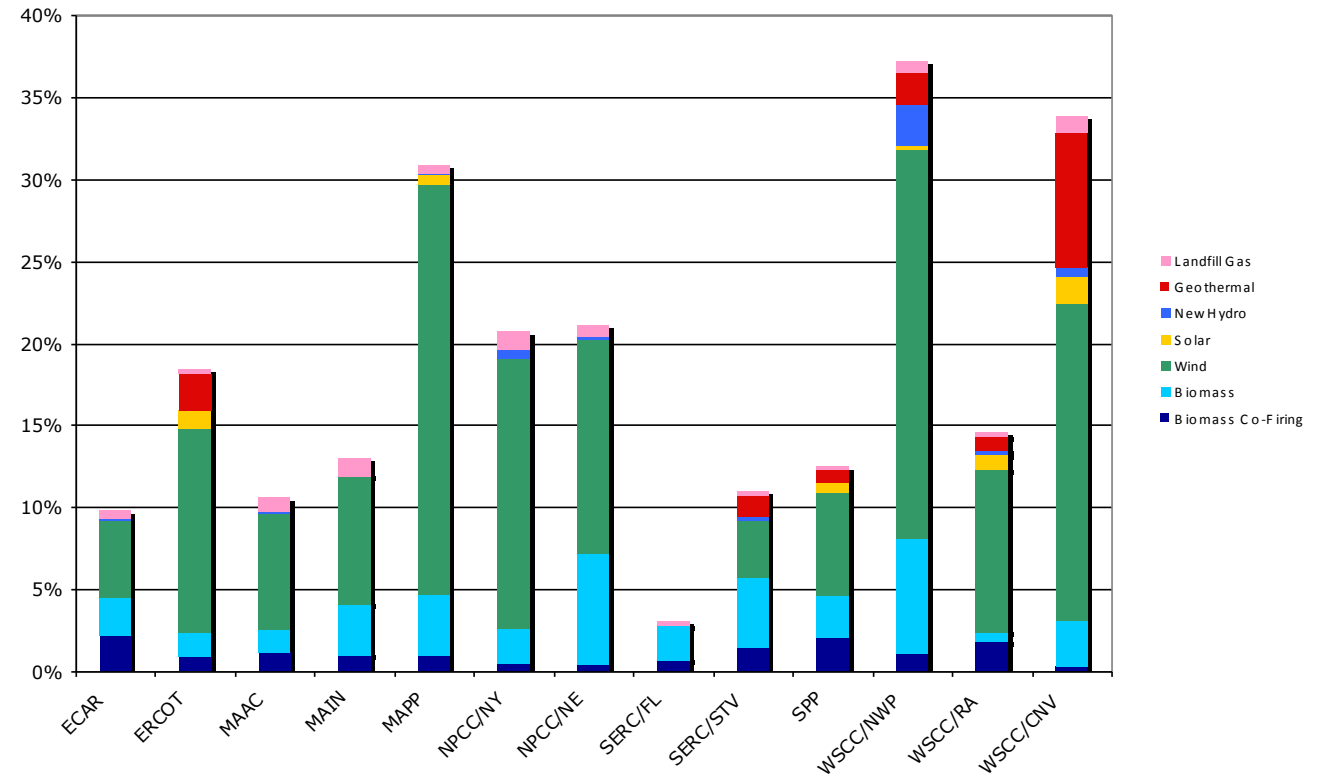

Fig. 2.2. Regional variation in renewable generation, RPS policy case (2020). Source: Hadley et al. (2009a).

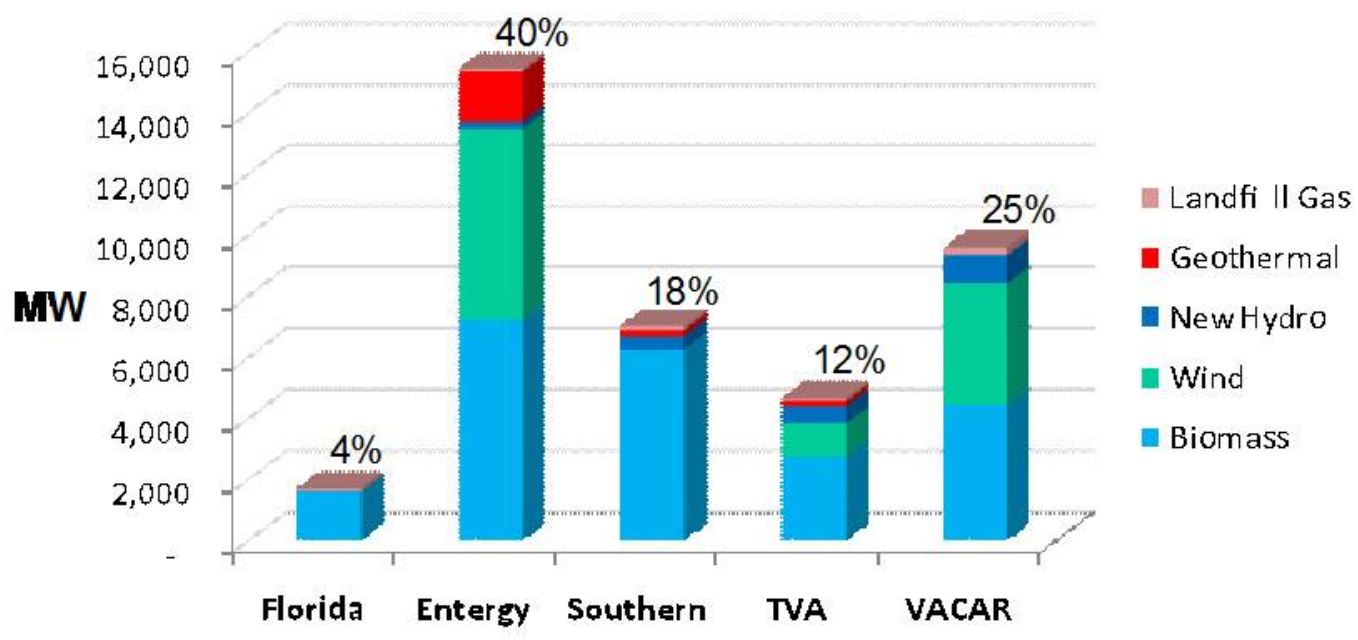

Fig. 2.3. NESSIE distribution of selected resources in the Southeast. (Solar PV resource is unlimited but constrained by economics.) Source: Hadley et al. (2009b).

EPRI has also conducted an analysis of the impact of RPS and cap and trade scenarios on generation across the United States. Figure 2.4 shows the changes in generation in SERC under a business-as-usual (BAU) scenario, RPS scenario, and carbon cap-and-trade $\left(\mathrm{CO}_{2}\right)$ scenario. As mentioned above, these analyses were done using specific values for RPS and cap-and-trade policies; variations will give somewhat different answers. Note that NESSIE projects some penetration of geothermal power in the Southeast. As with NEMS, the majority of growth in renewable power comes from biomass (Hadley and Key, 2009). 


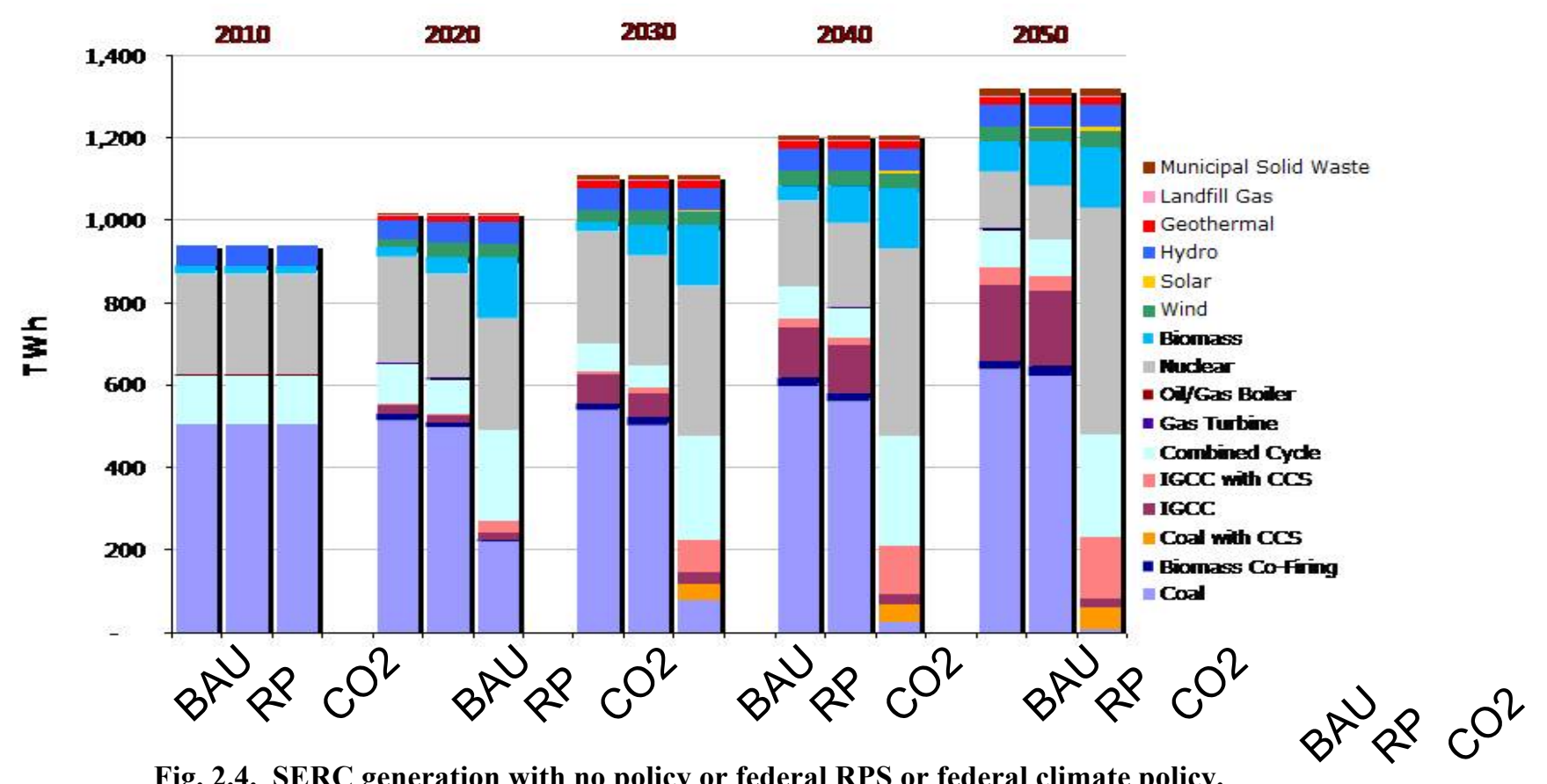

\subsubsection{LCG Consulting UPLAN Model}

LCG Consulting's Network Power Model (UPLAN) is an integrated electricity generation and transmission model developed to simulate both the behavior of market participants and the physical features of the electricity system. It projects detailed physical and financial operations of electricity markets conditions ranging from traditional regulation to today's post-restructuring competitive market structures. The model provides the consistent, structured framework, as well as the detailed quantitative inputs and results, required to evaluate the full implications of different fundamental drivers and market participant decisions.

LCG has developed a DC model for the Eastern Interconnection. Each control area is represented and connected by inter-ties that represent the transmission system and carry electricity between the control areas. The model includes all the generators and hourly loads of all the control areas in the regions mentioned. The Eastern Interconnect Model simulates the flows from and to neighboring areas and provides imports/exports and comparative price performance of a zone.

LCG contributed to the analysis of the potential transfer of power from the Midwest to the Southeast to meet any RPS requirements (Hadley et al., 2009a). The analysis considered the expected generation and transmission in 2020. Figure 2.5 shows the mix of generation. At $9 \mathrm{GW}$, they expect a larger amount of wind than NESSIE or NEMS but a much lower biomass amount, 1.6 GW.

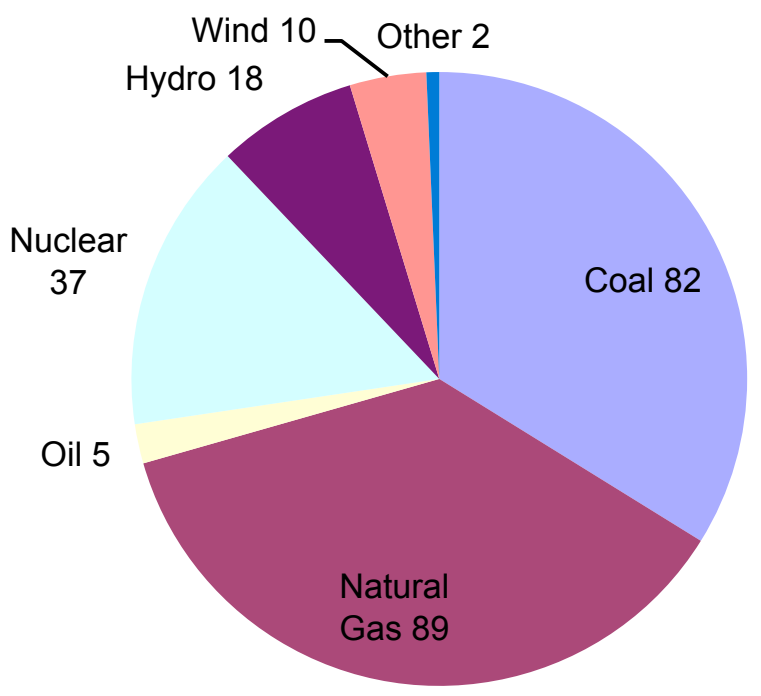

Fig. 2.5. UPLAN estimate of 2020 capacities in $\operatorname{SERC}($ GW). 


\subsection{NUCLEAR AND FOSSIL FUEL SUBSTITUTION}

An increase in locally produced renewable energy can lower the amount of fossil fuel or uranium that would otherwise be needed to meet demand. A significant fraction of electricity in the South is provided by coal. While some of that coal is mined within the South, such as eastern Kentucky or West Virginia, much of it is imported from the western coal regions because of their lower sulfur content and relative cost.

Natural gas is also a major contributor to electric power generation. The gas used in the South is largely produced from local sources such as the Gulf Coast. However, use of the fuel precludes it from being exported to other regions, bringing in outside revenues to assist the local economy.

Renewable power development could displace existing natural gas, coal, or nuclear generation, depending on the relative costs, generation profile, and load growth for the region. Renewable power generated during off-peak periods of low demand are most likely to displace coal production, since coal power has the lowest cost and the marginal production during low power times. During periods of higher demand, natural gas is the marginal producer, so renewable generation during that time would displace natural gas production. Nuclear power is even more of a base load generator than coal and is unlikely to see reductions in dispatch due to renewables.

Renewable power development will supplant development of any of these generation technologies. The largest impact will be on coal capacity, though mainly due to the underlying policies that create incentives for renewables also create disincentives for coal capacity. Climate change policies such as $\mathrm{CO}_{2}$ cap and trade or carbon taxes will impact coal production the most because of its high carbon content. Even the uncertainty of future restrictions serves to reduce the likelihood of new coal plants being built. Nuclear power has its own set of uncertainties but does not produce $\mathrm{CO}_{2}$. Several of the RPS proposals absolve new nuclear in the calculation of the percentage required from renewable power. Natural gas capacity may be pared back because of renewable capacity growth or may expand to provide the swing capacity needed in the face of renewable's variable generation characteristics. Low-cost capacity that can rapidly change production levels will be needed to counteract the vagaries of production tied to sun or wind.

Using the same set of NEMS scenarios as in Table 2.1, the generation, in terawatt-hours, from each technology is shown in Table 2.4 and Fig. 2.6. Under the RPS scenarios, the biomass generation increases

Table 2.4. SERC and FRCC 2030 generation under different NEMS runs (TWhr)

\begin{tabular}{lccccc}
\hline & $\begin{array}{c}\text { AEO 2009 } \\
\text { updated } \\
\text { reference }\end{array}$ & $\begin{array}{c}\text { ACESA RPS } \\
\text { provision } \\
\text { only }\end{array}$ & $\begin{array}{c}\text { ACESA } \\
\text { RPS w/no } \\
\text { eff. credits }\end{array}$ & $\begin{array}{c}\text { ACESA } \\
\text { basic cap } \\
\text { and trade }\end{array}$ & $\begin{array}{c}\text { ACESA no } \\
\text { international/ } \\
\text { limited tech }\end{array}$ \\
\hline Coal & 602 & 527 & 509 & 215 & 72 \\
Oil & 20 & 20 & 19 & 18 & 18 \\
Gas & 279 & 246 & 243 & 174 & 535 \\
Nuclear & 371 & 357 & 338 & 770 & 368 \\
Pumped storage/other & 5 & 5 & 5 & 4 & 5 \\
$\quad$ Conventional hydropower & 36 & 36 & 36 & 37 & 38 \\
Geothermal & 0 & 0 & 0 & 0 & 0 \\
Biogenic municipal waste & 4 & 4 & 4 & 4 & 10 \\
Wood and other biomass & 50 & 160 & 193 & 79 & 52 \\
Solar thermal & 0 & 0 & 0 & 0 & 0 \\
Solar photovoltaic & 4 & 5 & 5 & 4 & 7 \\
Wind & 11 & 11 & 11 & 11 & 11 \\
Offshore wind & 0 & 0 & 0 & 0 & 13 \\
$\quad$ Total renewable & 104 & 216 & 249 & 134 & 132 \\
$\quad$ Total generation & 1305 & 1301 & 1292 & 1295 & 1130 \\
\hline
\end{tabular}




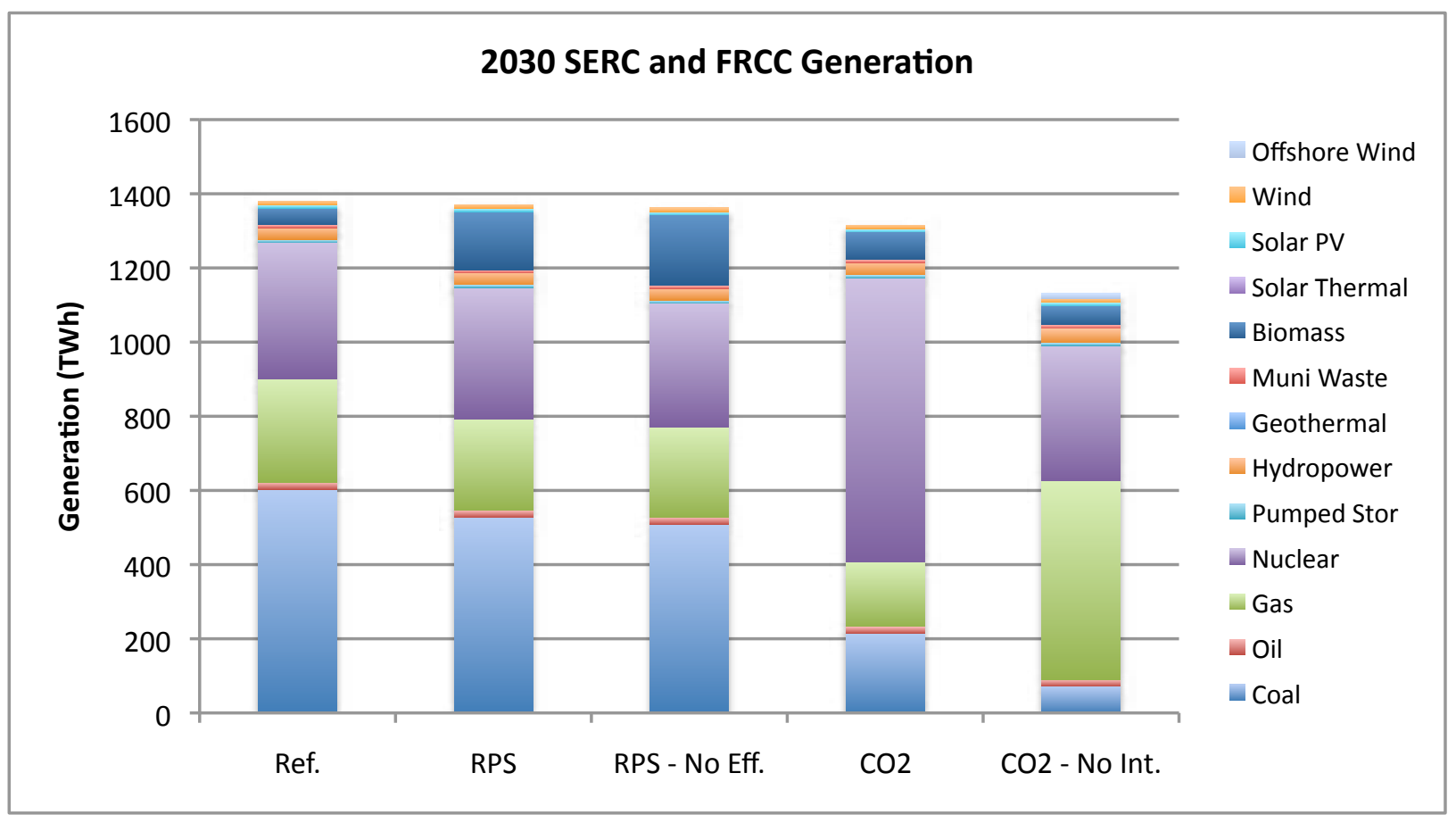

Fig. 2.6. Generation in 2030 for SERC and FRCC under different NEMS scenarios (TWhr).

at the expense of coal and gas. In the $\mathrm{CO}_{2}$ cap-and-trade scenario, nuclear power is the main replacement of coal and gas, although biomass does increase over the reference case. In the final scenario with no international credits and limited technology development, overall demand is reduced (due to price impacts and efficiency) while natural gas becomes the major new source of energy.

The amount of fossil fuels used in each scenario is shown in Table 2.5. The RPS scenarios reduce nuclear and fossil fuel by up to 1.5 Quads or $13 \%$ from the reference scenario. Using the fuel prices from the reference scenario, the reductions represent an annual cost savings for these fuels of almost $\$ 5$ billion in 2030. These funds would be used to purchase the additional renewable power (biomass, wind) that is used and/or fund the energy efficiency activities taking place, so net savings would be lower than this. Biomass fuel cost increases may be as high as $\$ 3$ billion, offsetting much of the fossil fuel savings.

Table 2.5. 2030 nuclear and fossil fuel use and percent change from reference scenario

\begin{tabular}{|c|c|c|c|c|c|c|c|c|c|}
\hline & \multirow{2}{*}{$\begin{array}{c}\text { AEO2009 } \\
\text { updated } \\
\text { reference } \\
\text { quad }\end{array}$} & \multicolumn{2}{|c|}{$\begin{array}{c}\text { ACESA RPS } \\
\text { provision only }\end{array}$} & \multicolumn{2}{|c|}{$\begin{array}{c}\text { ACESA RPS w/ } \\
\text { no eff. credits }\end{array}$} & \multicolumn{2}{|c|}{$\begin{array}{c}\text { ACESA basic } \\
\text { cap \& trade }\end{array}$} & \multicolumn{2}{|c|}{$\begin{array}{c}\text { ACESA no } \\
\text { international/ } \\
\text { limited tech }\end{array}$} \\
\hline & & Quad & $\%$ & Quad & $\%$ & Quad & $\%$ & Quad & $\%$ \\
\hline Coal & 6.13 & 5.38 & $-12 \%$ & 5.19 & $-15 \%$ & 2.07 & $-66 \%$ & 0.67 & $-89 \%$ \\
\hline Gas & 1.93 & 1.70 & $-12 \%$ & 1.67 & $-14 \%$ & 1.24 & $-36 \%$ & 3.96 & $105 \%$ \\
\hline Oil & 0.19 & 0.19 & $0 \%$ & 0.19 & $-1 \%$ & 0.17 & $-9 \%$ & 0.18 & $-8 \%$ \\
\hline Nuclear & 3.71 & 3.57 & $-4 \%$ & 3.38 & $-9 \%$ & 7.70 & $108 \%$ & 3.68 & $-1 \%$ \\
\hline Total & 11.96 & 10.84 & $-9 \%$ & 10.42 & $-13 \%$ & 11.19 & $-6 \%$ & 8.50 & $-29 \%$ \\
\hline
\end{tabular}

\subsection{GREEN JOB OPPORTUNITIES}

As shown above, renewable power could expand greatly in the Southeast from its current low base. Besides the construction and ongoing operation of the generation plants themselves, a manufacturing base to provide the components could also improve the jobs prospects for the region. Two studies from the 
Renewable Energy Policy Project conclude that more than 32,000 jobs could be developed in the southeast for wind and solar manufacturing (Sterzinger and Svrcek, 2004; Sterzinger and Svrcek, 2005). Several states have strongly pursued development in renewable power. In Tennessee there are plans for construction of several solar panel manufacturing facilities as well as wind pylons. South Carolina has facilities for manufacturing wind turbine generators.

Renewable power, being small scale and diverse, often leads to greater ongoing local labor use than large, centralized facilities. A white paper by Nicholas Rigas of Eco Energy LLC and Clemson University states that, based upon the experience of Denmark in developing offshore wind, there could be 17 jobs per megawatt manufactured plus 5 jobs per megawatt installed over the life of a project. These are likely not permanent jobs for each year of the equipment but rather the cumulative jobs over its life. Regardless, there could be a significant benefits for the Southeast if renewable resources are expanded in the region.

\subsection{WEST-SOUTH-CENTRAL ANALYSIS}

The NESSIE and UPLAN analysis described above focused largely on the renewable resources in the Southeast, but the companion to this study on energy efficiency includes an analysis of Texas and Oklahoma as well. Below is a brief overview of the amounts of renewables projected for these regions in the EIA NEMS analyses and NREL ReEDS analysis. It reports on the electricity resources in the Electric Reliability Council of Texas (ERCOT) and Southwest Power Pool (SPP) regions and so cover not only Texas and Oklahoma but also Kansas and parts of Arkansas, Louisiana, Colorado, and New Mexico as well (Fig. 2.1).

These regions have renewable resource profiles that are very different from the Southeast. Most notably, they have high amounts of wind resources, plus some solar and biomass resources. The difficulty in considering these resources available in the whole of the South is the lack of transmission capability from these western regions to SERC and FRCC. In fact, that problem was the reason for the NESSIE and UPLAN analyses that provided the previous data. Most of Texas is on a separate transmission grid with only small, expensive linkages to SPP and the West. While SPP linkages are more extensive, they are dwarfed by the amount renewable resource potential in the region.

The generating capacities developed by 2030 in the ERCOT and SPP regions in the different NEMS runs used above are shown in Table 2.6. Comparing this to Table 2.1 shows much higher wind resource development than the Southeast in all cases.

Table 2.6. ERCOT and SPP 2030 generating capacities under different NEMS runs (GW)

\begin{tabular}{|c|c|c|c|c|c|}
\hline & $\begin{array}{c}\text { AEO } 2009 \\
\text { updated } \\
\text { reference }\end{array}$ & $\begin{array}{c}\text { ACESA RPS } \\
\text { provision } \\
\text { only }\end{array}$ & $\begin{array}{l}\text { ACESA RPS } \\
\text { w/no eff. } \\
\text { credits }\end{array}$ & $\begin{array}{c}\text { ACESA } \\
\text { basic cap \& } \\
\text { trade }\end{array}$ & $\begin{array}{c}\text { ACESA no } \\
\text { international/ } \\
\text { limited tech }\end{array}$ \\
\hline Coal & 45 & 44 & 44 & 50 & 15 \\
\hline Oil and gas & 94 & 93 & 94 & 93 & 93 \\
\hline Nuclear & 7 & 7 & 7 & 19 & 7 \\
\hline Pumped storage/other & 1 & 1 & 1 & 1 & 1 \\
\hline Conventional hydropower & 3 & 3 & 3 & 3 & 3 \\
\hline Geothermal & 0 & 0 & 0 & 0 & 0 \\
\hline Biogenic municipal waste & 0 & 0 & 0 & 0 & 1 \\
\hline Wood and other biomass & 1 & 2 & 5 & 1 & 1 \\
\hline Solar thermal & 0 & 0 & 0 & 0 & 0 \\
\hline Solar photovoltaic & 2 & 2 & 2 & 2 & 3 \\
\hline Wind & 10 & 11 & 18 & 18 & 49 \\
\hline Offshore wind & 0 & 0 & 0 & 0 & 0 \\
\hline Total renewable & 16 & 18 & 28 & 23 & 57 \\
\hline Total generating capacity & 164 & 163 & 174 & 186 & 173 \\
\hline
\end{tabular}


The amount of generation by source dramatically changes based on the policies put into place. Under an RPS, the major change is the increase in biomass cofiring with coal, with some increase in wind generation (Fig. 2.7). With a carbon cap and trade, there is a decline in overall production. If new technologies are in place, then nuclear power expands greatly, wind power also grows, and coal production is reduced. If technology is limited and international credits are not allowed, then coal production essentially ceases, nuclear is not allowed to expand, and wind generation expands tremendously to meet the overall demands.

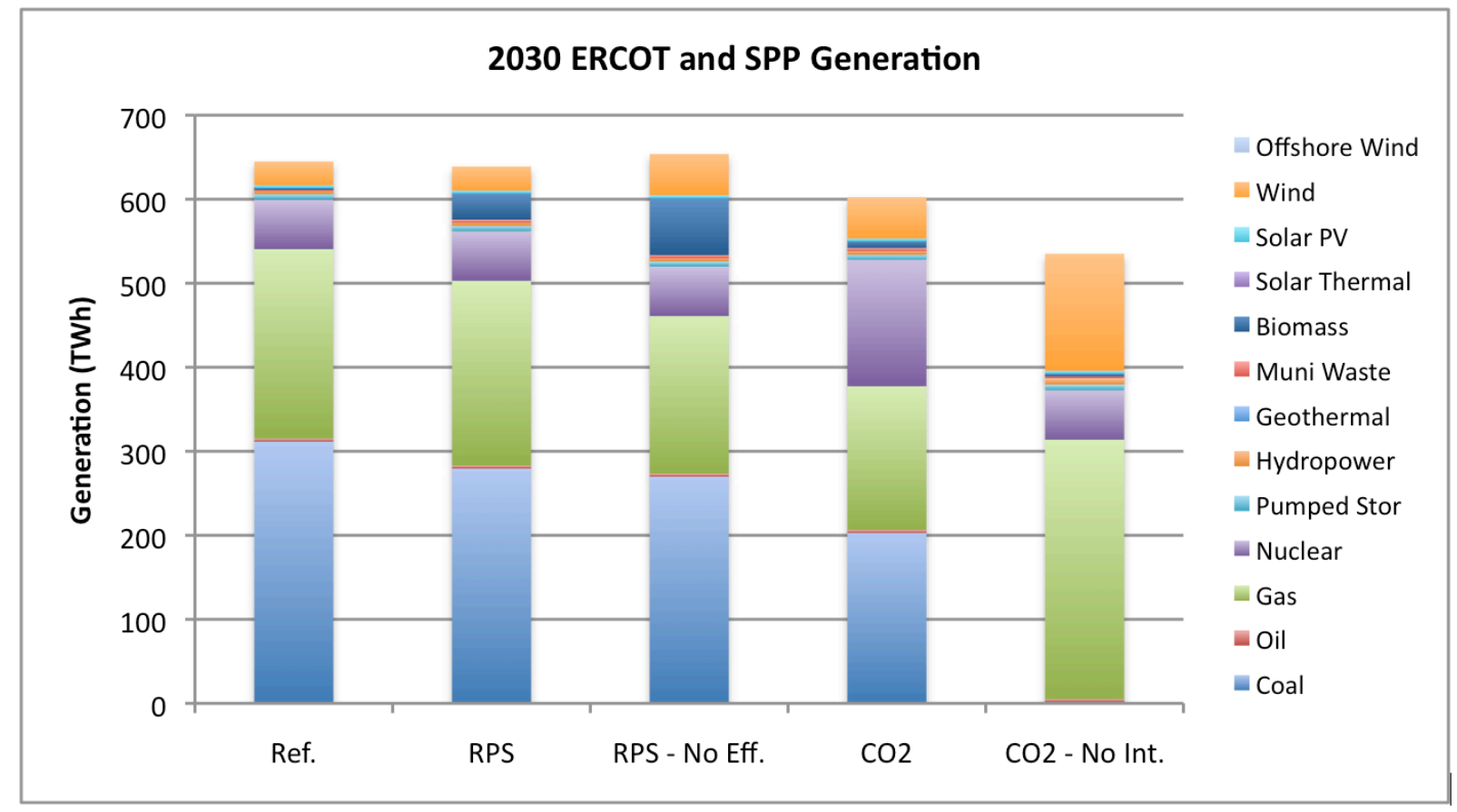

Fig. 2.7. Generation in 2030 for ERCOT and SPP under different NEMS scenarios (TWhr).

A study by NREL on RPS proposals (Sullivan, 2009) also includes state data for those states in the west-south-central regions and a table that shows the state-by-state generation by different renewable technologies (Table 2.7). Wind and solar development is much higher than under the NEMS analyses in Fig. 2.7, while the biomass amounts are much lower. This is likely due to the inclusion of biomass cofiring in the NEMS analysis. Total amounts of renewable generation in the NREL analysis fall between the amounts from the EIA analysis.

Table 2.7. West-south-central states' renewable generation in 2030 under Markey Bill (TWhr)

\begin{tabular}{lcccc}
\hline & Wind & Solar & Bio & Total \\
\hline Kansas & 12 & 1 & 1 & 14 \\
Oklahoma & 20 & 0 & 2 & 22 \\
Texas & 57 & 14 & 5 & 75 \\
$\quad$ Total & 89 & 15 & 7 & 112 \\
\multicolumn{5}{r}{ ERCOT + SPP from NEMS runs } \\
RPS & 29 & 3 & 32 & 71 \\
RPS-no eff. & 49 & 3 & 69 & 128 \\
\hline
\end{tabular}




\subsection{CONCLUSIONS}

Integration of renewable energy into the energy mix of the Southeast has multiple benefits. Among others, it provides a more diverse resource base to meet electricity demand, reduces the amount of imported fuels into the region, and provides jobs within the local economies.

Renewable energy expansion adds to the mix of energy sources used to provide electricity with fuels that are clean and sustainable. The current mix of fuels is dominated by coal, with roughly $50 \%$ of all generation. Natural gas and nuclear power also provide significant fractions. Currently hydropower is the major source of renewable energy in the South. As described in the following sections, there are several others that have potential for expansion.

This section reviewed a number of studies that have forecasted the potential contribution from various renewable energy sources. The models used all show different mixes, based on a combination of the input assumptions and the algorithms used in the model. Some only considered RPSs, while others included carbon cap and trade. Within those policies, the studies may have defined the portfolio standard differently, emphasized different technologies included, and to what or whether energy efficiency qualifies as a resource. Similarly, there are a number of different cap-and-trade parameters that could vary between studies.

Clearly, the answers are not going to be identical, but the general trends are examined in all the studies presented. However, assumptions regarding the technical viability of each resource can alter the outcomes significantly. For example, failure of offshore wind to develop or geothermal having a major breakthrough will alter the picture significantly. Similarly, greenhouse gas emission requirements greatly alter the outcomes and generation types used. Finally, the constraint posed by the 2030 study limit could effectively exclude technologies that may be significant contributors to a renewable penetration at a later date. Two very good examples are enhanced geothermal and next-generation offshore wind using dc transmission at distances greater than 20 miles out.

\subsection{REFERENCES}

EIA. 2009a. National Energy Modeling System: An Overview 2009, DOE/EIA-0581, U.S. Department of Energy, Washington, DC, October, http://www.eia.doe.gov/oiaf/aeo/overview/index.html

EIA. 2009b. An Updated Annual Energy Outlook 2009 Reference Case Reflecting Provisions of the American Recovery and Reinvestment Act and Recent Changes in the Economic Outlook, SR/OIAF/2009-03, Energy Information Administration, April, http://www.eia.doe.gov/oiaf/servicerpt/stimulus/index.html

EIA. 2009c. Impacts of a 25-Percent Renewable Electricity Standard as Proposed in the American Clean Energy and Security Act Discussion Draft, SR/OIAF/2009-04, Energy Information Administration, April, http://www.eia.doe.gov/oiaf/servicerpt/acesa/index.html

EIA. 2009d. Energy Market and Economic Impacts of H.R. 2454, the American Clean Energy and Security Act of 2009, SR/OIAF/2009-05, Energy Information Administration, August, http://www.eia.doe.gov/oiaf/servicerpt/hr2454/index.html

Hadley, Stanton W., Key, Thomas. 2009. Power Transfer Potential to the Southeast in Response to a Renewable Portfolio Standard: Interim Report 1, ORNL/TM-2008/222, Oak Ridge National Laboratory, March.

Hadley, Stanton W., Key, Thomas, Deb, Rajat Deb. 2009a. Power Transfer Potential to the Southeast in Response to a Renewable Portfolio Standard: Interim Report 2, ORNL/TM-2009/102, Oak Ridge National Laboratory, May. Hadley, Stanton W., Key, Thomas, Deb, Rajat. 2009b. Cascade Consulting Partners Power Transfer Potential to the Southeast in Response to a Renewable Portfolio Standard: Final Report, ORNL/TM-2009/239, Oak Ridge National Laboratory, November, http://info.ornl.gov/sites/ publications/Files/Pub21494.pdf 
Sterzinger, G., Svrcek, M. 2004. Wind turbine development: Location of manufacturing activity. Renewable Energy Policy Project (REPP), Washington, DC, September.

Sterzinger, G., Svrcek, M. 2005. Solar PV development: Location of economic activity. Renewable Energy Policy Project (REPP). January.

Sullivan, Patrick, Logan, Jeffrey, Bird, Lori, Short, Walter. 2009. Comparative Analysis of Three Proposed Federal Renewable Electricity Standards, NREL/TP-6A2-45877, National Renewable Energy Laboratory, May. 


\section{WIND ENERGY IN THE SOUTHEAST}

The 2009 Wind Technologies Market Report (EERE, 2009) analyzes a range of developments in the wind market, including trends in wind project installations, turbine size, turbine prices, wind project costs, project performance, and wind power prices. The report also details trends in project financing, a key concern for the wind industry in the current economic climate, as well as trends in project ownership, public policy, and the integration of wind power into the electrical grid. In addition, the report provides the wind industry, state and local policy makers, and the general public with valuable information on the state of wind power in the United States. This report and the wind resource maps present an up-to-date view of the status of wind energy in the United States.

\subsection{WIND ENERGY RESOURCE MAPS}

The wind power resources in the Southeast area are mostly in the Appalachian Mountains and offshore. West Virginia, Virginia, Kentucky, Tennessee, and North Carolina have some wind power resources in the mountains. Virginia, North Carolina, South Carolina, and Louisiana have outstanding wind power resources offshore. Georgia, Florida, Alabama, and Mississippi have largely fair-to-good wind power offshore. The original NREL resource maps for $50 \mathrm{~m}$ heights show relatively little wind power potential in the Southeast. Figure 3.1 is the national map for the resources at a $50 \mathrm{~m}$ hub height. It includes both the onshore and offshore wind potential by class.

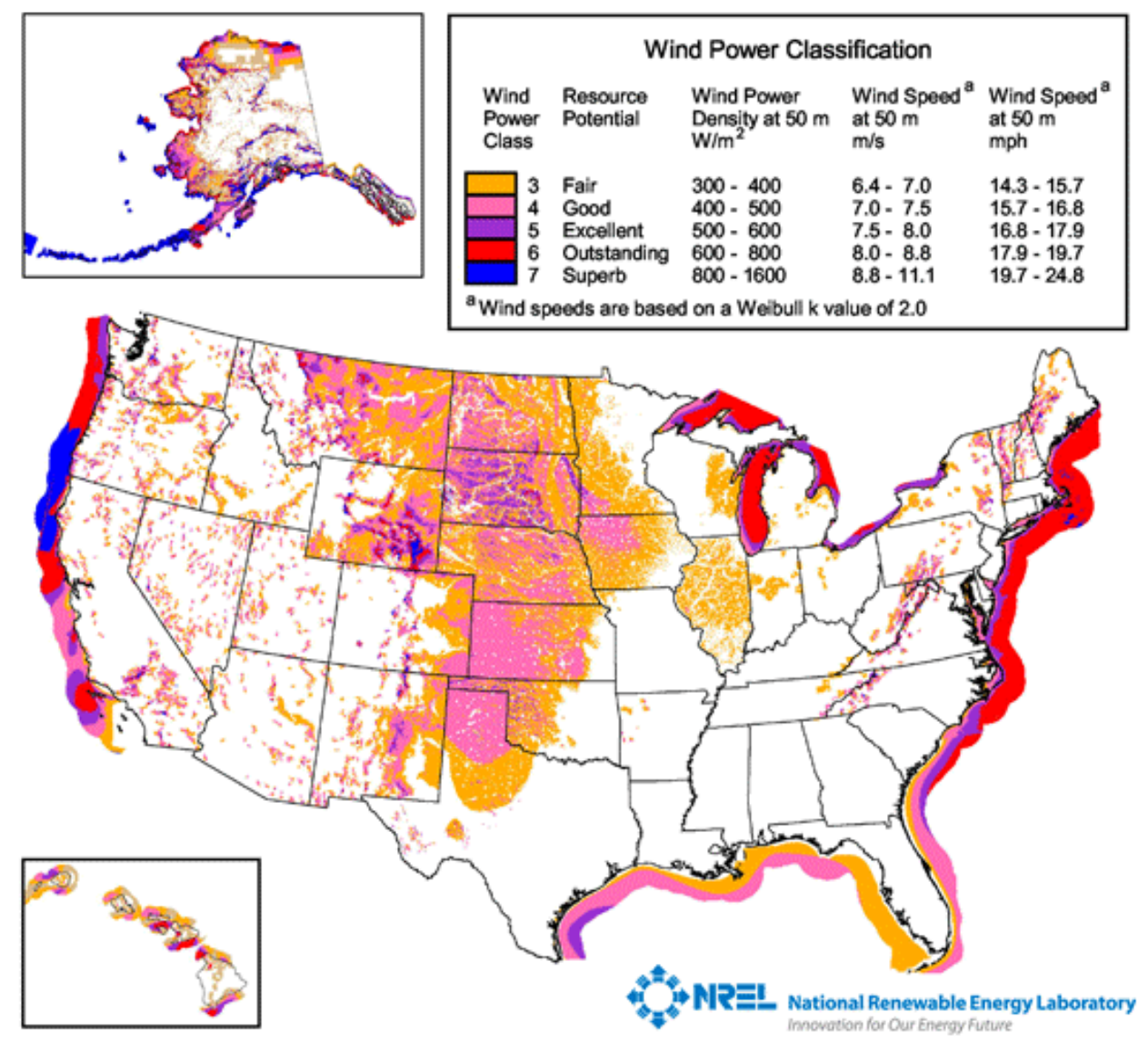

Fig. 3.1. National wind resources at $50 \mathrm{~m}$. Source: DOE/EERE http://www1.eere.energy.gov/windandhydro/wind_potential.html. 
The newer $80 \mathrm{~m}$ data show much more favorable resources. The maps and data resources at an $80 \mathrm{~m}$ hub height maps for each state in the study are included in Appendix A. These maps only include resource profiles for the onshore wind capabilities. The resource maps are extracted from the national NREL report available at Windpowering America web site (EERE, 2011). More recent offshore maps at the $90 \mathrm{~m}$ hub height are found at the same source are also included. It is clear from these offshore data that a major wind energy resource lies just off the coasts of Georgia, Louisiana, North Carolina, South Carolina, and Virginia. Links to the Proceedings of the Southeast Regional Offshore Wind Power Symposium provide a more detailed review of the status and potential for offshore wind in the Southeast.

Table 3.1, extracted from the NREL national report, shows wind potential for the expanded southeastern states, the windy land area with a gross capacity factor (without losses) of $30 \%$ and greater at a $80 \mathrm{~m}$ height above the ground and the wind energy potential from development of the "available" windy land area after exclusions.

The "installed capacity" shows the potential megawatts of rated capacity that could be installed on the available windy land area, and the "annual generation" shows annual wind energy.

Table 3.1. Wind potential for the expanded southeastern states extracted from the NREL national report (http://www.windpoweringamerica.gov/) ${ }^{a}$

\begin{tabular}{|c|c|c|c|c|c|c|c|}
\hline \multirow[b]{2}{*}{ State } & \multicolumn{5}{|c|}{ Windy land area $\geq 30 \%$ gross capacity factor at $80 \mathrm{~m}$} & \multicolumn{2}{|c|}{ Wind energy potential } \\
\hline & $\begin{array}{l}\text { Windy } \\
\text { total } \\
\left(\mathrm{km}^{2}\right)\end{array}$ & $\underset{\left(\mathrm{km}^{2}\right)}{\text { Excluded }^{b}}$ & $\begin{array}{c}\text { Available } \\
\left(\mathrm{km}^{2}\right)\end{array}$ & $\begin{array}{l}\text { Available } \\
\text { as \% of } \\
\text { state land } \\
\text { area } \\
(\%)\end{array}$ & $\begin{array}{c}\% \text { of } \\
\text { total } \\
\text { windy } \\
\text { land } \\
\text { excluded } \\
(\%)\end{array}$ & $\begin{array}{l}\text { Maximum } \\
\text { installed } \\
\text { wind } \\
\text { capacity }^{c} \\
(G W)\end{array}$ & $\begin{array}{c}\text { Maximum } \\
\text { annual } \\
\text { generation } \\
\text { (TWhr) }\end{array}$ \\
\hline Alabama & 80.4 & 56.7 & 23.6 & 0.02 & 70.6 & 0.1 & 0 \\
\hline Arkansas & $4,663.2$ & $2,823.2$ & $1,840.1$ & 1.34 & 60.5 & 9.2 & 32 \\
\hline Florida & 9.6 & 9.5 & 0.1 & 0.00 & 99.2 & 0.0 & 0 \\
\hline Georgia & 281.3 & 255.3 & 26.0 & 0.02 & 90.7 & 0.1 & 0 \\
\hline Kentucky & 48.7 & 36.6 & 12.1 & 0.01 & 75.1 & 0.1 & 0 \\
\hline Louisiana & 125.5 & 43.6 & 82.0 & 0.07 & 34.7 & 0.4 & 1 \\
\hline Maryland & 567.7 & 271.1 & 296.6 & 1.18 & 47.8 & 1.5 & 5 \\
\hline Mississippi & 0.0 & 0.0 & 0.0 & 0.00 & N/A & 0.0 & 0 \\
\hline Missouri & $69,676.8$ & $14,805.8$ & $54,871.0$ & 30.39 & 21.2 & 274.4 & 961 \\
\hline Oklahoma & $123,243.6$ & $19,879.2$ & $103,364.4$ & 57.10 & 16.1 & 516.8 & 1,811 \\
\hline North Carolina & $1,155.6$ & 994.1 & 161.5 & 0.13 & 86.0 & 0.8 & 3 \\
\hline South Carolina & 102.8 & 65.8 & 37.0 & 0.05 & 64.0 & 0.2 & 1 \\
\hline Tennessee & 359.9 & 298.1 & 61.9 & 0.06 & 82.8 & 0.3 & 1 \\
\hline Texas & $435,638.6$ & $55,332.7$ & $380,305.9$ & 55.54 & 12.7 & $1,901.5$ & 6,663 \\
\hline Virginia & $1,567.2$ & $1,208.5$ & 358.7 & 0.35 & 77.1 & 1.8 & 6 \\
\hline West Virginia & $1,495.2$ & $1,118.6$ & 376.6 & 0.60 & 74.8 & 1.9 & 7 \\
\hline $\begin{array}{l}\text { Extended SE } \\
\text { totals }\end{array}$ & $639,016.3$ & $97,198.8$ & $541,817.5$ & 23.09 & 15.21 & $2,709.1$ & $9,492.6$ \\
\hline SE total ${ }^{d}$ & $9,889.5$ & $6,909.9$ & $2,979.6$ & 0.23 & 69.87 & 14.9 & 52.2 \\
\hline
\end{tabular}

${ }^{a}$ NREL's wind potential estimates were based on maps produced by AWS Truewind using the MesoMap ${ }^{\circledR}$ system.

${ }^{b}$ Excluded lands include protected lands (national parks, wilderness, etc.), incompatible land use (urban, airports, wetland, and water features), and other considerations. See Table 1 in the full report for full listing.

${ }^{c}$ Assumes $5 \mathrm{MW} / \mathrm{km}^{2}$ of installed nameplate capacity.

${ }^{d}$ Excludes Maryland, Missouri, Oklahoma, and Texas. 
generation in terawatt-hours that could be produced from the installed capacity. AWS Truewind, LLC developed the wind resource data for windNavigator ${ }^{\circledR}$ with a spatial resolution of $200 \mathrm{~m}$. NREL produced the estimates of windy land area and windy energy potential, including filtering the estimates to exclude areas unlikely to be developed such as wilderness areas, parks, urban areas, and water features.

These estimates show, for each of the southeastern states, the extended southeastern states totals, and the Southeast totals, the windy land area with a gross capacity factor (without losses) of $30 \%$ and greater at $80 \mathrm{~m}$ height above the ground and the wind energy potential from development of the "available" windy land area after exclusions. The "installed capacity" shows the potential megawatts of rated capacity that could be installed on the available windy land area, and the "annual generation" shows annual wind energy generation in gigawatt-hours that could be produced from the installed capacity. AWS Truewind, LLC developed the wind resource data for windNavigator ${ }^{\circledR}$ (http://navigator.awstruewind.com) with a spatial resolution of $200 \mathrm{~m}$. NREL produced the estimates of windy land area and windy energy potential, including filtering the estimates to exclude areas unlikely to be developed such as wilderness areas, parks, urban areas, and water features. Additional information is provided in Table 3.2.

Table 3.2. Wind resource exclusions

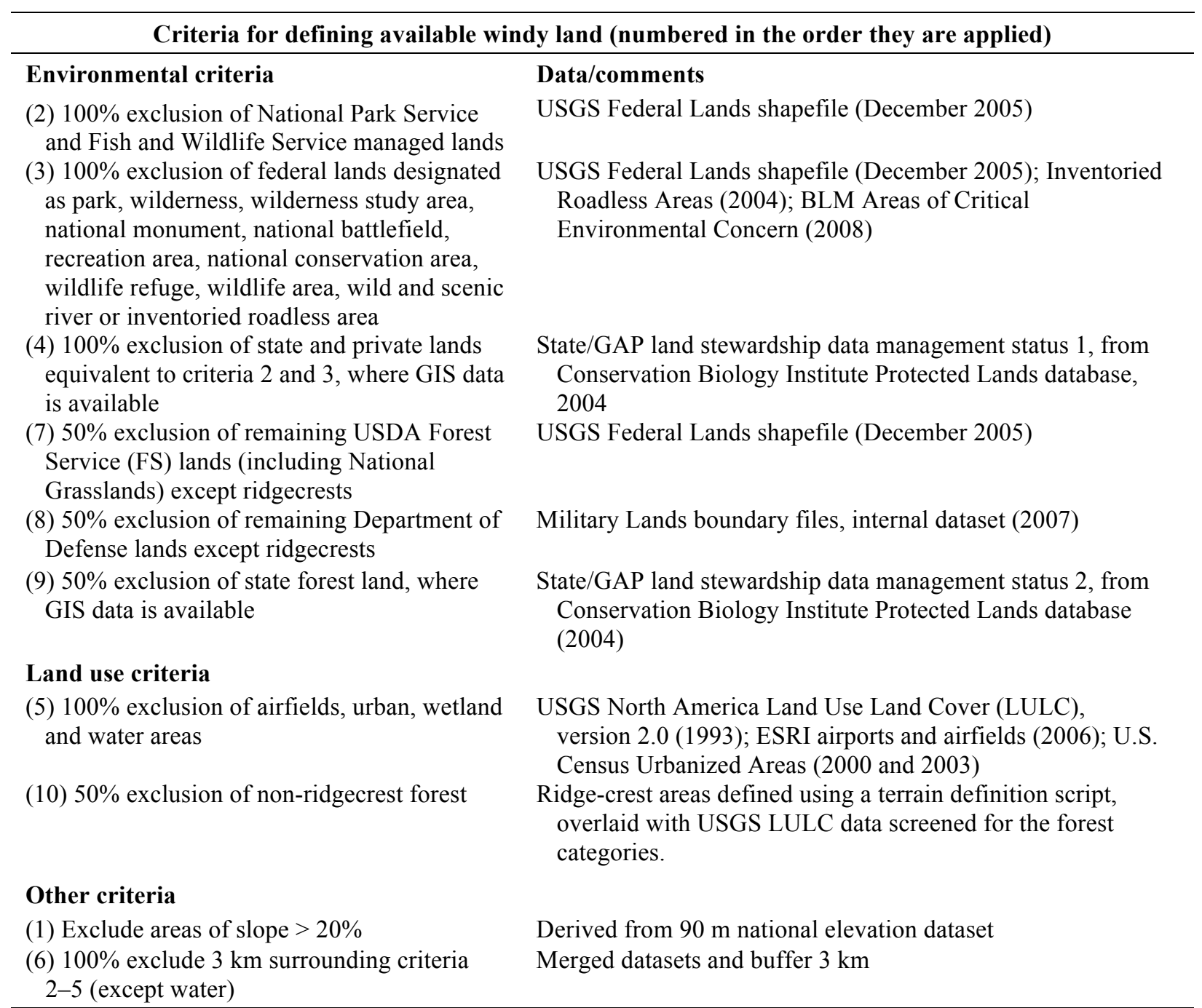

Note: $50 \%$ exclusions are not cumulative. If an area is non-ridgecrest forest on FS land, it is just excluded at the $50 \%$ level one time. 
Clearly without transmission access to the wind resources from the extended southeastern states (Missouri, Oklahoma, and Texas), the onshore potential for wind generation in the Southeast is limited. This is primarily because only $0.23 \%$ of the land area is available for wind generation after exclusions. Even without exclusions, only a little over $1 \%$ of land area is viable.

Another way to look at the wind potential of the Southeast is shown in Table 3.3, which limits wind capacity to $25 \%$ of installed capacity for stability reasons. The issue is essentially a non-problem since most southeastern states do not have sufficient wind potential after exclusions to even remotely approach $25 \%$ of total installed capacity. The comparison should ultimately exclude base load capacity, but even then few states approach the $25 \%$ criteria.

Table 3.3. Wind potential extended southeastern states as fraction of presently installed capacity

\begin{tabular}{|c|c|c|c|c|c|c|}
\hline State & $\begin{array}{l}\text { Total gen. } \\
\text { capacity } \\
\text { in GW }\end{array}$ & $\begin{array}{c}\text { Annual } \\
\text { generation } \\
\text { (TWhr) }\end{array}$ & $\begin{array}{c}\text { Potential } \\
\text { installed wind } \\
\text { capacity in GW } \\
\text { stability limit } \\
(25 \%) \text { of base } \\
\end{array}$ & $\begin{array}{l}\text { Net wind gen. } \\
\text { in TWhr under } \\
\text { stability limit } \\
\text { at } 40 \% \mathrm{CF}\end{array}$ & $\begin{array}{c}\text { Max installed } \\
\text { capacity in } \\
\text { GW after } \\
\text { exclusion or } \\
\text { stability limit }\end{array}$ & $\begin{array}{c}\text { \% wind } \\
\text { TWhr }\end{array}$ \\
\hline Alabama & 31.2 & 145.9 & 7.8 & 0.4 & 0.1 & $0.3 \%$ \\
\hline Arkansas & 15.3 & 55.1 & 3.8 & 13.4 & 3.8 & $24.3 \%$ \\
\hline Florida & 55.5 & 219.6 & 13.9 & 0.0 & 0.0 & $0.0 \%$ \\
\hline Georgia & 36.5 & 136.2 & 9.1 & 0.5 & 0.1 & $0.3 \%$ \\
\hline Kentucky & 19.9 & 97.9 & 5.0 & 0.2 & 0.1 & $0.2 \%$ \\
\hline Louisiana & 26.2 & 92.5 & 6.6 & 1.4 & 0.4 & $1.6 \%$ \\
\hline Maryland & 12.6 & 47.4 & 3.2 & 5.2 & 1.5 & $11.0 \%$ \\
\hline Mississippi & 15.9 & 48.2 & 4.0 & - & 0.0 & - \\
\hline Missouri & 20.7 & 91.0 & 5.2 & 18.1 & 5.2 & $19.9 \%$ \\
\hline $\begin{array}{l}\text { Oklahoma } \\
\text { North }\end{array}$ & 20.3 & 76.3 & 5.1 & 17.8 & 5.1 & $23.3 \%$ \\
\hline & 27.7 & 125.2 & 6.9 & 2.8 & 0.8 & $2.3 \%$ \\
\hline Carolina & 24.0 & 101.0 & 6.0 & 0.6 & 0.2 & $0.6 \%$ \\
\hline Tennessee & 20.9 & 90.7 & 5.2 & 1.1 & 0.3 & $1.2 \%$ \\
\hline Texas & 105.0 & 404.8 & 26.3 & 92.0 & 26.3 & $22.7 \%$ \\
\hline $\begin{array}{l}\text { Virginia } \\
\text { West }\end{array}$ & 23.5 & 72.7 & 5.9 & 6.3 & 1.8 & $8.6 \%$ \\
\hline Virginia & 16.3 & 91.1 & 4.1 & 6.6 & 1.9 & $7.2 \%$ \\
\hline Totals & 471.5 & $1,895.6$ & 117.9 & 166.5 & 47.5 & $8.8 \%$ \\
\hline SE total & 312.9 & $1,276.1$ & 78.2 & 33.4 & 9.5 & $2.6 \%$ \\
\hline
\end{tabular}

If sufficient transmission capacity is available to move energy from Missouri, Oklahoma, and Texas, the onshore wind potential for the southeastern states is $166.5 \mathrm{GW}$ (35.3\% of installed present capacity). Without this extended states input, the southeastern states can only reach $33.4 \mathrm{GW}(10.6 \%$ of presently installed capacity) with all onshore wind developed. If all capacity generates at $40 \%$ capacity factor, the energy produced, as a fraction of fully loaded present capacity, is nominally $8.8 \%$ for the extended states and $2.6 \%$ for the base southeastern states.

Now consider offshore wind energy estimates. Extracting the extended southeastern states from the offshore wind tables in Appendix A, one immediately sees that the offshore wind potential is much larger and perhaps more easily accessed (Tables 3.4 and 3.5). While there is little direct U.S. experience with offshore wind systems, building upon experience from offshore oil and gas drilling platforms and 
Table 3.4. Offshore wind resource area by state with potential by wind speed interval to 50 nautical miles from shore

\begin{tabular}{|c|c|c|c|c|c|c|c|}
\hline \multirow[b]{2}{*}{ State } & \multicolumn{7}{|c|}{ Wind speed at $90 \mathrm{~m}(\mathrm{~m} / \mathrm{sec})$} \\
\hline & $\begin{array}{l}7.0-7.5 \\
\text { (MW) }\end{array}$ & $\begin{array}{c}7.5-8.0 \\
\text { (MW) }\end{array}$ & $\begin{array}{c}8.0-8.5 \\
(M W)\end{array}$ & $\begin{array}{c}8.5-9.0 \\
\text { (MW) }\end{array}$ & $\begin{array}{l}9.0-9.5 \\
\text { (MW) }\end{array}$ & $\begin{array}{c}\text { Total }>7.0 \\
(\text { MW) }\end{array}$ & $\begin{array}{c}\text { TWhr at } \\
40 \% \\
\text { (CF) }\end{array}$ \\
\hline Georgia & 19,100 & 38,705 & 2,615 & 0 & 0 & 60,420 & 212 \\
\hline Louisiana & 240,215 & 75,160 & 0 & 0 & 0 & 315,375 & 1,105 \\
\hline Maryland & 10,960 & 9,730 & 7,700 & 25,390 & 0 & 53,780 & 188 \\
\hline $\begin{array}{l}\text { North } \\
\text { Carolina }\end{array}$ & 9,235 & 20,490 & 68,275 & 199,375 & 80 & 297,455 & 1,042 \\
\hline $\begin{array}{l}\text { South } \\
\text { Carolina }\end{array}$ & 7,285 & 41,010 & 51,920 & 30,035 & 0 & 130,250 & 456 \\
\hline Texas & 10,095 & 124,115 & 82,780 & 61,365 & 0 & 278,355 & 975 \\
\hline Virginia & 4,445 & 18,290 & 32,745 & 38,970 & 0 & 94,450 & 331 \\
\hline Total & 301,335 & 327,500 & 246,035 & 355,135 & 80 & $1,230,085$ & 4,310 \\
\hline SE total & 280,280 & 193,655 & 155,555 & 268,380 & 80 & 897,950 & 3,146 \\
\hline
\end{tabular}

Table 3.5. Southeast offshore wind resource based on distance from shore

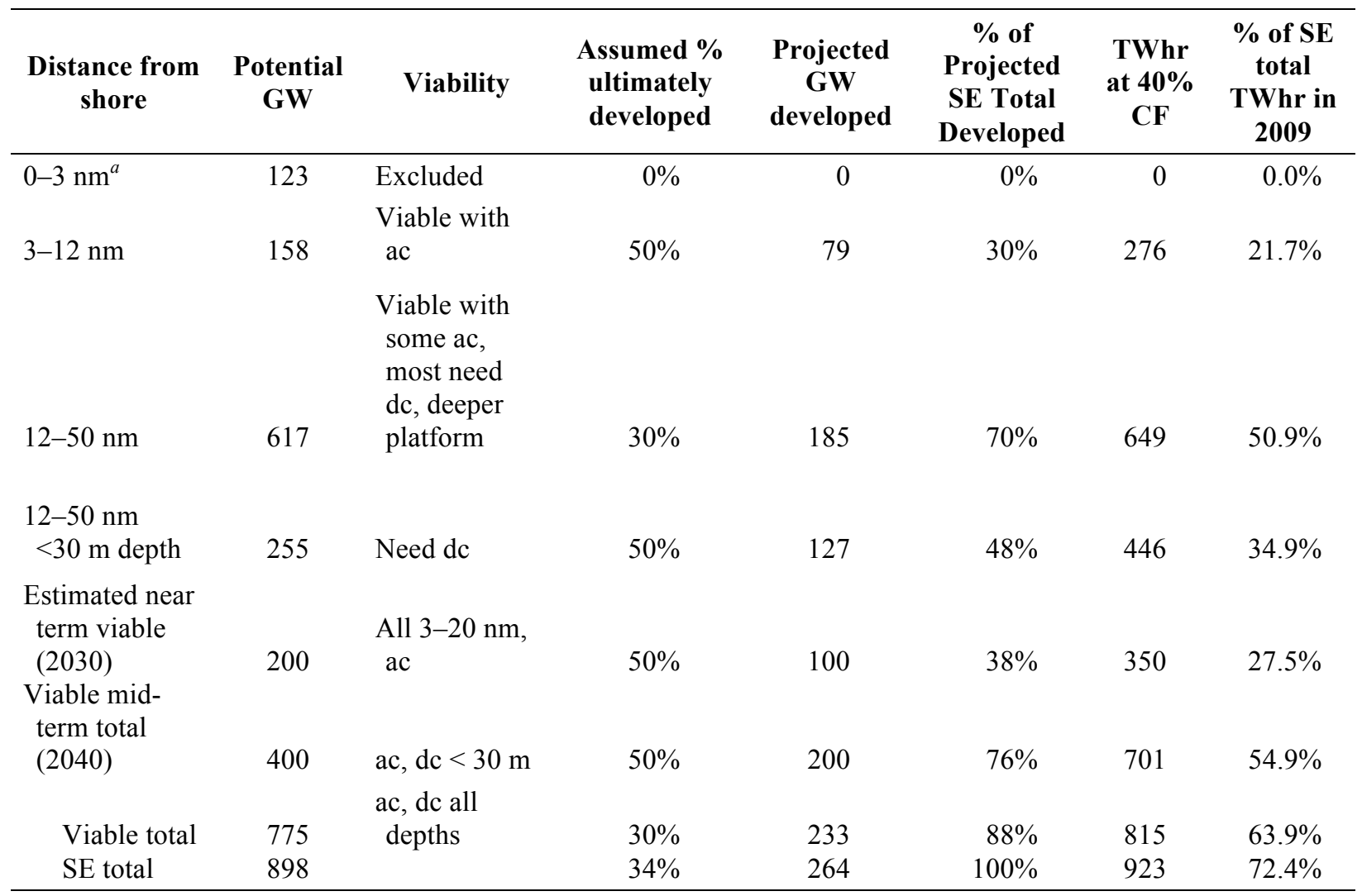

${ }^{a} \mathrm{~nm}=$ nautical miles 
European knowledge of offshore wind, submarine ac and dc cable technology, and advanced wind turbines, it should be possible to rapidly build a network to harness the wind potential that lies just off the U.S. coast.

Because of the structural materials needed to reach the seafloor, the use of undersea cables (both ac and dc), and the use of larger wind machines, offshore wind plant capital costs will by nature be more expensive. However, good offshore resources will enable a nominal $5 \mathrm{MW} / \mathrm{km}^{2}$ with capacity factors of $40-50 \%$ (Tables 3.4 and 3.5).

What is not shown is the effect of distance for shore and water depth. The second resource (table in Appendix A) allows such a comparison by breaking the resource into $0-3,3-12$, and $12-50 \mathrm{~nm}$ distance from shore (0-9 and 9-12 nm for Texas).

Note that offshore development presents additional concerns for development.

1. Distance from shore may reduce the number of permits required since, with the exception of Texas $(9 \mathrm{~nm})$, federal authority begins at $3 \mathrm{~nm}$.

2. Distance from shore results in increased length of undersea cable runs and for distances greater than a nominal $20 \mathrm{~nm}$ dc transmission is generally required, which increases the cost of installations.

Unfortunately, there are no U.S. suppliers, and ABB and Siemens supply the available dc systems. In addition, multi-terminal dc which must be developed are required.

3. Water depths, while for the southeastern states are less than $60 \mathrm{~m}$ out to $50 \mathrm{~nm}$, do present added costs. Depths greater than $60 \mathrm{~m}$ are about $20 \%$ of the resource and almost $60 \%$ of the resource is found at depths of $30 \mathrm{~m}$ or less. Fortunately, the vast majority $(80 \%)$ of the Southeast offshore potential is in depths less than $60 \mathrm{~m}$. Moreover, as a result of offshore drilling operations, significant offshore experience is available, which should speed development and limit increased cost.

Table 3.5 clearly establishes the need for offshore wind in any SE renewable portfolio. By 2030, offshore wind alone using only ac cables could supply a nominal $100 \mathrm{GW}$ of capacity producing $350 \mathrm{TWhr}$ annually or $27.5 \%$ of 2009 generation in the southeastern states. Assuming that only $34 \%$ of the area beyond $3 \mathrm{~nm}$ is developed, the resource could ultimately provide $264 \mathrm{GW}$ of capacity and $923 \mathrm{TWhr}$ of energy annually.

\subsubsection{Wind Energy Costs}

In the early $1980 \mathrm{~s}$, when the first utility-scale turbines were installed, wind-generated electricity cost as much as 30 cents $/ \mathrm{kWhr}$. Now, state-of-the-art wind power plants can generate electricity for less than 5 cents $/ \mathrm{kWhr}$ with the production tax credit (PTC) in many parts of the United States, a price that is competitive with new coal- or gas-fired power plants.

Wind technology is competitive today in bulk power markets with support from the PTC, and in highvalue niche applications or markets that recognize non-cost attributes. Current performance is characterized by levelized costs of 4 to 5.5 cents/kWhr (depending on resource intensity and financing structure), capacity factors of 30 to $40 \%$, availability of 95 to $98 \%$, total installed project costs ("overnight"- not including construction financing) of $\$ 800$ to $\$ 1,100 / \mathrm{kW}$, and efficiencies of $65 \%$ to $75 \%$ of the theoretical (Betz limit) maximum.

The worldwide annual market growth rate for wind technology is about $30 \%$, with new markets opening in countries throughout the world. Domestic public interest in environmentally responsible electric generation technology is reflected by new state energy policies and in the success of "green marketing" of wind power across the country.

The economics of wind energy has changed dramatically over the past 20 years, as the cost of wind power has fallen approximately $90 \%$ during that period. Despite this progress, the wind industry is still somewhat immature, with production volumes still fluctuating. Thus, the factors affecting the cost of 
wind energy are still rapidly changing, and the cost of wind energy will continue to decline as the industry grows and matures.

A number of factors determine the economics of utility-scale wind energy and its competitiveness in the energy marketplace.

1. The cost of wind energy varies widely depending upon the wind speed at a given project site. The energy that can be tapped from the wind is proportional to the cube of the wind speed, so a slight increase in wind speed results in a large increase in electricity generation. Consider two sites, one with an average wind speed of $14 \mathrm{miles} / \mathrm{hr}(\mathrm{mph})$ and the other with average winds of $16 \mathrm{mph}$. All other things being equal, a wind turbine at the second site will generate nearly $50 \%$ more electricity than it would at the first location. The three examples in Fig. 3.2 show cost per kilowatt-hour for a $51 \mathrm{MW}$ wind farm at three different average wind speeds expressed in meters per second. Cost figures include a wind PTC.

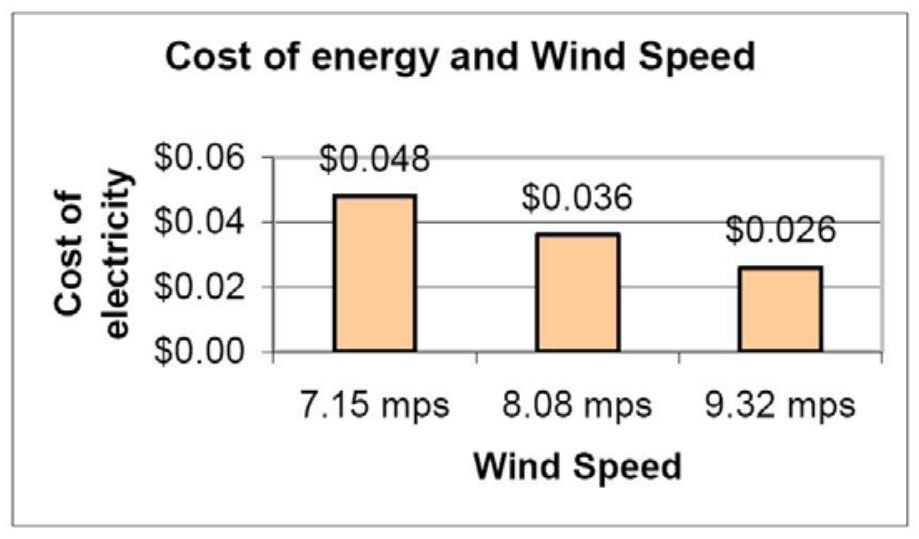

Fig. 3.2. Cost of energy and wind speed.

2. Improvements in turbine design bring down costs. The taller the turbine tower and the larger the area swept by the blades, the more powerful and productive the turbine. The swept area of a turbine rotor (a circle) is a function of the square of the blade length (the circle's radius). Therefore, a fivefold increase in rotor diameter (from $10 \mathrm{~m}$ on a $25 \mathrm{~kW}$ turbine like those built in the $1980 \mathrm{~s}$ to $50 \mathrm{~m}$ on a $750 \mathrm{~kW}$ turbine common today) yields a 55 -fold increase in yearly electricity output, partly because the swept area is 25 times larger and partly because the tower height has increased substantially, and wind speeds increase with distance from the ground. Advances in electronic monitoring and controls, blade design, and other features have also contributed to a drop in cost. Table 3.6 shows how a modern 1.65 MW turbine generates 120 times the electricity at one-sixth the cost of an older $25 \mathrm{~kW}$ turbine.

Table 3.6. Cost comparison of wind power in 1981 and 2000

\begin{tabular}{lll}
\hline \multicolumn{1}{c}{ Year } & \multicolumn{1}{c}{$\mathbf{1 9 8 1}$} & \multicolumn{1}{c}{$\mathbf{2 0 0 0}$} \\
\hline Rated capacity & $25 \mathrm{~kW}$ & $1,650 \mathrm{~kW}$ \\
Rotor diameter & $10 \mathrm{~m}$ & $71 \mathrm{~m}$ \\
Total cost & $\$ 65,000$ & $\$ 1,300,000$ \\
Cost $/ \mathrm{kW}$ & $\$ 2,600$ & $\$ 790$ \\
Output, $\mathrm{kWhr} /$ year & 45,000 & 5.6 million \\
\hline
\end{tabular}


3. A large wind farm is more economical than a small one. Assuming the same average wind speed of $18 \mathrm{mph}$ and identical wind turbine sizes, a $3 \mathrm{MW}$ wind project delivers electricity at a cost of $\$ 0.059 / \mathrm{kWhr}$ and a $51 \mathrm{MW}$ project delivers electricity at $\$ 0.036 / \mathrm{kWhr}$ - a drop in costs of $\$ 0.023$, or nearly $40 \%$. Any project has transaction costs that can be spread over more kilowatt-hours with a larger project. Similarly, a larger project has lower O\&M (operations and maintenance) costs per kilowatt-hour because of the efficiencies of managing a larger wind farm. The costs of energy produced by a large wind farm versus a small one are shown in Fig. 3.3. Cost figures include the current wind PTC.

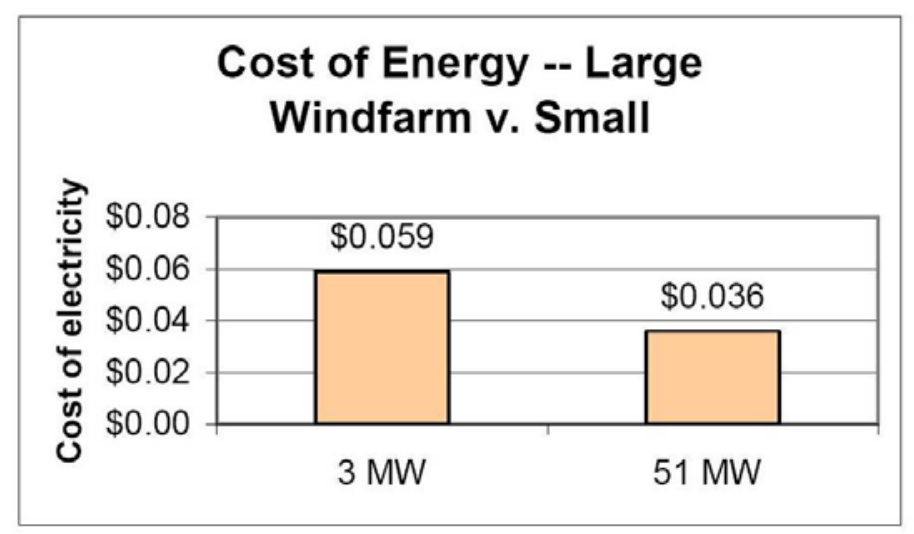

Fig. 3.3. Cost of energy—large wind farm vs small.

4. Optimal configuration of the turbines to take the best advantage of micro-features on the terrain will also improve a project's productivity (Germain and Dain, 1997).

5. The cost of financing affects the cost of wind energy. Wind energy is capital intensive, so the cost of financing constitutes a large variable in a wind energy project's economics. For a variety of reasons, financing for wind projects remains more expensive than for mainstream forms of electricity generation.

Project ownership affects cost of financing and the economics of a wind power project. Independent ownership - that is, financing of projects by private power producers on a stand-alone basis, which is how the vast majority of U.S. wind projects are financed - is more expensive than utility-owned financing. According to a study by Lawrence Berkeley National Laboratory(Wiser and Kahn, 1996), utility ownership of a wind facility results in a significantly lower estimated levelized cost of energy, because lower-cost financing available to large electric utilities (IOUs, or investor-owned utilities) is not available for non-IOU wind projects. IOU ownership reduces levelized costs by approximately $30 \%$, the study found.

In addition, although wind turbine technology has steadily progressed to a point where its reliability is today comparable to that of other energy technologies, it is still regarded as novel and risky by many members of the U.S. financial community (most U.S. projects are still financed by European-based lenders). Lenders therefore offer less favorable financing terms and demand a higher return on investment than for more conventional energy sources.

The Lawrence Berkeley Laboratory study found that a $50 \mathrm{MW}$ wind farm delivering power at just under 5 cents/kWhr would, if using typical natural-gas-project financing terms, generate electricity for 3.69 cents/kWhr (Table 3.7). 
Table 3.7. The economics of a $50 \mathrm{MW}$ wind farm at a wind site with average wind speed of 13-17 mph (class 4)

\begin{tabular}{ll}
\hline Project size & $50 \mathrm{MW}$ \\
Capital cost & $\$ 65$ million $(\$ 1.3$ million/MW) \\
Annual power production (assuming & 150 million $\mathrm{kWhr}$ \\
$35 \%$ capacity factor) & \\
Financing & $60 \% \mathrm{debt}, 40 \%$ equity \\
Annual gross revenue & $\$ 6$ million $($ assuming power purchase price of \\
& 4 cents/ $\mathrm{kWhr})$ \\
Expenses & Debt: $60 \%(15$ years at $9.5 \%)$ \\
& Distribution, $22 \%$ \\
& Operation and maintenance, $8 \%$ \\
& Land, property taxes, or rent, $5 \%$ \\
& Mgt. fees and insurance, $5 \%$ \\
Tax credit and depreciation & 5 year depreciation on wind equipment \\
& 1.5 cents/ $\mathrm{kWh}$ credit adjusted for inflation during \\
& first 10 years of operation \\
\hline
\end{tabular}

6. Transmission, tax, environmental, and other policies also affect the economics of wind. Transmission and market access constraints can significantly affect the cost of wind energy. Since wind speeds vary, wind plant operators cannot perfectly predict the amount of electricity they will be delivering to transmission lines in a given hour. Deviations from schedule are often penalized without regard to whether they increase or decrease system costs. Interconnection procedures are not standardized, and utilities have on occasion imposed such difficult and burdensome requirement on wind plants for connection to transmission lines that wind companies have chosen to build their own lines instead. As electricity markets are restructured and long-term power purchase agreements give way to trading on power exchanges, transmission and market access conditions will play an increasingly important role in the economics of a wind project.

The federal tax code, which provides a variety of permanent and temporary incentives for conventional forms of energy, also includes a PTC for wind energy and a 5 year accelerated depreciation schedule for wind turbines. The 1.5 cent-per-kWh PTC is adjusted for inflation (currently it stands at 1.8 cents/ $\mathrm{kWhr}$ ) and supports electricity generated from utility-scale wind turbines for the first 10 years of their operation. The PTC, first adopted in 1992, was extended in 1999, again, through 2003 after its expiration in 2001, and most recently through December 31, 2005, after its expiration in 2004. In order to qualify for the credit, generators must now complete installations and start production before the 2005 expiration date. The PTC may be reduced or cancelled if a project applies for state incentives such as a grant or no-interest loan, under federal "anti-double-dipping" rules (Ing, 1997).

The PTC, a key incentive, helps level the economic playing field for wind projects in energy markets where other forms of energy are also subsidized. It must be noted, however, that the current "on-again, off-again" status of the credit is hobbling project development and the industry as a whole. Uncertainty also affects relationships with vendors and substantially increases costs as orders are rushed to meet PTC deadlines or as planning grinds to a halt and income is lost while the industry awaits an extension. One major U.S. developer stated that a 5 year extension of the PTC would provide enough long-term certainty to squeeze an additional $25 \%$ out of vendor costs. The wind energy industry is currently seeking a longterm extension of the credit.

Stricter environmental regulations enhance wind energy's competitiveness. Wind power's environmental impact per unit of electricity generated is much lower than that of mainstream forms of electricity generation, as wind energy neither emits pollutants, wastes, or greenhouse gases, nor damages the environment through resource extraction. The higher the air quality and other environmental standards 
adopted in a country, the more competitive wind energy therefore becomes in the marketplace. Conversely, a relaxation of standards or failure to internalize environmental costs through pollution charges or other processes makes polluting forms of electricity generation appear deceptively cheap. The cost of producing electricity from coal or oil would double and the cost of electricity production from gas would increase by $30 \%$ if some external costs such as damage to the environment (not including that of global warming) and to health were taken into account, according to a study by the European Union (more information available at http://europa.eu.int/comm/research/press/2001/pr2007en.html). Similarly, in the United States, state attempts to set up a process by which some of the environmental costs of electricity production, or externalities, could be taken into account in economic calculations have focused on air emissions and set externalities estimates in the range of 3 to 6 cents $/ \mathrm{kWhr}$ for coal and 0.5 to 2 cents/kWhr for natural gas. For a comprehensive study, see Ottinger et al. (1990). This is an important economic issue, because the hidden "subsidy" that governments and markets give to polluting energy sources by partially or fully ignoring their health and environmental costs is typically much larger than direct subsidies to such energy sources.

The capital cost of wind from 2000 to 2020 is shown in Fig. 3.4. Wind energy provides the following ancillary economic benefits.

- Less dependence on fossil fuels, which can be subject to rapid price fluctuations and supply problems. By the end of 2006, the American Wind Energy Association (AWEA) estimates wind energy use will save over 0.5 billion cubic feet (Bcf) of natural gas each day, relieving some of the current supply shortages.

- Steady income for farmers or ranchers who own the land on which wind farms are built, and for the communities in which they live. In Texas, for example, ranchers have been reaping income from the wind even as their royalties from oil wells have declined.

- An increase in the property tax base for rural counties

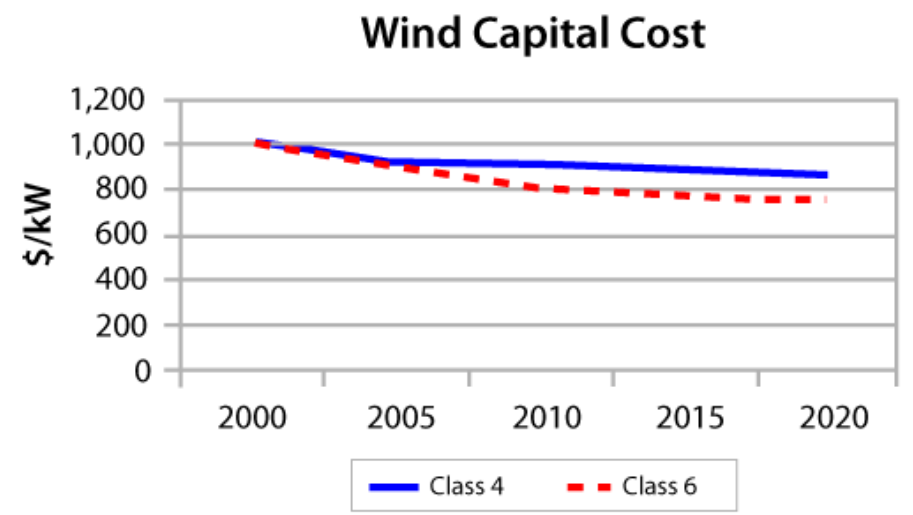

Fig. 3.4. Wind capital cost. 


\section{Wind Cost of Energy}

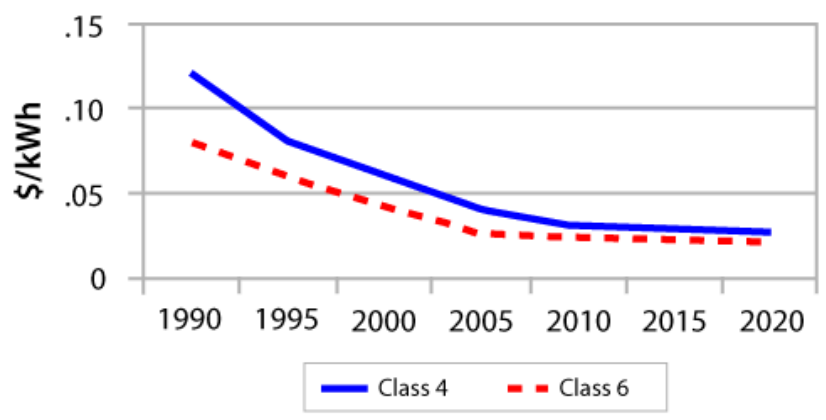

Fig. 3.5. Wind cost of energy.

The cost of wind-generated electricity has dropped dramatically since 1980, when the first commercial wind plants began operating in California (Fig. 3.5). Since 2003, however, wind energy prices have increased. Figure 3.6 shows that in 2006 the price paid for electricity generated in large wind farms was between 3.0 and 6.5 cents $/ \mathrm{kWhr}$ with an average near 5 cents $/ \mathrm{kWhr}(1 \mathrm{cent} / \mathrm{kWhr}=$ \$10/MWhr) (Wiser and Bolinger, 2007). This price includes the benefit of the federal PTC, state incentives, and revenue from the sale of any renewable energy credits.

Wind energy prices have increased since 2002 for the following reasons (Wiser and Bolinger, 2007).

- Shortages of turbines and components resulting from the dramatic recent growth of the wind industry in the United States and Europe

- The weakening U.S. dollar relative to the euro (many major turbine components are imported from Europe, and there are relatively few wind turbine component manufacturers in the United States)

- A significant rise in material costs such as steel and copper as well as transportation fuels over the last 3 years

- The on-again, off-again cycle of the wind energy PTC (uncertainty hinders investment in new turbine production facilities and encourages hurried and expensive production, transportation, and installation of projects when the tax credit is available)

Expected future reductions in wind energy costs would come partly from expected investment in the expansion of manufacturing volume in the wind industry. In addition, a stable U.S. policy for renewable energy and a heightened research, development, and demonstration (RD\&D) effort could also lower costs.

The current installed capital cost of offshore projects is estimated to be in the range of $\$ 2,400$ to $\$ 5000 / \mathrm{kWhr}$ (Black \& Veatch, 2007; Pace Global, 2007). Because offshore wind energy tends to take advantage of extensive land-based experience and mature offshore oil and gas practices, offshore cost reductions are not expected to be as great as land-based reductions spanning the past two decades. However, offshore wind technology is considerably less mature than land-based wind energy, so it does have significant potential for future cost reduction. These cost reductions are achievable through technology development and innovation, implementation and customization of offshore oil and gas practices, and learning-curve reductions that take advantage of more efficient manufacturing and deployment processes and procedures.

Operating and maintenance (O\&M) costs have also dropped significantly since the 1980 s as a result of improved designs and increased quality. O\&M data from the technology installed well before 2000 show relatively high annual costs that increase with the age of the equipment. Annual O\&M costs are reported to be as high as $\$ 30-\$ 50 / \mathrm{MWhr}$ for wind power plants with 1980 s technology, whereas the latest generation of turbines has reported annual O\&M costs below \$10/MWhr (Wiser and Bolinger, 2007). 


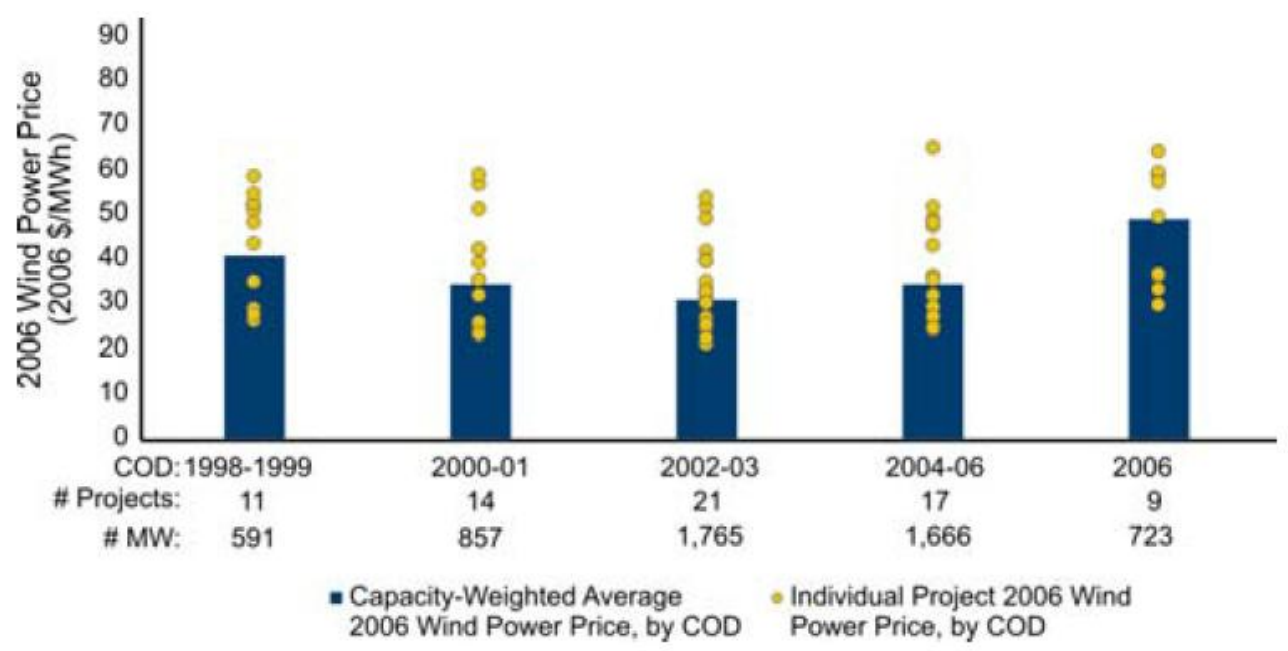

Fig. 3.6. Wind energy price by commercial operation date (COD) using 2006 data.

Figure 3.7 shows annual O\&M expenses by wind project age and equipment installation year. Relative to wind power prices shown in Fig. 3.6, the O\&M costs can be a significant portion of the price paid for wind-generated electricity. Since the late $1990 \mathrm{~s}$, modern equipment operation costs have been reduced for the initial operating years. Whether annual operation costs grow as these modern turbines age is yet to be determined and will depend greatly on the quality of these new machines.

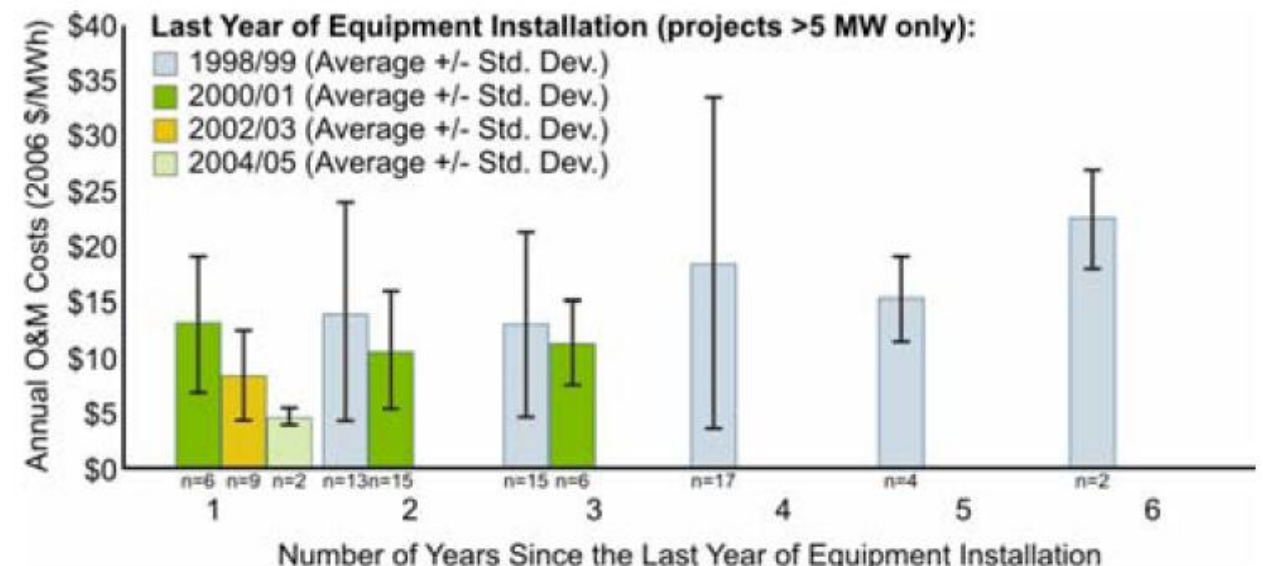

Fig. 3.7. Operation and maintenance costs for large-scale wind plants installed within the last 10 years for the early years of operation. Source: Wiser and Bolinger (2007).

SCADA systems are being used to monitor very large wind farms and dispatch maintenance personnel rapidly and efficiently. This is one area where experience in managing large numbers of very large machines has paid off. Availability, defined as the fraction of time during which the equipment is ready to operate, is now more than $95 \%$ and is often reported to exceed $98 \%$. These data indicate the potential for improving reliability and reducing maintenance costs (Walford, 2006).

Distributed wind technology (DWT) applications refer to turbine installations on the customer side of the utility meter. These machines range in size from less than $1 \mathrm{~kW}$ to multimegawatt, utility-scale machines used to offset electricity consumption at the retail rate.

Reliability and acoustic emissions are the prominent issues for small DWT applications. These installations usually consist of single machines that are widely scattered, requiring simplicity in design, 
ease of repair, and long maintenance and inspection intervals. Because DWT applications are usually close to workplaces or residences, limiting sound emissions is critical for market acceptance and zoning approvals. DWT applications are also usually located in areas with low wind speeds that are unsuitable for utility-scale applications, so DWT places a premium on low-wind-speed technologies.

The cost of DWT turbines per kilowatt scales inversely with turbine size. Small-scale DWT installation costs are always higher than those for utility-scale installations because the construction effort cannot be amortized over a large number of machines. For a $1 \mathrm{~kW}$ system, hardware costs alone can be as high as $\$ 5,000$ to $\$ 7,000 / \mathrm{kW}$. Installation costs vary widely because of site-specific factors such as zoning and/or permitting costs, interconnection fees, balance-of-station costs, shipping, and the extent of do-it-yourself participation. Five-year warranties are now the industry standard for small wind turbines, although it is not yet known how this contributes to turbine cost. The higher costs of this technology are partially offset by the ability of these applications to compete with retail electricity rates. In addition, the use of small turbines makes connection to the electric distribution system possible, eliminating the need for an expensive interconnection between the substation and the transmission.

Tower and foundation costs make up a larger portion of DWT installed cost, especially for wind turbines of less than $20 \mathrm{~kW}$. Unlike utility-scale turbines that commonly use tapered tubular steel towers, multiple types, sources, and heights of towers are available for small wind turbines.

\subsection{WIND ENVIRONMENTAL IMPACTS}

It is hard to imagine an energy source more benign to the environment than wind power; it produces no air or water pollution, involves no toxic or hazardous substances (other than those commonly found in large machines), and poses no threat to public safety. Wind energy development environmental concerns include, noise, visual impacts, and avian and bat mortality. Although wind power plants have relatively little impact on the environment compared to fossil fuel power plants, concerns have been raised over the noise produced by the rotor blades, visual impacts, and deaths of birds and bats that fly into the rotors (avian/bat mortality).

- Noise-Like all mechanical systems, wind turbines produce some noise when they operate. Most of the turbine noise is masked by the sound of the wind itself, and the turbines run only when the wind blows. In recent years, engineers have made design changes to reduce the noise from wind turbines. Early model turbines are generally noisier than most new and larger models. As wind turbines have become more efficient, more of the wind is converted into rotational torque and less into acoustic noise. Additionally, proper siting and insulating materials can be used to minimize noise impacts.

- Visual Impacts - Because they must generally be sited in exposed places, wind turbines are often highly visible; however, being visible is not necessarily the same as being intrusive. Aesthetic issues are by their nature highly subjective. Proper siting decisions can help to avoid any aesthetic impacts to the landscape. One strategy being used to partially offset visual impacts is to site fewer turbines in any one location by using multiple locations and by using today's larger and more efficient models of wind turbines.

- Avian/Bat Mortality - Bird and bat deaths are one of the most controversial biological issues related to wind turbines. The deaths of birds and bats at wind farm sites have raised concerns by fish and wildlife agencies and conservation groups. On the other hand, several large wind facilities have operated for years with only minor impacts on these animals.

To try to address this issue, the wind industry and government agencies have sponsored research into collisions, relevant bird and bat behavior, mitigation measures, and appropriate study design protocols. In addition, project developers are required to collect data through monitoring efforts at existing and proposed wind energy sites. Careful site selection is needed to minimize fatalities, and in some cases additional research may be needed to address bird and bat impact issues. 
While structures such as smokestacks, lighthouses, tall buildings, and radio and television towers have also been associated with bird and bat kills, bird and bat mortality is a serious concern for the wind industry.

In California, bird deaths from electrocution or collisions with spinning rotors have emerged as a problem at the Altamont Pass wind "farm," where more than 30 threatened golden eagles and 75 other raptors such as red-tailed hawks died or were injured during a 3 year period. Studies under way to determine the cause of these deaths and find preventive measures may have an important impact on the public image and rate of growth of the wind industry. In appropriate areas, and with imagination, careful planning, and early contacts between the wind industry, environmental groups, and affected communities, siting and environmental problems should not be insurmountable.

- Use of land - Most studies assume that wind turbines will be spaced a certain distance apart and that all of the land in between should be regarded as occupied. This leads to some quite disturbing estimates of the land area required to produce substantial quantities of wind power. According to one widely circulated report from the 1970 s, generating $20 \%$ of U.S. electricity from windy areas in 1975 would have required siting turbines on 18,000 square miles, or an area about $7 \%$ the size of Texas.

In reality, however, the wind turbines themselves occupy only a small fraction of this land area, and the rest can be used for other purposes or left in its natural state. For this reason, wind power development is ideally suited to farming areas. In Europe, farmers plant right up to the base of turbine towers, while in California, cows can be seen peacefully grazing in their shadow. The leasing of land for wind turbines, far from interfering with farm operations, can bring substantial benefits to landowners in the form of increased income and land values. Perhaps the greatest potential for wind power development is consequently in the Great Plains, where wind is plentiful and vast stretches of farmland could support hundreds of thousands of wind turbines.

In other settings, however, wind power development can create serious land-use conflicts. In forested areas it may mean clearing trees and cutting roads, a prospect that is sure to generate controversy, except possibly in areas where heavy logging has already occurred. And near populated areas, wind projects often run into stiff opposition from people who regard them as unsightly and noisy, or who fear their presence may reduce property values.

- Global Warming - Wind energy can help fight global warming. Wind turbines produce no air emissions or greenhouse gases.

- Lightning - Ongoing research and increased operator experience are improving the understanding of lightning and wind turbines.

- TV/Radio/Radar Interference - In the past, older turbines with metal blades caused television interference in areas near the turbine. Interference from modern turbines is unlikely because many components formerly made of metal are now made from composites. There is still an issue with radar interference, but research in materials, equipment, placement, and radar technology are mitigating that concern. This is of most concern near military bases and airports because of interference with air traffic control radar, but wind turbines can also interfere with weather radar. Developers must work with the Federal Aviation Authority and other authorities when licensing a site so that these issues are addressed.

- Other Concerns - Unlike most other generation technologies, wind turbines do not use combustion to generate electricity, and hence do not produce air emissions. The only potentially toxic or hazardous materials are relatively small amounts of lubricating oils and hydraulic and insulating fluids. Therefore, contamination of surface water, groundwater, or soils is highly unlikely. The primary health and safety considerations are related to blade movement and the presence of industrial equipment in areas potentially accessible to the public. And like all electrical generating facilities, wind generators produce electric and magnetic fields. 


\subsection{CONCLUSIONS}

Wind costs and environmental impacts are both low, and wind technology has reached a rather mature status. The main issues associated with wind are with regard to grid reliability or stability at penetrations of $20 \%$ or higher. As previously discussed, this issue does not seem to be present in the Southeast.

As shown in Table 3.1, the onshore potential for wind generation in the Southeast is clearly limited without transmission access to the wind resources from the extended southeastern states (Missouri, Oklahoma, and Texas). This is primarily because only $0.23 \%$ of the land area is available for wind generation after exclusions. Even without exclusions only a little over $1 \%$ of land area is viable.

On the other hand, offshore wind resources as shown in Table 3.5, clearly establish the need for offshore wind in any Southeast renewable portfolio. By 2030, offshore wind alone using only ac cables could supply a nominal $100 \mathrm{GW}$ of capacity producing $350 \mathrm{TWhr}$ annually or $27.5 \%$ of 2009 generation in the southeastern states. Assuming that only $34 \%$ of the area beyond $3 \mathrm{~nm}$ is developed, the resource could ultimately provide $264 \mathrm{GW}$ of capacity and $923 \mathrm{TWhr}$ of energy annually.

Wind is essentially required for most renewable scenarios. To utilize wind, the Southeast must get significant wind resources, either from offshore wind or through sufficient transmission capacity, to link wind resources in Missouri, Oklahoma, or Texas. If this is accomplished, achieving $20 \%$ renewable generation in the Southeast will be possible.

\subsection{REFERENCES}

Balck \& Veatch Corporation. 2007. 20 Percent Wind Energy Penetration in the United States: A Technical Analysis of the Energy Resource, B\&V Project Number 144864, www.bv.com, October.

EERE. 2011. http://www.windpoweringamerica.gov/win_maps.asp

EERE. 2009. 2009 Wind Technologies Market Report, August 2010, http://www1.eere.energy.gov/windandhydro/pdfs/2009_wind_technologies_market_report.pdf

Germain, A., Bain, D. 1997. "Economics of Wind Farm Layout," Windpower 1997 proceedings, American Wind Energy Association, Washington, D.C.

Ing, E. 1997. “Anti-Double Dipping Rules for Federal Tax Incentives,” Windpower 1997 proceedings, American Wind Energy Association, Washington, D.C.

Ottinger et al. 1990. "Environmental Costs of Electricity," Pace University Center for Environmental Legal Studies, Oceana Publications.

Pace Global Energy Services. 2007. Assessment of Offshore Wind Power Resources, prepared for the Long Island Power Authority, www.paceglobal.com

Walford, C. Wind Turbine Reliability: Understanding and Minimizing Win Turbine Operation and Maintenance Costs, SAND2006-110, Sandia National Laboratories, March 2006.

Wiser, R. and Bolinger, M. 2007. Lawrence Berkeley National Laboratory. Annual Report on U.S. Wind Power Installation, Cost, and Performance Trends: 2006, May 2007. These reports are issued annually. http://www.in.gov/oed/files/DOE_Wind_Growth_May_2007_41435.pdf

Wiser, R., Kahn, E. 1996. Alternative Windpower Ownership Structures: Financing Terms and Project Costs," Lawrence Berkeley Laboratory, Energy and Environment Division.

\subsection{ADDITIONAL RESOURCES}

2008 Wind Technologies Market Report, http://www.windpoweringamerica.gov/filter_detail.asp?itemid=2306report

Wind Powering America, http://www.windpoweringamerica.gov/

National Renewable Energy Laboratory, 2010, Maps of wind resources 
Wind Resource Potential: Cumulative Rated Capacity vs. Gross Capacity Factor (CF) by state, $\mathrm{http} / /$ www.windpoweringamerica.gov/images/windmaps/xx_wind_potential_chart.jpg where $\mathrm{xx}$ is the state abbreviation; e.g., al, tn, tx etc.

Factsheets by states providing economic development information,

http://www.windpoweringamerica.gov/pdfs/economic_development/2008/ $\mathrm{xx}$ wind benefits factsheet.pdf where $\mathrm{xx}$ is the state abbreviation.

Cost of Wind Power, http://www1.eere.energy.gov/tribalenergy/guide/costs_wind_turbines.html

Wind Web Tutorial, http://www.awea.org/faq/wwt_costs.html

The Economics of Wind Energy, American Wind Energy Association, http://www.awea.org/pubs/factsheets/EconomicsOfWind-Feb2005.pdf

Flowers, Larry. Wind Energy Update, National Renewable Energy Laboratory, June 2010 http://www.windpoweringamerica.gov/pdfs/wpa/wpa_update.pdf

20\% Wind Energy by 2030 - Increasing Wind's Contribution to U.S. Electricity Supply, DOE/GO102008-2567, July 2008, Available at http://www1.eere.energy.gov/windandhydro/pdfs/41869.pdf

Wind Energy Development Environmental Concerns, Wind Energy Development Programmatic EIS Information Center, http://windeis.anl.gov/guide/concern/index.cfm

"Wind Energy, Environmental Impact," Encyclopedia of Alternate Energy and Sustainable Living, http://www.daviddarling.info/encyclopedia/W/AE_wind_energy_environmental_impact.html

Environmental Impacts of Renewable Energy Technologies, Union of Concerned Scientists, briefing paper adapted from material in the UCS book Cool Energy: Renewable Solutions to Environmental Problems, by Michael Brower (MIT Press, 1992), 220 pp. http://www.ucsusa.org/clean_energy/ technology_and_impacts/impacts/environmental-impacts-of.html 


\section{SOLAR ENERGY}

Because more energy from the sun falls on the earth in $1 \mathrm{hr}$ than is used by everyone in the world in 1 year, solar (the Latin word for sun) is a powerful source of energy that can be used to heat, cool, and light our homes and businesses. A variety of technologies convert sunlight to usable energy for buildings. The most commonly used solar technologies for homes and businesses are solar water heating, passive solar design for space heating and cooling, and solar photovoltaics for electricity.

Businesses and industry also use these technologies to diversify their energy sources, improve efficiency, and save money. To produce electricity on a massive scale to power cities and small towns, developers and utilities are also using solar photovoltaic and concentrating solar power technologies.

This report will focus on the production of electricity from solar, concentrating on solar collectors, photovoltaic technology, etc. Nonelectrical applications, such as passive solar, water heating, and space heating and cooling, are described only briefly. While the latter do impact electricity use in a generally positive manner, they are more in keeping with conservation than direct utilization of renewable technology to generate electricity.

\subsection{NONELECTRICAL APPLICATIONS OF SOLAR TECHNOLOGY}

\subsubsection{Passive Solar Technology}

These technologies harness heat from the sun to warm our homes and businesses in winter. Today, many buildings are designed to take advantage of this natural resource through the use of passive solar heating and lighting.

The south side of a building always receives the most sunlight. Therefore, buildings designed for passive solar heating usually have large, south-facing windows. Materials that absorb and store the sun's heat can be built into the sunlit floors and walls. The floors and walls will then heat up during the day and slowly release heat at night, when the heat is needed most. This passive solar design feature is called direct gain.

Of course, too much solar heating and lighting can be a problem during the hot summer months. Fortunately, there are many design features that help keep passive solar buildings cool in the summer. For instance, overhangs can be designed to shade windows when the sun is high in the summer. Sunspaces can be closed off from the rest of the building. And a building can be designed to use fresh-air ventilation in the summer.

\subsubsection{Solar Water Heating}

These technologies harness heat from the sun to provide hot water for homes and businesses. The sun can be used to heat water used in buildings and swimming pools.

Most solar water heating systems for buildings have two main parts: a solar collector and a storage tank. The most common collector is called a flat-plate collector. Mounted on the roof, it consists of a thin, flat, rectangular box with a transparent cover that faces the sun. Small tubes run through the box and carry the fluid - either water or other fluid, such as an antifreeze solution - to be heated. The tubes are attached to an absorber plate, which is painted black to absorb the heat. As heat builds up in the collector, it heats the fluid passing through the tubes.

The storage tank then holds the hot liquid. It can be just a modified water heater, but it is usually larger and very well insulated. Systems that use fluids other than water usually heat the water by passing it through a coil of tubing in the tank, which is full of hot fluid.

Solar water heating systems can be either active or passive, but the most common are active systems. Active systems rely on pumps to move the liquid between the collector and the storage tank, while passive systems rely on gravity and the tendency for water to naturally circulate as it is heated. 
Swimming pool systems are simpler. The pool's filter pump is used to pump the water through a solar collector, which is usually made of black plastic or rubber. And of course, the pool stores the hot water.

\subsubsection{Solar Process Heat}

These technologies use solar energy to heat or cool commercial and industrial buildings. Commercial and industrial buildings may use the same solar technologies - photovoltaics, passive heating, daylighting, and water heating - that are used for residential buildings. These nonresidential buildings can also use solar energy technologies that would be impractical for a home. These technologies include ventilation air preheating, solar process heating, and solar cooling.

\subsubsection{Space Heating}

Many large buildings need ventilated air to maintain indoor air quality. In cold climates, heating this air can use large amounts of energy, but a solar ventilation system can preheat the air, saving both energy and money. This type of system typically uses a transpired collector, which consists of a thin, black metal panel mounted on a south-facing wall to absorb the sun's heat. Air passes through the many small holes in the panel. A space behind the perforated wall allows the air streams from the holes to mix together. The heated air is then sucked out from the top of the space into the ventilation system.

\subsubsection{Process Water Heating}

Solar water-heating systems are designed to provide large quantities of hot water for nonresidential buildings. A typical system includes solar collectors that work along with a pump, heat exchanger, and/or one or more large storage tanks. The two main types of solar collectors used for nonresidential buildings - an evacuated-tube collector and a linear concentrator - can operate at high temperatures with high efficiency. An evacuated-tube collector is a set of many double-walled glass tubes and reflectors to heat the fluid inside the tubes. A vacuum between the two walls insulates the inner tube, retaining the heat. Linear concentrators use long, rectangular, curved (U-shaped) mirrors tilted to focus sunlight on tubes that run along the length of the mirrors. The concentrated sunlight heats the fluid within the tubes.

\subsubsection{Space Cooling}

Space cooling can be accomplished using thermally activated cooling systems (TACS) driven by solar energy. Because of a high initial cost, the use of TACS is not widespread. The two systems currently in operation are solar absorption systems and solar desiccant systems. Solar absorption systems use thermal energy to evaporate a refrigerant fluid to cool the air. In contrast, solar desiccant systems use thermal energy to regenerate desiccants that dry the air, thereby cooling the air. These systems also work well with evaporative coolers (also called "swamp coolers") in more humid climates.

\subsection{ELECTRICITY-GENERATING APPLICATIONS OF SOLAR ENERGY}

\subsubsection{Concentrating Solar Collectors}

These technologies harness heat from the sun to provide electricity for large power stations. The three main types of concentrating solar power systems are linear concentrator, dish/engine, and power tower systems.

Linear concentrator systems collect the sun's energy using long rectangular, curved (U-shaped) mirrors. The mirrors are tilted toward the sun, focusing sunlight on tubes (or receivers) that run the length of the mirrors. The reflected sunlight heats a fluid flowing through the tubes. The hot fluid then is used to boil water in a conventional steam-turbine generator to produce electricity. There are two major types of 
linear concentrator systems: parabolic trough systems, where receiver tubes are positioned along the focal line of each parabolic mirror, and linear Fresnel reflector systems, where one receiver tube is positioned above several mirrors to allow the mirrors greater mobility in tracking the sun.

A dish/engine system uses a mirrored dish similar to a very large satellite dish. The dish-shaped surface directs and concentrates sunlight onto a thermal receiver, which absorbs and collects the heat and transfers it to the engine generator. The most common type of heat engine used today in dish/engine systems is the Stirling engine. This system uses the fluid heated by the receiver to move pistons and create mechanical power. The mechanical power is then used to run a generator or alternator to produce electricity.

A power tower system uses a large field of flat, sun-tracking mirrors known as heliostats to focus and concentrate sunlight onto a receiver on the top of a tower. A heat-transfer fluid heated in the receiver is used to generate steam, which, in turn, is used in a conventional turbine generator to produce electricity. Some power towers use water/steam as the heat-transfer fluid. Other advanced designs are experimenting with molten nitrate salt because of its superior heat-transfer and energy-storage capabilities.

The energy-storage capability, or thermal storage, allows the system to continue to dispatch electricity during cloudy weather or at night.

\subsubsection{Solar Photovoltaic Technology}

These technologies convert sunlight directly into electricity to power homes and businesses. Solar cells, also called photovoltaic (PV) cells by scientists, convert sunlight directly into electricity. PV gets its name from the process of converting light (photons) to electricity (voltage), which is called the PV effect. The PV effect was discovered in 1954, when scientists at Bell Telephone discovered that silicon (an element found in sand) created an electric charge when exposed to sunlight. Soon solar cells were being used to power space satellites and smaller items like calculators and watches. Today, thousands of people power their homes and businesses with individual solar PV systems. Utility companies are also using PV technology for large power stations.

Solar panels used to power homes and businesses are typically made from solar cells combined into modules that hold about 40 cells. A typical home will use about 10 to 20 solar panels to power the home. The panels are mounted at a fixed angle facing south, or they can be mounted on a tracking device that follows the sun, allowing them to capture the most sunlight. A tracking system may be a single adjustment to the south facing azimuth or latitude angle or a multiple axis system. In general, it has not proven cost-effective to use multiple axis systems. A solar array is formed when many solar panels are combined together to create a single system. For large electric utility or industrial applications, hundreds of solar arrays are interconnected to form a large utility-scale PV system.

Traditional solar cells are made from silicon, are usually flat plate, and generally are the most efficient. Second-generation solar cells are called thin-film solar cells because they are made from amorphous silicon or non-silicon materials such as cadmium telluride. Thin-film solar cells use layers of semiconductor materials only a few micrometers thick. Because of their flexibility, thin-film solar cells can double as rooftop shingles and tiles, building facades, or the glazing for skylights.

Third-generation solar cells are being made from variety of new materials besides silicon, including solar inks using conventional printing press technologies, solar dyes, and conductive plastics. Some new solar cells use plastic lenses or mirrors to concentrate sunlight onto a very small piece of high-efficiency PV material. The PV material is more expensive, but because so little is needed, these systems are becoming cost-effective for use by utilities and industry. However, because the lenses must be pointed at the sun, the use of concentrating collectors is limited to the sunniest parts of the country.

\subsection{SOLAR ENERGY RESOURCE IN SOUTHEAST}

Solar maps provide monthly average daily total solar resource information on grid cells. The insolation values represent the resource available to a flat-plate collector, such as a photovoltaic panel, 
oriented due south at an angle from horizontal to equal to the latitude of the collector location. This is typical practice for PV system installation, although other orientations are also used.

The national solar PV resource potential map in Fig. 4.1 shows that in the Southeast, most of the states have a solar radiation level of around $5 \mathrm{kWhr} / \mathrm{m}^{2} /$ day, except for Tennessee, Kentucky, and West Virginia, which are closer to $4 \mathrm{kWhr} / \mathrm{m}^{2} /$ day.

Figure 4.2 shows the national concentrating solar power (CSP) resource potential map. Most of the southeastern states have a concentrating solar level of around $4 \mathrm{kWhr} / \mathrm{m}^{2} /$ day, except for most of West Virginia and part of Kentucky and Tennessee, which are essentially at a level $3 \mathrm{kWhr} / \mathrm{m}^{2} /$ day.

The U.S. solar radiation resource maps display the general trends in the amount of solar radiation received in the United States and its territories (http://rredc.nrel.gov/solar/pubs/redbook/\#maps).

Presented are spatial interpolations of solar radiation values derived from the 1961-1990 National Solar Radiation Data Base (NSRDB) and published in the Solar Radiation Data Manual for Flat-Plate and Concentrating Collectors. The data from which these maps were generated can be found one directory down at Redbook2.

Maps of minimum, maximum, and average solar radiation data are available. Averaging all 30 years of data for each site produces maps of average values. Maps of minimum and maximum values are composites of specific months and years for which each site achieved its minimum or maximum amounts of solar radiation.

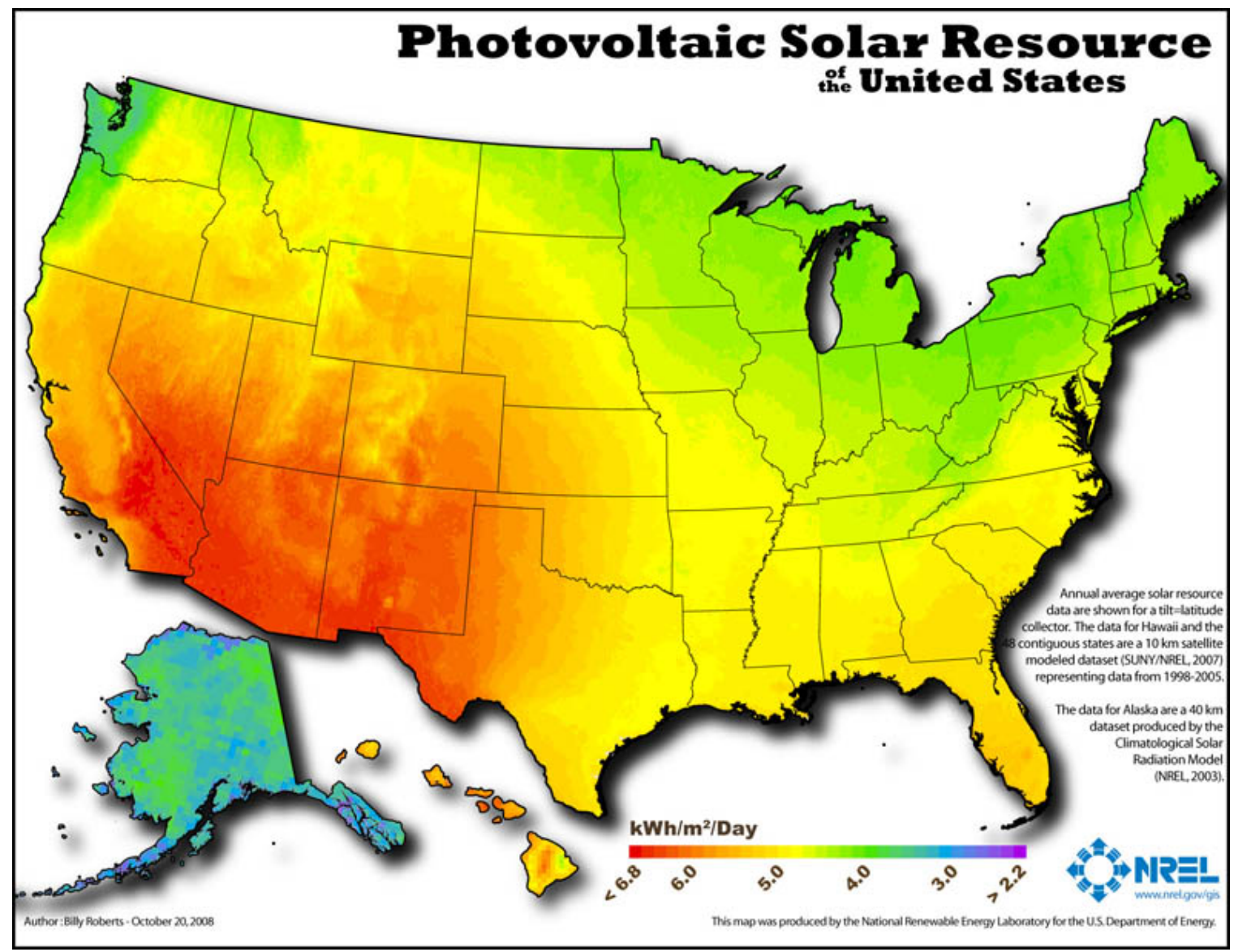

Fig. 4.1. National solar photovoltaics resource potential map of United States. 


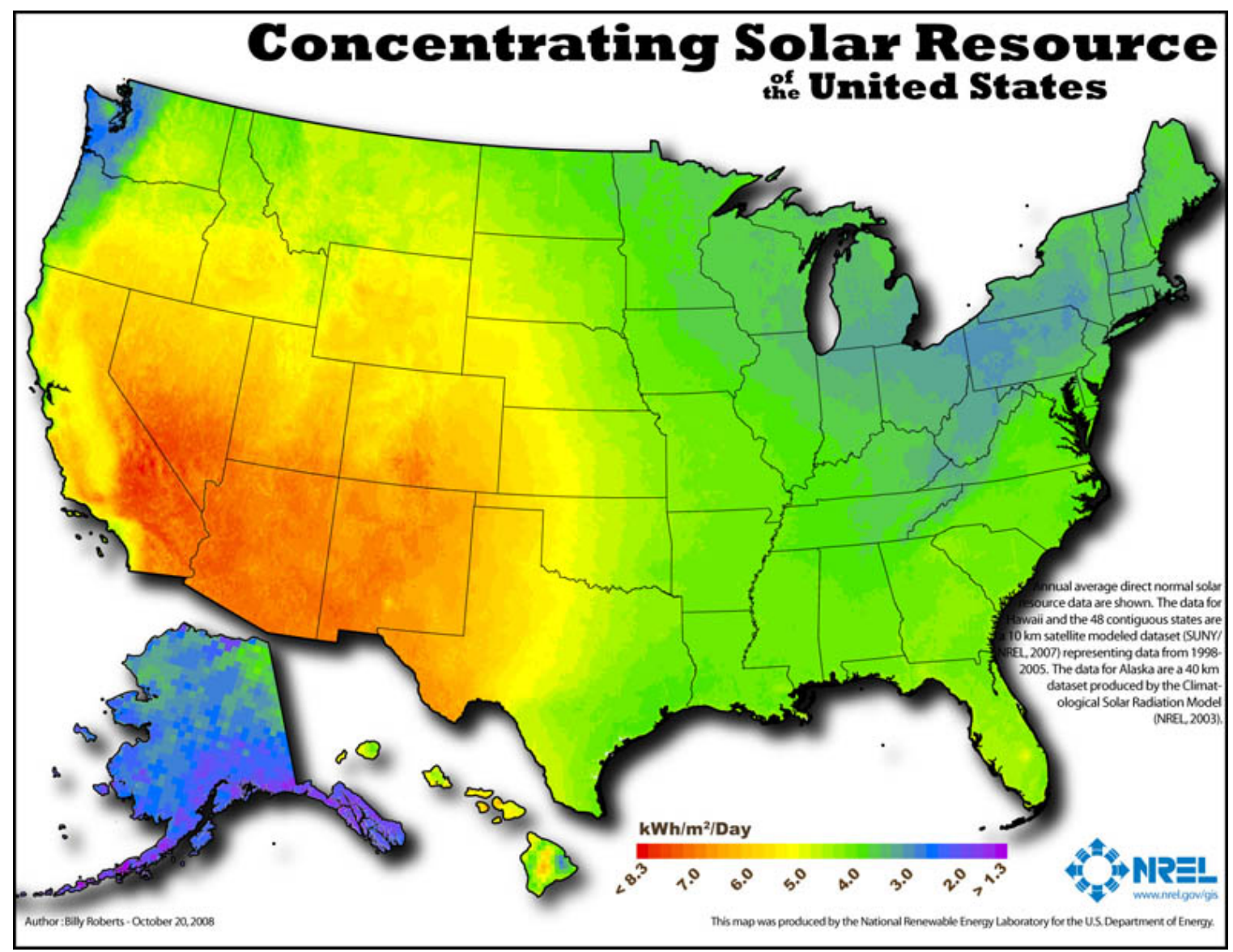

Fig. 4.2. National concentrating solar resource map of United States.

Maps of the 30 year averages for a particular month and the overall 30 year average solar radiation atlas for all months are available. Data from the following 14 different collector orientations were used to make the solar atlas.

1. Single-Axis Tracking Concentrator, East-West Axis

2. North-South Axis Tracking Concentrator Tilted at Latitude

3. North-South Axis Tracking Concentrator

4. Two-Axis Tracking Concentrator

5. Two-Axis Tracking Flat Plate

6. Flat Plate Tilted South at Latitude

7. Flat Plate Tilted South at Latitude -15 Degrees

8. Flat Plate Tilted South at Latitude +15 Degrees

9. Horizontal Flat Plate

10. South-Facing Vertical Flat Plate

11. North-South Axis Tracking Flat Plate

12. North-South Axis Tracking Flat Plate Tilted at Latitude

13. North-South Axis Tracking Flat Plate Tilted at Latitude - 15 Degrees

14. North-South Axis Tracking Flat Plate Tilted at Latitude + 15 Degrees

Table 4.1 shows the annual average solar radiation resource data of Southeast states with different collector orientations. 
Table 4.1. Annual average solar radiation resource map of southeastern states with different collector orientations $\left(\mathrm{kWhr} / \mathrm{m}^{2} / \mathrm{day}\right)$

\begin{tabular}{|c|c|c|c|c|c|c|c|c|c|c|c|c|}
\hline $\begin{array}{c}\text { Collector } \\
\text { orientation } \\
\text { ID }\end{array}$ & $\mathbf{A L}$ & $\mathbf{A R}$ & FL & GA & KY & LA & MI & NC & SC & $\mathbf{T N}$ & VA & WV \\
\hline 1 & 3 to 4 & 3 to 4 & 3 to 4 & 3 to 4 & 2 to 3 & 3 to 4 & 3 to 4 & 3 to 4 & 3 to 4 & 2 to 3 & 2 to 3 & 2 to 3 \\
\hline 2 & 3 to 4 & 4 to 5 & 4 to 5 & 3 to 5 & 3 to 4 & 3 to 4 & 3 to 4 & 3 to 4 & 4 to 5 & 3 to 4 & 3 to 4 & 3 to 4 \\
\hline 3 & 3 to 4 & 3 to 4 & 3 to 4 & 3 to 4 & 3 to 4 & 3 to 4 & 3 to 4 & 3 to 4 & 3 to 4 & 3 to 4 & 3 to 4 & 2 to 3 \\
\hline 4 & 3 to 5 & 4 to 5 & 4 to 5 & 4 to 5 & 3 to 4 & 3 to 5 & 3 to 5 & 4 to 5 & 4 to 5 & 3 to 4 & 3 to 4 & 3 to 4 \\
\hline 5 & 6 to 7 & 6 to 7 & 6 to 7 & 6 to 7 & 5 to 7 & 6 to 7 & 6 to 7 & 6 to 7 & 6 to 7 & 6 to 7 & 6 to 7 & 5 to 6 \\
\hline 6 & 4 to 5 & 4 to 6 & 5 to 6 & 5 to 6 & 4 to 5 & 4 to 5 & 4 to 5 & 4 to 5 & 5 to 6 & 4 to 5 & 4 to 5 & 4 to 5 \\
\hline 7 & 4 to 5 & 4 to 5 & 5 to 6 & 4 to 5 & 4 to 5 & 4 to 5 & 4 to 5 & 4 to 5 & 4 to 5 & 4 to 5 & 4 to 5 & 4 to 5 \\
\hline 8 & 4 to 5 & 4 to 5 & 4 to 6 & 4 to 5 & 4 to 5 & 4 to 5 & 4 to 5 & 4 to 5 & 4 to 5 & 4 to 5 & 4 to 5 & 4 to 5 \\
\hline 9 & 4 to 5 & 4 to 5 & 4 to 5 & 4 to 5 & 4 to 5 & 4 to 5 & 4 to 5 & 4 to 5 & 4 to 5 & 4 to 5 & 4 to 5 & 3 to 4 \\
\hline 10 & 2 to 4 & 3 to 4 & 2 to 4 & 3 to 4 & 2 to 3 & 2 to 3 & 2 to 4 & 3 to 4 & 3 to 4 & 2 to 4 & 3 to 4 & 2 to 3 \\
\hline 11 & 5 to 6 & 5 to 6 & 6 to 7 & 5 to 6 & 5 to 6 & 5 to 6 & 5 to 6 & 5 to 6 & 5 to 6 & 5 to 6 & 5 to 6 & 4 to 6 \\
\hline 12 & 6 to 7 & 6 to 7 & 6 to 7 & 6 to 7 & 5 to 6 & 6 to 7 & 6 to 7 & 6 to 7 & 6 to 7 & 5 to 7 & 5 to 6 & 5 to 6 \\
\hline 13 & 6 to 7 & 6 to 7 & 6 to 7 & 6 to 7 & 5 to 6 & 6 to 7 & 6 to 7 & 6 to 7 & 6 to 7 & 5 to 7 & 5 to 6 & 5 to 6 \\
\hline 14 & 5 to 7 & 6 to 7 & 6 to 7 & 6 to 7 & 5 to 6 & 5 to 7 & 6 to 7 & 6 to 7 & 6 to 7 & 5 to 6 & 5 to 6 & 5 to 6 \\
\hline
\end{tabular}

In general this data supports the conclusion that a PV array in the Southeast will require 20-25\% more collector area to provide the same energy output as a plant in the Southwest or California. For concentrating solar collectors, the Southeast plant would require 50-75\% larger collection area. In addition, fluctuation in output temperatures and steam quality caused by cloud cover present additional design constraints. In general, this will require that the cost per kilowatt-hour be correspondingly higher for a system of the same capacity. The primary reasons for this reduced capacity are greater cloud cover and other less favorable atmospheric conditions, which effectively reduce the capacity factor (Average/Peak) from a nominal $20 \%$ for a Southwest plant to a $12-16 \%$ for a Southeast plant.

\subsection{SOLAR INSTALLATION IN SOUTHEAST}

The PV installation in each state to date is shown in Table 4.2.

Florida Power and Light (FPL) is constructing at least three solar energy projects, at diverse locations throughout the state. Over the life of the centers, the solar energy produced will prevent the emission of more than 3.5 million tons of greenhouse gases, which according to the U.S. Environmental Protection Agency is equivalent to removing 25,000 cars from our roads, annually. Construction of these three nextgeneration solar energy centers will result in Florida becoming the second largest supplier of utility-scale solar power in the nation.

At $25 \mathrm{MW}(\mathrm{ac})$, the DeSoto Next-Generation Solar Energy Center consists of more than 90,500 solar panels and is the largest solar photovoltaic plant in the country. Annual estimated generation is about $42,000 \mathrm{MW}-\mathrm{hr}$ for a projected capacity factor of 0.19 .

With an estimated generation of approximately $10 \mathrm{MW}$ providing $16650 \mathrm{MWhr}$, The Space Coast Next-Generation Solar Energy Center at Kennedy Space Center was commissioned on April 8, 2010, and funded by an innovative public-private partnership with NASA that leveraged engineering, design, and operating expertise. 
Table 4.2. Grid-connected PV installations by state ${ }^{a}$

\begin{tabular}{lcc}
\hline State & $\begin{array}{c}\text { Capacity installed in } \\
\mathbf{1 0 0}_{\mathbf{~ M W}}\end{array}$ & $\begin{array}{c}\text { Capacity installed in } \\
\text { total } \mathbf{~ M W}_{\mathbf{D C}}\end{array}$ \\
\hline Alabama & $b$ & 0.45 \\
Arkansas & $b$ & 0.12 \\
Florida & 46.15 & 49.6 \\
Georgia & $b$ & 0.91 \\
Kentucky & $b$ & 0.03 \\
Louisiana & $b$ & 0.35 \\
Mississippi & $b$ & 0.07 \\
North Carolina & 2.42 & 2.60 \\
South Carolina & 0.1 & 0.64 \\
Tennessee & 1.22 & 3.61 \\
Virginia & $b$ & 0.14 \\
West Virginia & $b$ & 0.14 \\
SE Subtotal & 49.89 & 58.66 \\
Maryland & $b$ & 0.07 \\
Missouri & $b$ & 2.24 \\
Oklahoma & 0.01 & 0.01 \\
Texas & 0.84 & 2.80 \\
$\quad$ Extended SE total & 50.74 & 63.78 \\
\hline
\end{tabular}

${ }^{a}$ Source: U.S. PV Installed-NREL

${ }^{b}$ Less than $100 \mathrm{kWDC}$ or data not available

The Martin Next-Generation Solar Energy Center (Indiantown, Florida) will be the second largest solar facility in the world and the largest solar plant of any kind outside of California. The facility will also be the first hybrid facility in the world to connect a solar facility to an existing combined-cycle power plant, providing $75 \mathrm{MW}$ of solar thermal capacity in an innovative way that directly displaces fossil fuel usage. The project will consist of up to about 200,000 parabolic trough mirrors over about 500 acres generating temperatures of more than $700^{\circ} \mathrm{C}$. Construction of the plant is under way with an in-service date scheduled late 2011. The estimated electricity generation is $155,000 \mathrm{MWhr} / \mathrm{year}$, and the total cost will be $\$ 476.3$ million or $\$ 6,350 / \mathrm{kW}$.

Conventional wisdom holds that solar plants using mirrors - which generate heat that produces steam that, in turn, spins an electrical generator-are not practical in Florida or the Southeast because of the regularity of afternoon rain clouds much of the year. The "thermal" solar plant is on a site near Lake Okeechobee, which already has 13 generators fueled by oil and natural gas. Steam from the solar plant will be combined with steam produced with the heat exhaust from four natural-gas plants to spin an existing generator, thus reducing the fluctuation effects. Hence, being hybrid makes solar thermal more feasible, because of the reduced fluctuation in temperatures and because the utility does not have to purchase a separate dedicated generator for the solar plant.

\subsection{COST OF SOLAR POWER}

\subsubsection{Photovoltaics (EERE Costs Solar PV)}

The cost of electricity from PV systems has dropped 15- to 20-fold; and grid-connected PV systems currently sell for about $\$ 5-\$ 10$ per peak watt (nominally 20 to 40 cents $/ \mathrm{kWhr}$ at $5 \% /$ year cost of capital and 0.15 capacity factor), including support structures, power conditioning, and land. They are highly 
reliable and last 20 years or longer. Hundreds of applications are cost-effective for off-grid needs. However, the fastest growing segment of the market is grid-connected PV, such as roof-mounted arrays on homes and commercial buildings in the United States. California and other states are currently subsidizing PV systems because it is considered cost-effective to reduce their peak daytime loads for airconditioning, which matches PV output.

On Feb. 24, 2009, First Solar, Inc., announced it had reduced its manufacturing cost for solar modules in the fourth quarter to 98 cents per watt, breaking the \$1-per-watt price barrier. At that time comparable costs for standard silicon panels were hovering in the $\$ 3$ range, so it was tempting to conclude that cadmium telluride (CdTe) technology of First Solar had won the race. But scaling up the CdTe technology until it is competitive with conventional generation is not a foregone conclusion. A study authored by M. Taylor et al. from the University of California-Berkeley and Lawrence Berkeley National Laboratory suggests that neither CdTe nor Si based materials have what it takes compared to lesserknown alternatives (Taylor et al., 2007).

Most solar manufacturer's are trying to achieve "grid parity," that is, making solar power cost the same as competing conventional power sources without subsidies. Getting manufacturing costs down to $\$ 0.65$ to $\$ 0.70$ per watt and other installation costs down to $\$ 1$ a watt would achieve this goal ( 7.5 cents/kWhr) with return-on-investment costs of $8 \% /$ annum and a capacity factor of $20 \%$.

The question raised by Wadia was whether any manufacturer would be able to handle the flood of orders that would ensue if they reached competitive cost. At that point, it comes down to a matter of having enough of raw materials. The Wadia paper evaluated the global supplies and extraction costs for 23 promising PV semiconductor materials and found that the three materials that currently dominate the market - silicon, CdTe, and another thin-film technology based on copper indium gallium selenide (CIGS) - all have limitations when ordered in mass. While silicon is the second-most abundant element in the Earth's crust, it requires enormous amounts of energy to convert into a usable crystalline form. This is a fundamental thermodynamic barrier that will keep silicon costs comparatively high. Both CIGS and CdTe rank poorly in abundance and extraction cost, with CdTe ranking dead last in long-term potential based on current annual extraction rates.

That does not mean these materials will not play a significant role, but additional R\&D will be required to develop materials such as iron pyrite, copper sulfide, and copper oxide to commercial or grid parity. The problem with these materials is that they are less efficient in converting the sun's rays to electricity, and as a result have been the focus of considerably less research. But the Berkeley study accounts for this fact and concludes that lower-efficiency materials that are cheaper and more abundant will ultimately serve the alternative energy market better.

Figure 4.3 presents a graphical overview of the efficiency, system cost, and energy costs from the present major technologies. While the trends are correct, grid parity with these concepts may not be possible until well past 2020.

\subsubsection{Thermal Concentrators (EERE Costs Solar Concentrators)}

Solar power from thermal concentrators is otherwise known as concentrating solar power (CSP). The true costs of CSP plants are hard to estimate at present as very few are being built. (The FPL Martin Plant solar components come in at $\$ 6.35 / \mathrm{W}$, but this does not include turbine/generator cost.) The economies of scale of CSP plants dictate that systems of tens of megawatts in size must be constructed to obtain competitive costs. At present the industries and markets needed to support the construction of new plants are not well developed, and it is exceeding difficult to satisfy the financial conditions needed for new construction, although a few new commercial projects promise to clear the path somewhat. The cost curve in Fig. 4.4 assumes that these barriers to new CSP plant construction can be overcome. 
PV System Efficiency

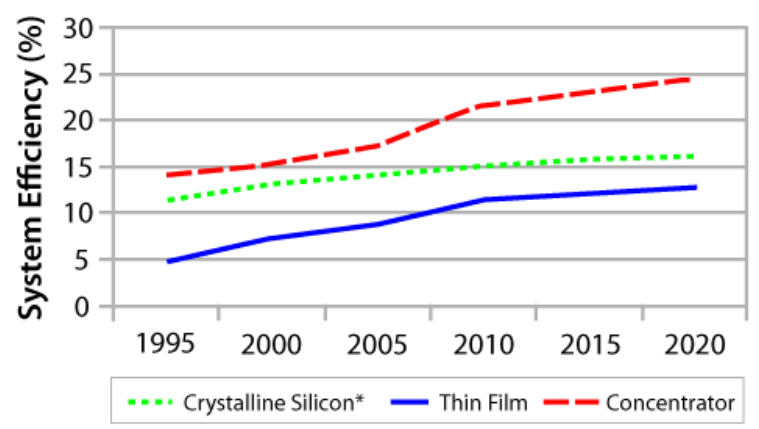

PV System Capital Cost

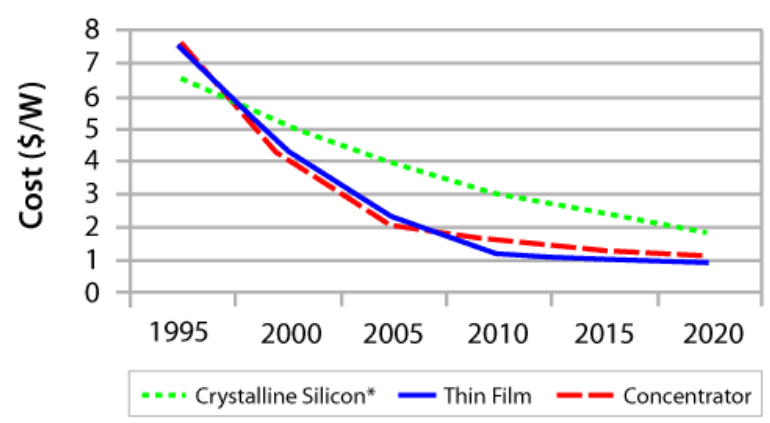

PV Cost of Energy

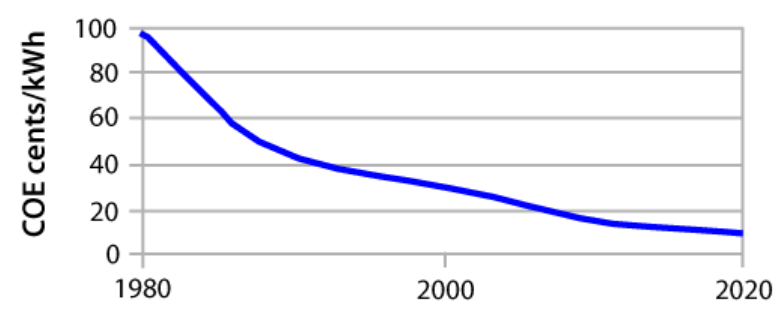

Fig. 4.3. PV efficiency, capital, and energy cost projections for classic solar PV materials.

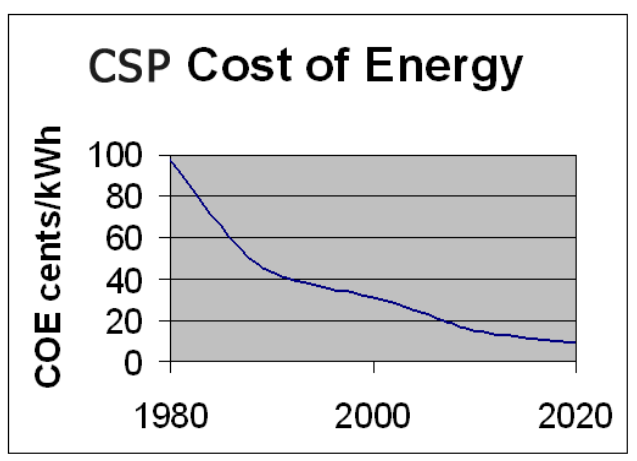

Fig. 4.4. Concentrating solar power cost. 


\subsection{SOLAR ENVIRONMENTAL IMPACTS (UCS CLEAN ENERGY TECHNOLOGY)}

Since solar power systems generate no air pollution during operation, the primary environmental, health, and safety issues involve how they are manufactured, installed, and ultimately disposed of. Energy is required to manufacture and install solar components, and any fossil fuels used for this purpose will generate emissions. Thus, an important question is how much fossil energy input is required for solar systems compared to the fossil energy consumed by comparable conventional energy systems. Although this varies depending upon the technology and climate, the energy balance is generally favorable to solar systems in applications where they are cost-effective, and it is improving with each successive generation of technology. According to some studies, for example, solar water heaters increase the amount of hot water generated per unit of fossil energy invested by at least a factor of two compared to natural gas water heating and by at least a factor of eight compared to electric water heating.

Materials used in some solar systems can create health and safety hazards for workers and anyone else coming into contact with them. In particular, the manufacturing of PV cells often requires hazardous materials such as arsenic and cadmium. Even relatively inert silicon, a major material used in solar cells, can be hazardous to workers if it is breathed in as dust. Workers involved in manufacturing PV modules and components must consequently be protected from exposure to these materials. There is an additional — probably very small — danger that hazardous fumes released from PV modules attached to burning homes or buildings could injure firefighters.

None of these potential hazards is much different in quality or magnitude from the innumerable hazards people face routinely in an industrial society. Through effective regulation, the dangers can very likely be kept at a very low level.

The large amount of land required for utility-scale solar power plants - approximately $1 \mathrm{~km}^{2}$ for every 20-60 MW generated - poses an additional problem, especially where wildlife protection is a concern. But this problem is not unique to solar power plants. Generating electricity from coal actually requires as much or more land per unit of energy delivered if the land used in strip mining is taken into account. Solar-thermal plants (like most conventional power plants) also require cooling water, which may be costly or scarce in desert areas.

However, large central power plants are not the only option for generating energy from sunlight and may well be the least promising. Because sunlight is dispersed, small-scale, dispersed applications are a better match to the resource. They can take advantage of unused space on the roofs of homes and buildings and in urban and industrial lots. And, in solar building designs, the structure itself acts as the collector, so there is no need for any additional space at all.

The Office of Energy Efficiency and Renewable Energy (EERE) of the Department of Energy (DOE) and the Bureau of Land Management (BLM) of the Department of the Interior (DOI) are preparing a Programmatic Environmental Impact Statement (PEIS) to evaluate utility-scale solar energy development, to develop and implement agency-specific programs that would establish environmental policies and mitigation strategies for solar energy projects, and to amend relevant BLM land-use plans with the consideration of establishing a new BLM solar energy development program. More information on the Programmatic Environmental Impact Statement (PEIS) can be found at http://www.doi.gov/news/09_News_Releases/SolarEnergyQA.pdf.

\subsubsection{Solar Reliability}

Modern solar electric systems have been shown to be very reliable. With no moving parts, the reliability hinges on warranties of key components. Most solar PV modules have warranties of 25-30 years, at which time their output is warranted to be $80 \%$ of the day they were installed. Solar PV systems are given service lifetimes between $30-50$ years.

Modern inverters also have minimum warranties of 5 years with some manufacturers increasingly offering 10 year warranties. Realistically, there will be some solar modules that fail "out of the box," but these are spotted immediately by the installer. Some inverters have also failed quickly but are quickly 
replaced. As more systems get "real experience" on rooftops, more definitive information about solar reliability will become available.

The power rating shown on the nameplate of a PV panel reflects performance under standard test conditions (STC) of $1000 \mathrm{~W} / \mathrm{m}^{2}$ solar irradiance and $25^{\circ} \mathrm{C} \mathrm{PV}$ module temperature.

As part of the California Solar Initiative, many panels are also tested under PVUSA Test Conditions (PTC). PTC watt rating is based on $1000 \mathrm{~W} / \mathrm{m}^{2}$ solar irradiance, $20^{\circ} \mathrm{C}$ ambient temperature, and $1 \mathrm{~m} / \mathrm{sec}$ wind speed. The PTC watt rating is lower than the STC.

\subsection{CONCLUSIONS}

Solar insolation in the Southeast and extended Southeast is not as extensive or intense as in the some states in the Southwest or in California. As a result, the use of solar PV and solar thermal collectors will require larger arrays to provide the same total energy $(\mathrm{kWh})$ and capacity $(\mathrm{kW})$ in the Southeast. This increases total installed solar cost for PV by about $15 \%$, which tends to slow solar penetration in the Southeast.

Nevertheless, both solar PV and thermal collector systems are being installed in the Southeast, mainly in Florida. The total installed PV capacity is now estimated to be about $63.8 \mathrm{MW}_{\mathrm{DC}}$ with the vast majority of this in Florida (49.6 $\mathrm{MW}_{\mathrm{DC}}, 46.15 \mathrm{MW}_{\mathrm{DC}}>100 \mathrm{MW}$ ). Similarly for collector systems, the FPL hybrid plant provides $75 \mathrm{MW}$ of added thermal capacity.

Given the high cost and lower solar insolation in the Southeast, solar energy cannot be realistically expected to provide a significant contribution to renewable capacity for at least another decade. As a result, this study conservatively assumes no significant solar contribution to renewable generation in the Southeast prior to 2030. Basically, a breakthrough to cost-effective non-silicon based technology will be required.

\subsection{REFERENCES}

Taylor, M., et al. 2007. Government Actions and Innovation in Clean Energy Technologies: The Cases of Photovoltaic Cells, Solar Thermal Electric Power, and Solar Water Heating, California Energy Commission, CEC-500-2007-012, October.

\subsection{ADDITIONAL RESOURCES}

Solarbuzz-Photovoltaic Industry Statistics: Costs (Solarbuzz Cost Statisics), http://www.solarbuzz.com./ StatsCosts.htm

Sherwood, Larry. “U.S. Solar Market Trends 2007,” August 2008, Interstate Renewable Energy Council

A Performance Calculator for Grid-Connected PV Systems, The Renewable Resource Data Center (RReDC), National Renewable Energy Laboratory, http://rredc.nrel.gov/solar/calculators/ PVWATTS/version1/

"Cost of Installed Solar Photovoltaic Systems Drops Significantly over the Last Decade," ScienceDaily (Mar. 3, 2009). http://www.sciencedaily.com/releases/2009/02/090219152130.htm 



\section{BIOMASS}

Biomass as a renewable energy resource has received increased attention in the search for clean, renewable energy alternatives. Biomass is flexible and can be (1) used as fuel for direct combustion, (2) gasified, (3) used in combined heat and power technologies, or (4) used in biochemical conversions. Because of the wide range of feedstocks, biomass has a broad geographic distribution. Regionally the Southeast region produces nearly $40 \%$ of the nation's biomass energy resource.

Biomass is already making key energy contributions in the United States and has surpassed hydropower as the largest domestic source of renewable energy. Biomass currently supplies over $4 \%$ of the total United States energy consumption - mostly through industrial heat and steam production by the pulp and paper industry and electrical generation with forest industry residues and municipal solid waste (MSW) (EIA, 2010). It is the only current renewable source of liquid transportation fuel, making it an invaluable way to reduce oil imports. Biomass could also provide heat and power to industry and provide feedstocks for a wide range of chemicals and materials or bioproducts.

This analysis draws heavily on the work of many research organizations and individual researchers. In particular, the work of the Oak Ridge National Laboratory in collaboration with researchers from the U.S. Department of Agriculture (USDA) Forest Service, USDA Agricultural Research Service, universities, and other laboratories (Perlack and Stokes, 2011). This work is an update to the ORNL/USDA study (Perlack et al., 2005) on the technical feasibility of an annual billion-ton biofuels industry. The update to the billion-ton study provides a spatial, county-by-county inventory of primary feedstocks, price, and available quantities (e.g., supply curves) for these individual feedstocks, and a more rigorous treatment and modeling of resource sustainability. A separate database containing the disaggregated biomass supplies by county and state is available through a Web-based Bioenergy Knowledge Discovery Framework for users to capture, visualize, and analyze information on the complete bioenergy supply chain and the infrastructure needed to support that chain (http://bioenergykdf.net). The analysis in this chapter also draws on work by the National Renewable Energy Laboratory (Milbrandt, 2005) for biomass resources not specifically addressed in the billion-ton update study. Milbrandt estimated biomass resources based on numerous assumptions, methodologies adopted from other studies, and factors that relate population to the amount of post-consumer residue generation. Finally, this section utilizes results of the recent Southern Bioenergy Roadmap by the Southeastern Agriculture and Forestry Energy Resources Alliance (Pennock, 2009). The SAFER Roadmap estimates that an established bioenergy resource in the Southeast would provide greater than 110,000 jobs with an annual output of $\$ 7,246 \mathrm{M}$ of product and labor income of $\$ 4,300 \mathrm{M}$.

As biofuel suppliers, the southern states' strengths are the amounts and spatial distribution of biofuels produced as well as support through a variety of state incentives and research. However, there are numerous barriers to deployment including the cost and availability of bioenergy feedstock, lack of public policy, and lack of public understanding.

The Biomass Research and Development Act of 2000 created the Biomass R\&D Technical Advisory Committee to provide advice to the Secretaries of Agriculture and Energy on program priorities and to facilitate cooperation among various federal and state agencies, and private interests. The Technical Advisory Committee established a national vision for bioenergy and biobased products (BTAC, 2002) as follows.

- Biopower-Biomass consumption in the industrial sector will increase at an annual rate of $2 \%$ through 2030, increasing from 2.7 quads in 2001 to 3.2 quads in 2010, 3.9 quads in 2020, and 4.8 quads in 2030. Additionally, biomass consumption in electric utilities will double every 10 years through 2030. Combined, biopower will meet $4 \%$ of total industrial and electric generator energy demand in 2010 and $5 \%$ in 2020. 
- Biobased Transportation Fuels-Transportation fuels from biomass will increase significantly from $0.5 \%$ of U.S. transportation fuel consumption in 2001 ( 0.0147 quad) to $4 \%$ of transportation fuel consumption in 2010 (1.3 quads), 10\% in 2020 (4.0 quads), and $20 \%$ in 2030 .

- Biobased Products-Production of chemicals and materials from biobased products will increase substantially from approximately 12.5 billion pounds or $5 \%$ of the current production of target U.S. chemical commodities in 2001 , to $12 \%$ in $2010,18 \%$ in 2020 , and $25 \%$ in 2030 .

The goal is equivalent to $30 \%$ of current petroleum consumption and will require more than approximately 1 billion dry tons of biomass feedstock annually - a fivefold increase over the current consumption.

Perlack et al. (2005) established that the land resources of the United States have the potential to produce a sustainable supply of biomass that can displace $30 \%$ of the country's current petroleum consumption. The report did not attempt to outline R\&D and policy agendas or attempt to assess the economic competitiveness of a billion-ton bioenergy and bioproducts industry, and its potential impacts on the energy, agriculture (food and feed production), and forestry sectors of the economy. Many of these questions were addressed in an interagency report sponsored by the Biomass Research and Development Initiative (BRDI, 2008). This report attempted to address four specific questions regarding biomass feedstocks - what feedstocks and at what prices, what is the spatial distribution of feedstocks, what are the effects of alternative investments in research, and what are the consequences for environmental sustainability including greenhouse gases related to feedstock production.

The biofuels resources for the extended southern states can be extracted from the above-mentioned studies, as shown in Table 5.1. The table also includes an estimate of the potential of dedicated energy crops. These crops would include perennial grasses, most notably switchgrass, woody crops such as poplar, pine and eucalyptus, and annual energy crops such as high-yield sorghum that could be grown in rotation with conventional agricultural crops. The estimate provided in Table 5.1 would correspond to what might be available in year 2020 under the presumption of a mature biofuels industry.

The proportional shares of extended southeastern resources are shown in Fig. 5.1. Energy crop potential is large in the southern states as are forest residues (mostly logging residues and thinnings). Crop residues are also a large resource. Although methane from wastes is relatively small, it is a higher quality fuel (both higher heat content and lower emissions) and can be used to fuel a gas turbine or more favorably a combined-cycle power plant, which has a relatively low heat rate (higher efficiency).

Using heat content values from Luke-Morgan (2008), best engineering estimates for heat rates, and a $70 \%$ capacity factor, it is possible to develop an estimate of the total biofuels resource in terawatt-hours and gigawatt capacity. The inputs values are shown in Table 5.3 and graphically in Fig. 5.2. Clearly not all biofuels would be used for power generation, but in keeping with the national goals set by the Biomass R\&D Technical Advisory Committee, about 5\% of generation in the Southeast could be met using biofuels as a primary fuel. Note that an aggressive program to use methane from municipal waste in combined-cycle plants would contribute significantly to the $5 \%$ generation goal.

Some studies convert energy content of the biomass directly into electrical energy units using a heat rate of $3417 \mathrm{BTU} / \mathrm{kWh}$. It is more correct to give energy content values in mmBTU or mmBTU/drytonne. Using $3417 \mathrm{BTU} / \mathrm{kWhr}$ is equivalent to saying that the biomass can be converted to electricity at $100 \%$ efficiency. As a result, some studies get three to four times the true electrical energy equivalent. Table 5.3 provides a better analysis but still requires a heat rate and capacity factor estimate to arrive at realistic energy and capacity figures.

At present about $2.4 \%$ of electric generation is from biomass ( 0.9 Quad of 38.2 input and 11.9 generated). While the majority of electric generation is from cogeneration facilites, such as paper, furniture, or chemical plants, there are some dedicated steam electric generation units fueled by biomass. It should be noted that heat rates for these non-combined cycle plants steam genertors are generally higher than for those for coal- or natural-gas-fired units. However, by co-firing with coal or petroleum coke and 
Table 5.1. Extended southern states biofuels resources in 1000 tonnes/year

\begin{tabular}{|c|c|c|c|c|c|c|c|}
\hline State & $\begin{array}{l}\text { Crop } \\
\text { residues }\end{array}$ & $\begin{array}{l}\text { Forest } \\
\text { residues }\end{array}$ & $\begin{array}{l}\text { Forest mill } \\
\text { residues }\end{array}$ & $\begin{array}{c}\text { Urban } \\
\text { wood } \\
\text { wastes }\end{array}$ & $\begin{array}{c}\text { Methane } \\
\text { from } \\
\text { wastes }\end{array}$ & $\begin{array}{l}\text { Energy } \\
\text { crops }\end{array}$ & Total \\
\hline Alabama & 198 & 2,266 & 648 & 445 & 337 & 2,344 & 6,237 \\
\hline Arkansas & 4,137 & 2,224 & 81 & 276 & 187 & 3,051 & 9,958 \\
\hline $\mathrm{DC}$ & - & - & - & 52 & 1 & - & 53 \\
\hline Florida & 1,510 & 1,379 & 212 & 1,927 & 502 & 1,932 & 7,462 \\
\hline Georgia & 857 & 3,283 & 189 & 980 & 354 & 2,051 & 7,715 \\
\hline Kentucky & 698 & 1,612 & 120 & 407 & 291 & 481 & 3,609 \\
\hline Louisiana & 1,603 & 2,530 & 67 & 418 & 179 & 3,113 & 7,910 \\
\hline Maryland & 392 & 188 & 60 & 556 & 219 & 448 & 1,863 \\
\hline Mississippi & 964 & 2,774 & 191 & 281 & 170 & 2,903 & 7,284 \\
\hline Missouri & 1,779 & 1,324 & 250 & 570 & 402 & 838 & 5,162 \\
\hline North Carolina & 780 & 2,960 & 33 & 878 & 810 & 3,570 & 9,031 \\
\hline Oklahoma & 993 & 454 & 30 & 347 & 206 & 6,869 & 8,900 \\
\hline South Carolina & 340 & 1,819 & 71 & 425 & 218 & 1,194 & 4,067 \\
\hline Tennessee & 428 & 1,400 & 357 & 598 & 303 & 3,701 & 6,787 \\
\hline Texas & 3,866 & 2,159 & 210 & 2,432 & 937 & 11,175 & 20,779 \\
\hline Virginia & 504 & 2,236 & 68 & 769 & 310 & 2,917 & 6,804 \\
\hline West Virginia & 15 & 961 & 272 & 169 & 51 & 59 & 1,528 \\
\hline Total Southeast & 19,065 & 29,570 & 2,860 & 11,530 & 5,477 & 46,648 & 115,149 \\
\hline
\end{tabular}

Notes: All resource estimates are from ORNL (2011) except for methane from wastes. These estimates are from Milbrandt (2005). Energy crops represent a year 2020 potential and include a mix of perennial grasses (e.g., switchgrass), woody crops (e.g., poplar and pine), and annual energy crops, such as high-yield sorghum. The ORNL (2011) estimates are based on a feedstock price of $\$ 60 /$ dry ton exclusive of supply-chain costs beyond the farmgate, forest roadside, or point of collection.

Table 5.2. Extended southern states contribution to the national total biofuels resource

\begin{tabular}{|c|c|c|c|c|c|c|c|}
\hline & $\begin{array}{c}\text { Crop } \\
\text { residues }\end{array}$ & $\begin{array}{l}\text { Forest } \\
\text { residues }\end{array}$ & $\begin{array}{l}\text { Forest mill } \\
\text { residues }\end{array}$ & $\begin{array}{c}\text { Urban } \\
\text { wood } \\
\text { wastes }\end{array}$ & $\begin{array}{c}\text { Methane } \\
\text { from } \\
\text { wastes }\end{array}$ & $\begin{array}{l}\text { Energy } \\
\text { crops }\end{array}$ & Total \\
\hline U.S. total & 111,202 & 53,728 & 6,701 & 28,737 & 13,636 & 80,534 & 294,539 \\
\hline $\begin{array}{l}\text { Southeast } \\
\text { SE as \% of U.S. }\end{array}$ & 19,065 & 29,570 & 2,860 & 11,530 & 5,477 & 46,648 & 115,149 \\
\hline total & $17 \%$ & $55 \%$ & $43 \%$ & $40 \%$ & $40 \%$ & $58 \%$ & $39 \%$ \\
\hline
\end{tabular}




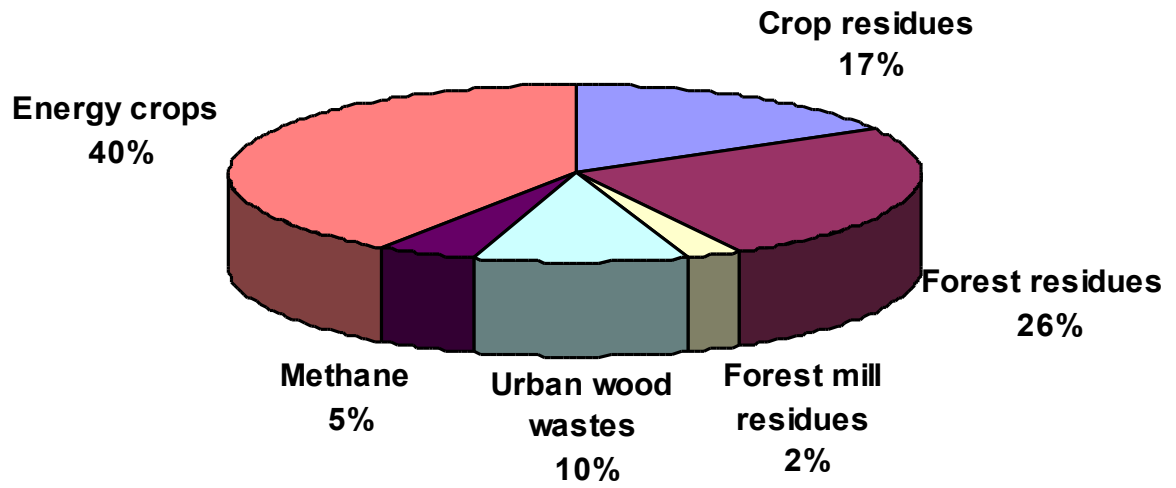

Fig. 5.1. Extended southeastern states biofuels.

Table 5.3. Extended southeastern states biofuels resource in terawatt-hour and gigawatt capacity

\begin{tabular}{lrrrrrrr}
\hline & $\begin{array}{c}\text { Crop } \\
\text { residues }\end{array}$ & $\begin{array}{c}\text { Forest } \\
\text { residues }\end{array}$ & $\begin{array}{c}\text { Forest mill } \\
\text { residues }\end{array}$ & $\begin{array}{c}\text { Urban } \\
\text { wood } \\
\text { wastes }\end{array}$ & $\begin{array}{c}\text { Methane } \\
\text { from } \\
\text { wastes }\end{array}$ & $\begin{array}{c}\text { Energy } \\
\text { crops }\end{array}$ & Total \\
\hline mmBTU/dry tonne & $\mathbf{1 4}$ & $\mathbf{1 4}$ & $\mathbf{9}$ & $\mathbf{8}$ & $\mathbf{1 8}$ & $\mathbf{1 4}$ \\
Heat rate, & & & & & & & \\
BTU/kW-hr & $\mathbf{1 2 0 0 0}$ & $\mathbf{1 2 0 0 0}$ & $\mathbf{1 2 0 0 0}$ & $\mathbf{1 2 0 0 0}$ & $\mathbf{6 0 0 0}$ & $\mathbf{1 2 0 0 0}$ \\
Cap factor & $\mathbf{7 0 \%}$ & $\mathbf{7 0 \%}$ & $\mathbf{7 0 \%}$ & $\mathbf{7 0 \%}$ & $\mathbf{8 5 \%}$ & $\mathbf{7 0 \%}$ & 54 \\
TWhr & 22 & 34 & 2 & 8 & 16 & 137 \\
GW & 16 & 24 & 2 & 5 & 14 & 38 & 99 \\
\hline
\end{tabular}

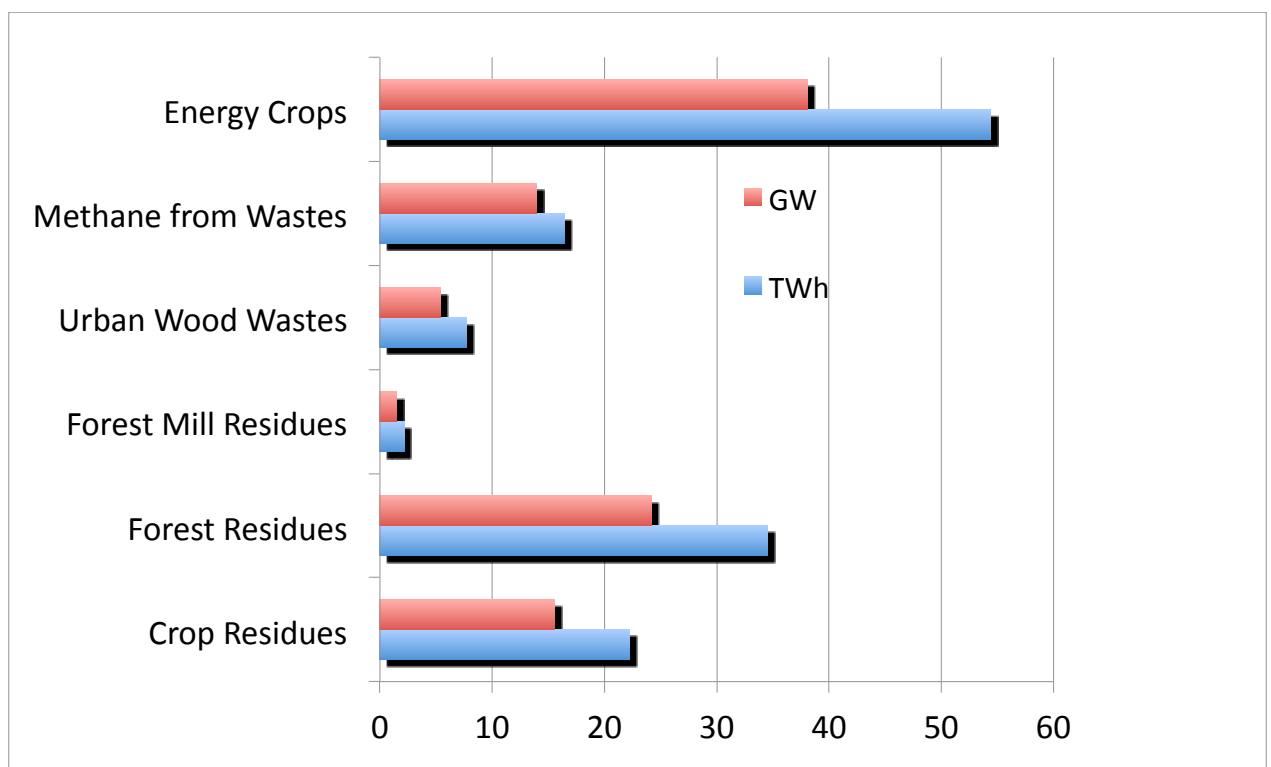

Fig. 5.2. Extended southeastern states biofuels resource potential for generation in terawatt-hour and gigawatt capacity. 
using fluidized-bed combustion, some new units have much lower heat rates. A good example is the Altavista Power Station (Altavista) with a calculated 7337 Btu/kwh heat rate (Altavista, 2011).

In addition to wood waste products, wood chips and densified wood pellets are used as fuel for commercial/industrial heating and electric power generation. Wood pellets are an attractive fuel because their uniform size and shape facilitate automated handling, and they have an energy value approximately 1.5 times that of normal wood. Because of higher conventional fuel costs, wood pellets have emerged as an export commodity for southeastern states. There are currently a total of 24 pellet fuel manufacturers in the South, including five in Arkansas, four in Georgia, three in Kentucky, and three in Virginia (Altavista, 2011).

Use of biomass for energy is an attractive economic development opportunity. By substituting locally available resources for fuels imported from other regions of the United States and foreign countries, biomass communities can reduce "leakage" of financial resources, and therefore keep more money in the local economy. To indicate the potential benefits for economic development, the current economic impacts of using biomass fuels for industrial heat and electric power generation in the South were estimated in the SAFER study. Using an input-analysis model, economic contributions of biomass power and energy production in the South in 2007 were estimated and summarized in Tables 18 and 19 of the SAFER study. For all states in the region, total direct and indirect economic impacts included $\$ 7.3$ billion in output (revenues), $\$ 4.3$ billion in value added (personal and business income), and employment of over 110,000 workers (full time, part-time, seasonal). By industry sector, the agriculture and forestry sectors saw the greatest impacts, with over 60,000 jobs and $\$ 1.38$ billion in value added, representing the activities associated with biomass feedstock procurement.

Clearly biomass already contributes significantly to the renewable energy use in the southeastern states and has the potential for even larger utilization in the future.

\subsection{CONCLUSIONS}

Biomass will continue to contribute a significant portion to the total renewable energy available and utilized in the Southeast. The resource is available and the technology to utilize it exists and is being improved annually.

\subsection{REFERENCES}

Altavista Power Station. 2011. Tables 10, 11, 18, and 19, SAFER Report, http://www.dom.com/about/stations/ renewable/biomass-stations.jsp.

BRDI (Biomass Research and Development Initiative). 2008. Increasing feedstock production for biofuels: economic drivers, environmental implications, and the role of research, Washington, DC, $146 \mathrm{p}$.

BTAC (Biomass Technical Advisory Committee). 2002. "Vision for Bioenergy \& Biobased Products in the United States," http:// www.bioproducts-bioenergy.gov/pdfs/BioVision_03_Web.pdf (October).

EIA. December 2010. Monthly Energy Review.

Luke-Morgan, Aubrey. April 2008. "The Impact on Georgia Biomass for Feedstock from Rising Input and Transportation Costs in 2008."

Milbrandt, A. December 2005. A Geographic Perspective on the Current Biomass Resource Availability in the United States, MILBRANDT/TP-560-39181.

Pennock, Charity, et al. 2009. "Southern Bioenergy Roadmap" (Southeastern Agriculture and Forestry Energy Resources Alliance (SAFER).

Perlack, Robert D., et al. April 2005. Biomass as Feedstock for A Bioenergy and Bioproducts Industry: The Technical Feasibility of a Billion-Ton Annual Supply, ORNL/TM-2005 or DOE/GO-1029952135. 
Perlack, R. D., Stokes, B. J. 2011. Biomass as Feedstock for a Bioenergy and Bioproducts Industry: An Update to the Billion-Ton Annual Supply, ORNL/TM report, Oak Ridge National Laboratory, Oak Ridge, TN, forthcoming. 


\section{HYDROPOWER}

In a March 2007 EPRI Report number entitled Assessment of Waterpower Potential and Development Needs, hydropower is referred to, as waterpower is electric energy derived from moving water (EPRI, 2007). Included in the technologies are conventional hydroelectric facilities and generation from emerging technologies that harness waterway currents (river, tidal, ocean, and constructed waterways). A technical categorization provided by Bedard (2006) suggests the following definitions.

- Hydrostatic energy is the energy possessed by a body because of its position or location at an elevation (or height, often called head) above a reference or datum, and the principle behind hydropower at dams.

- Hydrokinetic energy is derived from the Greek word for water (hydro) and kinetic (of, relating to, or provided by motion). Therefore, hydrokinetic energy is the energy possessed by a body of water because of its motion.

Initially included in this assessment of hydropower potential in the Southeast were both the hydrostatic waterpower technologies (conventional hydropower and pumped storage) and the newer hydrokinetic waterpower technologies (in-stream turbines (river, tidal, and constructed waterways) and ocean wave energy devices). The water resources considered are all natural or man-made freshwater bodies, estuarine tidal currents, ocean currents (e.g., Gulf Stream), and ocean waves. However, when considering the technological availability of the hydrokinetic resources in the 2020-2030 time frame, it quickly becomes clear that the potential for this resource is very limited. Hence, the energy potential of hydrokinetic and ocean thermal resources are not considered in this review because it is considered to be feasible only for periods well past the 2020 evaluation date for this review.

The conventional hydropower class definitions used in this review are those found in recent DOE publications (Hall et al., 2006). Detailed definitions of the next-generation hydrokinetic and ocean energy waterpower technologies are reviewed in EPRI (2007) and Bedard (2006).

In terms of existing technology, the following capacity definitions are used:

- Large conventional hydropower - capacity > 30 MW with nominally 66,500 MW installed nationally

- Small conventional hydropower-capacity from 1 to $30 \mathrm{MW}$ with nominally 8,000 MW installed nationally

- Low-power hydropower-capacity of $100 \mathrm{~kW}$ to $1 \mathrm{MW}$ with nominally $350 \mathrm{MW}$ installed nationally

- Micro-hydropower-capacity less than $100 \mathrm{~kW}$

Pumped-storage hydropower has an installed national capacity of approximately 21,000 MW. This form of energy storage uses reversible pump-turbine generators to move water from a lower reservoir to an upper reservoir at times when demand for electricity and marginal cost are low. During periods of high electrical demand and higher marginal cost, the water is released back to the lower reservoir to generate electricity. Its flexibility and support to the transmission system make it a very valuable energy storage resource. Because the energy used to pump the water to the upper reservoir relies on other power sources (usually fossil or nuclear but potentially renewable), it is only briefly discussed despite its critical role in supporting electric system reliability. Several of the potential sites mentioned are possibly both conventional hydro and pumped storage sites, and where possible these sites are identified.

During the course of the review, the original southeastern states were expanded to include Missouri, Oklahoma, and Texas. These states were also added to the southeastern states database (Excel spreadsheet) that was extracted from the INEL national database (hydro2.inel.gov, hydro2.inel.gov/resourceassessment/d/ihred-29apr03.xls). Maryland has no entries in the 2003 spreadsheet but did have entries in the 2006 hydro potential database (hydro2. inel.gov/ resourceassessment). 
The developed and potential hydro resource in megawatts is displayed in Fig. 6.1 and percent developed in Fig. 6.2 (Hall et al., 2006a). The total available resource is 5618 MWa developed and $6161 \mathrm{MWa}$ remaining potential. Alabama, Arkansas, Kentucky, Missouri, and Tennessee alone have about $42 \%$ of the undeveloped potential $(2561 \mathrm{MWa})$. The unit MWa is the average effective capacity of the hydro resource. Actual installed megawatts is about twice these numbers.

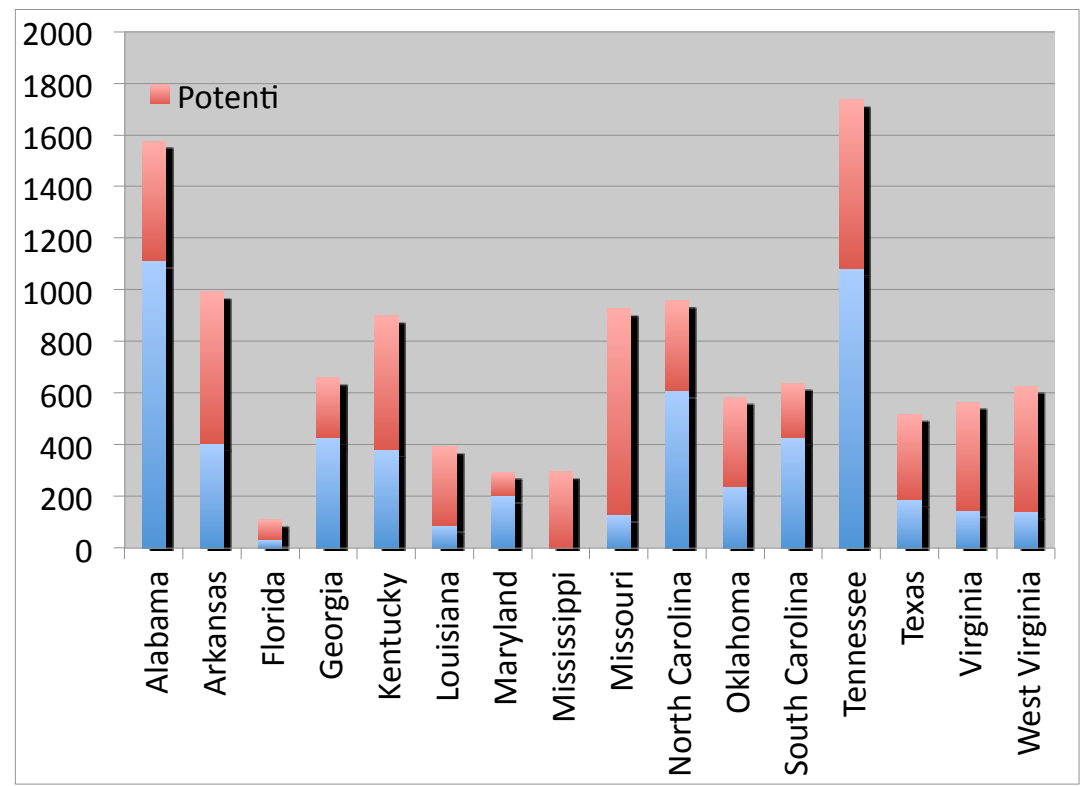

Fig. 6.1. Potential and developed hydro for expanded Southeast region.

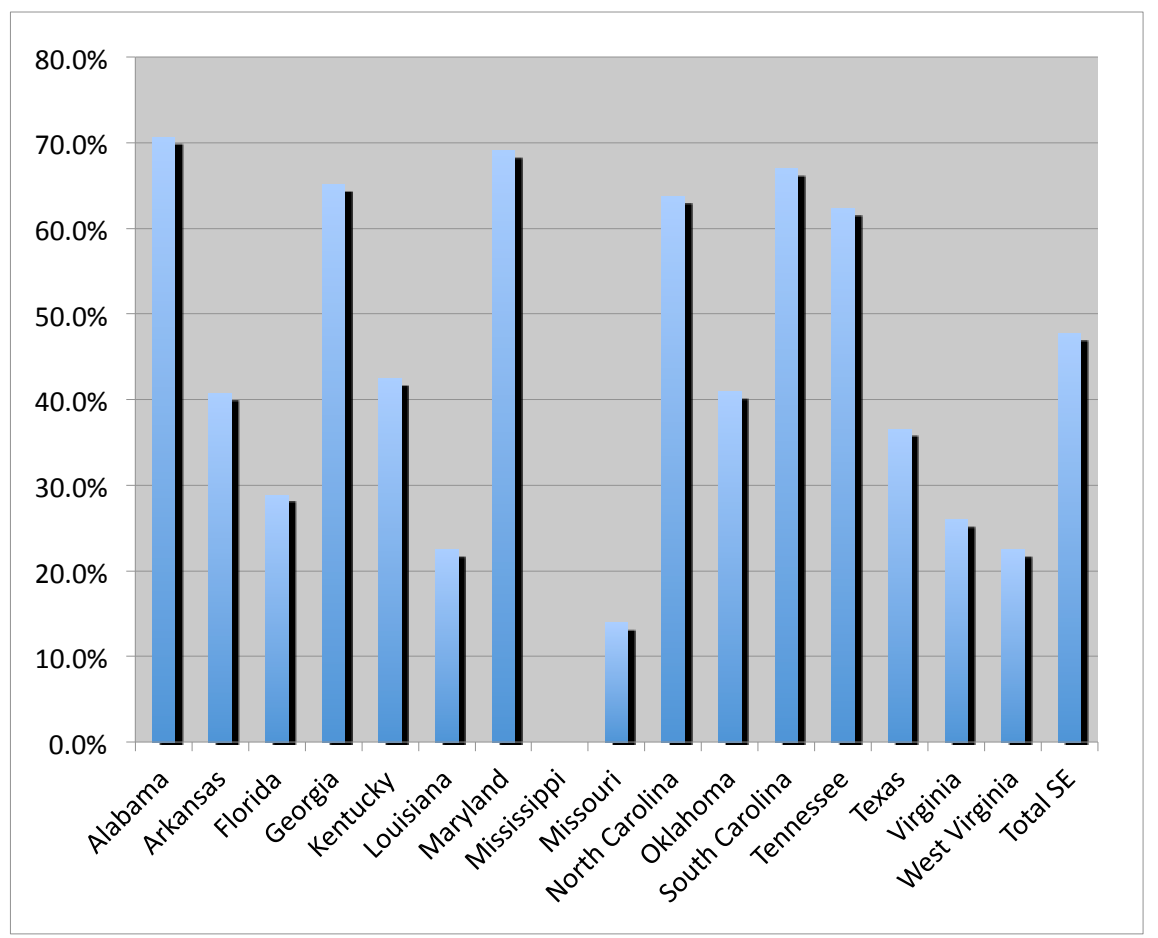

Fig. 6.2. Percent hydro developed by state in expanded Southeast region. 
Essentially all the hydro resource in the Southeast is conventional, being either run-of-river consisting of a conventional dam less than 10 feet high with limited storage or a storage type with a dam greater than 10 feet high and substantial storage capacity.

To go beyond the summary data presented in the INEL potential hydro report (Hall, 2006b) and present information about individual water energy resource sites and potential projects would be overly detailed. The data used and produced in the original INEL study were incorporated into a GIS application and made publicly available on the Internet. This application is called the Virtual Hydro Prospector, and is accessible at hydropower.inl.gov/prospector/.

An evaluation of the economic parameters used to estimate costs for hydro projects is found in Estimation of Economic Parameters of U.S. Hydropower Resources (Hall, July 2003). The parameters are expressed in 2003 dollars, which in most cases, were extrapolated from earlier costs. Because hydro is a well-established technology, the extrapolated values are valid today if escalated to 2010 or later values for future projects.

\subsection{CONCLUSIONS}

Essentially the hydro generation in the Southeast can be increased by about a factor of 2 from $5618 \mathrm{MWa}$ developed with $6161 \mathrm{MWa}$ remaining potential to approximately 11,800 MWa. This represents a nominal generation of $103.4 \mathrm{TWhr}$. At least $80 \%$ of the remaining potential could be installed by 2030 without any technical breakthrough for a total of 10550 MWa producing $92.4 \mathrm{TWhr}$.

\subsection{REFERENCES}

Bedard, Roger. 2006. Overview: EPRI Ocean Energy Program, presentation at Duke Global Change Center, September 14.

Dixon, Douglas A. 2007. The Future of Waterpower: 23,000 MW+ by 2025, EESI Briefing, June.

EPRI. 2007. Assessment of Waterpower Potential and Development Needs, 1014762, Palo Alto, California.

Hall, Douglas G., et al. 2006a. Feasibility Assessment of the Water Energy Resources of the United States for New Low Power and Small Hydro Classes of Hydroelectric Plants, Table 7, DOE-ID-11263, DOE/INEL, January.

Hall, Douglas G., et al. 2006b. Feasibility Assessment of the Water Energy Resources of the United States for New Low Power and Small Hydro Classes of Hydroelectric Plants, DOE-ID-11263, DOE/INEL, January.

Hall, Douglas G., et al. 2003. Estimation of Economic Parameters of U.S. Hydropower Resources, Idaho National Engineering and Environmental Laboratory, INEEL/EXT-03-00662. 



\section{GEOTHERMAL ENERGY IN THE SOUTHEAST}

The United States currently leads the world's countries in online geothermal energy capacity and continues to be one of the principal countries to increase its geothermal growth (U.S. Geothermal Power Production and Development Update, April 2010). In 2007 geothermal energy accounted for 4\% of renewable energy-based electricity consumption in the United States (DOE, 2008). As of April 2010, geothermal electric power generation is occurring in nine U.S. states: Alaska, California, Hawaii, Idaho, Nevada, New Mexico, Oregon, Utah, and Wyoming. Other states, such as Colorado, Louisiana, Mississippi, and Texas, are soon to be added to the list. The United States has a total installed capacity of $3086.6 \mathrm{MW}$ with 4584-7875 MW in development.

Projects under development in the Southeast are located in Louisiana, Mississippi, and Texas. Louisiana currently hosts two known developing geothermal projects. One, a $0.05 \mathrm{MW}$ project, is a planned geothermal hydrocarbon co-production (GHCP) unit at a producing gas field. Another 5.25 MW project, which has been awarded \$5 million in ARRA funding from the DOE Geothermal Technologies Program, will develop geopressured resources at an oil and gas field and is in the advanced stage of development. Mississippi's first developing geothermal project is rated at $0.05 \mathrm{MW}$ and is a planned GHCP unit at a producing oil field. The first geothermal project being developed in Texas is a $0.4 \mathrm{MW}$ planned GHCP unit. In addition to this project, DOE awarded \$32.4 million in ARRA funding to 13 recipients in Texas for research in areas such as enhance geothermal systems (EGS) R\&D and innovative exploration technologies.

Usable geothermal fluids are often found in oil and gas production fields as well as certain mining operations. Using low-temperature binary technology, the heat in "produced fluids" from oil and gas wells can be utilized to produce geothermal electricity. The Southern Methodist University Geothermal Energy Program has estimated that GHCP operations in the Texas Gulf Plains have the capability of providing 1000-5000 MW of power (McKenna, 2005).

In addition to GHCP, geopressured resources present another opportunity for geothermal development. Geopressured resources exist where deposits of natural gas form under very high pressure. The mechanical energy from pressurized natural gas, the natural gas itself, and the heat from the co-produced geothermal brine can be utilized to provide electricity as well as two separate revenue streams. While located in a number of states, the most significant resources are said to be located in the northern Gulf of Mexico, particularly Texas and Louisiana (offshore and onshore). The USGS has estimated that in addition to thousands of megawatts of geothermal energy, these resources hold as much as 1,000 TCF of potentially recoverable gas. Also, it is estimated that in Texas alone there exists a total geopressured resource of 5,100 EJ (Texas ECO, 2008). New GHCP and geopressured geothermal projects are beginning to be developed throughout the Great Plains and southern United States. The DOE recently provided \$8.2 million of ARRA funding to two GHCP projects and one geopressured project in three states-Nevada, Texas, and Oregon. The Texas project is located in Liberty County and is co-funded by Universal Geopower ( $\$ 2.1$ million) and DOE ( $\$ 1.5$ million). It is the most advanced of the GHCP projects.

Enhanced Geothermal Systems (EGS) commonly refers to any resource that requires artificial stimulation and includes resources that have to be fully engineered, or ones that produce hydrothermal fluid, but sub-commercially. In certain respects EGS is still a young and not fully proven technology. However, GTP recently provided \$73.5 million in federal funding to EGS demonstration projects in five different states. In addition to funding provided by DOE, the total industry cost share for these projects is $\$ 99.1$ million.

It is quite clear that no natural geothermal resources exist in the expanded southeastern states and that work on geopressured installations is just beginning. However, the potential for development of more advanced EGS projects that could provide a substantial amount of future energy resources requires further discussion. 
Perhaps the best reference regarding EGS is an MIT report entitled The Future of Geothermal Energy - Impact of Enhanced Geothermal Systems (EGS) on the United States in the 21st Century (MIT, 2008). This report includes resource assessments, estimated costs, and engineering estimates with appropriate equations.

Analyses prior to the MIT study suggested that the amount of thermal energy available for EGS development is enormous. However, these earlier works did not use detailed geologic information, and as a result, the methodologies employed and resulting resource estimates were, by necessity, somewhat simplified. The MIT study utilizes published geologic and geophysical data for the United States to calculate the stored thermal energy (or "heat in place") on both a national and state level, at depths from 3-10 km. The methodology, resource types considered, and the resource base calculations are included in Chapter 2 of the study. Recoverability, or useful energy, is discussed in Chapter 3. A depth of $3 \mathrm{~km}$ was selected as a cutoff for upper depth because, outside of the periphery of active magmatic and hydrothermal systems, temperatures in excess of $150^{\circ} \mathrm{C}$ at less than that depth are rare.

Several classes of geothermal resources are discussed (Table 2.1 of the study). In earlier analyses, the geothermal resource was divided into four major categories: hydrothermal, geopressured, magma, and conduction dominated (EGS or Hot Dry Rock). The resource classes in the MIT study were expanded to include (1) sedimentary EGS, (2) basement EGS, (3) geopressured-geothermal systems, and (4) coproduced fluids (hot aqueous fluids that are produced during oil and gas production). Brief mention is also made of supercritical/volcano (i.e., igneous) geothermal systems. While there is overlap in some of these categories, the MIT study provides adjustments as needed.

The MIT study shows the temperatures at a nominal drill depth of $10 \mathrm{~km}$ (a $1 \mathrm{~km}$ layer from 9.5-10.5 km). Temperatures exceed $150^{\circ} \mathrm{C}$ (yellow) over the vast majority of the Southeast and reach as high as $250^{\circ} \mathrm{C}$ in Texas, Louisiana, Arkansas, and Mississippi. The appendix to Chapter 2 of the MIT study enables one to estimate the extended Southeast EGS resource in EJ ( $10^{18}$ joules) at different drilling depths and extraction temperatures (Figs. 7.1 and 7.2). Assuming a plant life of 30 years, temperaturedependent thermal conversion efficiency, and an estimated extraction potential (taken as $10 \%$ for this analysis), one can estimate megawatt potential. The extraction potential is a very uncertain value estimated to range from $0.1 \%$ to $20 \%$.

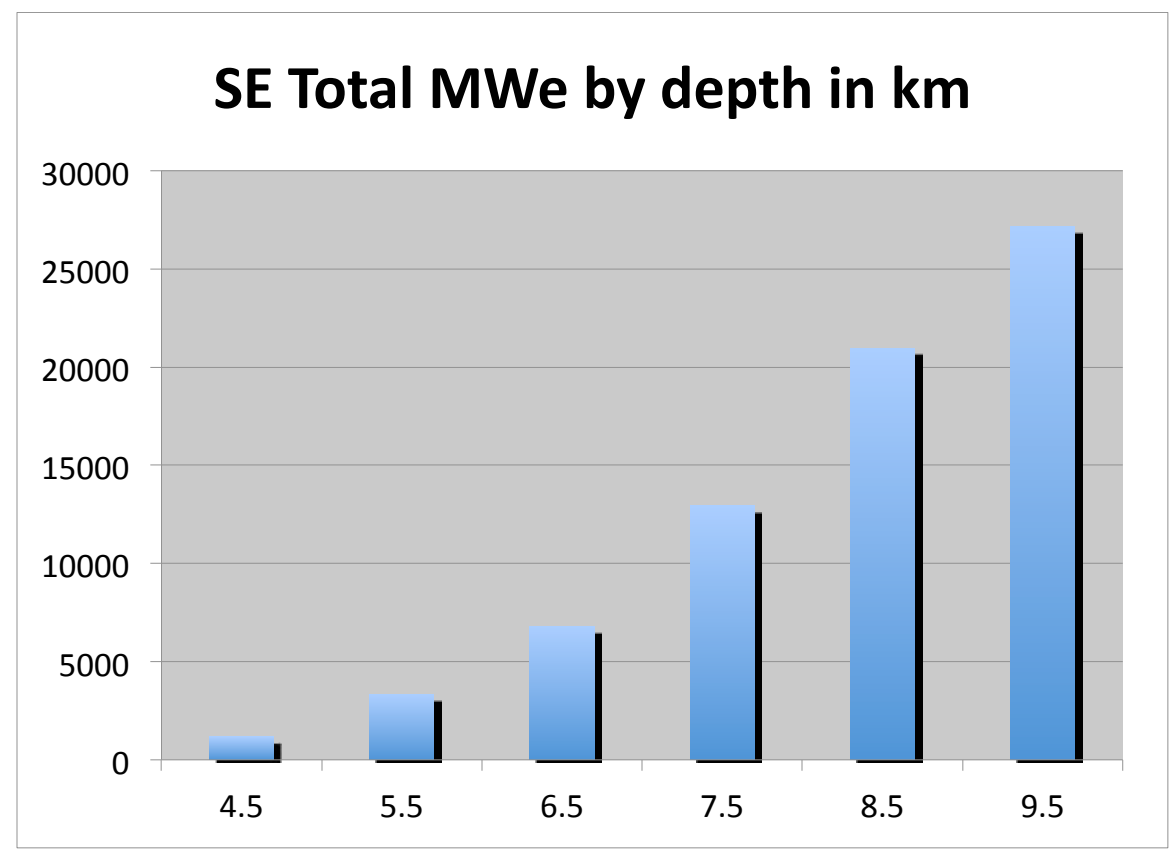

Fig. 7.1. Total megawatts-electrical potential at drill depth for $\mathbf{1 0 \%}$ recovery factor. Adapted from MIT (2008). 


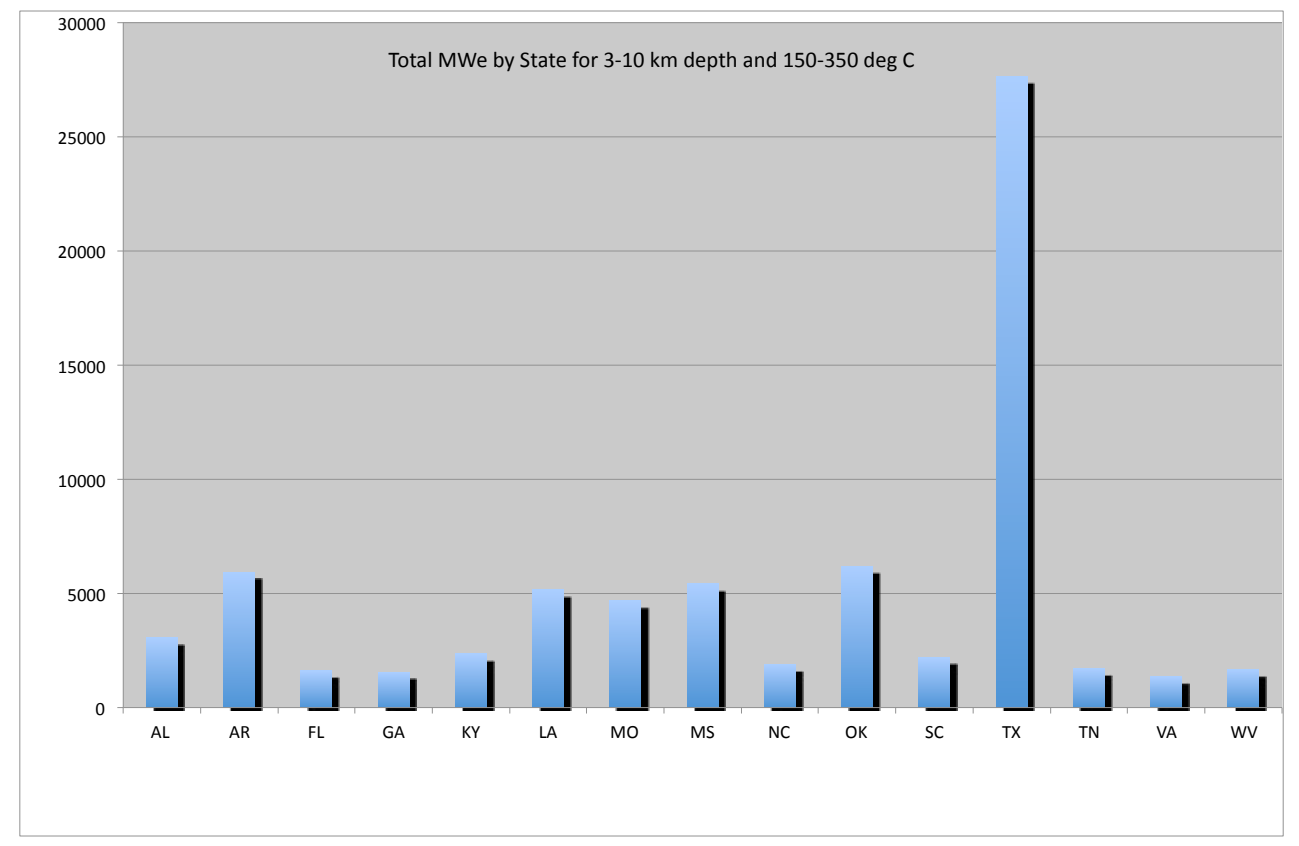

Fig. 7.2. Total megawatts-electrical potential by state for $\mathbf{1 0 \%}$ recovery factor. Adapted from MIT (2008).

Clearly greater drill depth results in more energy to extract but a higher temperature that results in better conversion efficiency, and a potentially lower cost plant also enhances this. The lower generating costs are offset by greater drilling costs. Texas is the dominant source, but it should be noted that offshore EGS is not considered in the analysis and may provide significant additional EGS.

The details of the calculation are shown in Tables 7.1 and 7.2.

Because of the uncertainty in the recovery factor, the values may range from 0.01 to 2 times larger. Until more experience is gained with the EGS resource, this uncertainty plus possible shorter lifetime $(<30$ years) may make EGS resources a very risky venture.

Cost for EGS plant includes licensing fees, well or drilling cost, and conversion equipment. The majority of the cost is associated with the three to four wells needed per site (one for injection and two to three for extraction). Chapter 6 of the MIT Study provides well cost estimates in 2004 dollars. Since the most effective depths for the Southeast are greater than 7,500 m, the cost ranges (2004 dollars) from

Table 7.1. Projected megawatts-electrical by state and well depth

\begin{tabular}{crrrrrrrr}
\hline $\begin{array}{c}\text { Depth } \\
\text { km/state }\end{array}$ & AL & AR & FL & GA & KY & LA & MO & MS \\
\hline 3.5 & 0 & 0 & 0 & 0 & 0 & 0 & 0 & 0 \\
4.5 & 1 & 148 & 0 & 0 & 0 & 266 & 0 & 35 \\
5.5 & 24 & 376 & 24 & 0 & 0 & 463 & 0 & 402 \\
6.5 & 224 & 658 & 105 & 2 & 0 & 639 & 2 & 801 \\
7.5 & 535 & 1284 & 195 & 253 & 70 & 1037 & 646 & 1092 \\
8.5 & 907 & 1623 & 302 & 414 & 1111 & 1224 & 1971 & 1433 \\
9.5 & 1361 & 1842 & 982 & 888 & 1170 & 1535 & 2077 & 1652 \\
Total & 3052 & 5931 & 1608 & 1557 & 2351 & 5164 & 4697 & 5415 \\
\hline
\end{tabular}


Table 7.2. Projected megawatts-electrical by state and well depth

\begin{tabular}{crrrrrrrr}
\hline $\begin{array}{c}\text { Depth } \\
\text { km/state }\end{array}$ & NC & OK & SC & TX & TN & VA & WV & Total \\
\hline 3.5 & 0 & 0 & 0 & 2 & 0 & 0 & 0 & 12 \\
4.5 & 0 & 0 & 0 & 756 & 0 & 0 & 0 & 1206 \\
5.5 & 3 & 67 & 0 & 1958 & 0 & 0 & 16 & 3335 \\
6.5 & 49 & 772 & 66 & 3370 & 10 & 24 & 82 & 6805 \\
7.5 & 201 & 1368 & 467 & 5177 & 109 & 203 & 298 & 12934 \\
8.5 & 597 & 1808 & 736 & 7277 & 522 & 439 & 609 & 20973 \\
9.5 & 1054 & 2167 & 916 & 9094 & 1082 & 686 & 674 & 27179 \\
Total & 1904 & 6182 & 2185 & 27633 & 1723 & 1352 & 1679 & 72444 \\
\hline
\end{tabular}

about $\$ 15$ million per well for 7,500 m depth to $\$ 20$ million per well for $10,000 \mathrm{~m}$ well. Hence well cost alone is a major portion of the EGS cost, ranging from $\$ 45$ million to $\$ 80$ million. The balance of plant costs is dominated by the generating plant cost, which is also estimated in Chapter 7 of the MIT study. The following is an excerpt from Chapter 7.

- It is possible to generate roughly $6,000 \mathrm{MW}$ of electricity from fluids that are currently being coproduced from oil and gas operations in the United States by using standard binary-cycle technology.

- Power plant capital costs for coproduced fluids range from about $\$ 1,500-2,300 / \mathrm{kW}$, depending on the temperature of the coproduced fluids.

- If a mass flow rate of $20 \mathrm{~kg} / \mathrm{s}$ can be sustained from a $200^{\circ} \mathrm{C}$ EGS reservoir, approximately $1 \mathrm{MW}$ of power can be produced; the same power can be achieved from a $250^{\circ} \mathrm{C}$ EGS reservoir, with only about $8.5 \mathrm{~kg} / \mathrm{s}$.

- Supercritical fluids from an EGS reservoir can be used in a triple-expansion power plant. About $15 \mathrm{~kg} / \mathrm{s}$ will yield about $10 \mathrm{MW}$ of power from fluids at $400^{\circ} \mathrm{C}$ and pressures in the range of 25-27 MPa; power plant thermal efficiencies will be about $31 \%$.

- Supercritical fluids from an EGS reservoir at very high pressures up to $35 \mathrm{MPa}$ and $400^{\circ} \mathrm{C}$ can be used in a single-expansion power plant to generate $10 \mathrm{MW}$ of power from flow rates of $21-30 \mathrm{~kg} / \mathrm{s}$, depending on the fluid pressure.

- Fluids derived from EGS reservoirs can be used in innovative cogeneration systems to provide electricity, heating, and cooling in conjunction with ground-source heat pumps. For example, the current MIT energy needs could be met with an EGS power plant with a 32 MW rating; this could be achieved with a flow rate of $1,760 \mathrm{~kg} / \mathrm{s}$ from a $200^{\circ} \mathrm{C}$ EGS reservoir using a single-flash system — or a $470 \mathrm{~kg} / \mathrm{s}$ flow rate from a $250^{\circ} \mathrm{C}$ EGS reservoir using a double-flash system - and backpressure turbines.

- The installed specific cost $(\$ / \mathrm{kW})$ for either a conventional 1- or 2-flash power plant at EGS reservoirs is inversely dependent on the fluid temperature and mass flow rate. Over the range from $150-340^{\circ} \mathrm{C}$ : For a mass flow rate of $100 \mathrm{~kg} / \mathrm{s}$, the specific cost varies from $\$ 1,894-1,773 / \mathrm{kW}$ (1-flash) and from $\$ 1,889-1,737 / \mathrm{kW}$ (2-flash); for a flow rate of $1,000 \mathrm{~kg} / \mathrm{s}$, the cost varies from $\$ 1,760-1,080 / \mathrm{kW}$ (1-flash) and from $\$ 1,718-981 / \mathrm{kW}$ (2-flash).

- The total plant cost, exclusive of wells, for a 2-flash plant receiving 1,000 kg/s from an EGS reservoir would vary from $\$ 50$ million to $\$ 260$ million, with a fluid temperature ranging from $150-340^{\circ} \mathrm{C}$; the corresponding power rating would vary from about 30-265 MW. If the reservoir were able to supply 
only $100 \mathrm{~kg} / \mathrm{s}$, the plant cost would vary from $\$ 5.6$ million to $\$ 45.8$ million over the same temperature range; the corresponding power rating would vary from 3-26.4 MW (MIT, 2008).

Hence, no single cost estimate in dollars per kilowatt is available for an EGS plant. Considering a $10 \mathrm{~km}$ depth, four wells, and $1,000 \mathrm{~kg} / \mathrm{s}$ flow rate, and 2-flash plant $(\$ 1300 / \mathrm{kW})$, at a $50 \mathrm{MW}$ rating the cost is about $\$ 145$ million or $\$ 2900 / \mathrm{kW}$. This certainly indicates that EGS may be cost competitive provided the technology does not encounter any stumbling blocks, such as one recently reported in the New York Times relating earthquakes to geothermal drilling. (http://www.nytimes.com/2009/12/12/ science/earth/12quake.html). However, given the present status of the geothermal demonstration projects in the Southeast, it is very unlikely that significant energy will be extracted from EGS sources prior to 2030 .

\subsection{CONCLUSIONS}

The United States has a total installed geothermal capacity of 3086.6 MW with 4584-7875 MW in development. Projects under development in the Southeast are located in Louisiana, Mississippi, and Texas. However, it is quite clear that no natural geothermal resources exist in the expanded southeastern states and that work on geopressured installations is just beginning. The potential for more advanced EGS projects that could provide a substantial amount of future energy resources requires further development; therefore, geothermal energy was not included as a viable renewable resource in the Southeast in this analysis.

\subsection{REFERENCES}

DOE. 2008. Geothermal Technologies Program. Geothermal Tomorrow (September 2008).

Jennejohn, D. 2010. US Geothermal Power Production and Development Update, Geothermal Energy Association, Washington, D.C., April, www.geo-energy.org

McKenna et al. 2005. Southern Methodist University, Oil and Gas Journal, September 5.

MIT. 2008. The Future of Geothermal Energy_Impact of Enhanced Geothermal Systems (EGS) on the United States in the 21st Century, January 2007, available at http://geothermal.inel.gov/publications/ future of geothermal energy.pdf.

Texas State Energy Conservation Office. 2008. Texas Renewable Energy Resource Assessment (December 2008). 



\section{SUMMARY AND CONCLUSIONS}

Studies that examine the potential for renewable energy resources in the southeastern United States (Alabama, Arkansas, Florida, Georgia, Kentucky, Louisiana, Mississippi, North Carolina, South Carolina, Tennessee, Virginia, and West Virginia) often reach diametrically opposite conclusions. Generally, since there has been comparatively little application of renewable energy resources in the Southeast, such results should be expected. This report on the barriers to and opportunities for the integration of renewable energy resources in the Southeast between now and the year 2030 provides some further insight into the question and concludes that renewable applications in the Southeast are physically possible but, as expected, are constrained by available resources, costs, environmental concerns, political will, and availability of capital resources. This review of existing literature regarding renewable resources in the Southeast includes a brief overview of wind, solar, biomass, hydro, and geothermal and offers a best estimate of the magnitude, time frame, and cost of deployment of these resources in the Southeast based upon the literature reviewed and reasonable engineering and economic estimates. Some aspects of the report (wind and geothermal) will also consider the extended Southeast by including Maryland, Missouri, Oklahoma, and Texas.

\subsection{MODELING AND INTEGRATION STUDIES}

Integration of renewable energy into the energy mix of the Southeast has multiple benefits. Among others it provides a more diverse resource base to meet electricity demand, reduces the amount of imported fuels into the region, and provides jobs within the local economies.

Renewable energy expansion adds to the mix of energy sources used to provide electricity with fuels that are clean and sustainable. The current mix of fuels is dominated by coal, with roughly $50 \%$ of all generation. Natural gas and nuclear power also provide significant fractions. Currently hydropower is the major source of renewable energy in the south with biomass expanding rapidly.

As indicated in Section 2, a number of studies have forecasted the potential contribution from various renewable energy sources. The models used all show different mixes, based on a combination of the input assumptions and the algorithms used in the model. Some only considered renewable portfolio standards, while others included carbon cap and trade. Within those policies, the studies may have defined the portfolio standard differently, emphasized different technologies included and to what, or whether energy efficiency qualifies as a resource. Similarly, there are a number of different cap -and-trade parameters that could be different between studies.

Clearly, the answers are not going to be identical, but the general trends are present in all the studies presented. However, the assumptions regarding the technical viability of each resource can alter the outcomes significantly. For example, failure of offshore wind to develop or geothermal having a major breakthrough will alter the picture significantly. Similarly, greenhouse gas emission requirements greatly alter the outcomes and generation types used. Finally, the constraint posed by the 2030 study limit could effectively exclude technologies that may be significant contributors to a renewable penetration at a later date. Two very good examples are enhanced geothermal and next-generation offshore wind using dc transmission at distances greater than 20 miles out.

\subsection{WIND}

Wind costs and environmental impacts are both low, and wind technology has reached a rather mature status. The main issues with wind nationally are with regard to grid reliability or stability at penetrations of $20 \%$ or higher. This issue does not seem to be present in the Southeast.

As shown in Table 3.1 of Sect. 3, without transmission access to the wind resources from the extended southeastern states (Missouri, Oklahoma, and Texas), the onshore potential for wind generation 
in the Southeast is clearly limited. This is primarily because only $0.23 \%$ of the land area is available for wind generation after exclusions. Even without exclusions, only a little over $1 \%$ of land area is viable.

On the other hand, offshore wind resources, as shown in Table 3.5 of Sect. 3, clearly establish the need for offshore wind in any Southeast renewable portfolio. By 2030, offshore wind alone using only ac cables could supply a nominal $100 \mathrm{GW}$ of capacity producing $350 \mathrm{TWhr}$ annually or $27.5 \%$ of 2009 generation in the southeastern states. Assuming that only $34 \%$ of the area beyond $3 \mathrm{~nm}$ is developed, the resource could ultimately provide $264 \mathrm{GW}$ of capacity and $923 \mathrm{TWhr}$ of energy annually.

Wind is essentially required for most renewable scenarios. To utilize wind, the Southeast must get significant wind resources, either from offshore wind or through sufficient transmission capacity to link wind resources in Missouri, Oklahoma, or Texas. If this is accomplished, achieving $20 \%$ renewable generation in the Southeast will be possible using the wind resource alone.

\subsection{SOLAR}

Solar insolation in the Southeast and extended Southeast is not as extensive or intense as in some states in the Southwest or California. As a result, the use of solar PV and solar thermal collectors will require larger arrays to provide the same total energy (kilowatt-hours) and capacity (kilowatts) in the Southeast. This increases total installed solar cost for PV by about $15 \%$, which tends to slow solar penetration in the Southeast.

Nevertheless, both solar PV and thermal collector systems are being installed in the Southeast, mainly in Florida. The total installed PV capacity is now estimated to be about $63.8 \mathrm{MW}_{\mathrm{DC}}$, with the vast majority of this in Florida (49.6 $\left.\mathrm{MW}_{\mathrm{DC}}, 46.15 \mathrm{MW}_{\mathrm{DC}}>100 \mathrm{MW}\right)$. Similarly for collector systems, the FPL hybrid plant provides $75 \mathrm{MW}$ of added thermal capacity.

However, as a result of the high cost of collectors and lower solar insolation in the Southeast, solar energy cannot be expected to provide a significant contribution to renewable capacity for at least another decade. Basically, a breakthrough to cost-effective non-silicon-based technology will be required.

\subsection{BIOMASS}

Use of biomass for energy is an attractive economic development opportunity. By substituting locally available resources for fuels imported from other regions of the United States and foreign countries, biomass communities can reduce "leakage" of financial resources, and therefore keep more money in the local economy. To indicate the potential benefits for economic development, the current economic impacts of using biomass fuels for industrial heat and electric power generation in the South were estimated in the SAFER study. Using an input-analysis model, economic contributions of biomass power and energy production in the South in 2007 were estimated and summarized in Tables 18 and 19 of the SAFER study. For all states in the region, total direct and indirect economic impacts included $\$ 7.3$ billion in output (revenues), $\$ 4.3$ billion in value added (personal and business income), and employment of over 110,000 workers (full time, part-time, seasonal). By industry sector, the agriculture and forestry sectors saw the greatest impacts, with over 60,000 jobs and $\$ 1.38$ billion in value added, representing the activities associated with biomass feedstock procurement.

Biomass will continue to contribute a significant portion to the total renewable energy available and utilized in the Southeast. The resource is available and the technology to utilize it exists and is being improved annually. If all biomass were used for electric generation, it is estimated that by the year 2020 biomass would contribute $97 \mathrm{GW}$ of capacity and $137 \mathrm{TWhr}$ of energy. These estimates use realistic conversion efficiency and annual capacity factors. 


\subsection{HYDRO}

Essentially all the hydro resources in the Southeast are conventional, being either run-of-river consisting of a conventional dam less than 10 feet high with limited storage or a storage type with a dam greater than 10 feet high and substantial storage capacity.

To go beyond the summary data presented in the INEL Potential Hydro report and present information about individual water energy resource sites and potential projects would be overly detailed for this reports analysis. Essentially the hydro generation in the Southeast can be increased by about a factor of 2 from $5618 \mathrm{MW}$ developed with $6161 \mathrm{MW}$ remaining potential to approximately 11,800 MW. This represents a nominal generation of $5100 \mathrm{GWhr}$. At least $80 \%$ of the remaining potential could be installed by 2030 without any technical breakthrough for a total of $10550 \mathrm{GW}$ producing $4620 \mathrm{GWhr}$ annually.

\subsection{GEOTHERMAL}

The United States currently leads the world's countries in online geothermal energy capacity and continues to be one of the principal countries to increase its geothermal growth (U.S. Geothermal Power Production And Development Update, April 2010). In 2007 geothermal energy accounted for 4\% of renewable energy-based electricity consumption in the United States (DOE, 2009). As of April 2010, geothermal electric power generation is occurring in nine U.S. states: Alaska, California, Hawaii, Idaho, Nevada, New Mexico, Oregon, Utah, and Wyoming. Other states, such as Colorado, Louisiana, Mississippi, and Texas, are soon to be added to the list. The United States has a total installed capacity of $3086.6 \mathrm{MW}$ with 4584-7875 MW in development.

Projects under development in the Southeast are located in Louisiana, Mississippi, and Texas. Louisiana currently hosts two known developing geothermal projects. One, a $0.05 \mathrm{MW}$ project, is a planned GHCP unit at a producing gas field. Another 5.25 MW project, which has been awarded $\$ 5$ million in ARRA funding from the DOE Geothermal Technologies Program, will develop geopressured resources at an oil and gas field and is in the advanced stages of development. Mississippi's first developing geothermal project is rated at $0.05 \mathrm{MW}$ and is a planned GHCP unit at a producing oil field. The first geothermal project being developed in Texas is a $0.4 \mathrm{MW}$ planned GHCP unit. In addition to this project, DOE awarded \$32.4 million of ARRA funding to 13 recipients in Texas for research in areas such as EGS R\&D and innovative exploration technologies.

Enhanced Geothermal Systems (EGS) commonly refers to any resource that requires artificial stimulation and includes resources that have to be fully engineered, or ones that produce hydrothermal fluid, but sub-commercially. In certain respects EGS is still a young and not fully proven technology. However, GTP recently provided $\$ 73.5$ million in federal funding to EGS demonstration projects in five different states. In addition to funding provided by DOE, the total industry cost share for these projects is $\$ 99.1$ million.

It is well known that no natural geothermal resources exist in the expanded southeastern states and that work on geo-pressured installations is just beginning. Moreover, the potential for development of more advanced EGS projects that could provide a substantial amount of future energy resources requires further development. Because of the uncertainty in the recovery factor from EGS, the values may range from 0.01 to 2 times larger; more experience is needed with the EGS resource. This uncertainty plus possible shorter lifetime ( $<30$ years) may make EGS resources a very risky venture for the foreseeable future. Therefore EGS are not included as a viable renewable resource in the Southeast in this analysis. If successful demonstrations and development does occur, EGS could become a breakthrough technology, which together with offshore wind would greatly expand the renewable base in the Southeast (or extended Southeast). 


\subsection{REFERENCES}

DOE. 2011. Electric Power Annual, DOE/EIA-0348(2009), Office of Electricity, Renewables, and Uranium Statistics, Washington, D.C., http://www.eia.gov/cneaf/electricity/epa/epa_sum.html Jennejohn, D. April 2010. US Geothermal Power Production and Development Update, Geothermal Energy Association, Washington, D.C., www.geo-energy.org 
APPENDIX A.

ONSHORE AND OFFSHORE WIND POWER POTENTIAL 



\section{APPENDIX A. ONSHORE AND OFFSHORE WIND POWER POTENTIAL}

Wind resource maps for both onshore and offshore are only included in this appendix for reference. For maps with better resolution, the reader is referred to the original resources at (http://www.windpoweringamerica.gov).

For the offshore wind potential, NREL has produced estimates of the gross (not reduced by environmental or human use considerations) potential expressed in "installed capacity." This is the potential megawatts of rated capacity that could be installed at offshore areas with mean annual wind speeds of $7.0 \mathrm{~m} / \mathrm{sec}$ and greater at $90 \mathrm{~m}$ height, assuming $5 \mathrm{MW}$ of installed capacity per square kilometer of water. The offshore wind potential tables present the resource broken down by annual wind speed, water depth, and distance from shore. The summary table is provided below.

Note that for the extended southeastern states with significant offshore wind potential (Georgia, Maryland, North Carolina, South Carolina, Virginia, Louisiana, and Texas), the total offshore potential for wind speed greater than $7 \mathrm{~m} / \mathrm{sec}$ at $90 \mathrm{~m}$ height is nominally $1230 \mathrm{GW}$ (Table A.1). Excluding Louisiana and Texas, the total potential is still $898 \mathrm{GW}$. Assuming that $25 \%$ can be developed with a capacity factor of $40 \%$, this yields $225 \mathrm{GW}$ of capacity and $787 \mathrm{TWhr} /$ year of generated electric energy. According to EIA data (2009), the nominal U.S. capacity from all generation sources is about $1100 \mathrm{GW}$, which generated $3950 \mathrm{TWhr} / \mathrm{yr}$. Hence, offshore wind potential in the Southeast is nominally $20 \%$ of present installed national capacity that could nominally generate (at $40 \%$ capacity factor) about

Table A.1. Offshore wind resource by state and wind speed internal within $50 \mathrm{~nm}$ of shore

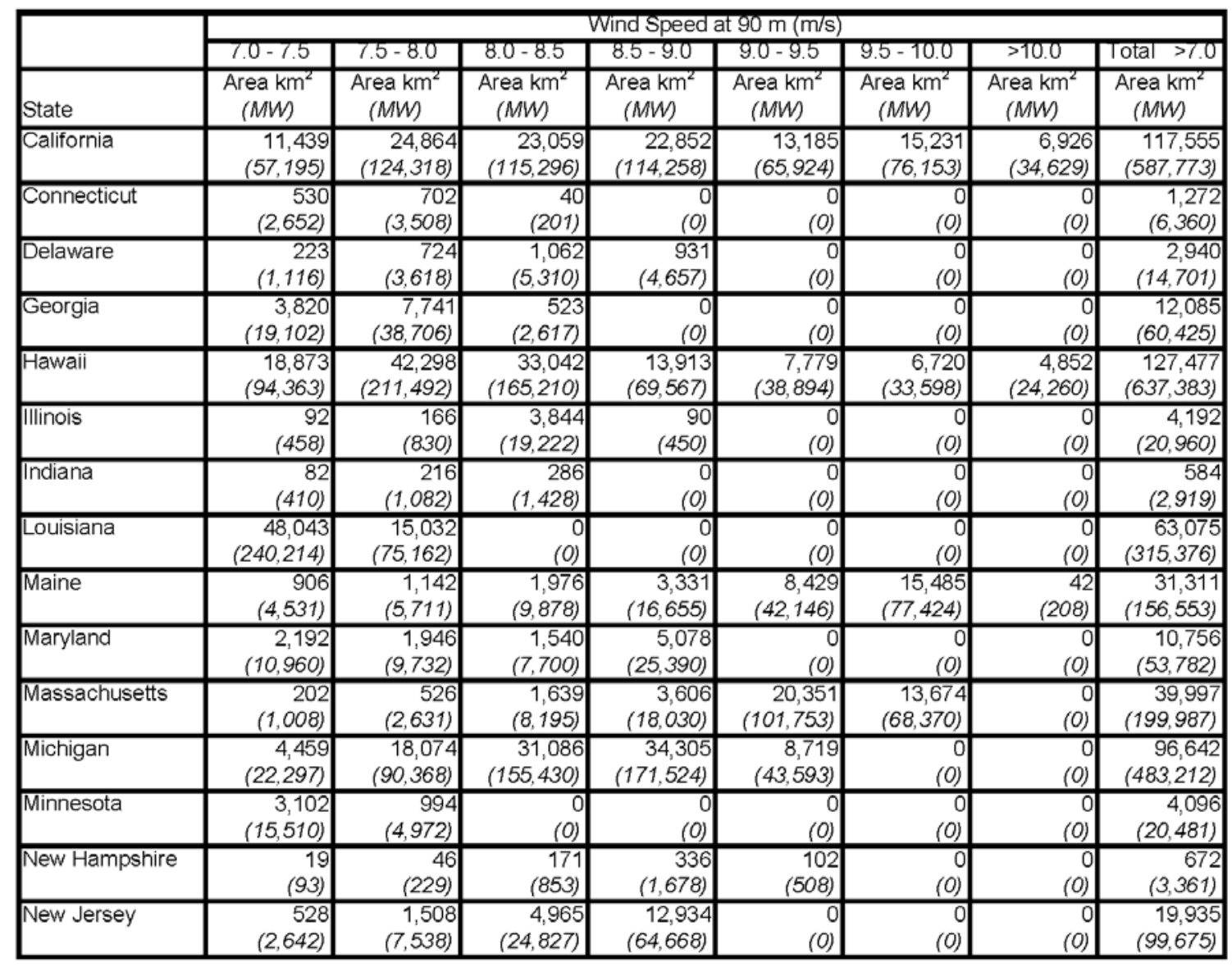


Table A.1. (continued)

\begin{tabular}{|c|c|c|c|c|c|c|c|c|}
\hline & \multicolumn{8}{|c|}{ Wind speed at $90 \mathrm{~m}(\mathrm{~m} / \mathrm{s})$} \\
\hline & $7.0-7.5$ & $7.5-8.0$ & $8.0-8.5$ & $8.5-9.0$ & $9.0-9.5$ & $9.5-100$ & $>10.0$ & Total $>7.0$ \\
\hline State & $\begin{array}{c}\text { Area km² } \\
(M W)\end{array}$ & $\begin{array}{c}\text { Area km² } \\
(M W)\end{array}$ & $\begin{array}{c}\text { Area km² } \\
(M W)\end{array}$ & $\begin{array}{c}\text { Area km² } \\
(M W)\end{array}$ & $\begin{array}{c}\text { Area km² } \\
(M W)\end{array}$ & $\begin{array}{c}\text { Area km² } \\
(M W)\end{array}$ & $\begin{array}{c}\text { Area km² } \\
(M W)\end{array}$ & $\begin{array}{c}\text { Area km² } \\
(M W)\end{array}$ \\
\hline New York & $\begin{array}{r}1,105 \\
(5,524)\end{array}$ & $\begin{array}{r}4,358 \\
(21,789) \\
\end{array}$ & $\begin{array}{r}8,324 \\
(41,621) \\
\end{array}$ & $\begin{array}{r}2,876 \\
(14,382)\end{array}$ & $\begin{array}{r}7,453 \\
(37,267) \\
\end{array}$ & $\begin{array}{r}5,322 \\
(26,612) \\
\end{array}$ & $\begin{array}{r}0 \\
(0)\end{array}$ & $\begin{array}{r}29,439 \\
(147,194)\end{array}$ \\
\hline North Carolina & $\begin{array}{r}1,847 \\
(9,237)\end{array}$ & $\begin{array}{r}4,098 \\
(20,491)\end{array}$ & $\begin{array}{r}13,655 \\
(68,274)\end{array}$ & $\begin{array}{r}39,875 \\
(199,374)\end{array}$ & $\begin{array}{r}16 \\
(80)\end{array}$ & $\begin{array}{r}0 \\
(0)\end{array}$ & $\begin{array}{r}0 \\
(0)\end{array}$ & $\begin{array}{r}59,491 \\
(297,456)\end{array}$ \\
\hline Ohio & $\begin{array}{r}341 \\
(1,705)\end{array}$ & $\begin{array}{r}3,067 \\
(15,333)\end{array}$ & $\begin{array}{r}5,829 \\
(29,147)\end{array}$ & $\begin{array}{r}0 \\
\text { (0) }\end{array}$ & $\begin{array}{r}0 \\
(0)\end{array}$ & $\begin{array}{r}0 \\
\text { (0) }\end{array}$ & $\begin{array}{r}0 \\
(0)\end{array}$ & $\begin{array}{r}9,237 \\
(46,186) \\
\end{array}$ \\
\hline Oregon & $\begin{array}{r}388 \\
(1,938)\end{array}$ & $\begin{array}{r}1,493 \\
(7,465)\end{array}$ & $\begin{array}{r}8,644 \\
(43,222)\end{array}$ & $\begin{array}{r}13,925 \\
(69,623)\end{array}$ & $\begin{array}{r}7,394 \\
(36,969)\end{array}$ & $\begin{array}{r}6,065 \\
(30,327)\end{array}$ & $\begin{array}{r}5,986 \\
(29,928)\end{array}$ & $\begin{array}{r}43,894 \\
(219,471)\end{array}$ \\
\hline Pennsylvania & $\begin{array}{r}34 \\
(171)\end{array}$ & $\begin{array}{r}211 \\
(1,054)\end{array}$ & $\begin{array}{r}1,679 \\
(8,395)\end{array}$ & $\begin{array}{r}0 \\
(0)\end{array}$ & $\begin{array}{r}0 \\
\text { (0) }\end{array}$ & $\begin{array}{r}0 \\
\text { (0) }\end{array}$ & $\begin{array}{r}0 \\
(0)\end{array}$ & $\begin{array}{r}1,924 \\
(9,620)\end{array}$ \\
\hline Rhode Island & $\begin{array}{r}224 \\
(1,121)\end{array}$ & $\begin{array}{r}126 \\
(630)\end{array}$ & $\begin{array}{r}283 \\
(1,417)\end{array}$ & $\begin{array}{r}671 \\
(3,356)\end{array}$ & $\begin{array}{r}1,461 \\
(7,307)\end{array}$ & $\begin{array}{r}2,360 \\
(11,799)\end{array}$ & $\begin{array}{r}0 \\
\text { (0) }\end{array}$ & $\begin{array}{r}5,126 \\
(25,631)\end{array}$ \\
\hline South Carolina & $\begin{array}{r}1,457 \\
(7,283)\end{array}$ & $\begin{array}{r}8,202 \\
(41,010)\end{array}$ & $\begin{array}{r}10,384 \\
(51,919)\end{array}$ & $\begin{array}{r}6,007 \\
(30,033)\end{array}$ & $\begin{array}{r}0 \\
(0)\end{array}$ & $\begin{array}{r}0 \\
(0)\end{array}$ & $\begin{array}{r}0 \\
(0)\end{array}$ & $\begin{array}{r}26,049 \\
(130,244)\end{array}$ \\
\hline $\operatorname{Texas}^{1}$ & $\begin{array}{r}2,019 \\
(10,095) \\
\end{array}$ & $\begin{array}{r}24,823 \\
(124,114) \\
\end{array}$ & $\begin{array}{r}16,556 \\
(82,782) \\
\end{array}$ & $\begin{array}{r}12,273 \\
(61,363) \\
\end{array}$ & $\begin{array}{r}0 \\
(0) \\
\end{array}$ & $\begin{array}{r}0 \\
(0) \\
\end{array}$ & $\begin{array}{r}0 \\
(0) \\
\end{array}$ & $\begin{array}{r}55,671 \\
(278,353) \\
\end{array}$ \\
\hline Virginia & $\begin{array}{r}889 \\
(4,446)\end{array}$ & $\begin{array}{r}3,658 \\
(18,289)\end{array}$ & $\begin{array}{r}6,549 \\
(32,743)\end{array}$ & $\begin{array}{r}7,794 \\
(38,970)\end{array}$ & (0) & $\begin{array}{r}0 \\
\text { (0) }\end{array}$ & $\begin{array}{r}0 \\
\text { (0) }\end{array}$ & $\begin{array}{r}18,890 \\
(94,448)\end{array}$ \\
\hline Washington & $\begin{array}{r}1,573 \\
(7,863)\end{array}$ & $\begin{array}{r}4,621 \\
(23,107)\end{array}$ & $\begin{array}{r}18,261 \\
(91,304)\end{array}$ & $\begin{array}{r}0 \\
(0)\end{array}$ & $\begin{array}{r}0 \\
(0)\end{array}$ & $\begin{array}{r}0 \\
(0)\end{array}$ & $\begin{array}{r}0 \\
(0)\end{array}$ & $\begin{array}{r}24,455 \\
(122,274)\end{array}$ \\
\hline Wisconsin & $\begin{array}{r}3,715 \\
(18,577)\end{array}$ & $\begin{array}{r}3,405 \\
(17,023)\end{array}$ & $\begin{array}{r}7,761 \\
(38,806)\end{array}$ & $\begin{array}{r}8,417 \\
(42,087)\end{array}$ & $\begin{array}{r}0 \\
\text { (0) }\end{array}$ & $\begin{array}{r}0 \\
\text { (0) }\end{array}$ & $\begin{array}{r}0 \\
(0)\end{array}$ & $\begin{array}{r}23,298 \\
(116,492)\end{array}$ \\
\hline Total & $\begin{array}{r}108,102 \\
(540,510)\end{array}$ & $\begin{array}{r}174,040 \\
(870,202)\end{array}$ & $\begin{array}{r}201,159 \\
(1,005,795)\end{array}$ & $\begin{array}{r}189,213 \\
(946,063)\end{array}$ & $\begin{array}{r}74,888 \\
(374,441) \\
\end{array}$ & $\begin{array}{r}64,856 \\
(324,282) \\
\end{array}$ & $\begin{array}{r}17,805 \\
(89,024)\end{array}$ & $\begin{array}{r}830,064 \\
(4,150,319)\end{array}$ \\
\hline
\end{tabular}

$20 \%$ of the nation's electrical energy. Nationally if $25 \%$ of all offshore capacity were developed, this would add $1038 \mathrm{GW}$ and $3600 \mathrm{TWhr} /$ year of generation, which is essentially the present U.S. electric systems capability. However, this brief analysis does not provide any logical support for the $25 \%$ argument, and as discussed in Sect. 3, the values could be much higher provided a viable undersea dc transmission system is developed in parallel with the buildout.

\section{A.1 WIND RESOURCE MAPS FOR ONSHORE AND OFFSHORE BY STATE}

Alabama has limited wind resource potential both onshore and offshore.

Arkansas has wind resources that can be considered for utility-scale production. The highest wind resources are found on exposed ridge crests and elevated terrain areas in the western part of the state. The best wind resource areas are concentrated on the higher elevations of the Ouachita Mountains, particularly near Mena, and the Boston Mountains of northwestern Arkansas.

For Arkansas (and each other state), the NREL published a factsheet on economic benefits, carbon dioxide $\left(\mathrm{CO}_{2}\right)$ emissions reductions, and water conservation benefits from 1,000 MW of new wind power. Projected direct economic impacts for Arkansas include 1,924 new jobs with $\$ 188.5$ million to local economies during the construction phase and 268 new long-term jobs with $\$ 21.2$ million per year to local economies (NREL, 2008). In addition, projected indirect and induced economic impacts include 1,572 new jobs during the construction phase and 236 local jobs during the operational phase. See http://www.windpoweringamerica.gov/pdfs/economic_development/2008/ar_wind_benefits_factsheet.pdf 


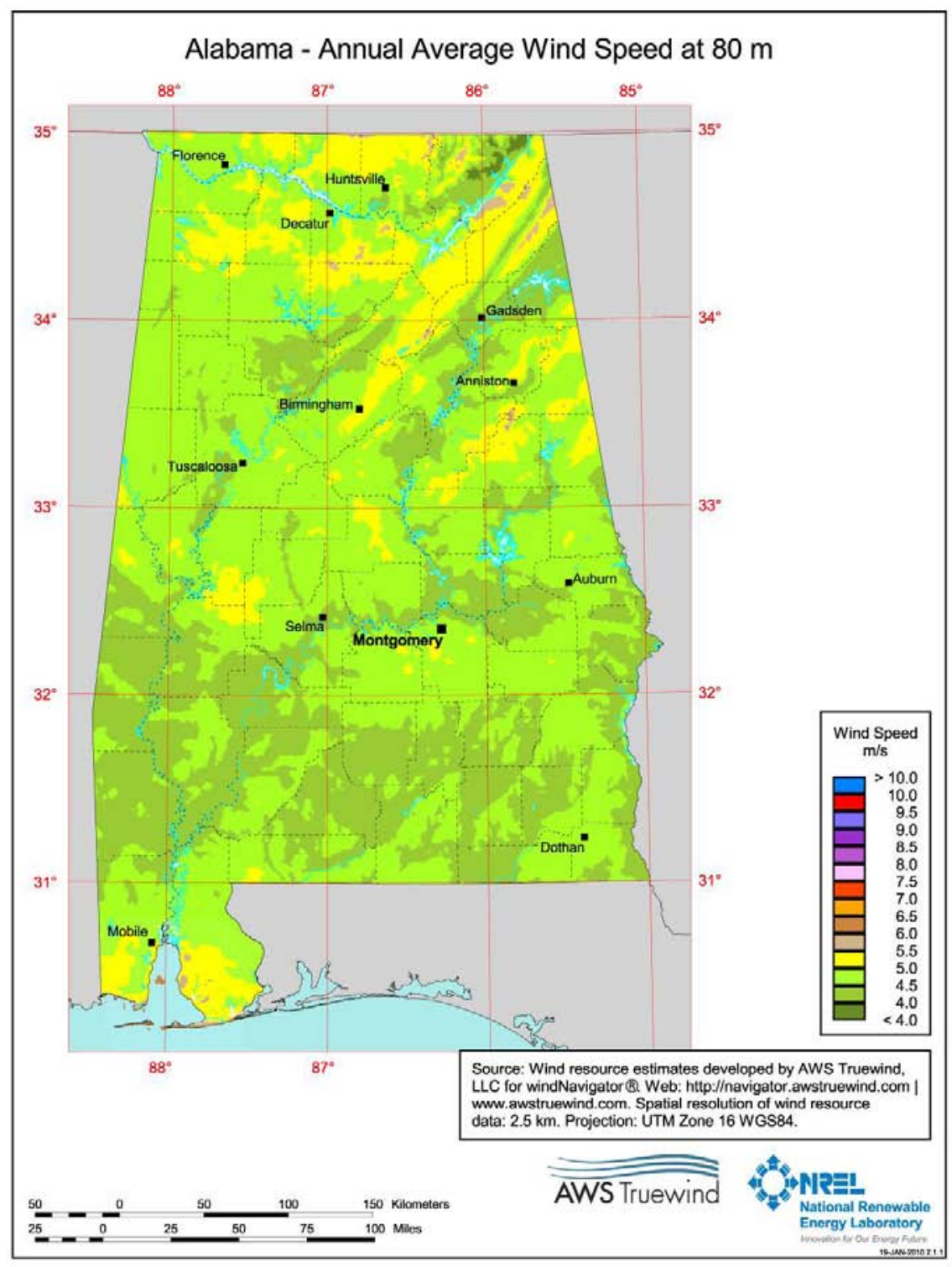

Fig. A.1. Alabama annual average wind speed at $80 \mathrm{~m}$. (Source: National Renewable Energy Laboratory, 2010) http://www.windpoweringamerica.gov/ images/windmaps/al_80m.jpg 


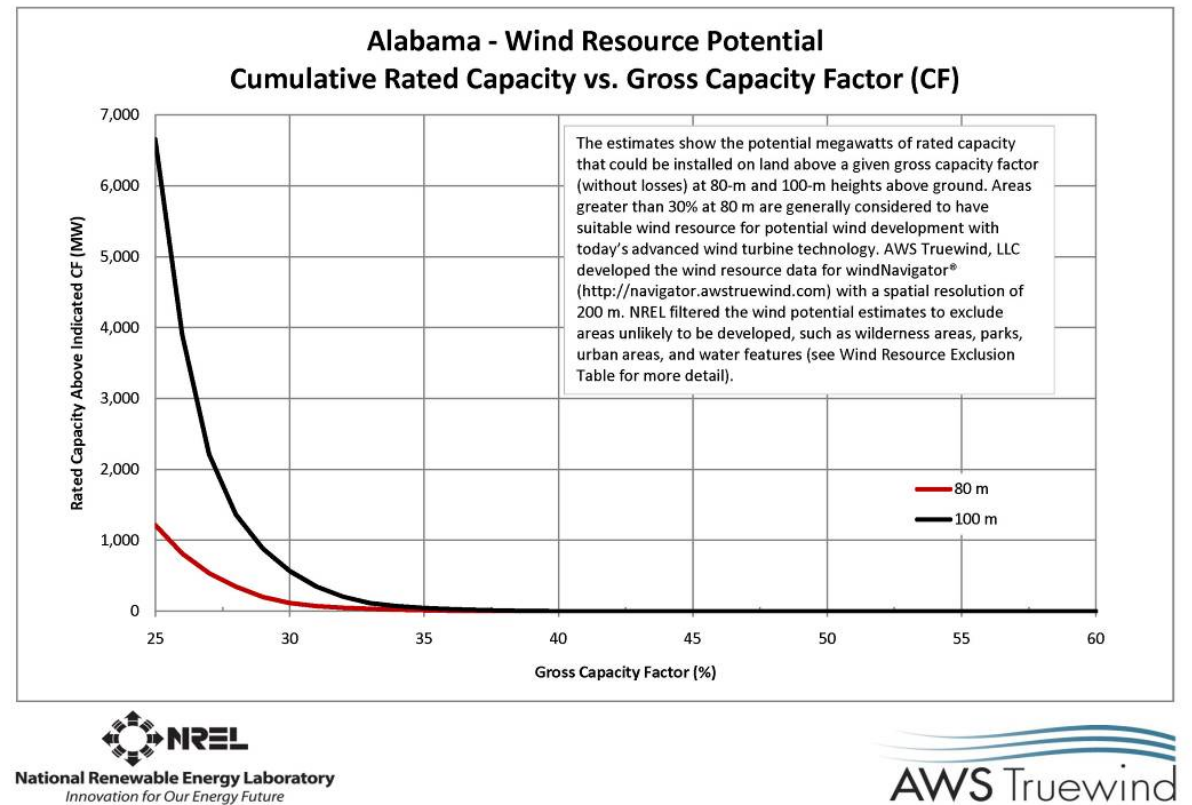

Fig. A.2. Alabama wind resource potential: Cumulative rated capacity vs gross capacity factor (CF). (Source: NREL, 2010) http://www.windpoweringamerica.gov/images/ windmaps/al_wind_potential_chart.jpg

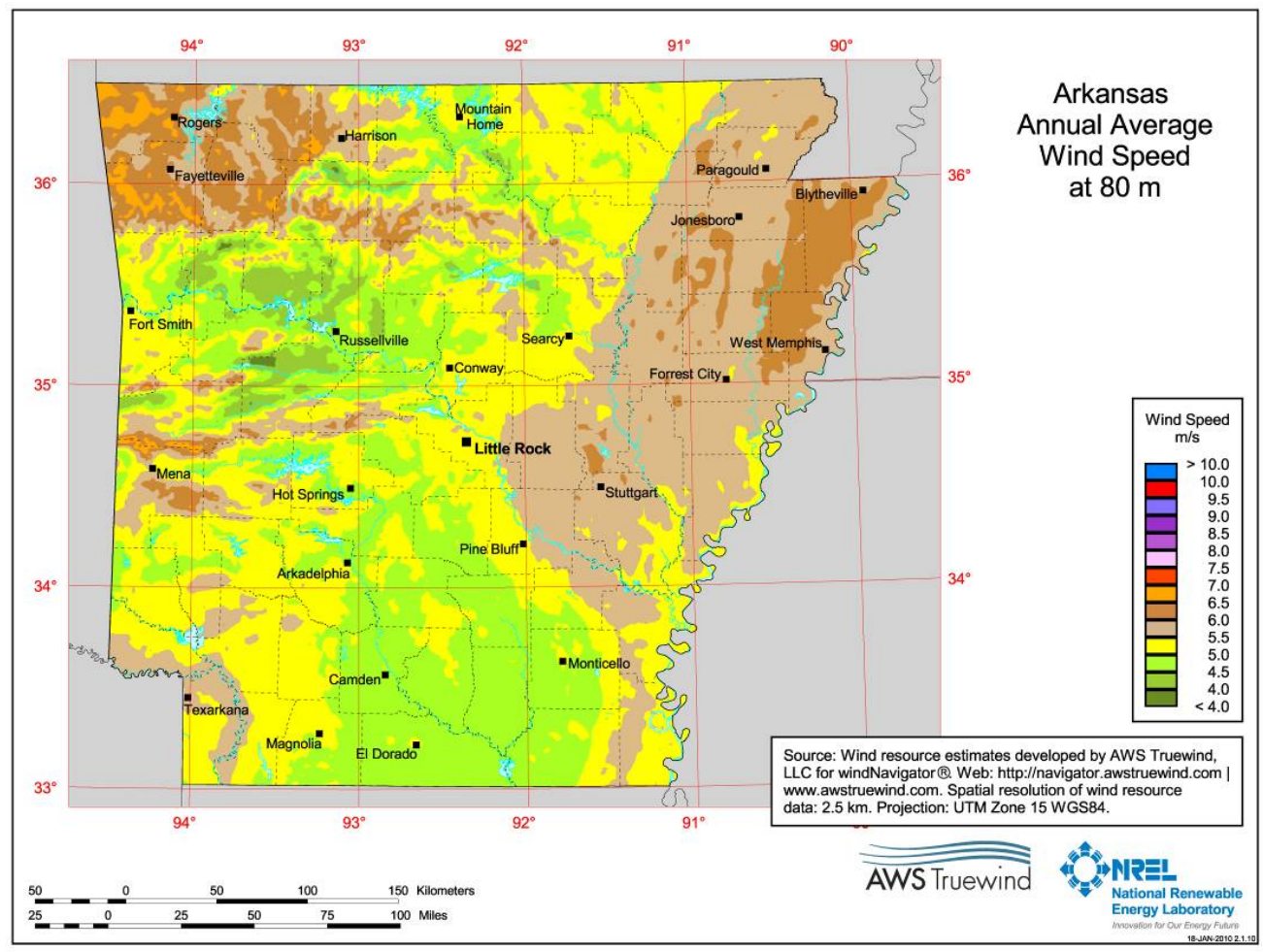

Fig. A.3. Arkansas annual average wind speed at 80-meter. (Source: National Renewable Energy Laboratory, 2010) http://www.windpoweringamerica.gov/ images/windmaps/ar_80m.jpg 


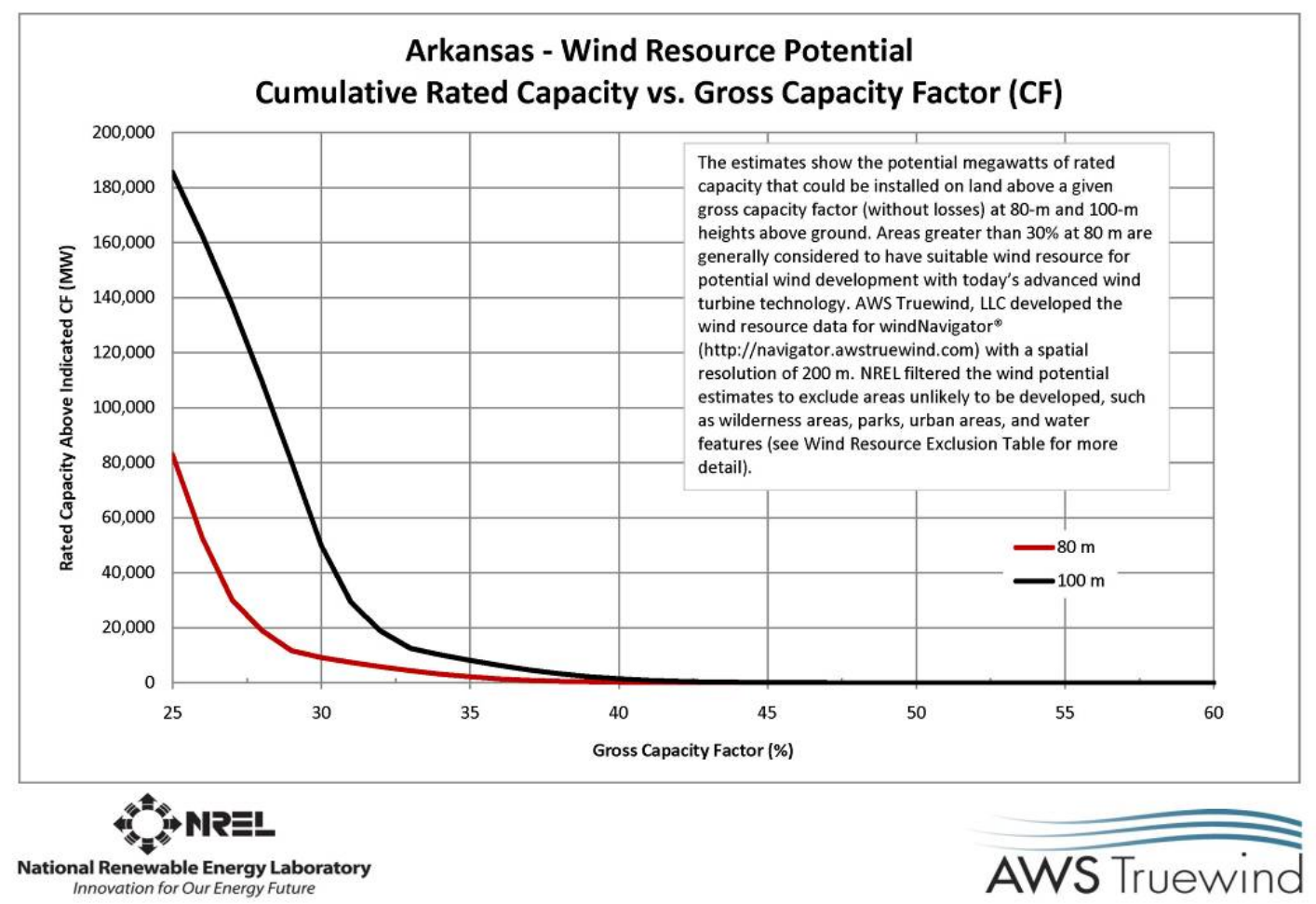

Fig. A.4. Arkansas wind resource potential: Cumulative rated capacity vs gross capacity factor (CF). (Source: NREL, 2010) http://www.windpoweringamerica.gov/images/windmaps/ ar_wind_potential_chart.jpg

Florida has poor wind power on the land and only marginal offshore.

Georgia has wind resources consistent with utility-scale production. The good-to-excellent resource areas are located on ridge crests in extreme northern Georgia. Other good resource areas are found on exposed capes along the Atlantic Coast.

For Georgia, the NREL published a factsheet on economic benefits, $\mathrm{CO}_{2}$ emissions reductions, and water conservation benefits from 1,000 MW of new wind power. Projected direct economic impacts for Georgia include 908 new jobs with \$244 million to local economies during the construction phase and 60 new long-term jobs with $\$ 3.5$ million per year to local economies (NREL, 2008). In addition, projected indirect and induced economic impacts include 2,609 new jobs during the construction phase and 587 local jobs during the operational phase (NREL, 2008).

Kentucky has limited wind power potential. The highest wind resources on the ridge crests in the southeastern corner of the state, which are concentrated in the Black Mountain region near the Virginia border.

Louisiana has limited wind power potential on the land and marginal offshore.

Mississippi has limited wind power on the land and marginal offshore.

Missouri has wind resources consistent with utility-scale production. The good-to-excellent resource areas are located in the northwest corner of the state and along the Oklahoma border. 


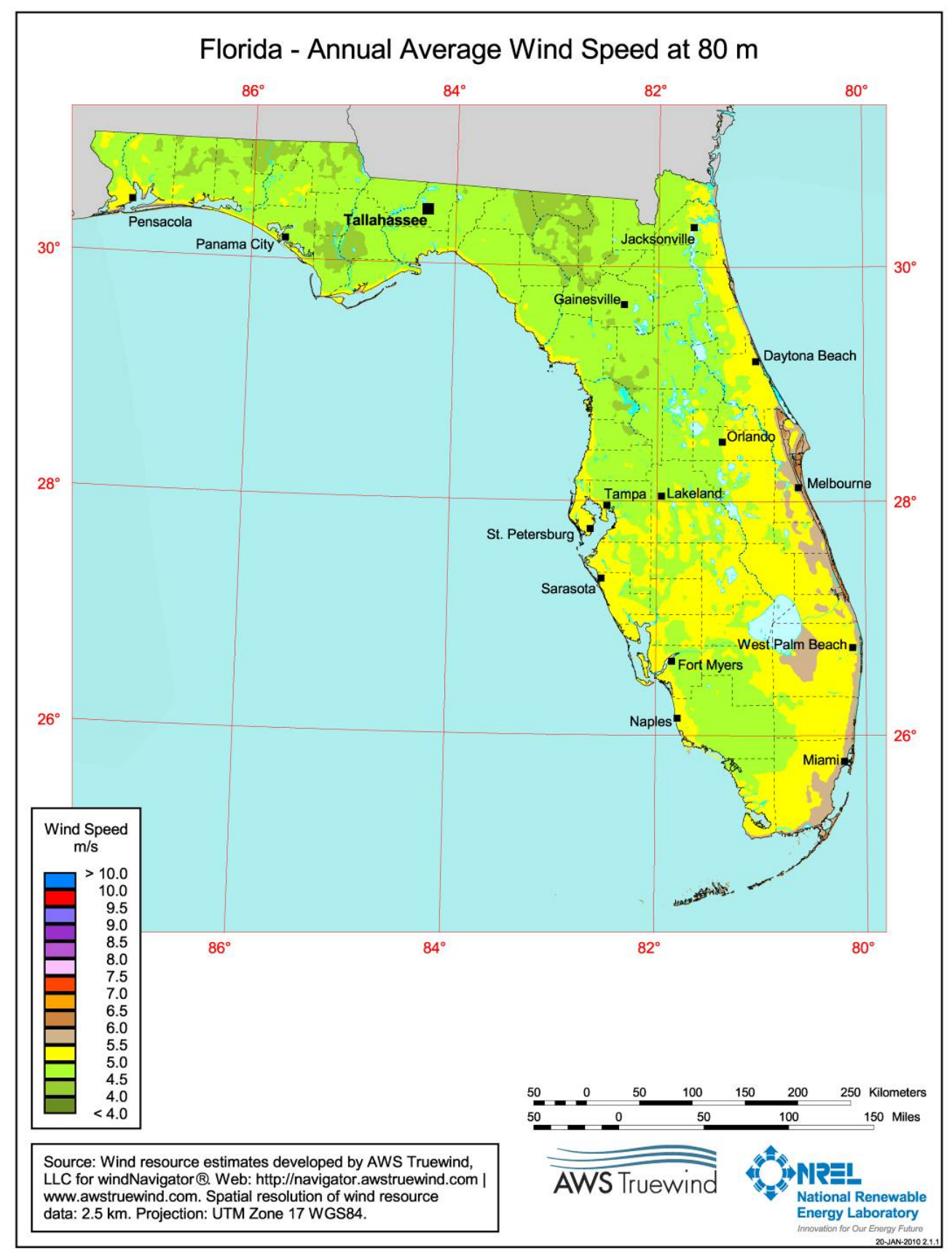

Fig. A.5. Florida annual average wind speed at 80 m. (Source: NREL, 2010) http://www.windpoweringamerica.gov/images/windmaps/fl_80m.jpg 


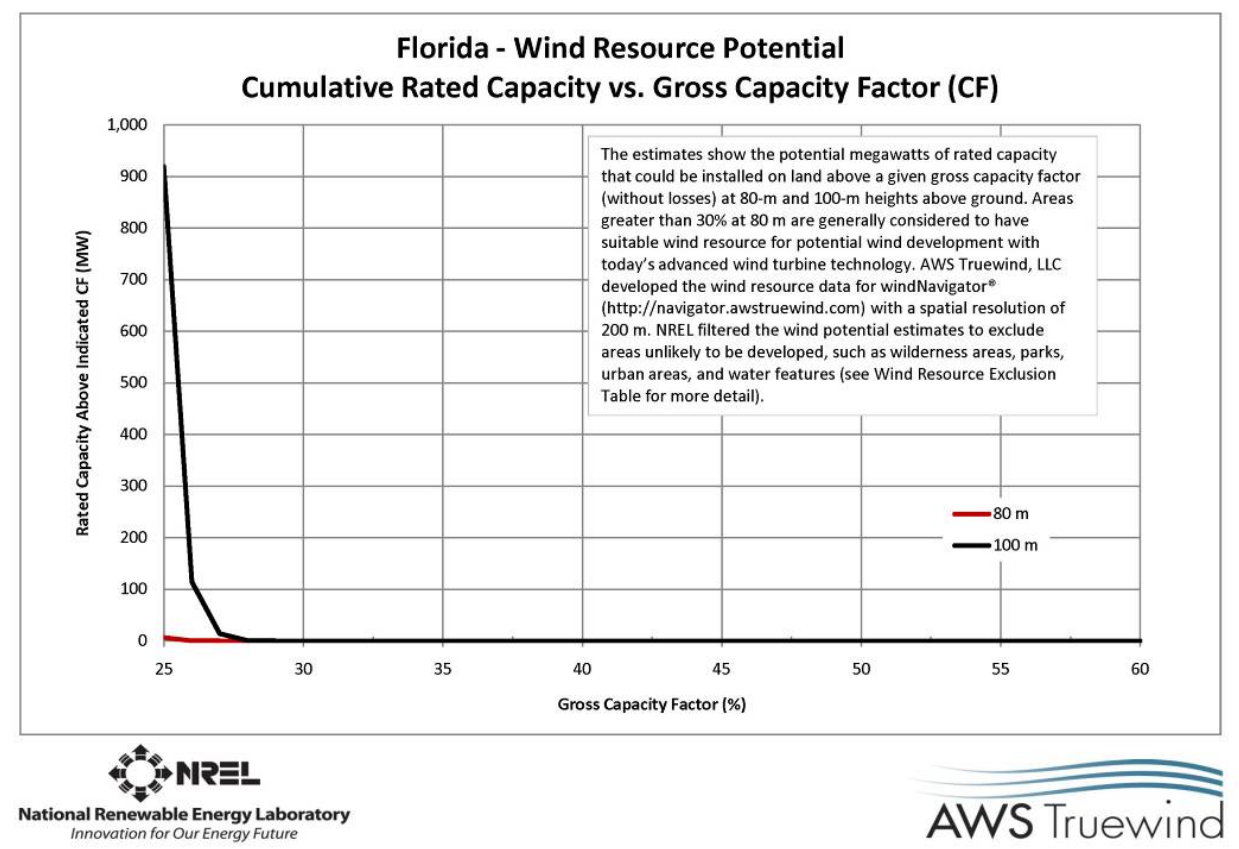

Fig. A.6. Florida wind resource potential: cumulative rated capacity vs gross capacity factor (CF). (Source: NREL, 2010) http://www.windpoweringamerica.gov/ images/windmaps/fl_wind_potential_chart.jpg 


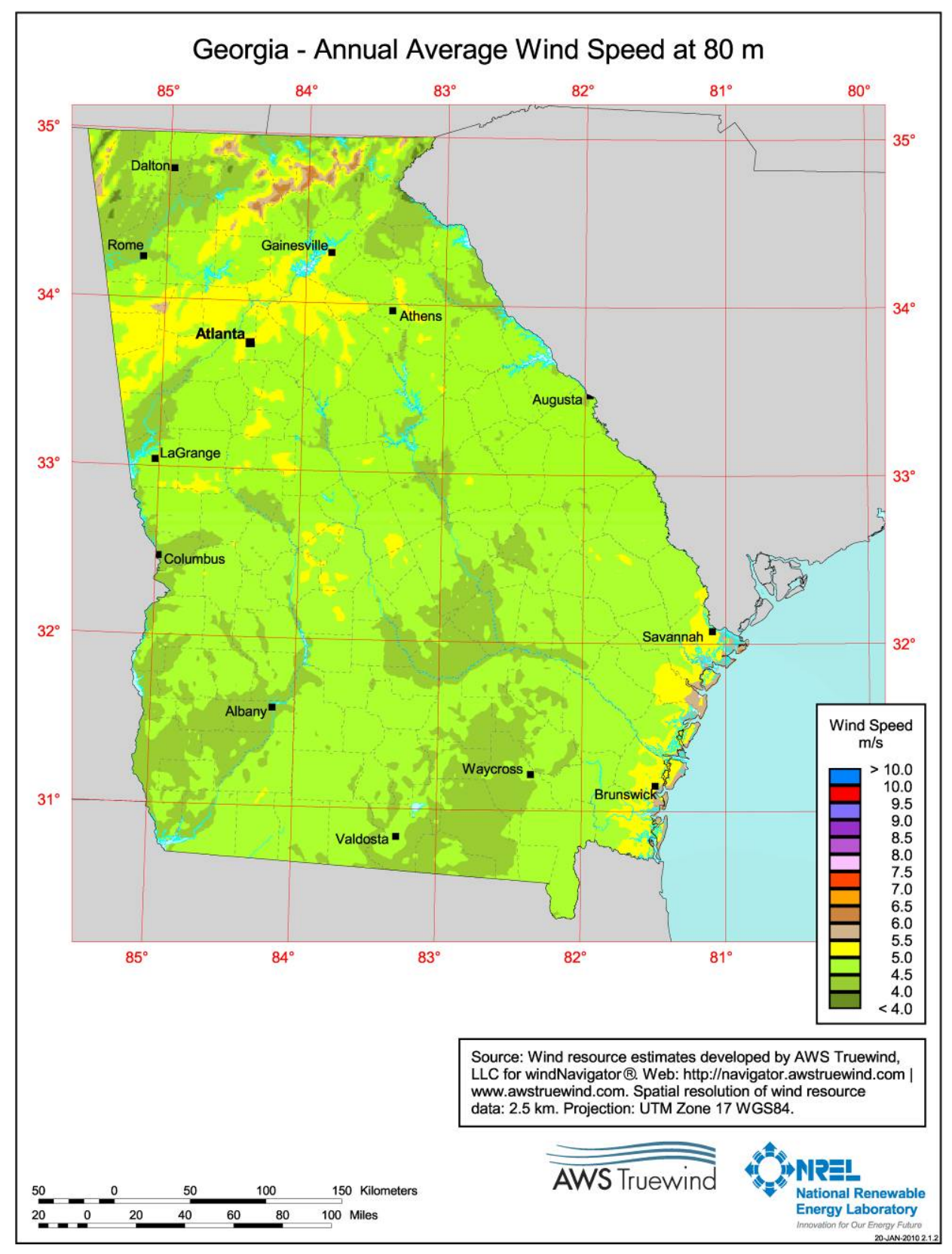

Fig. A.7. Georgia annual average wind speed at $80 \mathrm{~m}$. (Source: National Renewable Energy Laboratory, 2010) http://www.windpoweringamerica.gov/images/ windmaps/ga_80m.jpg 


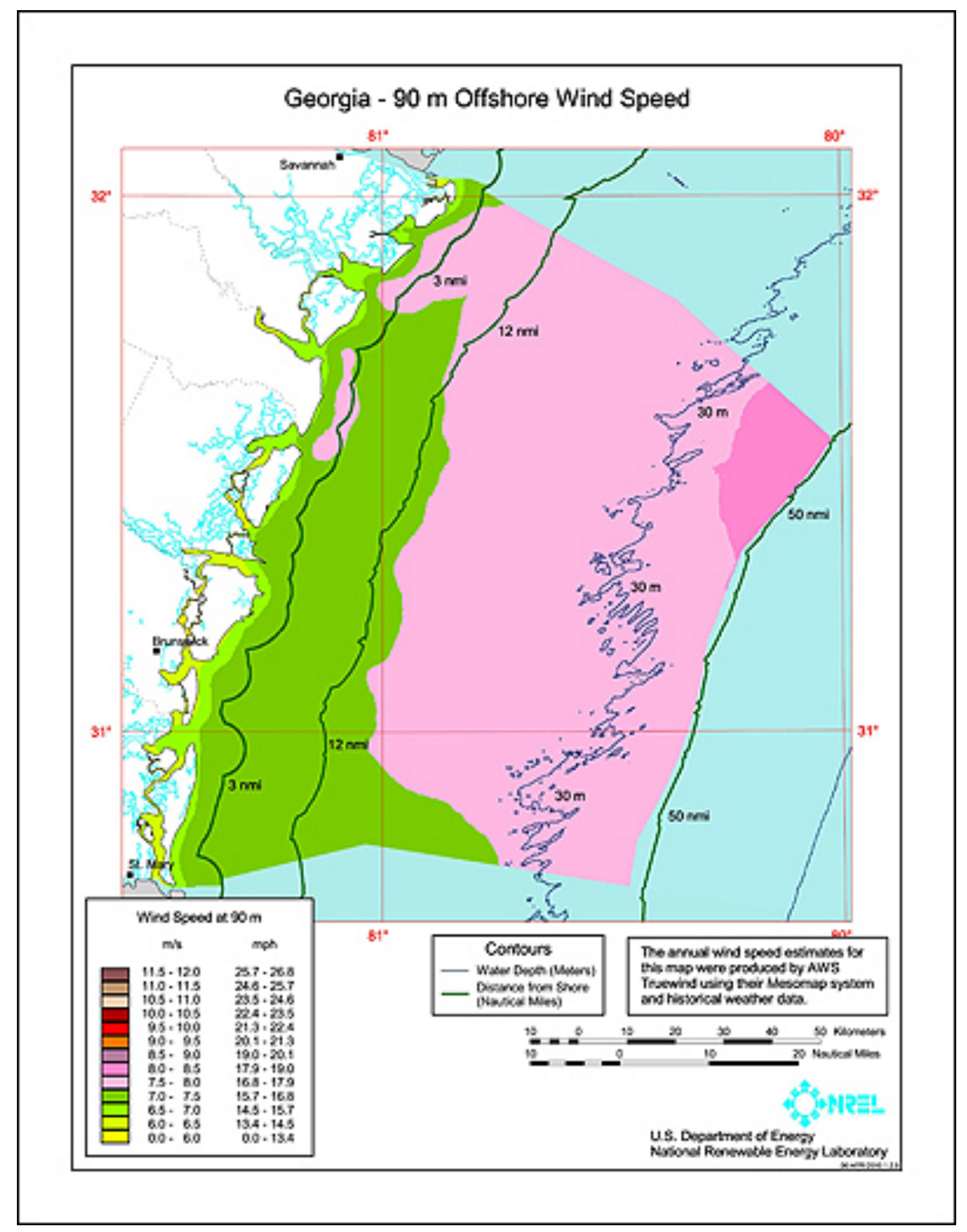

Fig. A.8. Wind resource of Georgia offshore mean annual wind speed at $90 \mathrm{~m}$. (http://www.gawwg.org/Offshore90MSpeed.pdf) 

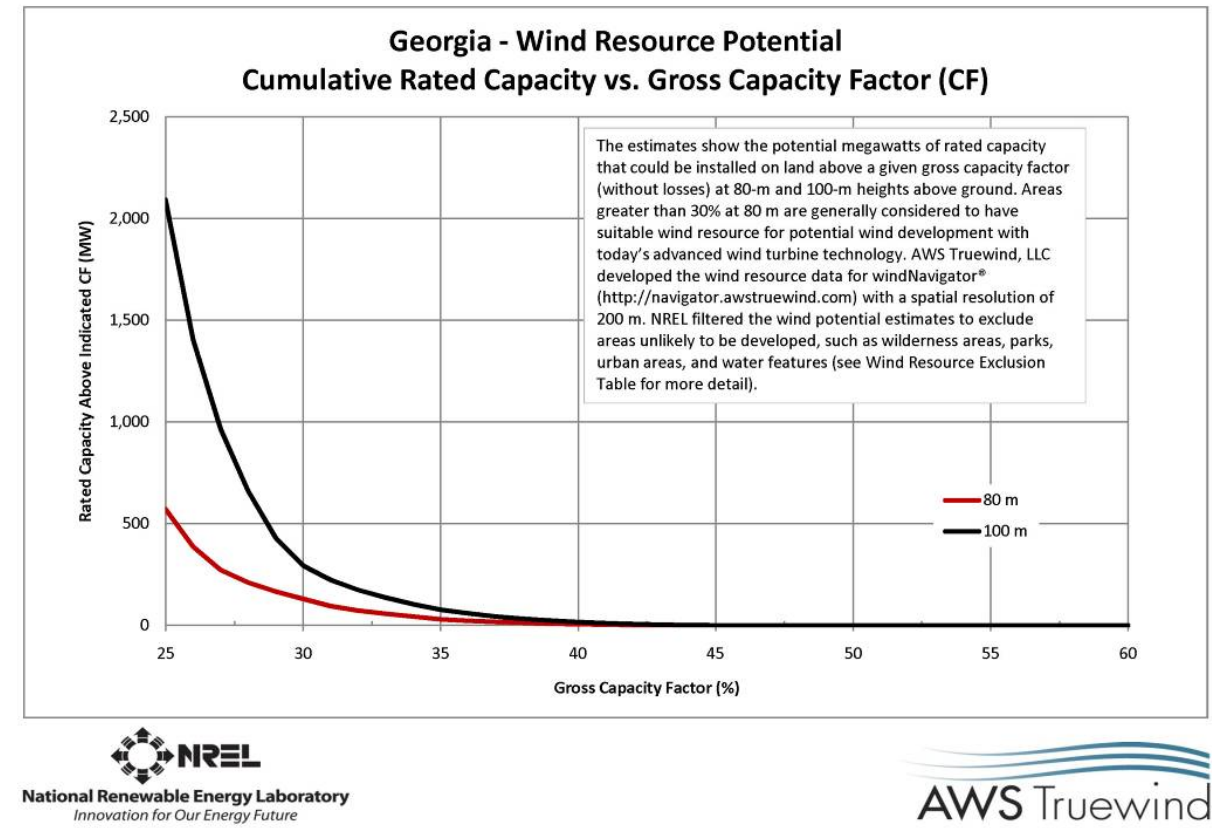

AWS Truewind

Fig. A.9. Georgia wind resource potential: Cumulative rated capacity vs gross capacity factor (CF). (Source: NREL, 2010) http://www.windpoweringamerica.gov/ images/windmaps/ga_wind_potential_chart.jpg

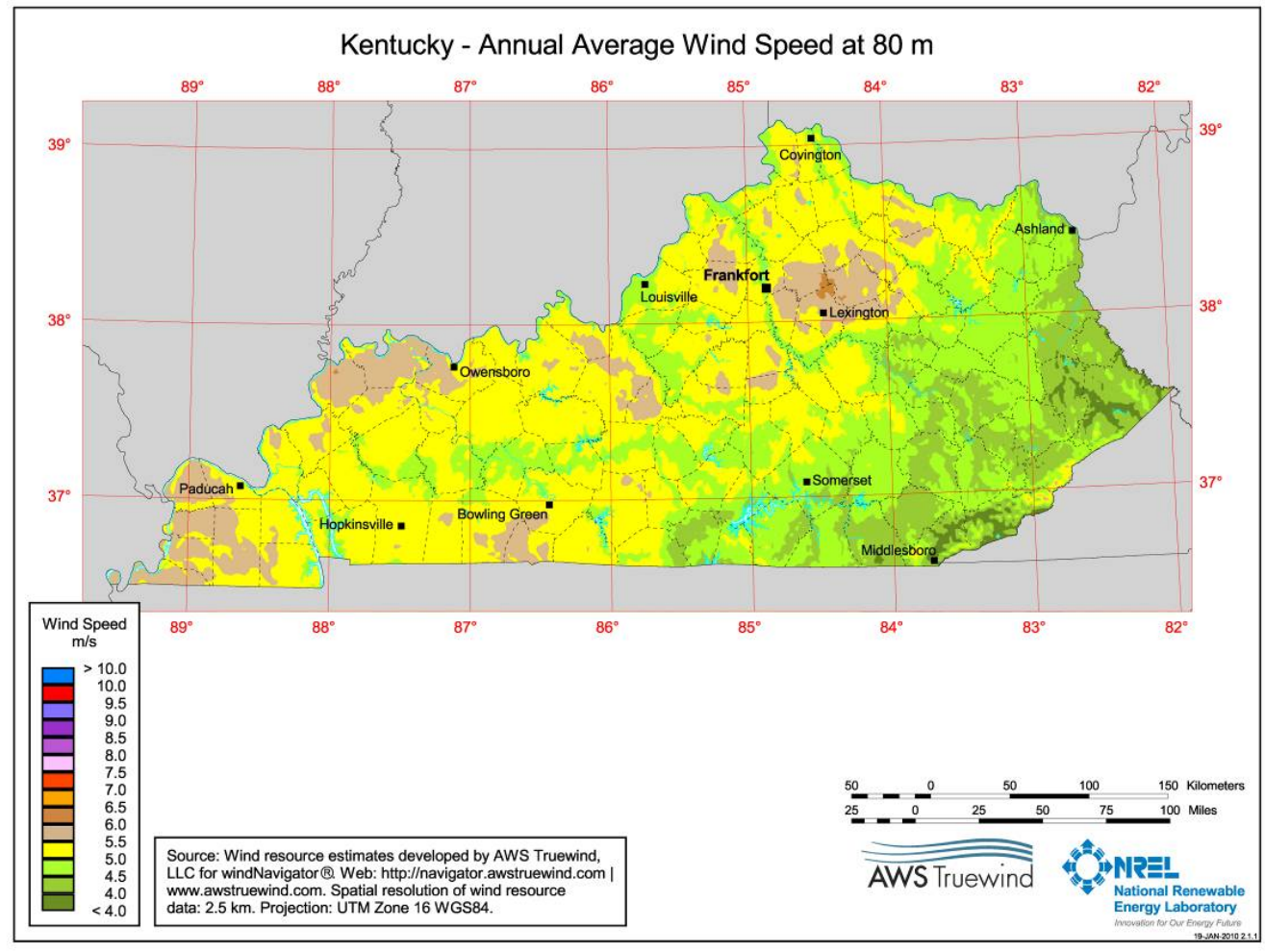

Fig. A.10. Kentucky annual average wind speed at $80 \mathrm{~m}$. (Source: National Renewable Energy Laboratory, 2010) http://www.windpoweringamerica.gov/ images/windmaps/ky_80m.jpg 


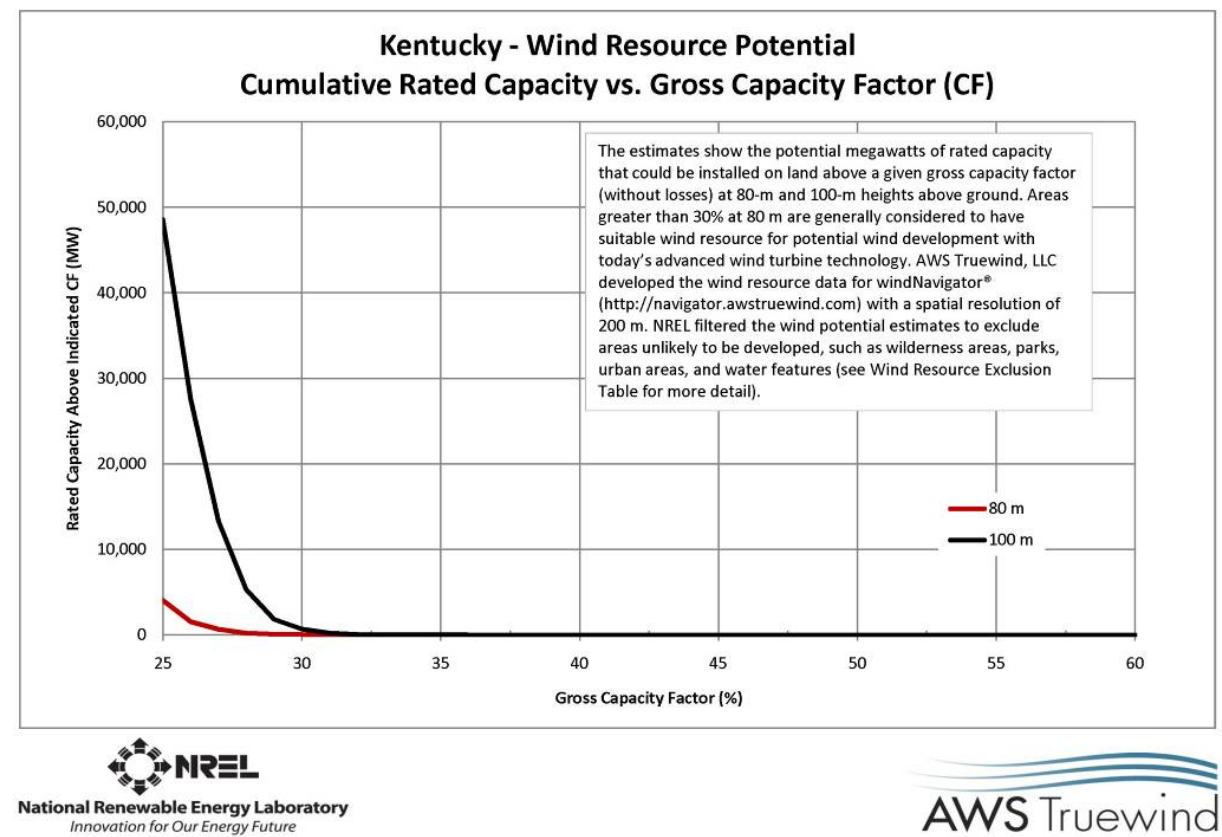

Fig. A.11. Kentucky wind resource potential: Cumulative rated capacity vs gross capacity factor (CF). (Source: NREL, 2010) 


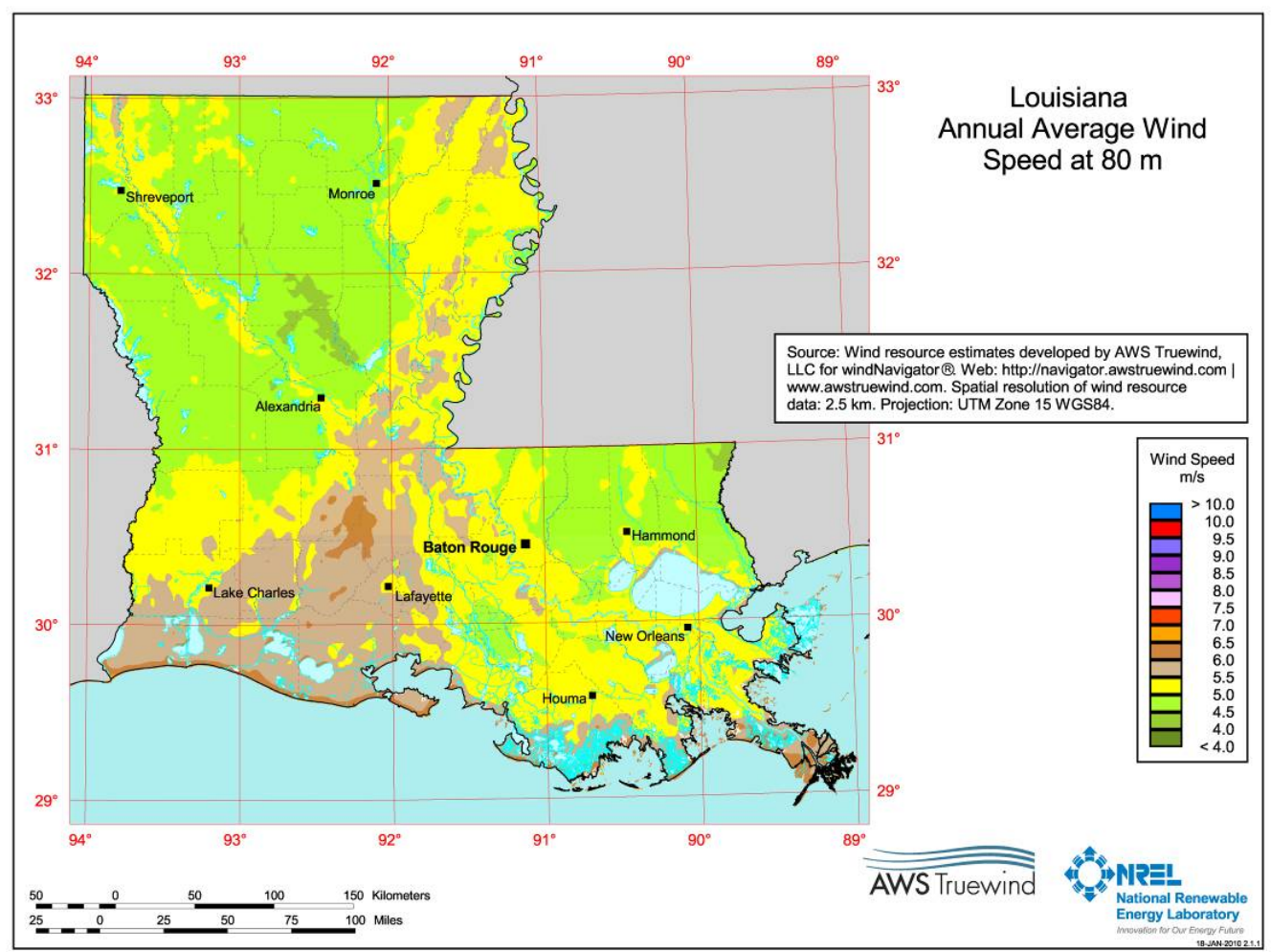

(Source: http://www.windpoweringamerica.gov/images/windmaps/la_80m.jpg).

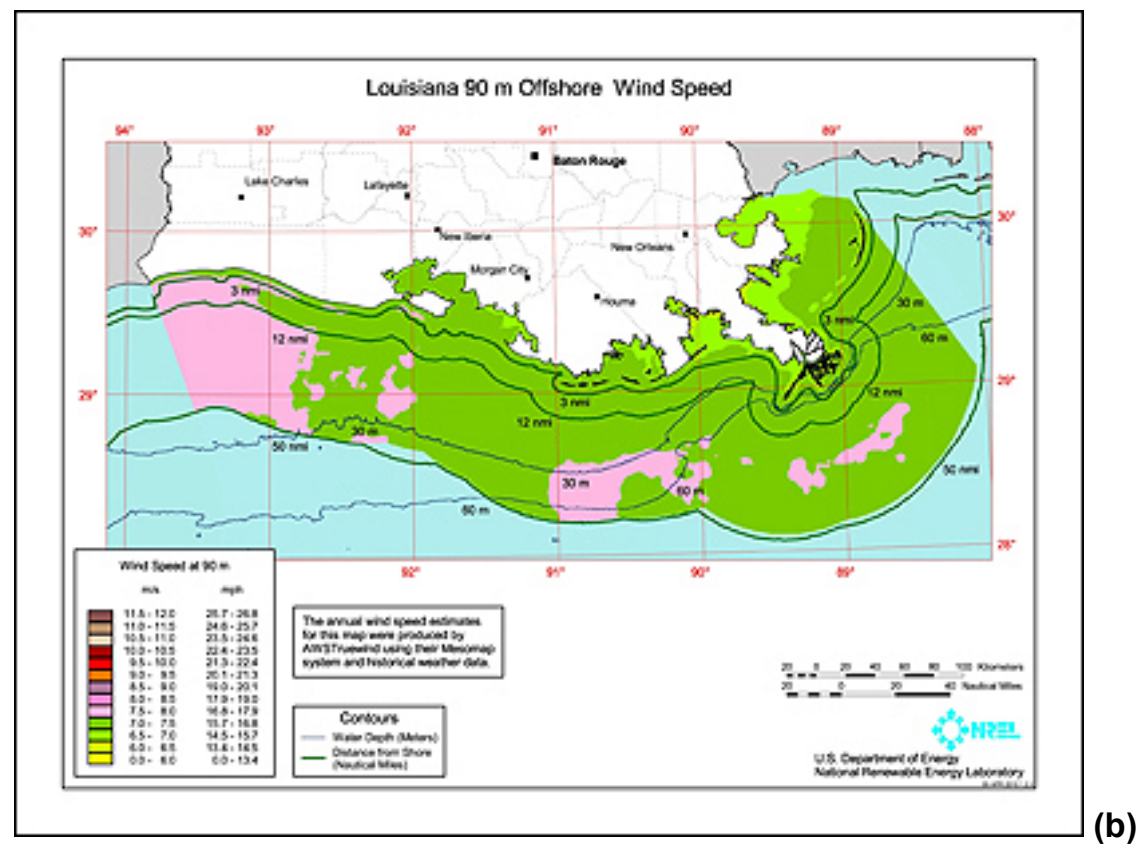

(Source: http://www.windpoweringamerica.gov/windmaps/offshore_states.asp?stateab=la).

Fig. A.12. (a) Louisiana annual average wind speed at $80 \mathrm{~m}$ and (b) Louisiana offshore wind resource at $90 \mathrm{~m}$ hub height. 


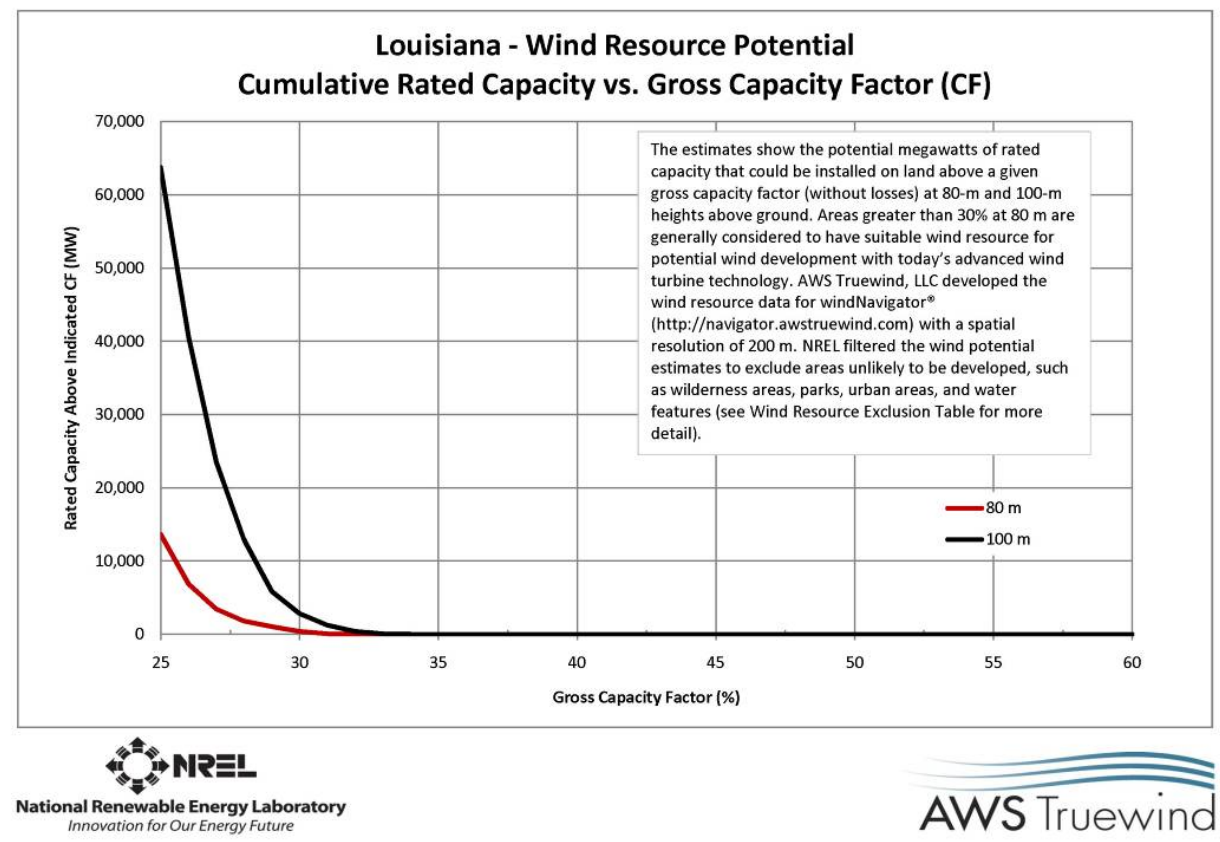

Fig. A.13. Louisiana wind resource potential: Cumulative rated capacity vs gross capacity factor (CF). (Source: NREL, 2010) 


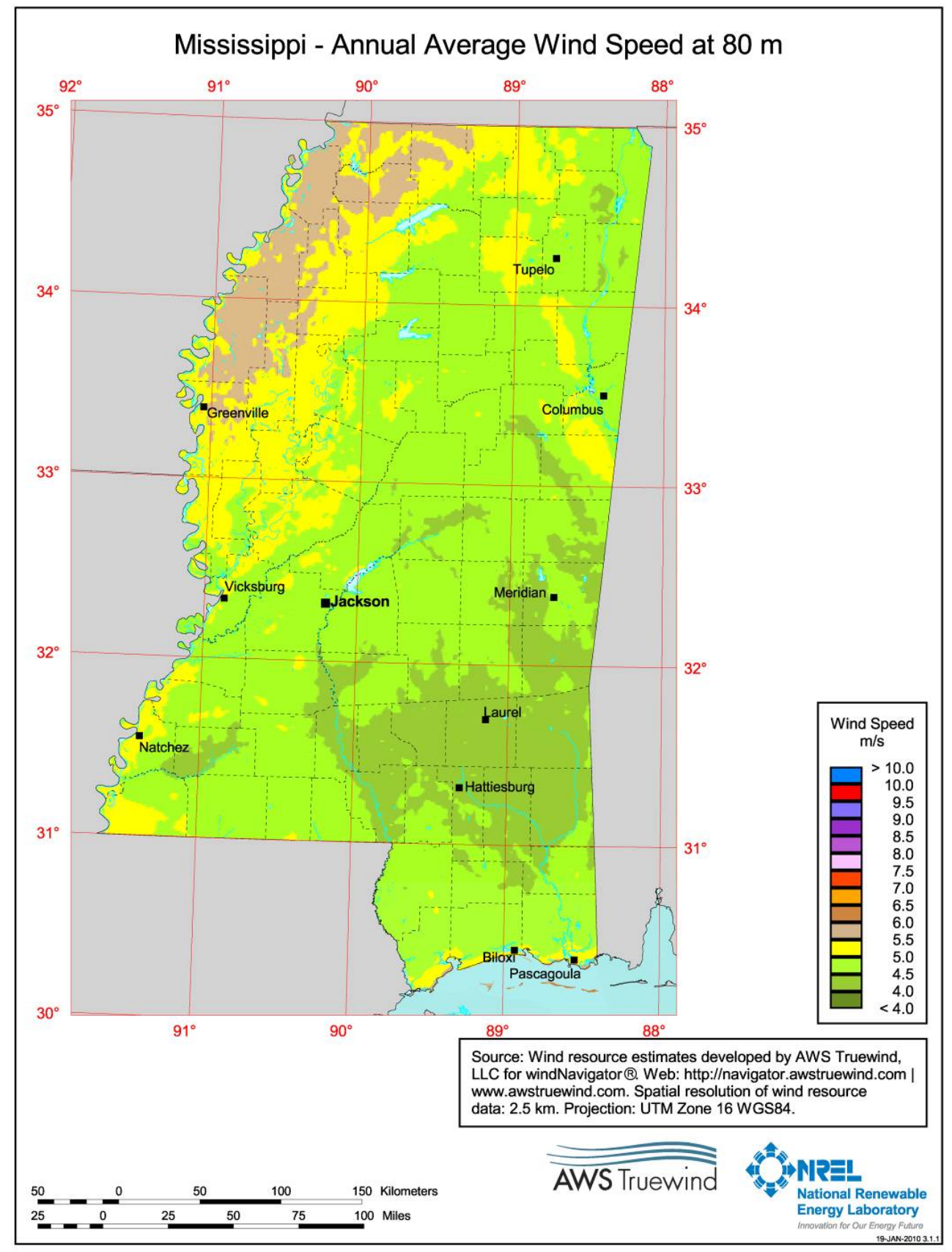

Fig. A.14. Mississippi annual average wind speed at $80 \mathrm{~m}$. (Source: National Renewable Energy Laboratory, 2010) http://www.windpoweringamerica.gov/images/ windmaps $/ \mathrm{ms} \_80 \mathrm{~m} . j p g$ 


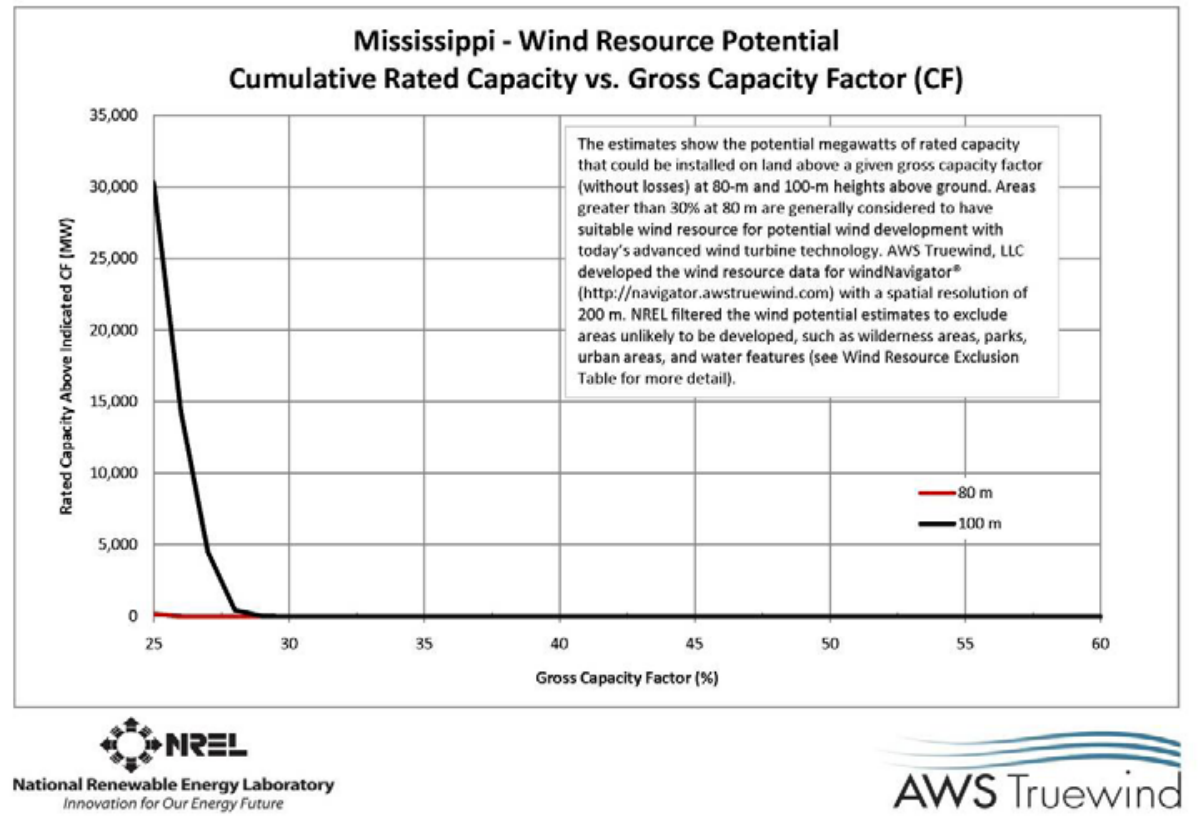

Fig. A.15. Mississippi wind resource potential: Cumulative rated capacity vs gross capacity factor (CF). (Source: NREL, 2010)

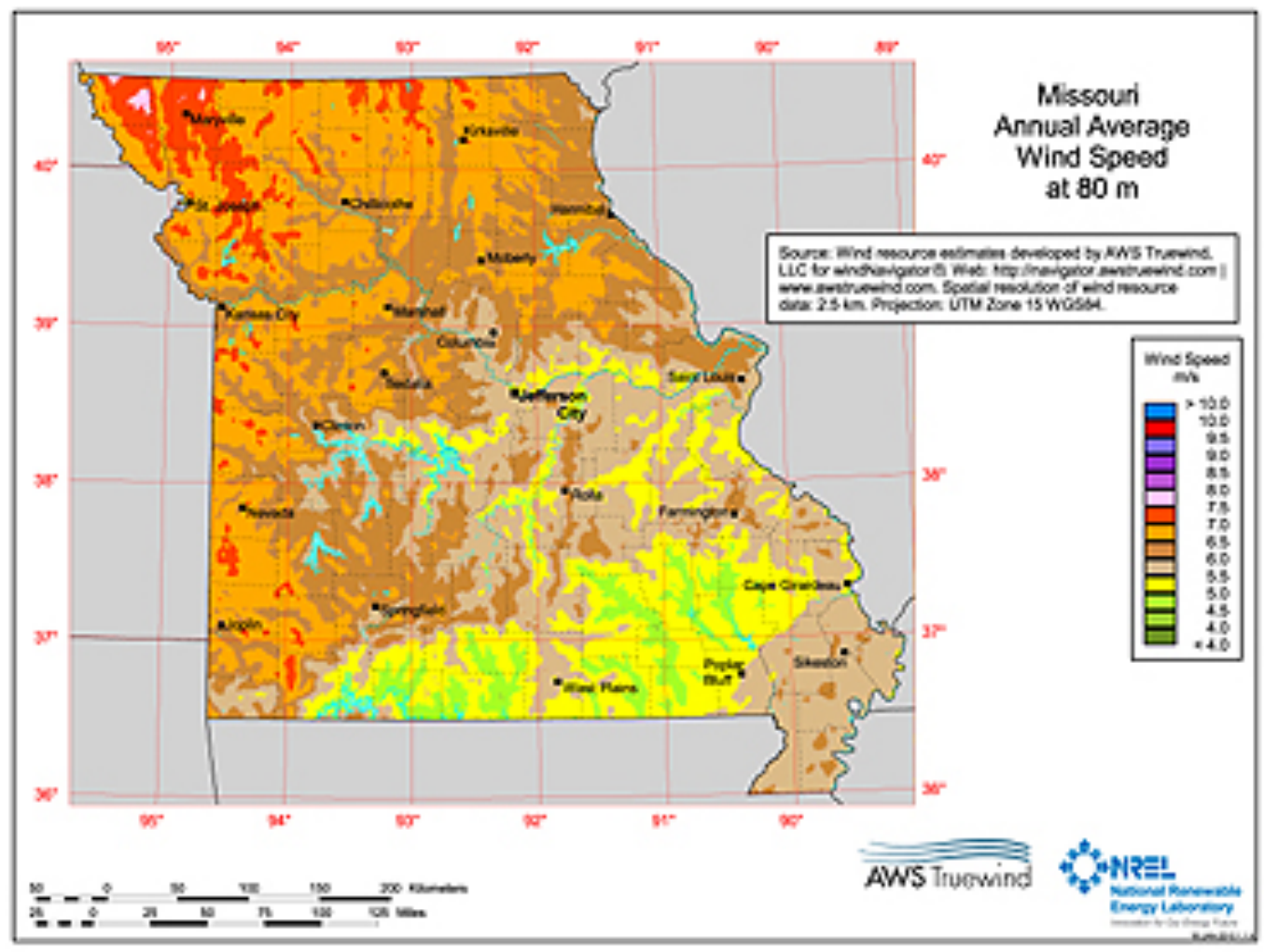

Fig. A.16. Missouri wind map shows the wind resource at 80 meters. (Source: NREL, 2010) http://www.windpoweringamerica.gov/images/windmaps/mo_80m.jpg 


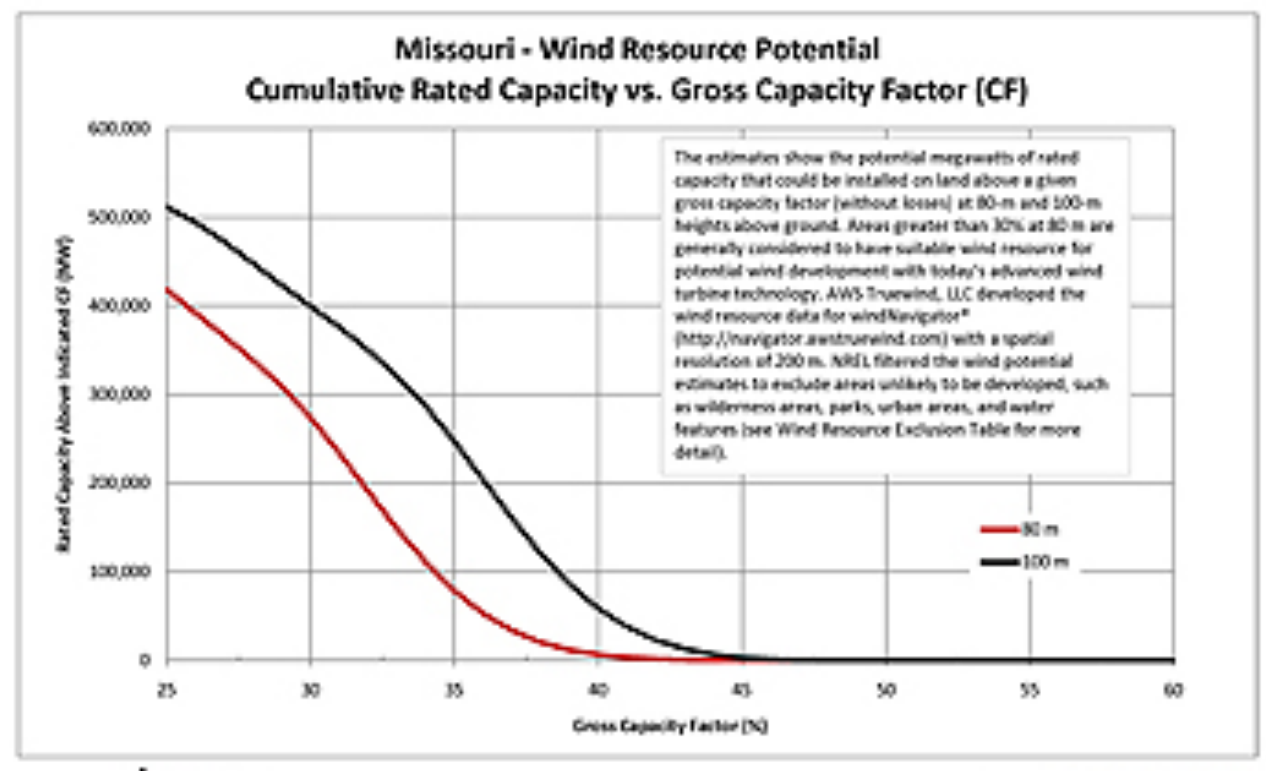

Fig. A.17. Missouri wind resource potential: Cumulative rated capacity vs gross capacity factor (CF). (Source: NREL, 2010)

North Carolina has wind resources consistent with utility-scale production. The good-to-excellent wind resource areas are concentrated in two regions. The first is along the Atlantic Coast and barrier islands. The second area is the higher ridge crests in western North Carolina. Note also that the older $50 \mathrm{~m}$ offshore data shows extensive outstanding offshore wind resources for North Carolina.

For North Carolina, the NREL published a factsheet on economic benefits, $\mathrm{CO}_{2}$ emissions reductions, and water conservation benefits from 1,000 MW of new wind power. Projected direct economic impacts for North Carolina include 1,628 new jobs with $\$ 188.5$ million to local economies during the construction phase and 243 new long-term jobs with $\$ 21.2$ million per year to local economies (NREL, 2009). In addition, projected indirect and induced economic impacts include 1,361 new jobs during the construction phase and 214 local jobs during the operational phase (NREL, 2009).

Oklahoma has wind resources consistent with utility-scale production. The best resource areas are located in the Panhandle and western parts of the states, but good resources are also located in the central and northeast corner of the state.

The capacity factor for Oklahoma wind resources is very important to the use of the resource. There is a nominal rated capacity of greater than $400 \mathrm{GW}$ with capacity factor over $35 \%$.

South Carolina has wind resources consistent with utility-scale production. The good-to-excellent resource areas are located on ridge crests located near the border of western North Carolina and Georgia. Other good resource areas are on exposed capes along the Atlantic Coast.

Tennessee has wind resources consistent with utility-scale production. The good-to-excellent wind resource areas are concentrated on ridge crests in the eastern part of the state near the North Carolina border. Two notable areas are the ridges southeast of Knoxville and south of Johnson City. There are areas along these ridge crests that are estimated to have outstanding-to-superb resources.

For Tennessee, the NREL published a factsheet on economic benefits, $\mathrm{CO}_{2}$ emissions reductions, and water conservation benefits from 1,000 MW of new wind power. Projected direct economic impacts for Tennessee include 1,677 new jobs with $\$ 188.5$ million to local economies during the construction phase and 234 new long-term jobs with \$21.2 million per year to local economies (NREL, 2009). In addition, projected indirect and induced economic impacts include 1,489 new jobs during the construction phase and 194 local jobs during the operational phase (NREL, 2009). Note however, the Tennessee capacity factors are below $30 \%$, which will require a larger number of wind turbines to provide consistent output. 


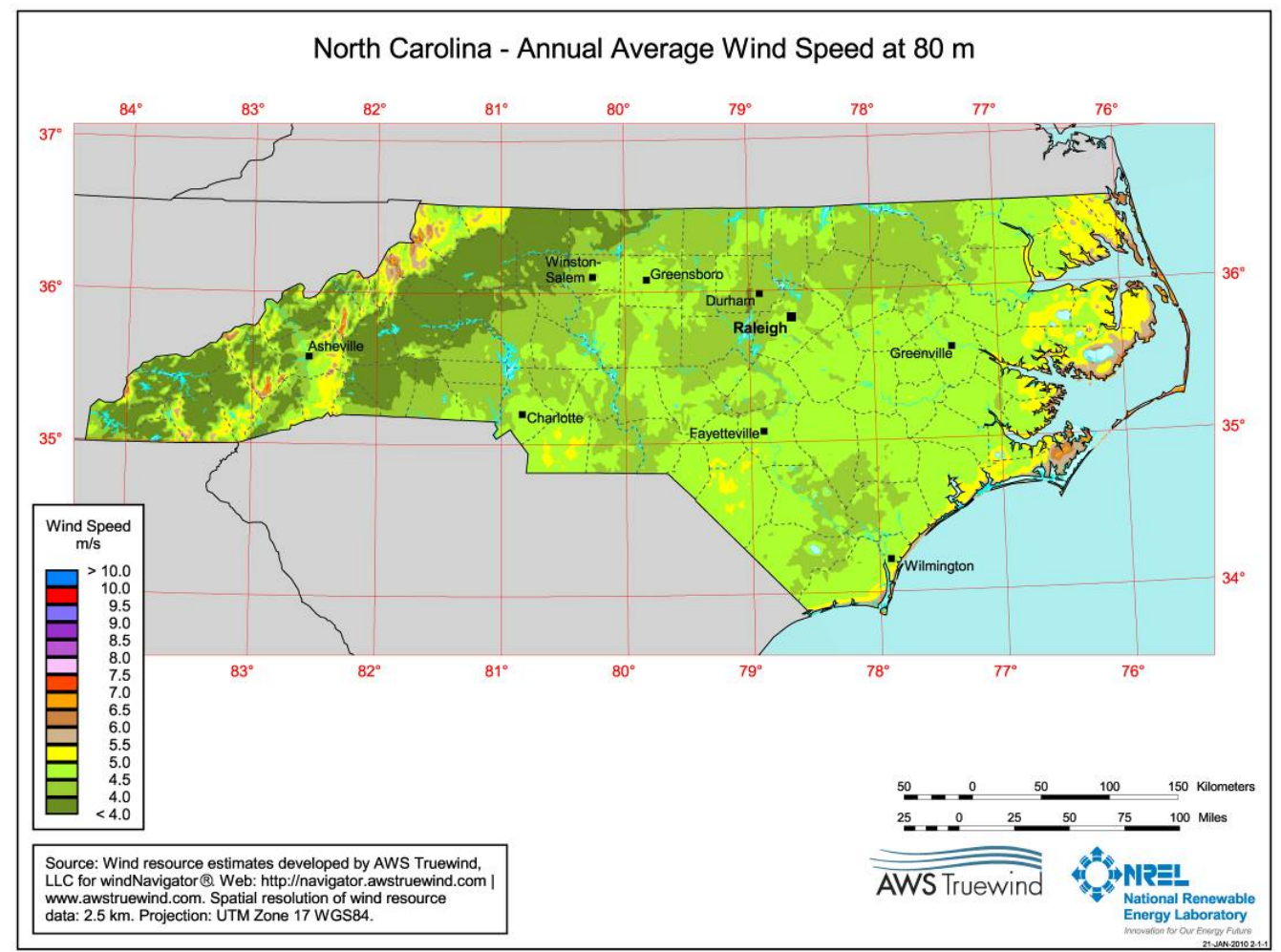

Fig. A.18. North Carolina annual average wind speed at $80 \mathrm{~m}$. (Source: http://www.windpoweringamerica.gov/images/windmaps/nc_80m.jpg) 


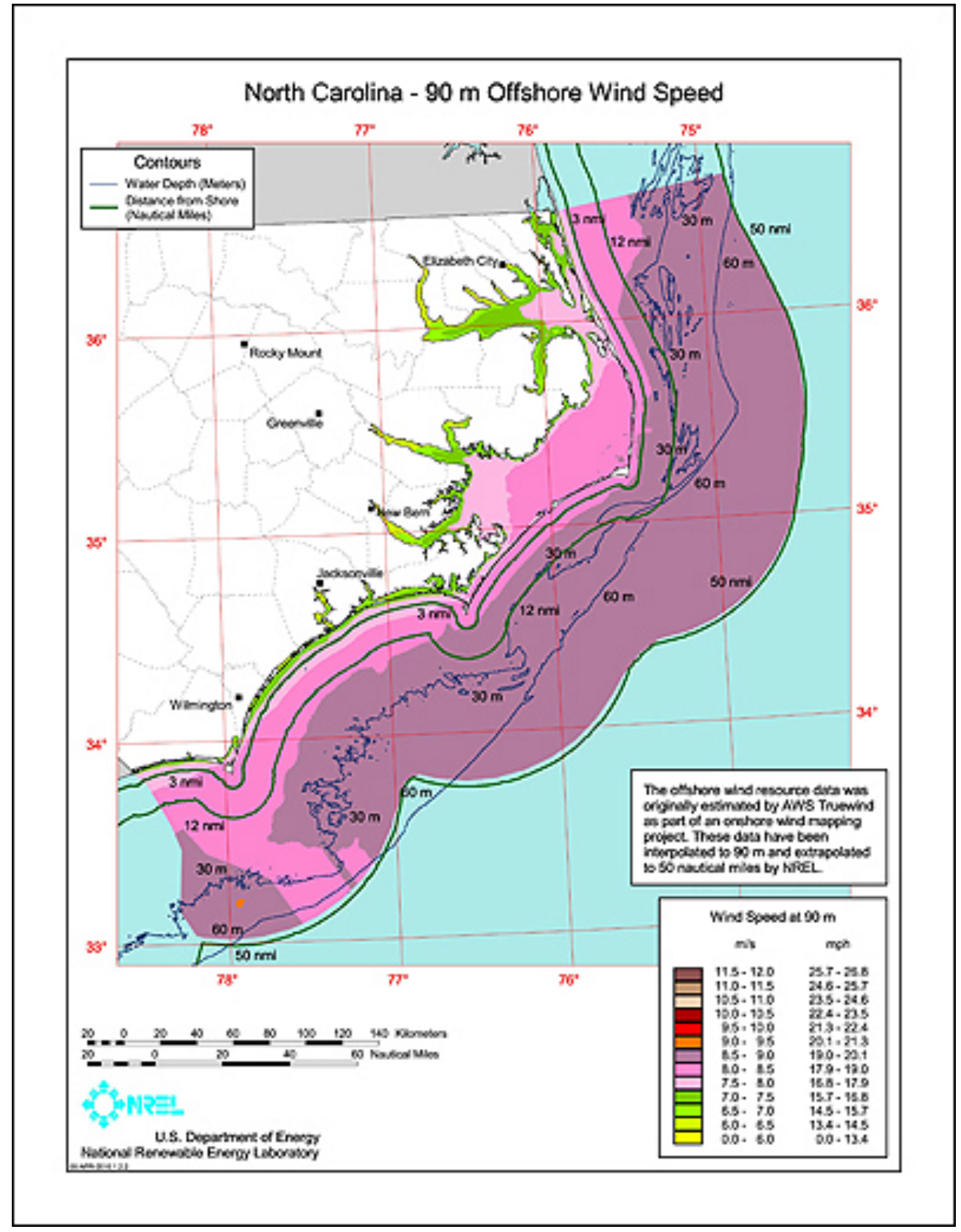

Fig. A.19. North Carolina annual average offshore wind speed at $90 \mathrm{~m}$ hub height. (Source: http://www.windpoweringamerica.gov/windmaps/ offshore_states.asp?stateab=nc) 

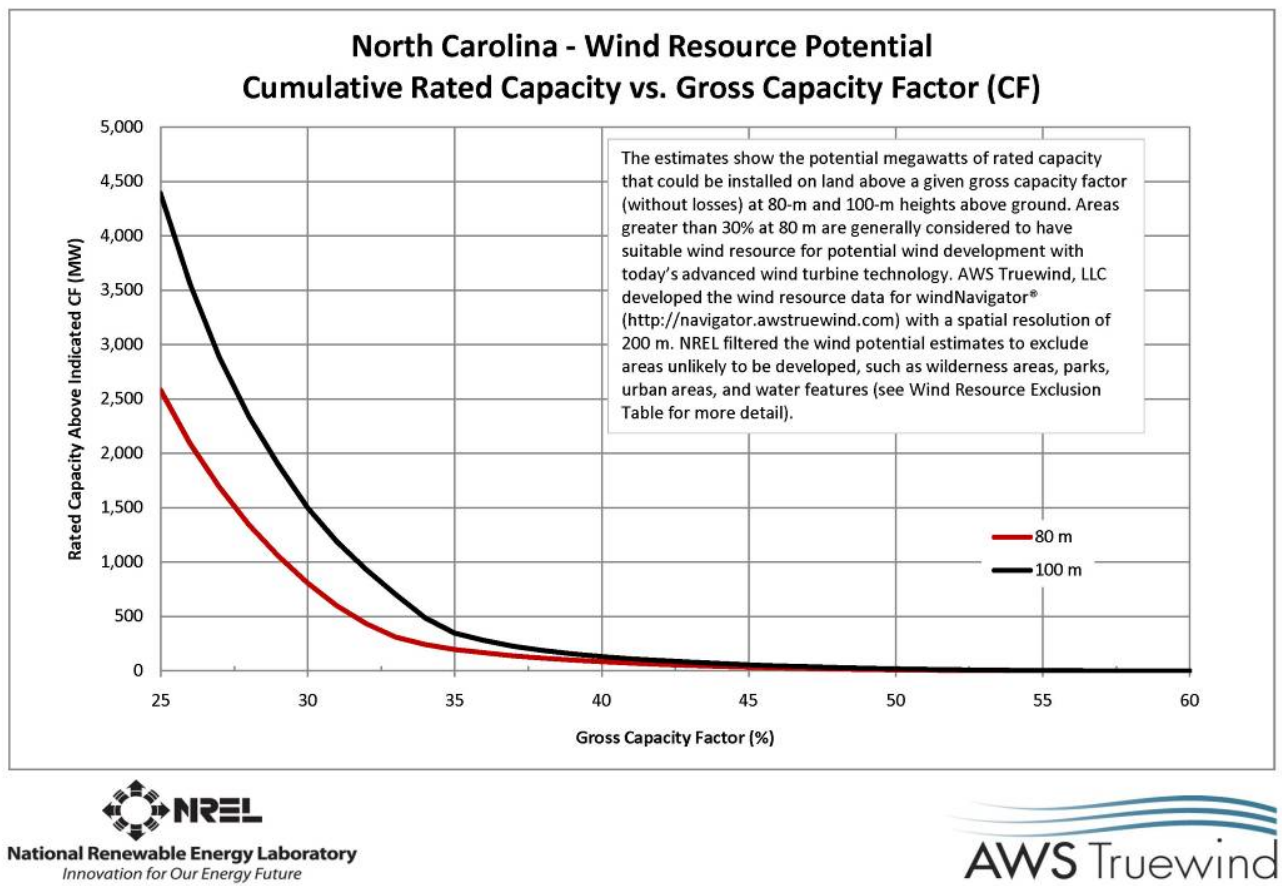

AWS Truewind

Fig. A.20. North Carolina wind resource potential: Cumulative rated capacity vs gross capacity factor (CF). (Source: NREL, 2010)

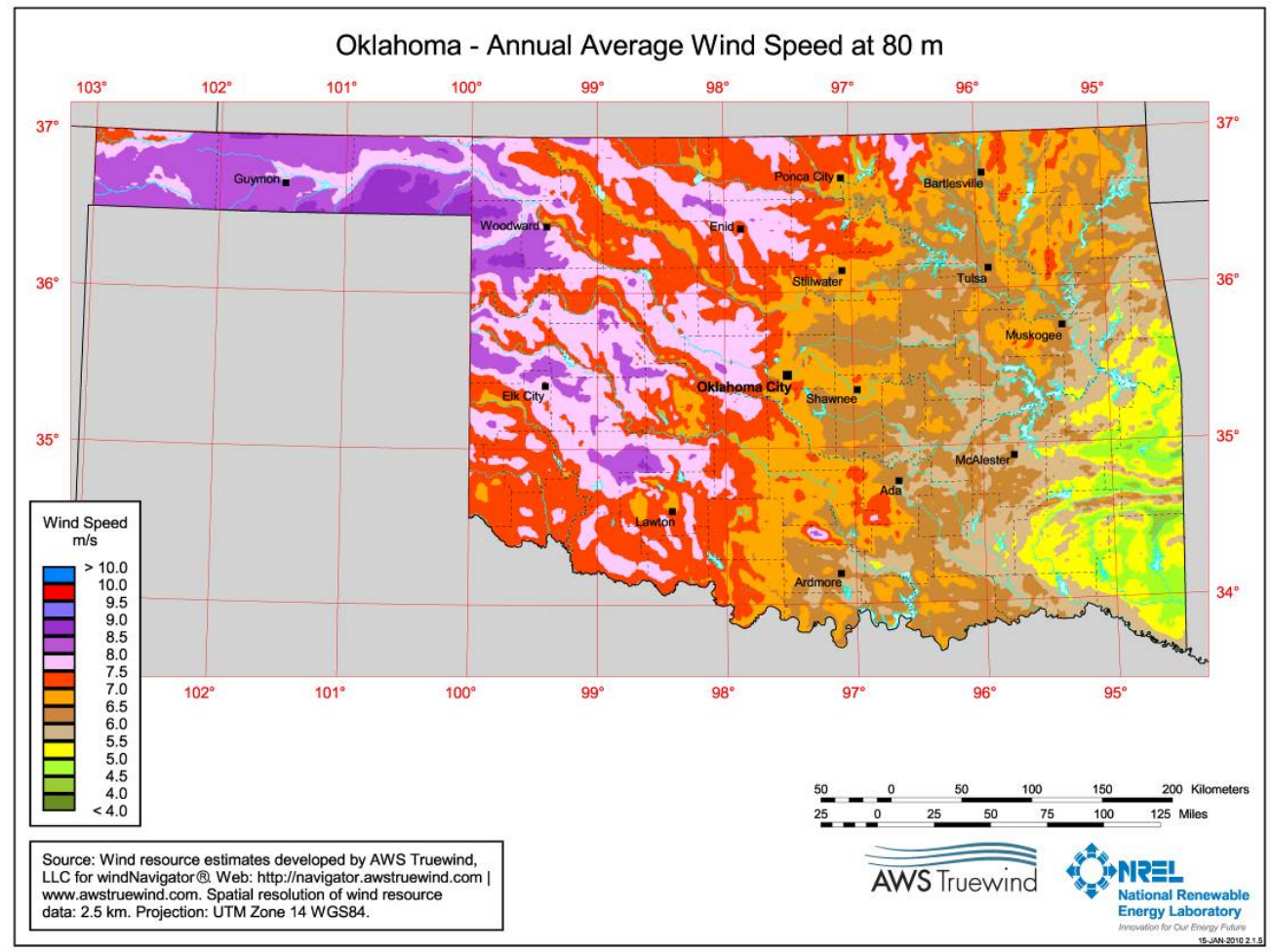

Fig. A.21. Annual average wind speed at 80 m. (Source: NREL, 2010) http://www.windpoweringamerica.gov/images/windmaps/mo_80m.jpg 


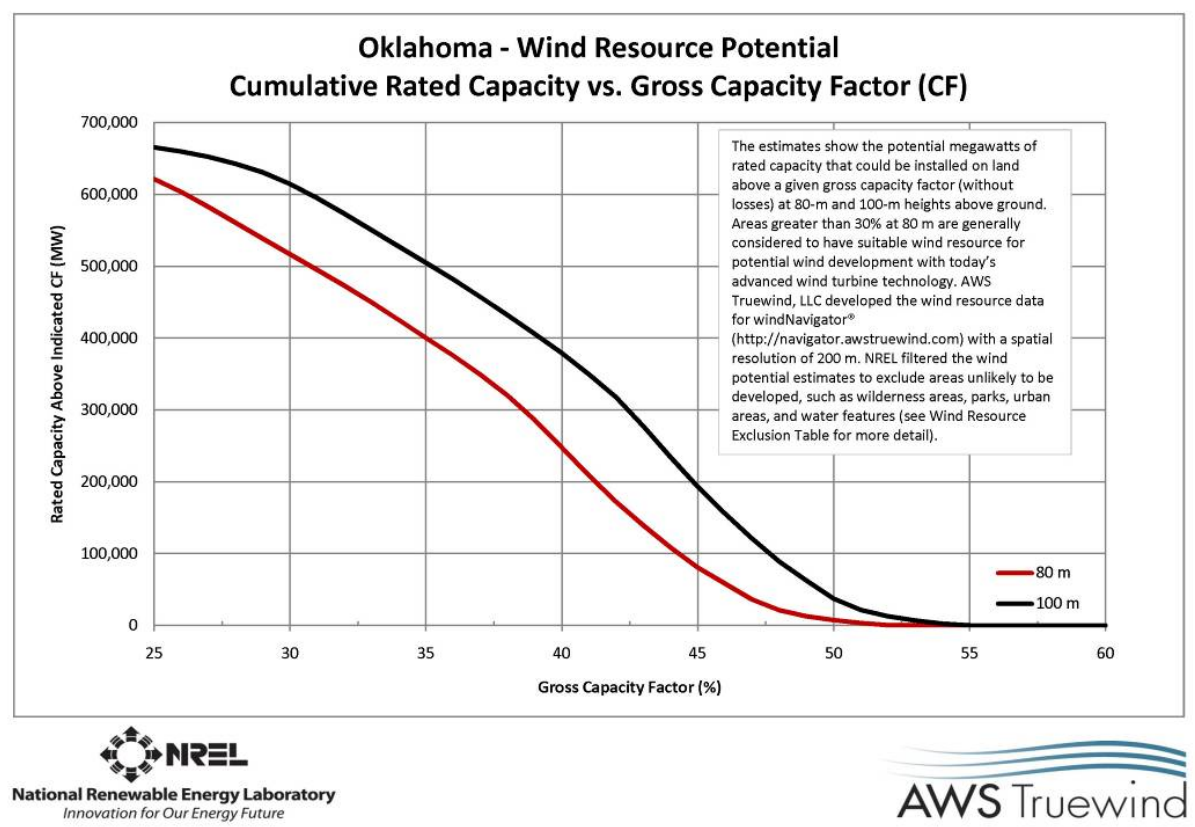

Fig. A.22. Oklahoma wind resource potential: Cumulative rated capacity vs gross capacity factor (Cf). (Source: NREL, 2010)

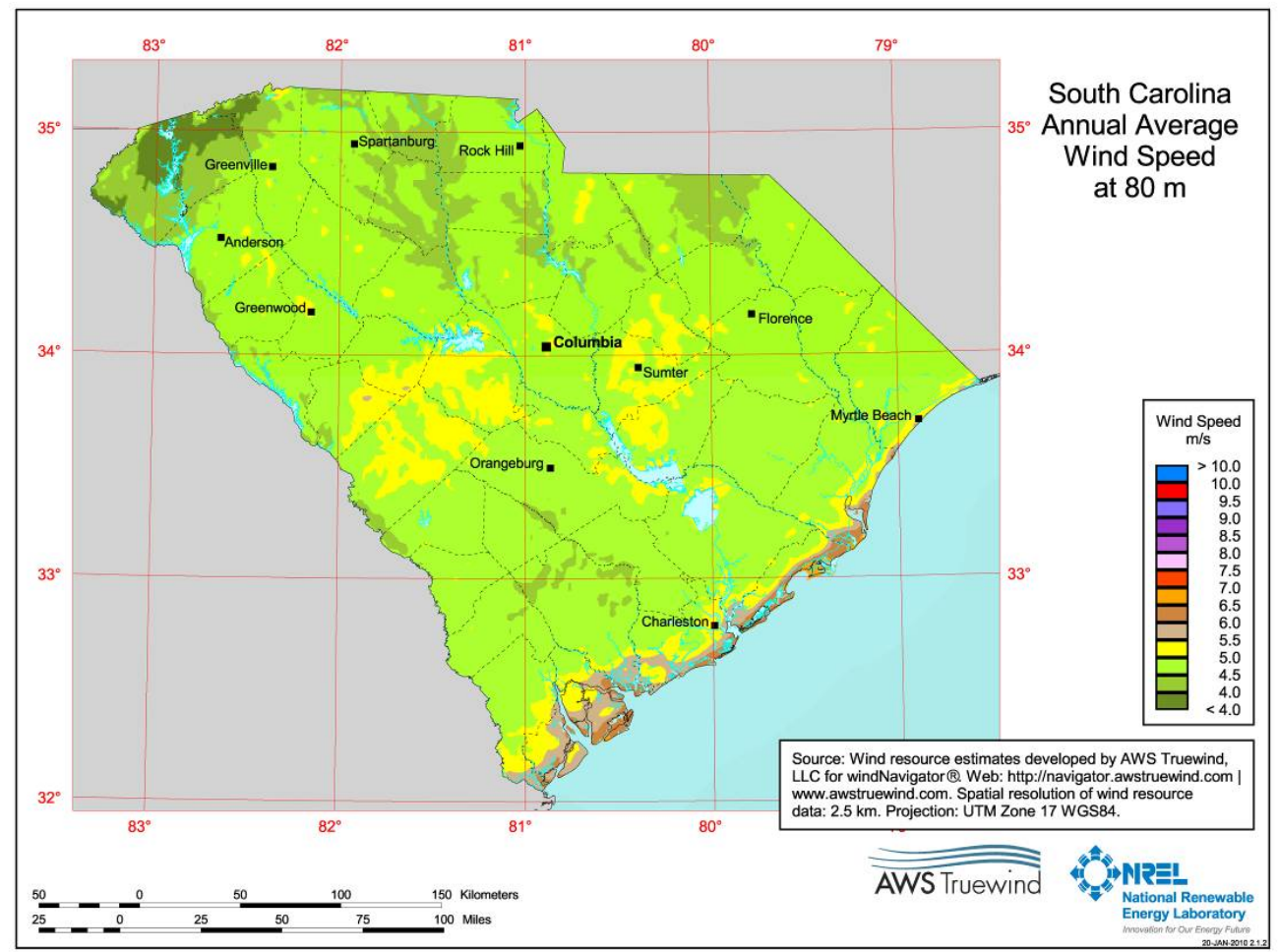

Fig. A.23. South Carolina annual average wind speed at $80 \mathrm{~m}$. (Source: http://www.windpoweringamerica.gov/images/windmaps/sc_80m.jpg) 


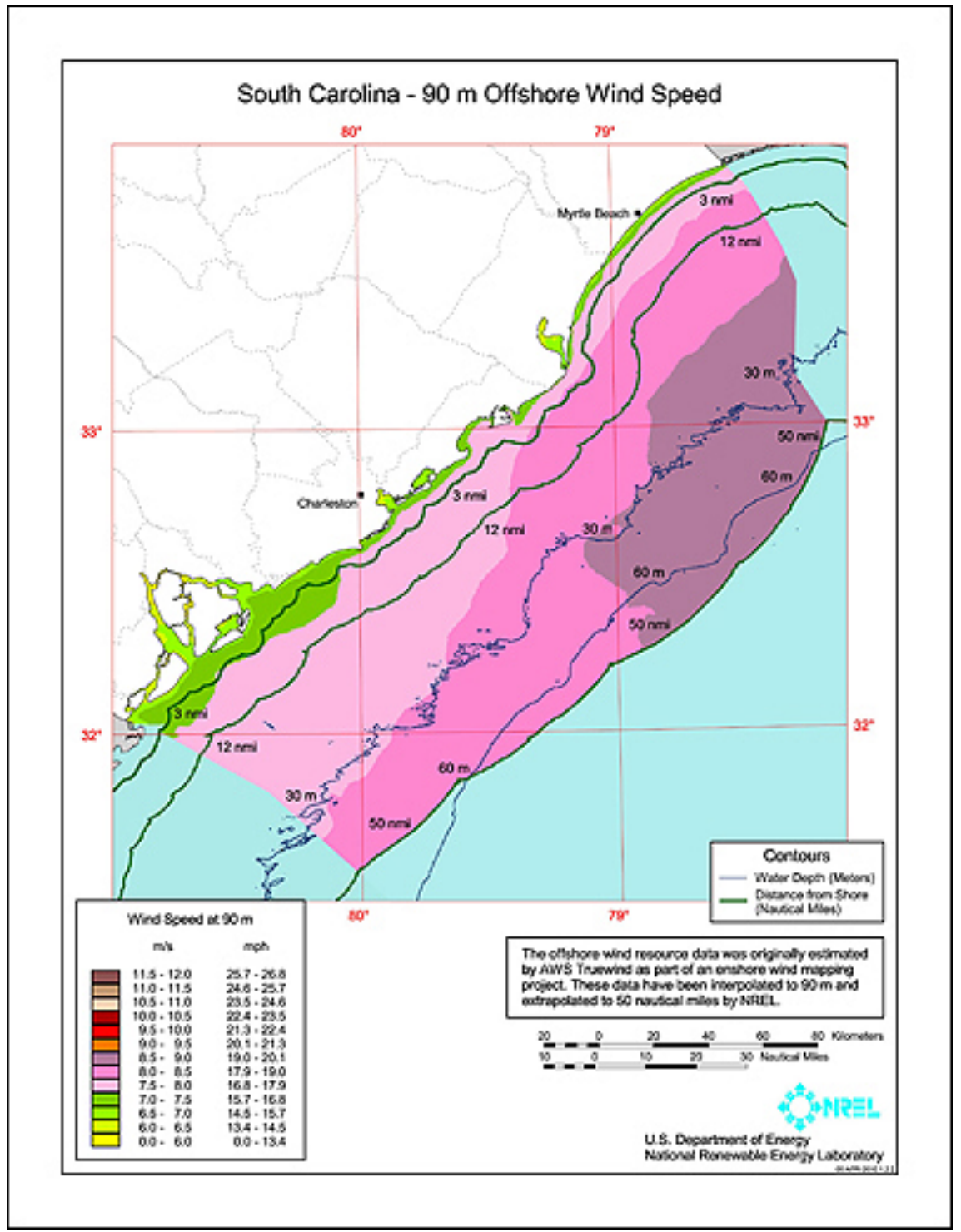

Fig. A.24. South Carolina annual average offshore wind speed at $90 \mathrm{~m}$ hub height. (Source: http://www.windpoweringamerica.gov/windmaps/ offshore_states.asp?stateab $=\mathrm{sc}$ ) 

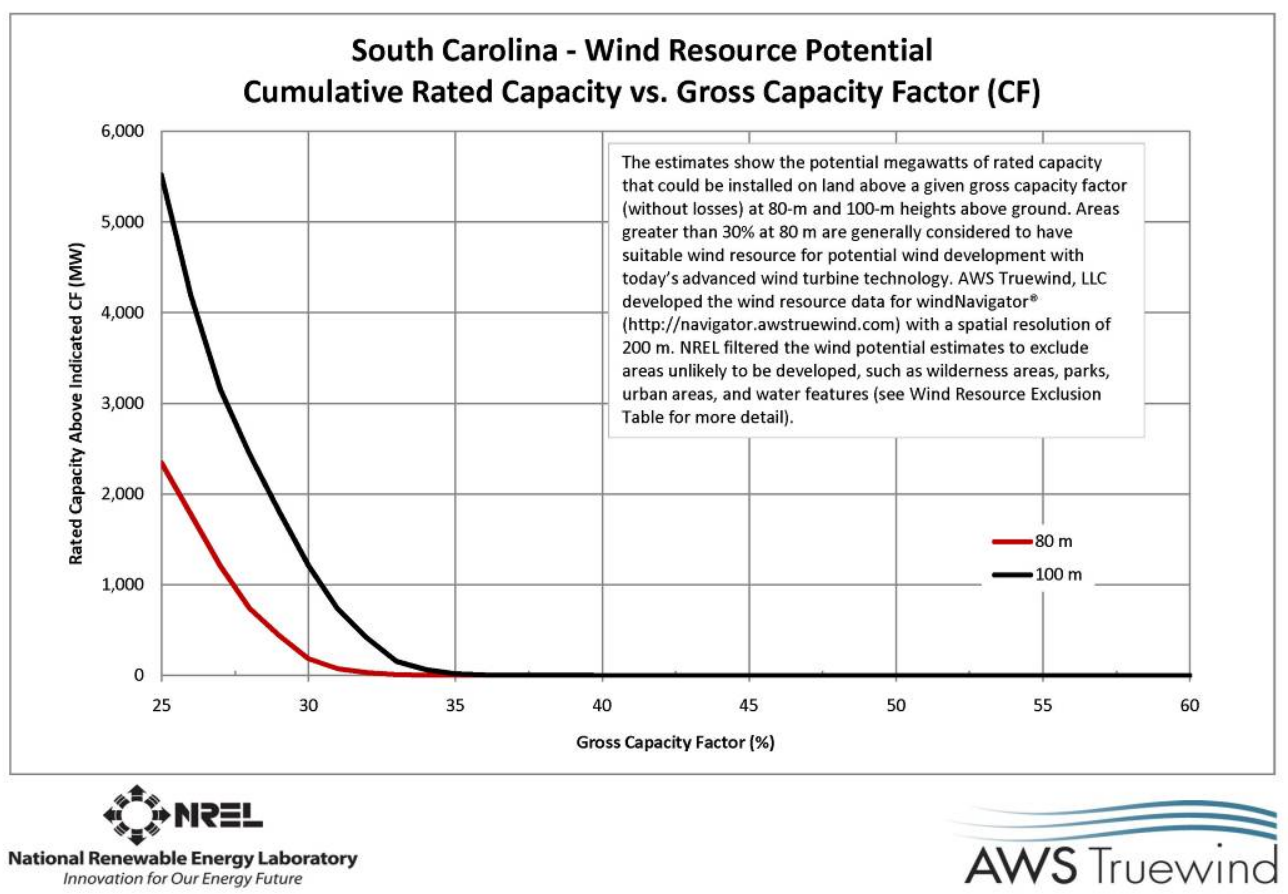

Fig. A.25. South Carolina wind resource potential: Cumulative rated capacity vs gross capacity factor (CF). (Source: NREL, 2010)

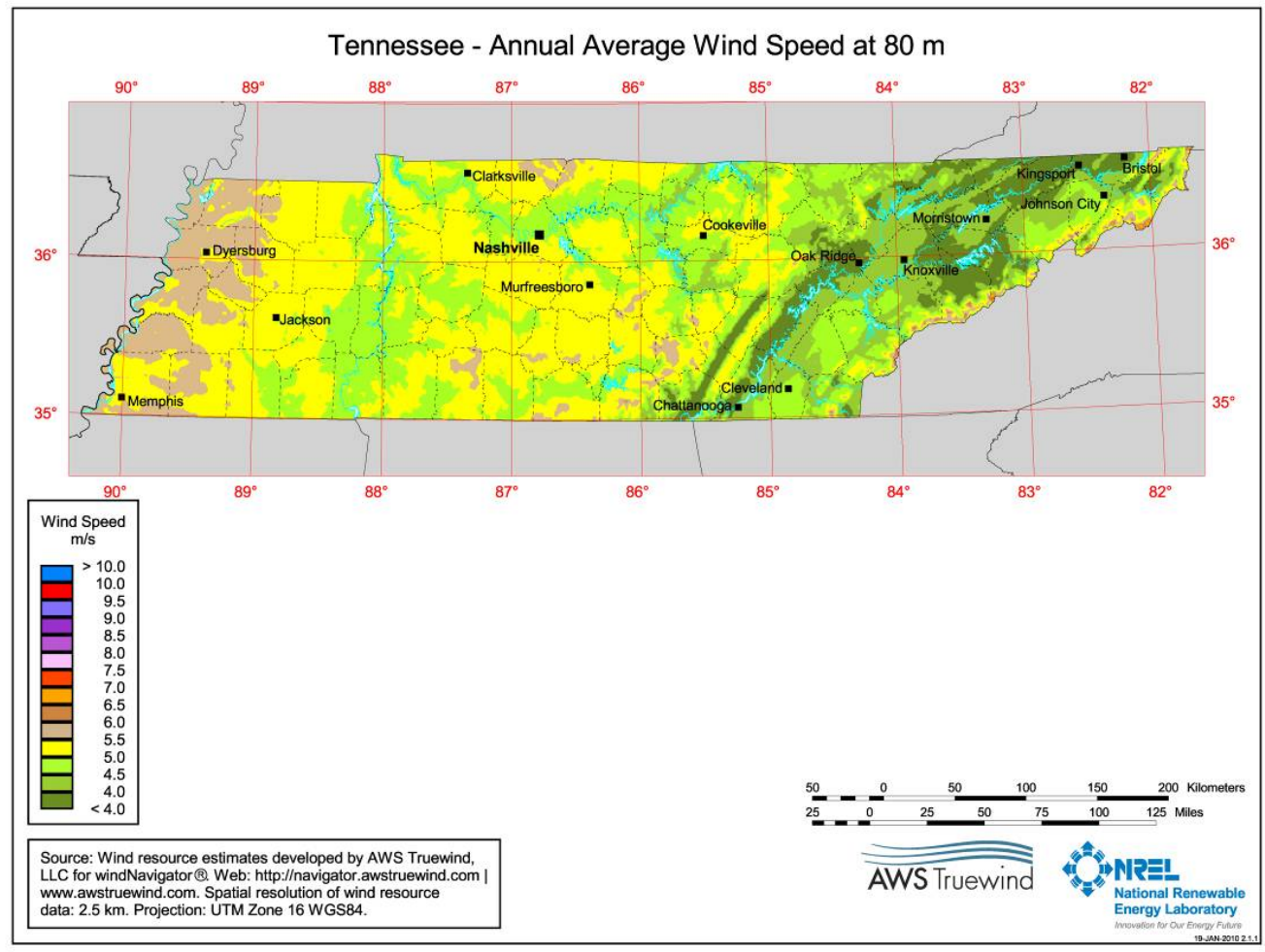

Fig. A.26. Tennessee annual average wind speed at $80 \mathrm{~m}$. (Source: National Renewable Energy Laboratory, 2010) http://www.windpoweringamerica.gov/images/ windmaps/tn_80m.jpg 


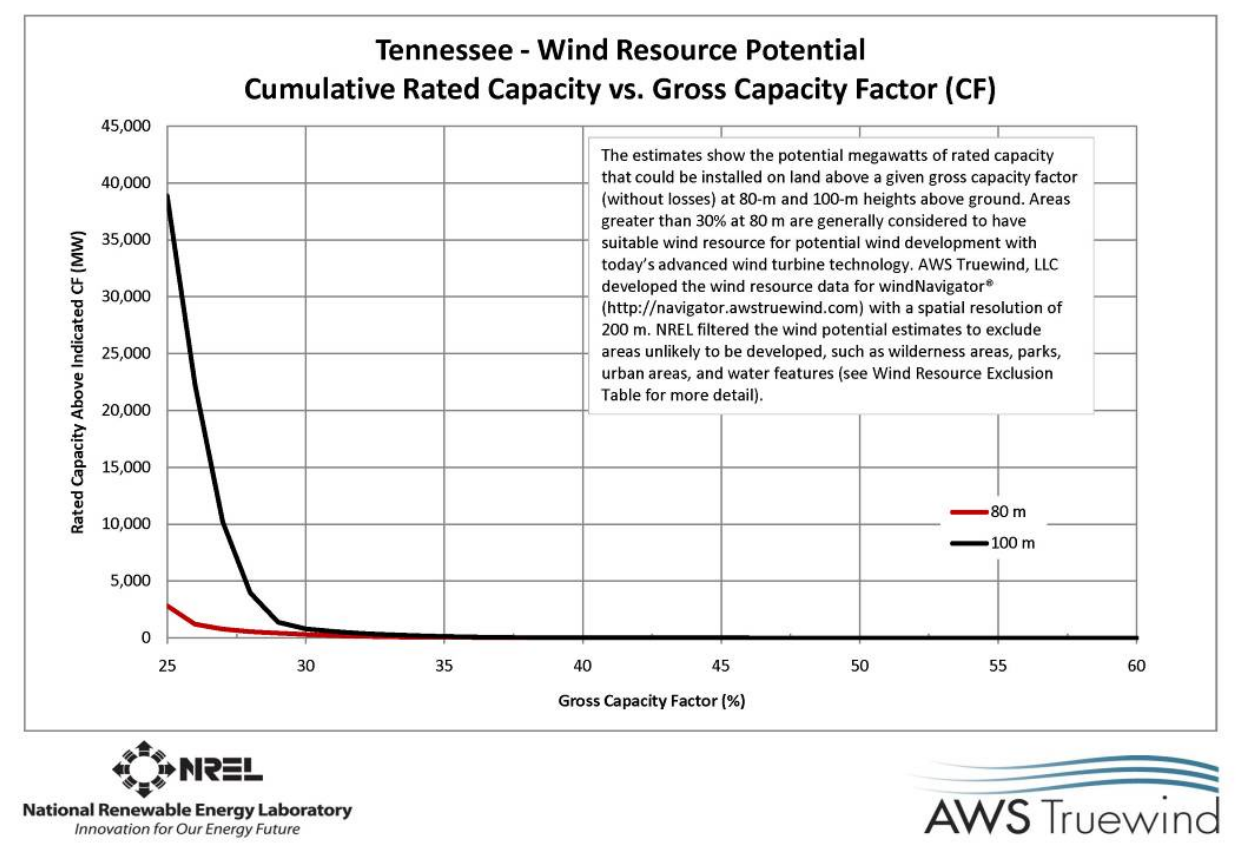

Fig. A.27. Tennessee wind resource potential: Cumulative rated capacity vs gross capacity factor (CF). (Source: NREL, 2010)

Texas has excellent utility level wind energy resources consistent with utility-scale production. The excellent resource areas are located in the Panhandle and central parts of the state between San Angelo and Odessa.

Virginia has wind resources consistent with utility-scale production. Several areas of the state are estimated to have good-to-excellent wind resource. These include the Atlantic Coast along the Delmarva Peninsula and the Virginia Beach area, the ridge crests in the north-central part of the state, and ridge crests near the borders of West Virginia and North Carolina.

For Virginia, the NREL published a factsheet on economic benefits, $\mathrm{CO}_{2}$ emissions reductions, and water conservation benefits from 1,000 MW of new wind power. Projected direct economic impacts for Virginia include 1645 new jobs with \$207.4 million to local economies during the construction phase and 230 new long-term jobs with $\$ 21.2$ million per year to local economies (NREL, 2008). In addition, projected indirect and induced economic impacts include 1,384 new jobs during the construction phase and 184 local jobs during the operational phase (NREL, 2008).

West Virginia has wind resources consistent with utility-scale production. The good-to-excellent wind resource areas are concentrated on ridge crests in the eastern part of the state just south of a Martinsburg-Clarksburg line. There are scattered areas along these ridge crests that are estimated to have outstanding-to-superb resources.

For West Virginia, the NREL published a factsheet on economic benefits, $\mathrm{CO}_{2}$ emissions reductions, and water conservation benefits from 1,000 MW of new wind power. Projected direct economic impacts for West Virginia include 1,668 new jobs with $\$ 188.5$ million to local economies during the construction phase and 266 new long-term jobs with $\$ 21.2$ million per year to local economies (NREL, 2008). In addition, projected indirect and induced economic impacts include 1,412 new jobs during the construction phase and 153 local jobs during the operational phase (NREL, 2008). 


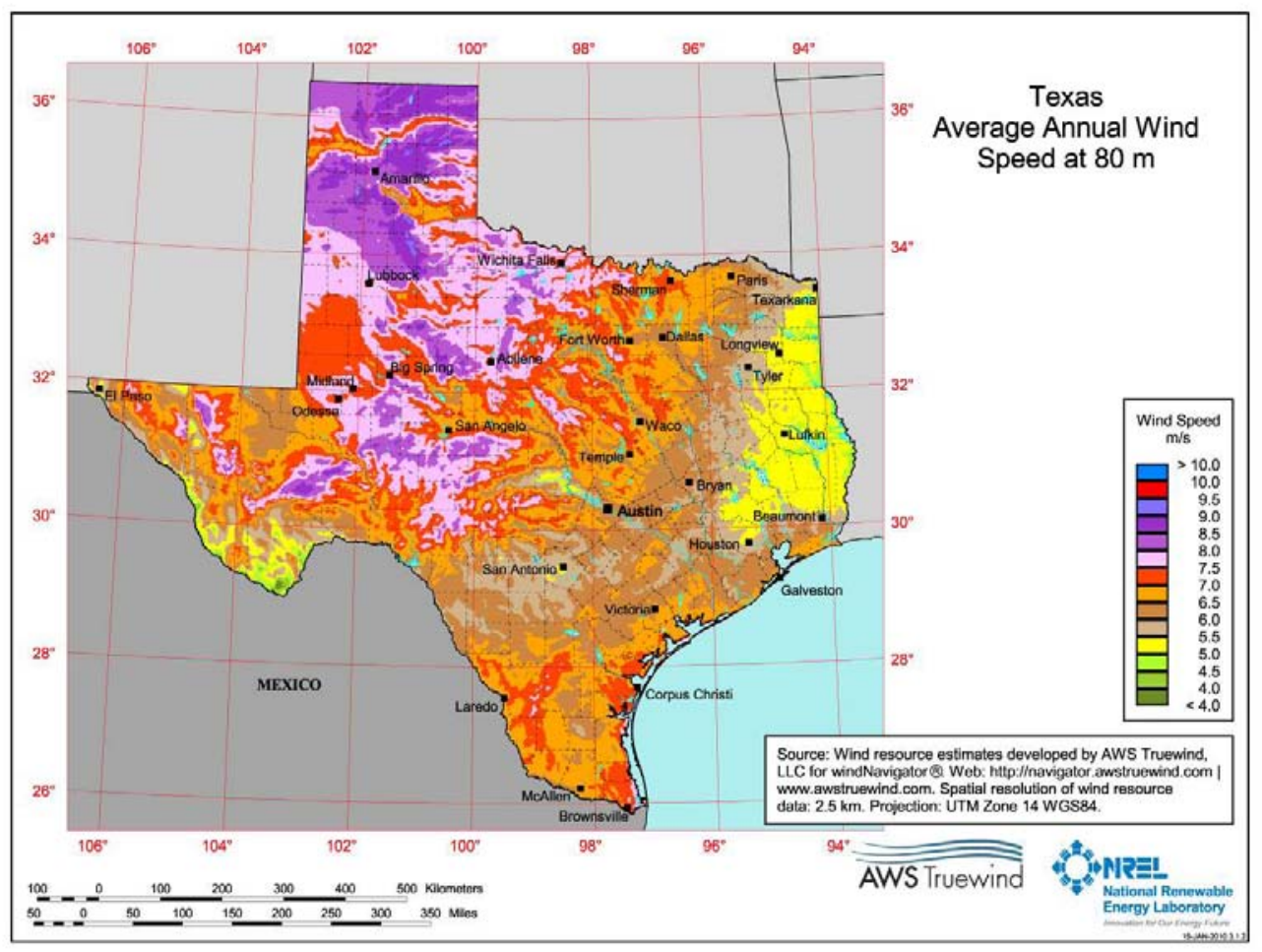

Fig. A.28. Wind resource in Texas at 80 m. (Source: NREL, 2010)

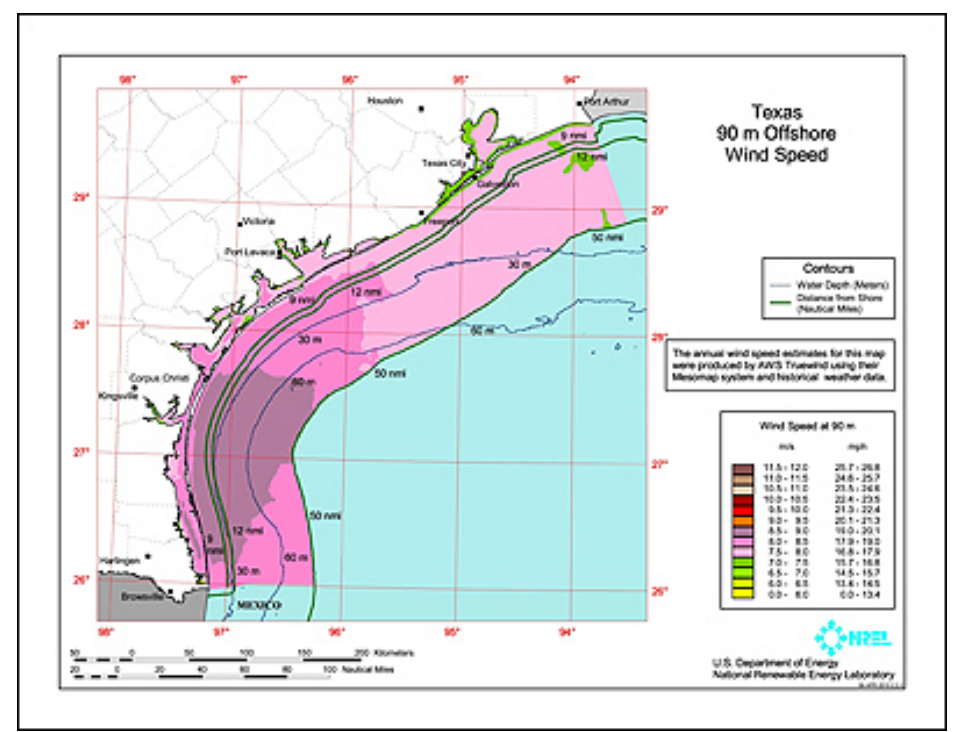

Fig. A.29. Texas offshore wind speed at $90 \mathrm{~m}$ hub height. (Source: http://www.windpoweringamerica.gov/windmaps/ offshore_states.asp?stateab $=\mathrm{tx}$ ) 


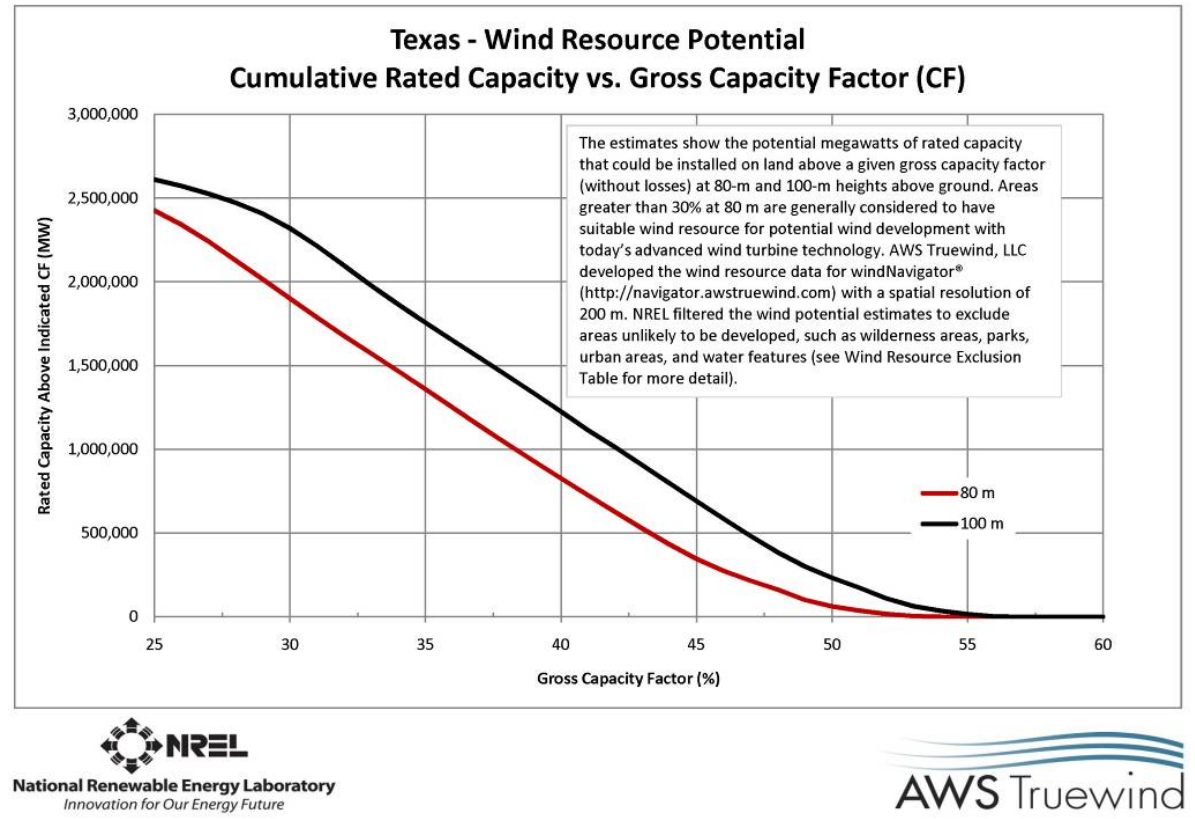

Fig. A.30. Texas wind resource potential: Cumulative rated capacity vs gross capacity factor (CF). (Source: NREL, 2010) 


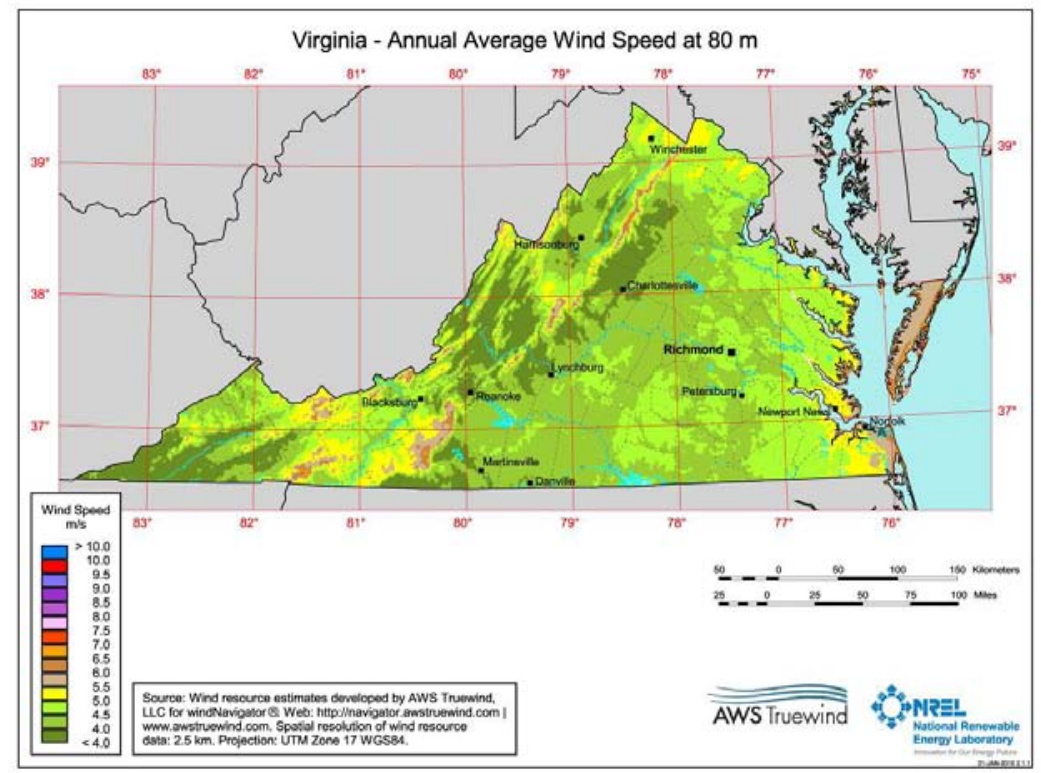

(a)

(Source: http://www.windpoweringamerica.gov/images/windmaps/va_80m.jpg)

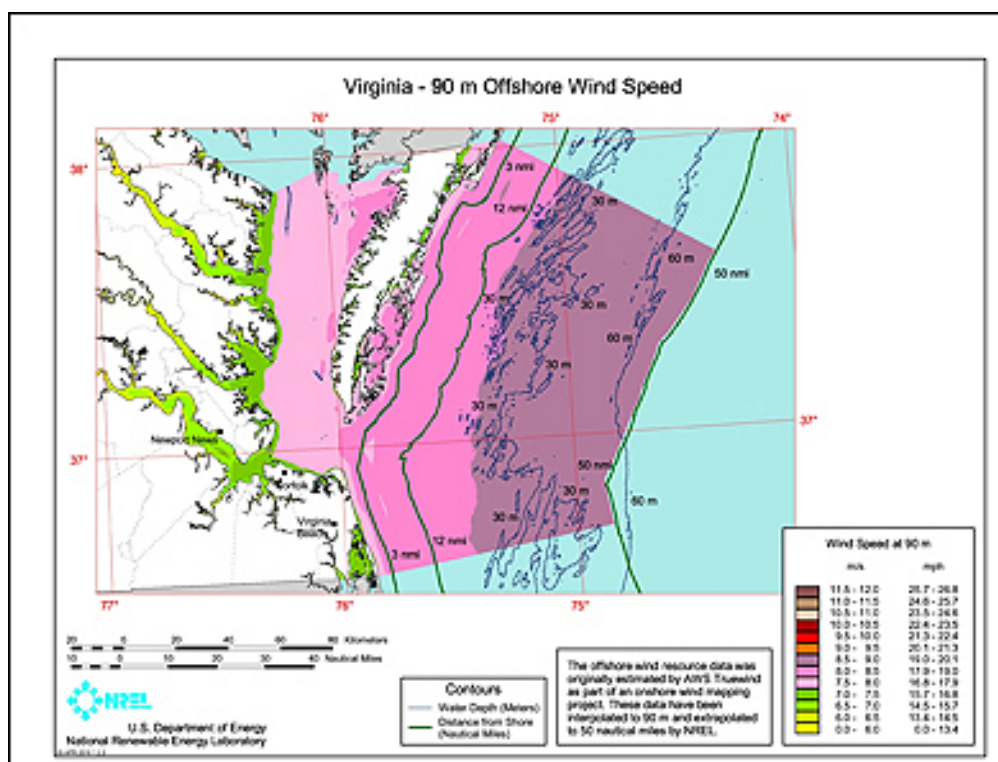

(b)

(Source: http://www.windpoweringamerica.gov/windmaps/offshore_states.asp?stateab=va)

Fig. A.31. (a) Virginia annual average wind speed at $80 \mathrm{~m}$ and (b) Virginia offshore wind velocity at $90 \mathrm{~m}$ hub height. 


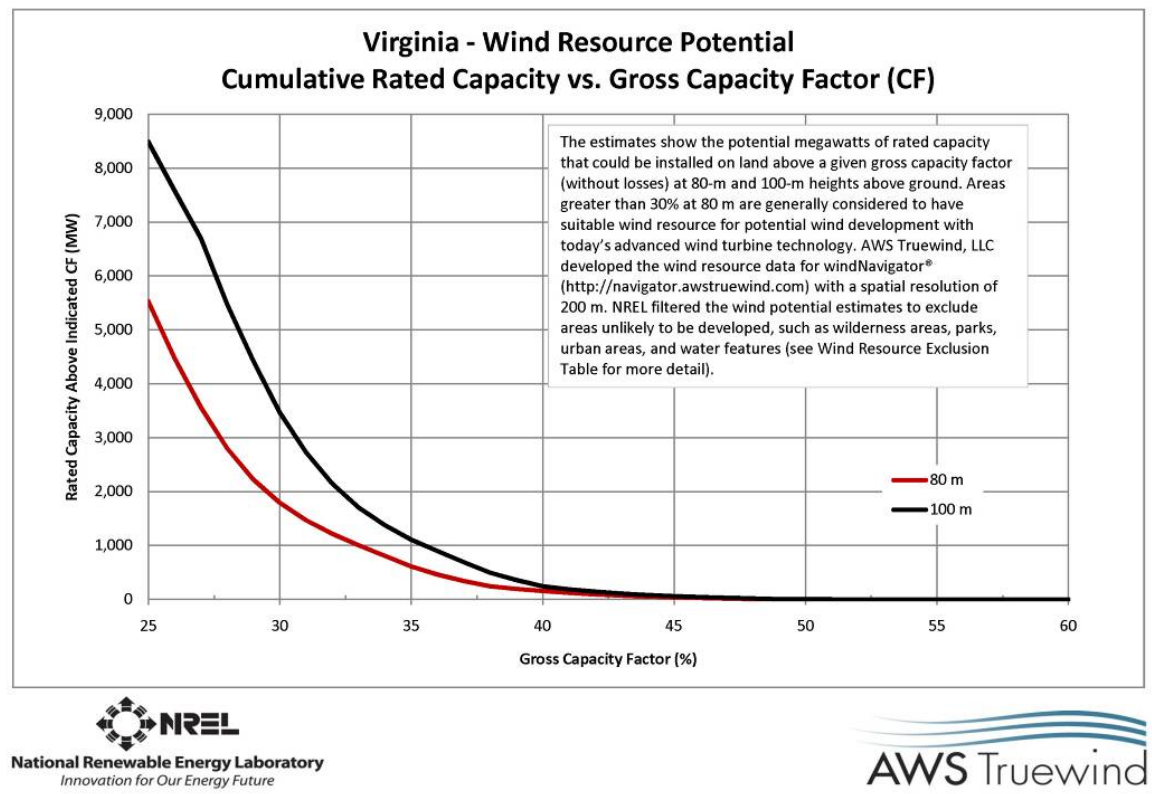

Fig. A.32. Virginia wind resource potential: Cumulative rated capacity vs gross capacity factor (CF). (Source: NREL, 2010) 


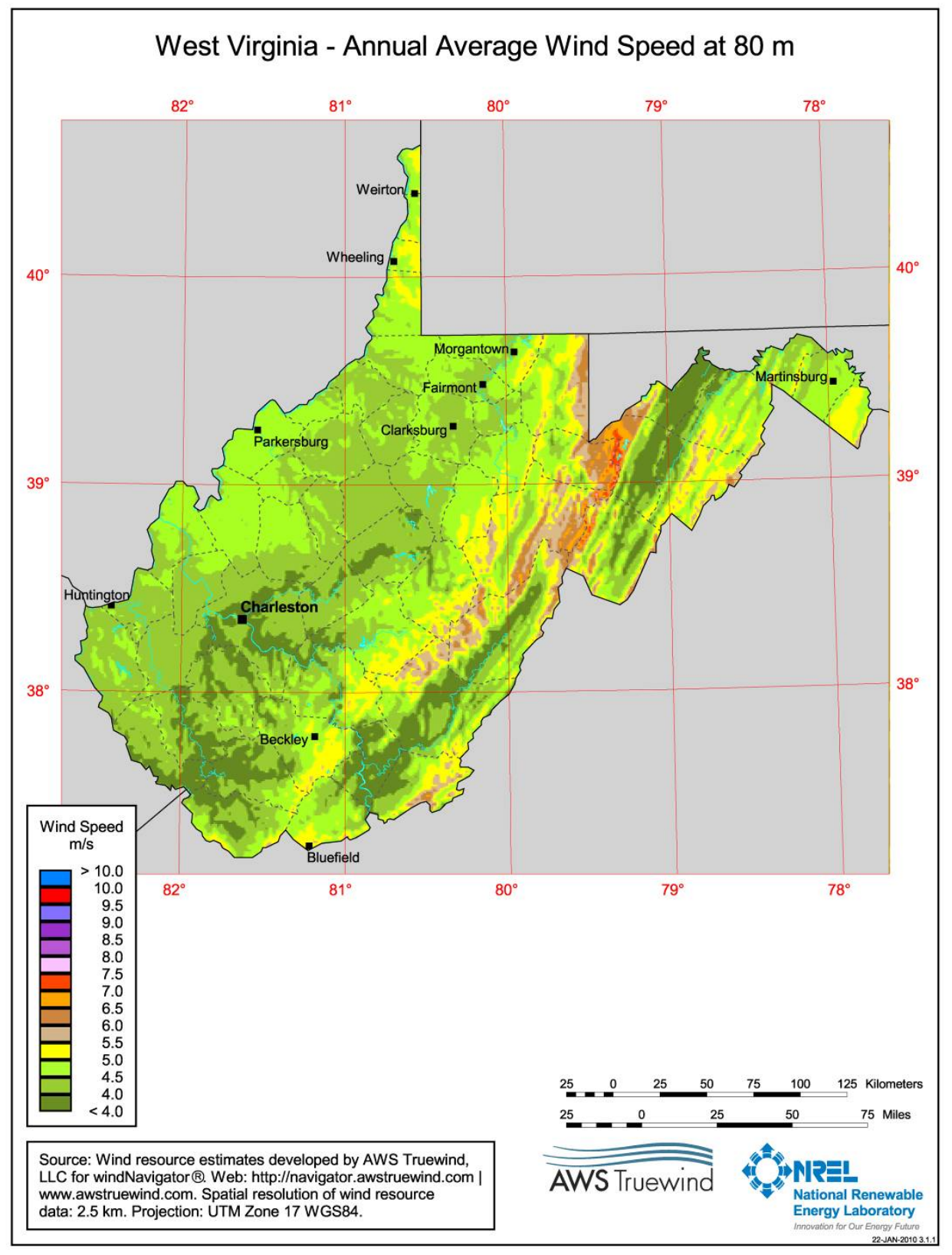

Fig. A.33. West Virginia annual average wind speed at $80 \mathrm{~m}$. (Source: National Renewable Energy Laboratory, 2010) http://www.windpoweringamerica.gov/ images/windmaps/wv_80m.jpg 


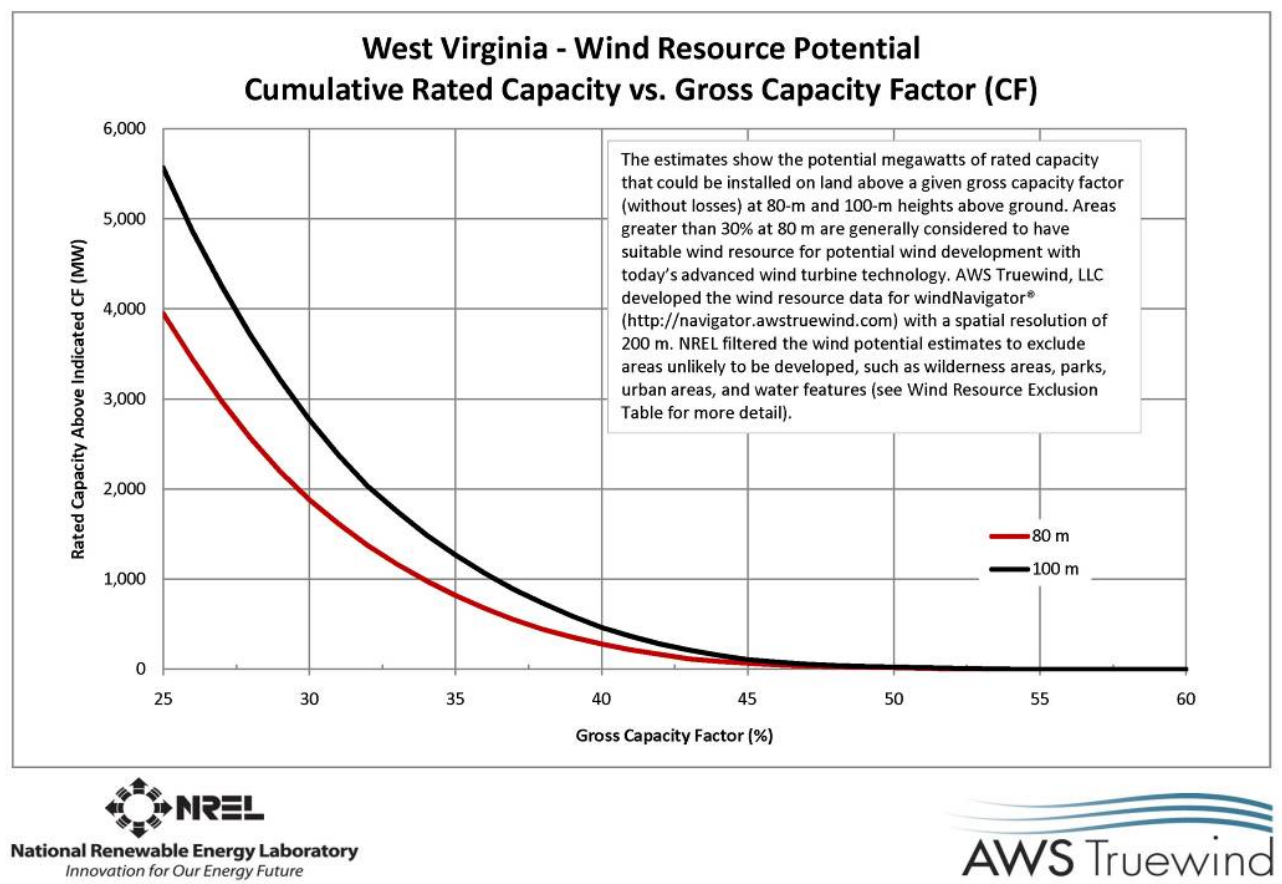

Fig. A.34. West Virginia wind resource potential: Cumulative rated capacity vs gross capacity factor (CF). (Source: NREL, 2010)

\section{A.2 REFERENCES}

EIA. 2009. National Energy Modeling System: An Overview 2009, DOE/EIA-0581, U.S. Department of Energy, Washington, DC, October, http://www.eia.doe.gov/oiaf/aeo/overview/index.html

NREL. 2009. Economic Benefits, Carbon Dioxide $\left(\mathrm{CO}_{2}\right)$ Emissions Reductions and Water Conservation Benefits from 1,000 Megawatts (MW) of New Wind Power in North Carolina, prepared for the Department of Energy,

http://www.windpoweringamerica.gov/pdfs/economic_development/2009/nc_wind_benefits_factsheet.pdf NREL. 2008. Economic Benefits, Carbon Dioxide $\left(\mathrm{CO}_{2}\right)$ Emissions Reductions and Water Conservation Benefits from 1,000 Megawatts (MW) of New Wind Power in Arkansas, prepared for the Department of Energy, http://www.windpoweringamerica.gov/pdfs/economic_development/2008/ ar_wind_benefits_factsheet.pdf 

APPENDIX B.

WIND ENERGY RESOURCES 



\section{APPENDIX B. WIND ENERGY RESOURCES}

\section{B.1 NORTH CAROLINA WIND ENERGY AT APPALACHIAN STATE UNIVERSITY}

The Small Wind Research and Demonstration Site is a unique program that gives first-hand experience with wind power technology. This facility is open to the public to see and hear wind turbines in operation. Tours and workshops are hosted at the facility, which is maintained by Appalachian State University students, faculty, and staff (http://www.wind.appstate.edu/).

\section{B.2 VIRGINIA WIND ENERGY COLLABORATIVE}

The Virginia Wind Energy Collaborative (VWEC) was established to educate the public and inform decision-makers about wind power development in Virginia, in support of the Commonwealth's need for reliable and affordable energy, environmental quality, and economic development (http://vwec.cisat.jmu.edu/).

The Virginia Wind Energy Collaborative supports the balanced development of wind-derived energy in Virginia by providing information and analyses relevant to utility-scale, community-based, and smaller-scale applications. VWEC also provides a forum for collaboration among stakeholders and organizations interested in the benefits and opportunities associated with wind power development in the Commonwealth.

VWEC is supported by the DOE, NREL, and the Virginia Department of Mines, Minerals, and Energy-Energy Division. VWEC facilitates a range of activities and events that serve small businesses, utilities, non-profit organizations, wind developers, consultants, public officials, landowners, environmental organizations, universities, government agencies, and Virginia's communities.

Natural Resources Management \& Development Institute (NRMDI) at Auburn University http://www.nrmdi.auburn.edu/

\section{B.3 MEASUREMENT AND INSTRUMENTATION DATA CENTER (MIDC)}

Oak Ridge Nation Laboratory (ORNL), Tennessee (http://www.nrel.gov/midc/ornl_rsr/), Elizabeth City State University (ECSU), North Carolina (http://www.nrel.gov/midc/ecsu/), and Bluefield State College (BSC), West Virginia (http://www.nrel.gov/midc/bsc/) are involved in Irradiance and Meteorological Data Collection for MIDC at NREL.

\section{B.3.1 Wind Future Expectation}

Major New Technical Report Finds Wind Can Provide 20\% of U.S. Electricity Needs by 2030 http://www.awea.org/newsroom/releases/20percent_Wind_Report_12May2008.html

U.S. Department of Energy analysis finds that wind can be major contributor to energy mix. Wind power is capable of becoming a major contributor to America's electricity supply over the next three decades, according to a report released by the U.S. Department of Energy. The groundbreaking report, 20\% Wind Energy by 2030: Increasing Wind Energy's Contribution to U.S. Electricity Supply, looks closely at one scenario for reaching $20 \%$ wind energy by 2030 and contrasts it to a scenario of no new U.S. wind power capacity.

"DOE's wind report is a thorough look at America's wind resource, its industrial capabilities, and future energy prices, and confirms the viability and commercial maturity of wind as a major contributor to America's energy needs, now and in the future," DOE Assistant Secretary of Energy Efficiency and Renewable Energy Andy Karsner said. "To dramatically reduce greenhouse gas emissions and enhance our energy security, clean power generation at the gigawatt-scale will be necessary and will require us to take a comprehensive approach to scaling renewable wind power, streamlining siting and permitting processes, and expanding the domestic wind manufacturing base." 
Included in the report are examinations of America's technological and manufacturing capabilities, the future costs of energy sources, U.S. wind energy resources, and the environmental and economic impacts of wind development. Under the $20 \%$ wind scenario, installations of new wind power capacity would increase to more than $16,000 \mathrm{MW} /$ year by 2018 and continue at that rate through 2030 .

"The report shows that wind power can provide $20 \%$ of the nation's electricity by 2030 , and be a critical part of the solution to global warming," said AWEA Executive Director Randall Swisher. "This level of wind power is the equivalent of taking 140 million cars off the road," he said. "The report identifies the central constraints to achieving 20\%-transmission, siting, manufacturing, and technology - and demonstrates how each can be overcome. As an inexhaustible domestic resource, wind strengthens our energy security, improves the quality of the air we breathe, slows climate change, and revitalizes rural communities."

The report finds that achieving a $20 \%$ wind contribution to U.S. electricity supply would

- reduce carbon dioxide emissions from electricity generation by 25 percent in 2030;

- reduce natural gas use by $11 \%$;

- reduce water consumption associated with electricity generation by 4 trillion gallons by 2030 ;

- increase annual revenues to local communities to more than $\$ 1.5$ billion by 2030 ; and

- support roughly 500,000 jobs in the United States, with an average of more than 150,000 workers directly employed by the wind industry.

At $20 \%$ of electric power generation, significant growth in the manufacturing supply chain would create jobs and remedy the current shortage in parts for wind turbines. Reducing the use of natural gas could save money for consumers due to the resulting downward pressure on the price of natural gas, according to AWEA.

"We must look at meeting future electric demands in a cost-effective way," said Suedeen Kelly, FERC Commissioner. "The $20 \%$ wind scenario would only cost $2 \%$ more than the cost of the baseline scenario without wind. At 50 cents per month for the average ratepayer, that is a small price to pay for the climate, water, natural gas, and energy security benefits it would buy - and it does not even count the stability provided to consumers by eliminating fuel price risk."

"Though economic and other factors will ultimately determine our energy future, we believe the $20 \%$ wind scenario is feasible but only with a major national transmission highway system. Delivering power from the best windy regions to the growing urban supply requires a bigger, stronger transmission system. Strong regional and interregional planning as well as broad allocation of costs will allow the United States to rely on a broader diversity of generation resources," said Mike Heyeck, Senior VP of AEP Transmission.

The report comes at an important time in wind development. In 2007, wind was one of the fastest growing sources of electricity in the nation, second only to natural gas for the third consecutive year. According to an AWEA report released last week, the U.S. wind energy industry continued new installations at a breakneck pace in the first quarter of 2008, putting 1,400 MW or approximately $\$ 3$ billion worth of new generating capacity in place-enough to serve the equivalent of 400,000 homescoupled with investment in 17 new manufacturing facilities over the past year.

"Wind is an important part of BP Alternative Energy's business and of BP's diverse energy portfolio. Siting and wildlife issues will be a challenge, but AWEA and industry leaders are committed to working with stakeholders to make wind the environmental electricity choice," said Bob Lukefahr, President, Power Americas, BP Alternative Energy North America. "This report underscores the benefits of diversifying our electricity sources. Growing to $20 \%$ wind requires investment in new manufacturing and capital projects, an estimated 500,000 jobs, and brings rural economic development across the country." 


\section{B.4 FUTURE OF OFFSHORE WIND ENERGY IN THE UNITED STATES}

http://www.nrel.gov/docs/fy04osti/36313.pdf

Offshore wind energy development is an unexplored U.S. domestic power resource that is estimated to be economically developable using megawatt-scale wind turbines in large offshore wind farms within a decade. Taking into account significant exclusions for shipping lanes, environmental easements, and viewshed concerns, areas off the coast of the United States, within a $50 \mathrm{~nm}$ limit, contain resources of almost $907 \mathrm{GW}$; an amount greater than current installed U.S. electrical capacity. When additional resources in the Gulf Coast and Great Lakes regions are determined, this number will grow. Much of the offshore wind resource lies close to major urban load centers with high-energy costs, and can be brought to market with minimal new transmission construction.

With $98 \mathrm{GW}$ of this resource located in waters shallower than $30 \mathrm{~m}$, a near-term market is available for the industry to gain experience and mature the technology. This analysis shows that deepwater offshore wind development is practical with a proactive $R \& D$ agenda involving close collaborations between the oil and gas industry, and the offshore wind community. Demonstrations that prove the viability and cost effectiveness of this new technology for large scale offshore applications will be critical to securing financing and insurance in the earlier stages. As the first projects are deployed over the next few years, the permitting process will become better defined and more streamlined to ensure that offshore wind projects are deployed with care and consideration to all ocean stakeholders without adding undue risk.

New wind technology can be developed that could make floating wind turbines economical, at energy costs as low as $\$ 0.051 / \mathrm{kWh}$ in Class 6 winds by 2015 , given sufficient volume production. Though current technologies can be deployed today in shallow water, improvements in wind turbine design and installation methods are essential to minimize the COE and make offshore wind electricity competitive with conventional generation technology.

\section{B.5 THE FUTURE OF WIND POWER}

http://www.telosnet.com/wind/future.html

The cost of energy from larger electrical output wind turbines used in utility-interconnected or wind farm applications has dropped from more than $\$ 1.00 / \mathrm{kWhr}$ in 1978 to under $\$ 0.05 / \mathrm{kWhr}$ in 1998 and is projected to plummet to $\$ 0.025 / \mathrm{kWhr}$ when new large wind plants come on line in 2001 and 2002 . The hardware costs of these wind turbines have dropped below $\$ 800$ per installed kilowatt in the past 5 years, underpricing the capital costs of almost every other type of power plant.

It is difficult to accurately compare the costs of wind plants and fossil fuel plants because the cost drivers are so different. Low installed-cost-per-kilowatt figures for wind turbines are somewhat misleading because of the low capacity factor of wind turbines relative to coal and other fossil-fuel power plants. (Note: "capacity factor" is simply the ratio of actual energy produced by a power plant to the energy that would be produced if it operated at rated capacity for an entire year.) Capacity factors of successful wind farm operations range from 0.20 to 0.35 . These can be compared with factors of more than 0.50 for fossil-fuel power plants and over 0.60 for some of the new gas turbines.

However, the use of "capacity factor" is also misleading because wind has a "rubber" capacity factor that varies with the density of the wind resource, but that wind resource is constant for the life of the machine and is not subject to manipulation or cost increases. One reason why fossil fuels are so popular with investors is that many of the risks are passed on to consumers. Fossil fuel shortages result in an increase in revenues for investors, who are actually rewarded for (1) speeding the depletion of a nonrenewable resource or (2) not investing enough of their profits in support infrastructure, which (as we have seen in 2000-2001) drives up prices. If a big oil coal or gas company could start charging for the wind, they would make sure that wind power development happened. In late 1996, with the purchase of Zond Systems by Enron (a now-defunct gas mining and distribution company), the possibility of this happening became very real. (Even though Enron proved to be a poor steward for the Zond technology, 
the subsequent purchase of what was one of the only viable Enron divisions by GE Energy in 2003 maintained U.S. visibility in the large wind turbine market.)

In the near future, wind energy will be the most cost-effective source of electrical power. In fact, a good case can be made for saying that it already has achieved this status. The actual life cycle cost of fossil fuels (from mining and extraction to transport to use technology to environmental impact to political costs and impacts, etc.) is not really known, but it is certainly far more than the current wholesale rates. The eventual depletion of these energy sources will entail rapid escalations in price, whichaveraged over the brief period of their use - will result in postponed actual costs that would be unacceptable by present standards. And this does not even consider the environmental and political costs of fossil fuels use that are silently and not so silently mounting every day.

The major technology developments enabling wind power commercialization have already been made. There will be infinite refinements and improvements, of course. One can guess (based on experience with other technologies) that the eventual push to full commercialization and deployment of the technology will happen in a manner that no one can imagine today. There will be a "weather change" in the marketplace or a "killer application" somewhere that will put several key companies or financial organizations in a position to profit. They will take advantage of public interest, the political and economic climate, and emotional or marketing factors to position wind energy technology (developed in a long lineage from the Chinese and the Persians to the present wind energy researchers and developers) for its next round of development. 
APPENDIX C.

SOLAR MANUFACTURING IN SOUTHEAST 



\section{APPENDIX C. SOLAR MANUFACTURING IN SOUTHEAST}

Listed below are manufacturers with facilities in the in the Southeast as of 2008. The numbers may have increased, and there are rumors of an excess in solar manufacturing capability which could reduce costs in the short run at the cost of manufacturing capability in the long run.

Table C.1. Solar manufacturing in Southeast (Ecobusiness Links)

\begin{tabular}{|c|c|c|}
\hline Company & Location/headquarters & Products \\
\hline $\begin{array}{l}\text { GreenBrilliance } \\
\text { http://www.greenbrilliance.com/ }\end{array}$ & Herndon, VA & Solar PV Panels \\
\hline $\begin{array}{l}\text { Suniva } \\
\text { http://www.suniva.com/index.php }\end{array}$ & Norcross, GA & Polysilicon solar cells \\
\hline $\begin{array}{l}\text { United Solar Ovonic LLC } \\
\text { http://www.ovonic.com/index.cfm }\end{array}$ & Auburn Hills, MI & Thin-film solar laminates \\
\hline $\begin{array}{l}\text { Semprius } \\
\mathrm{http} / / / \mathrm{www} \cdot \text { semprius.com/index.htm }\end{array}$ & Durham, NC & $\begin{array}{l}\text { Concentrator photovoltaic (CPV) } \\
\text { modules for large-scale solar } \\
\text { power generation }\end{array}$ \\
\hline $\begin{array}{l}\text { Solargenix Energy, LLC } \\
\text { http://www.solargenix.com/index.cfm }\end{array}$ & Sanford, NC & $\begin{array}{l}\text { Turnkey solar thermal or solar } \\
\text { hybrid systems }\end{array}$ \\
\hline $\begin{array}{l}\text { Alternative Energy Technologies, LLC } \\
\text { http://www.aetsolar.com/index.html }\end{array}$ & Jacksonville, FL & $\begin{array}{l}\text { Solar water heating } \\
\text { PV modules } \\
\text { Solar heating pools }\end{array}$ \\
\hline $\begin{array}{l}\text { Sun-Dome Tubular Skylights } \\
\text { http://www.sun-dome.com/index.html }\end{array}$ & Riviera Beach, FL & $\begin{array}{l}\text { Commercial and residential } \\
\text { tubular skylight products }\end{array}$ \\
\hline $\begin{array}{l}\text { Sun-Tek Manufacturing, Inc. } \\
\text { http://www.sun-tek.com/ }\end{array}$ & Orlando, FL & Tubular skylight \\
\hline $\begin{array}{l}\text { Velux SunTunnels } \\
\text { http://www.veluxusa.com/ }\end{array}$ & Greenwood, SC & Tubular skylight \\
\hline
\end{tabular}



APPENDIX D.

SOLAR ENERGY MARKET AND RESOURCE CENTERS IN THE SOUTHEAST (NREL SOLAR CALCULATORS) 



\section{APPENDIX D. SOLAR ENERGY MARKET AND RESOURCE CENTERS IN THE SOUTHEAST (NREL SOLAR CALCULATORS)}

PVWATTS is developed by the researchers at the NREL to permit non-experts to quickly obtain performance estimates for grid-connected PV systems. The solar energy values of some of the cities in the Southeast are shown as follows. Table D.1 gives the parameters that were used in the calculations for all the cities in Table D.2.

Table D.1. Parameter used for calculations in Table D.2

\begin{tabular}{cccccc}
\hline $\begin{array}{c}\text { DC rating } \\
(\mathbf{k W})\end{array}$ & $\begin{array}{c}\text { DC to AC } \\
\text { derate factor }\end{array}$ & Array type & $\begin{array}{c}\text { Array tilt } \\
\text { (degree) }\end{array}$ & $\begin{array}{c}\text { Array } \\
\text { azimuth } \\
\text { (degree) }\end{array}$ & $\begin{array}{c}\text { Cost of } \\
\text { electricity } \\
(\mathbf{c} / \mathbf{k W h r})\end{array}$ \\
\hline 4.0 & 0.77 & Fixed tilt & Latitude & 180 (south) & State average \\
\hline
\end{tabular}

Table D.2. Solar energy values in different Southeast cities

\begin{tabular}{|c|c|c|c|c|c|c|c|}
\hline City & $\begin{array}{l}\text { Latitude and } \\
\text { longitude } \\
\text { (degree) }\end{array}$ & $\begin{array}{l}\text { Elevation } \\
\text { (m) }\end{array}$ & $\begin{array}{c}\text { Array } \\
\text { Tilt } \\
\text { (degree) }\end{array}$ & $\begin{array}{c}\text { Cost of } \\
\text { electricity } \\
(\mathbf{c} / \mathbf{k W h r})\end{array}$ & $\begin{array}{l}\text { Annual average } \\
\text { solar radiation } \\
\left(\mathrm{kWhr} / \mathrm{m}^{2} / \mathrm{day}\right)\end{array}$ & $\begin{array}{l}\text { Annual } \\
\text { AC } \\
\text { energy } \\
\text { (kWhr) }\end{array}$ & $\begin{array}{c}\text { Annual } \\
\text { energy } \\
\text { value } \\
(\$)\end{array}$ \\
\hline Huntsville, AL & $\begin{array}{l}34.65^{\circ} \mathrm{N} \\
86.77^{\circ} \mathrm{W}\end{array}$ & 190 & 34.7 & 7.6 & 4.94 & 5129 & 389.80 \\
\hline Birmingham, AL & $\begin{array}{l}33.57^{\circ} \mathrm{N} \\
86.75^{\circ} \mathrm{W}\end{array}$ & 192 & 33.6 & 7.6 & 5.00 & 5157 & 391.93 \\
\hline Montgomery, AL & $\begin{array}{l}32.30^{\circ} \mathrm{N} \\
86.40^{\circ} \mathrm{W}\end{array}$ & 62 & 32.3 & 7.6 & 5.10 & 5205 & 395.58 \\
\hline Mobile, AL & $\begin{array}{l}30.68^{\circ} \mathrm{N} \\
88.25^{\circ} \mathrm{W}\end{array}$ & 67 & 30.7 & 7.6 & 4.85 & 4959 & 376.88 \\
\hline Fort Smith, AR & $\begin{array}{l}35.33^{\circ} \mathrm{N} \\
94.37^{\circ} \mathrm{W}\end{array}$ & 141 & 35.3 & 7.4 & 5.16 & 5324 & 393.98 \\
\hline Little Rock, AR & $\begin{array}{c}34.73^{\circ} \mathrm{N} \\
92.23^{\circ} \mathrm{W}\end{array}$ & 81 & 34.8 & 7.4 & 5.05 & 5187 & 383.84 \\
\hline Tallahassee, FL & $\begin{array}{l}30.38^{\circ} \mathrm{N} \\
84.37^{\circ} \mathrm{W}\end{array}$ & 21 & 30.4 & 9.0 & 5.16 & 5257 & 473.13 \\
\hline Jacksonville, FL & $\begin{array}{l}30.50^{\circ} \mathrm{N} \\
81.70^{\circ} \mathrm{W}\end{array}$ & 9 & 30.5 & 9.0 & 5.04 & 5142 & 462.78 \\
\hline Daytona Beach, FL & $\begin{array}{l}29.18^{\circ} \mathrm{N} \\
81.05^{\circ} \mathrm{W}\end{array}$ & 12 & 29.2 & 9.0 & 5.30 & 5435 & 489.15 \\
\hline Tampa, FL & $\begin{array}{l}27.97^{\circ} \mathrm{N} \\
82.53^{\circ} \mathrm{W}\end{array}$ & 3 & 28 & 9.0 & 5.37 & 5455 & 490.95 \\
\hline West Palm Beach, FL & $\begin{array}{l}26.68^{\circ} \mathrm{N} \\
80.10^{\circ} \mathrm{W}\end{array}$ & 6 & 26.7 & 9.0 & 5.13 & 5229 & 470.61 \\
\hline Miami, FL & $\begin{array}{l}25.80^{\circ} \mathrm{N} \\
80.27^{\circ} \mathrm{W}\end{array}$ & 2 & 25.8 & 9.0 & 5.26 & 5357 & 482.13 \\
\hline Key West, FL & $\begin{array}{l}24.55^{\circ} \mathrm{N} \\
81.75^{\circ} \mathrm{W}\end{array}$ & 1 & 24.6 & 9.0 & 5.55 & 5656 & 509.04 \\
\hline Athens, GA & $\begin{array}{l}33.95^{\circ} \mathrm{N} \\
83.32^{\circ} \mathrm{W}\end{array}$ & 244 & 34 & 7.9 & 5.11 & 5286 & 417.59 \\
\hline Atlanta, GA & $\begin{array}{l}33.65^{\circ} \mathrm{N} \\
84.43^{\circ} \mathrm{W}\end{array}$ & 315 & 33.6 & 7.9 & 5.18 & 5381 & 425.10 \\
\hline
\end{tabular}


Table D.2. (continued)

\begin{tabular}{|c|c|c|c|c|c|c|c|}
\hline City & $\begin{array}{l}\text { Latitude and } \\
\text { longitude } \\
\text { (degree) }\end{array}$ & $\begin{array}{c}\text { Elevation } \\
\text { (m) }\end{array}$ & $\begin{array}{c}\text { Array } \\
\text { Tilt } \\
\text { (degree) }\end{array}$ & $\begin{array}{c}\text { Cost of } \\
\text { electricity } \\
(\mathbf{c} / \mathbf{k W h r})\end{array}$ & $\begin{array}{c}\text { Annual average } \\
\text { solar radiation } \\
\left(\mathrm{kWhr} / \mathrm{m}^{2} / \mathrm{day}\right)\end{array}$ & $\begin{array}{c}\text { Annual } \\
\text { AC } \\
\text { energy } \\
\text { (kWhr) }\end{array}$ & $\begin{array}{c}\text { Annual } \\
\text { energy } \\
\text { value } \\
\text { (\$) }\end{array}$ \\
\hline Augusta, GA & $\begin{array}{l}33.37^{\circ} \mathrm{N} \\
81.97^{\circ} \mathrm{W}\end{array}$ & 45 & 33.4 & 7.9 & 5.05 & 5210 & 411.59 \\
\hline Macon, GA & $\begin{array}{l}32.70^{\circ} \mathrm{N} \\
83.65^{\circ} \mathrm{W}\end{array}$ & 110 & 32.7 & 7.9 & 5.06 & 5179 & 409.14 \\
\hline Columbus, GA & $\begin{array}{l}32.52^{\circ} \mathrm{N} \\
84.95^{\circ} \mathrm{W}\end{array}$ & 136 & 32.5 & 7.9 & 5.09 & 5221 & 412.46 \\
\hline Savannah, GA & $\begin{array}{l}32.13^{\circ} \mathrm{N} \\
81.20^{\circ} \mathrm{W}\end{array}$ & 16 & 32.1 & 7.9 & 5.15 & 5304 & 419.02 \\
\hline Covington, $\mathrm{KY}$ & $\begin{array}{l}39.07^{\circ} \mathrm{N} \\
84.67^{\circ} \mathrm{W}\end{array}$ & 271 & 39.1 & 6.1 & 4.49 & 4725 & 288.23 \\
\hline Louisville, KY & $\begin{array}{l}38.18^{\circ} \mathrm{N} \\
85.73^{\circ} \mathrm{W}\end{array}$ & 149 & 38.2 & 6.1 & 4.71 & 4923 & 300.30 \\
\hline Lexington, $\mathrm{KY}$ & $\begin{array}{l}38.03^{\circ} \mathrm{N} \\
84.60^{\circ} \mathrm{W}\end{array}$ & 301 & 38.0 & 6.1 & 4.54 & 4793 & 292.37 \\
\hline Shreveport, LA & $\begin{array}{l}32.47^{\circ} \mathrm{N} \\
93.82^{\circ} \mathrm{W}\end{array}$ & 79 & 32.5 & 8.1 & 5.06 & 5177 & 419.34 \\
\hline Baton Rouge, LA & $\begin{array}{l}30.53^{\circ} \mathrm{N} \\
91.15^{\circ} \mathrm{W}\end{array}$ & 23 & 30.5 & 8.1 & 4.94 & 5015 & 406.22 \\
\hline Lake Charles, LA & $\begin{array}{l}30.12^{\circ} \mathrm{N} \\
93.22^{\circ} \mathrm{W}\end{array}$ & 3 & 30.1 & 8.1 & 5.03 & 5136 & 416.02 \\
\hline New Orleans, LA & $\begin{array}{l}29.98^{\circ} \mathrm{N} \\
90.25^{\circ} \mathrm{W}\end{array}$ & 3 & 30.0 & 8.1 & 5.02 & 5109 & 413.83 \\
\hline Jackson, MI & $\begin{array}{l}32.32^{\circ} \mathrm{N} \\
90.08^{\circ} \mathrm{W}\end{array}$ & 101 & 32.3 & 8.2 & 5.05 & 5165 & 423.53 \\
\hline Meridian, MI & $\begin{array}{l}32.33^{\circ} \mathrm{N} \\
88.75^{\circ} \mathrm{W}\end{array}$ & 94 & 32.3 & 8.2 & 4.99 & 5094 & 417.71 \\
\hline Asheville, NC & $\begin{array}{l}35.43^{\circ} \mathrm{N} \\
82.53^{\circ} \mathrm{W}\end{array}$ & 661 & 35.4 & 8.5 & 4.89 & 5167 & 439.19 \\
\hline Greensboro, NC & $\begin{array}{c}36.08^{\circ} \mathrm{N} \\
79.95^{\circ} \mathrm{W}\end{array}$ & 270 & 36.1 & 8.5 & 5.02 & 5248 & 446.08 \\
\hline Charlotte, NC & $\begin{array}{l}35.22^{\circ} \mathrm{N} \\
80.93^{\circ} \mathrm{W}\end{array}$ & 234 & 35.2 & 8.5 & 5.07 & 5272 & 448.12 \\
\hline Raleigh, NC & $\begin{array}{l}35.87^{\circ} \mathrm{N} \\
78.78^{\circ} \mathrm{W}\end{array}$ & 134 & 35.9 & 8.5 & 5.09 & 5249 & 446.17 \\
\hline Cape Hatteras, NC & $\begin{array}{l}35.27^{\circ} \mathrm{N} \\
75.55^{\circ} \mathrm{W}\end{array}$ & 2 & 35.3 & 8.5 & 5.05 & 5294 & 449.99 \\
\hline Wilmington, NC & $\begin{array}{c}34.27^{\circ} \mathrm{N} \\
77.90^{\circ} \mathrm{W}\end{array}$ & 9 & 34.3 & 8.5 & 5.02 & 5202 & 442.17 \\
\hline Greenville, SC & $34.90^{\circ} \mathrm{N}$ & 296 & 34.9 & 8.1 & 5.09 & 5272 & 427.03 \\
\hline Columbia, SC & $\begin{array}{l}33.95^{\circ} \mathrm{N} \\
81.12^{\circ} \mathrm{W}\end{array}$ & 69 & 34.0 & 8.1 & 5.10 & 5240 & 424.44 \\
\hline Charleston, SC & $\begin{array}{l}32.90^{\circ} \mathrm{N} \\
80.03^{\circ} \mathrm{W}\end{array}$ & 12 & 32.9 & 8.1 & 5.16 & 5344 & 432.86 \\
\hline Memphis, TN & $\begin{array}{l}35.05^{\circ} \mathrm{N} \\
89.98^{\circ} \mathrm{W}\end{array}$ & 87 & 35.1 & 6.9 & 5.18 & 5352 & 369.29 \\
\hline Nashville, TN & $\begin{array}{l}36.12^{\circ} \mathrm{N} \\
86.68^{\circ} \mathrm{W}\end{array}$ & 180 & 36.1 & 6.9 & 4.93 & 5110 & 352.59 \\
\hline
\end{tabular}


Table D.2. (continued)

\begin{tabular}{|c|c|c|c|c|c|c|c|}
\hline City & $\begin{array}{c}\text { Latitude and } \\
\text { longitude } \\
\text { (degree) }\end{array}$ & $\begin{array}{c}\text { Elevation } \\
\text { (m) }\end{array}$ & $\begin{array}{c}\text { Array } \\
\text { Tilt } \\
\text { (degree) }\end{array}$ & $\begin{array}{c}\text { Cost of } \\
\text { electricity } \\
(\mathbf{c} / \mathbf{k W h r})\end{array}$ & $\begin{array}{l}\text { Annual average } \\
\text { solar radiation } \\
\left(\mathrm{kWhr} / \mathrm{m}^{2} / \mathrm{day}\right)\end{array}$ & $\begin{array}{c}\text { Annual } \\
\text { AC } \\
\text { energy } \\
\text { (kWhr) }\end{array}$ & $\begin{array}{c}\text { Annual } \\
\text { energy } \\
\text { value } \\
(\$)\end{array}$ \\
\hline Chattanooga, TN & $\begin{array}{l}35.03^{\circ} \mathrm{N} \\
85.20^{\circ} \mathrm{W}\end{array}$ & 210 & 35.0 & 6.9 & 4.79 & 4936 & 340.58 \\
\hline Bristol, TN & $\begin{array}{l}36.48^{\circ} \mathrm{N} \\
82.40^{\circ} \mathrm{W}\end{array}$ & 459 & 36.5 & 6.9 & 4.58 & 4761 & 328.51 \\
\hline Knoxville, TN & $\begin{array}{l}35.82^{\circ} \mathrm{N} \\
83.98^{\circ} \mathrm{W}\end{array}$ & 299 & 35.8 & 6.9 & 4.66 & 4821 & 332.65 \\
\hline Roanoke, VA & $\begin{array}{l}37.32^{\circ} \mathrm{N} \\
79.97^{\circ} \mathrm{W}\end{array}$ & 358 & 37.3 & 8.0 & 4.83 & 5090 & 407.20 \\
\hline Lynchburg, VA & $\begin{array}{l}37.33^{\circ} \mathrm{N} \\
79.20^{\circ} \mathrm{W}\end{array}$ & 279 & 37.3 & 8.0 & 5.09 & 5344 & 427.52 \\
\hline Sterling, VA & $\begin{array}{l}38.95^{\circ} \mathrm{N} \\
77.45^{\circ} \mathrm{W}\end{array}$ & 82 & 39.0 & 8.0 & 4.68 & 4928 & 394.24 \\
\hline Richmond, VA & $\begin{array}{l}37.50^{\circ} \mathrm{N} \\
77.33^{\circ} \mathrm{W}\end{array}$ & 50 & 37.5 & 8.0 & 4.83 & 5063 & 405.04 \\
\hline Norfolk, VA & $\begin{array}{l}36.90^{\circ} \mathrm{N} \\
76.20^{\circ} \mathrm{W}\end{array}$ & 9 & 36.9 & 8.0 & 4.84 & 5085 & 406.80 \\
\hline Huntington, WV & $\begin{array}{l}38.37^{\circ} \mathrm{N} \\
82.55^{\circ} \mathrm{W}\end{array}$ & 255 & 38.4 & 6.2 & 4.43 & 4643 & 287.87 \\
\hline Charleston, WV & $\begin{array}{l}38.37^{\circ} \mathrm{N} \\
81.60^{\circ} \mathrm{W}\end{array}$ & 290 & 38.4 & 6.2 & 4.35 & 4527 & 280.67 \\
\hline Elkins, WV & $\begin{array}{l}38.88^{\circ} \mathrm{N} \\
79.85^{\circ} \mathrm{W}\end{array}$ & 594 & 38.9 & 6.2 & 4.15 & 4394 & 272.43 \\
\hline
\end{tabular}

\section{D.1 SOLAR ENERGY RESOURCE CENTERS IN THE SOUTHEAST}

Natural Resources Management \& Development Institute (NRMDI) at Auburn University (Auburn NRMDI)

\section{D.1.1 Measurement and Instrumentation Data Center (MIDC)}

Oak Ridge Nation Laboratory (ORNL), TN (http://www.nrel.gov/midc/ornl_rsr/), Elizabeth City State University (ECSU), NC (http://www.nrel.gov/midc/ecsu/), and Bluefield State College (BSC), West Virginia (http://www.nrel.gov/midc/bsc/) are involved in Irradiance and Meteorological Data Collection for MIDC at NREL.

\section{D.1.2 North Carolina Solar Center at North Carolina State University (NCSC at NCSU)}

The North Carolina Solar Center began in 1981 with the creation of a solar house built to research and to demonstrate the benefits of passive solar, solar water heating, and solar electricity. With a full-time staff of over 30 people, they cover all renewable energy areas including wind and biomass. The North Carolina Solar Center has been involved with dozens of technical research projects throughout the state. Included are PV projects, solar thermal projects, and building science projects. 


\section{D.1.3 Florida Solar Energy Center at the University of Central Florida (FSEC at UCF)}

The Photovoltaics and Distributed Generation Division seeks to provide the general public and professionals with accurate and current information about alternative energy use and production. In recent years, this division has expanded its scope to include distributed generation technologies such as microturbines.

A core part of the PV work being conducted by FSEC, includes the testing and certification of PV components and systems. For components and systems used as part of state or federally funded projects, this certification is crucial. To the citizens of Florida, the testing and certification program is an important way to ensure quality and a competitive market for solar products in the state. For additional information on these services or to have a product certified, visit the PV Module and PV System testing and certification pages.

As one of the founding research programs at the FSEC, the solar thermal department has a long history of research that ranges from commercial system design to low-cost solar ovens for third-world countries. 